
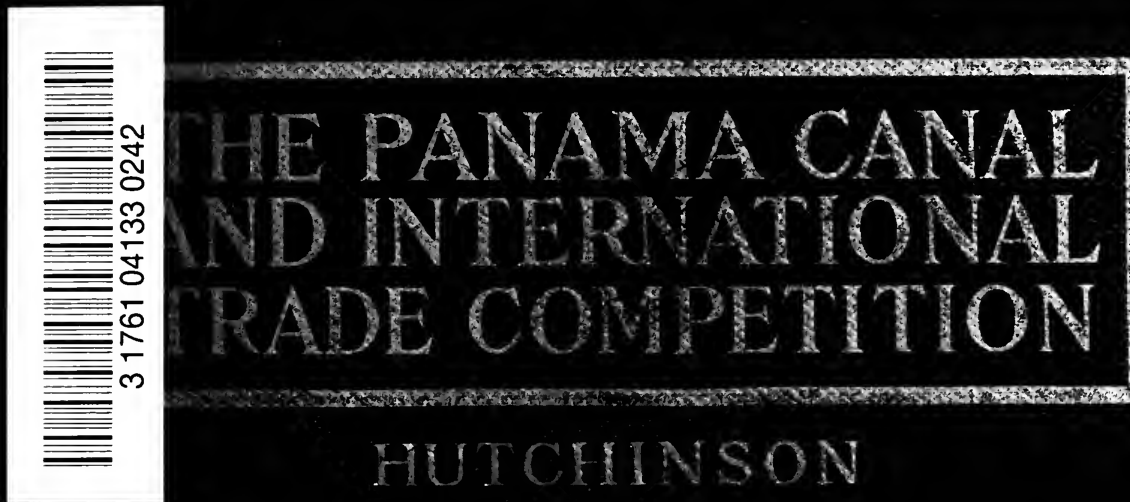

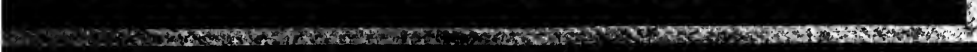

HUTCHINSON 

$+$ 

THE PANAMA CANAL AND INTERNATIONAL TRADE COMPETITION 


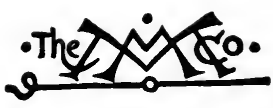

THE MACMILLAN COMPANY

NEW YORK - BOSTON - CHICAGO - DALIAS

ATLANTA - SAN TRANCISCO

MACMILLAN \& CO., LnMted

LONDON - BOMBAY - CAICUTTA

MELBOURNR

THE MACMULLAN CO. OF CANADA, Lm. Torosro 
H9766p

\title{
THE PANAMA CANAL AND INTERNATIONAL TRADE COMPETITION
}

\author{
BY \\ LINCOLN HUTCHINSON \\ ONIVERSITY OF CALIFORNIA
}

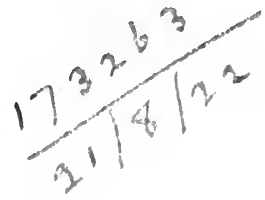

2Nom Unak

THE MACMIILAN COMPANY

I9I5

All rights reserved 
Copyriarr, 1915

BY THE MACMIILAN COMPANY

Set up and electrotyped. Published January, rgrs. 
TO MY FATHER 


\section{Digitized by the Internet Archive in 2007 with funding from Microsoft Corporation}




\section{PREFACE}

IN preparing the following chapters on the Panama Canal and international trade competition, the author has made no attempt to present a complete compendium of facts relating to the commercial intercourse between the two great regions which the canal will connect. The great movements in international trade result not so much from the successive seizing of new opportunities to supply the demand for this or that commodity in which the trader deals as from the operation of economic forces which make two or more economically different regions mutually dependent upon one another. The roots of large trade movement lie in diversity of resources and differences in stage of economic growth; the understanding of its possibilities and the recognition of its opportunities rest upon a group of factors which lie in the field of economic geography. Throughout the following pages the attempt has been made to place the emphasis upon those economic-geographic factors which render the Atlantic and the Pacific countries economically interdependent and hence tend to produce commercial interchange between them. The author has sought to avoid the mistake either of too precise prediction as to what trade development must take place or of presuming to instruct practical busivii 
ness men as to the precise methods which they should employ in the conduct of their businesses. American business men have on the whole shown themselves well able to handle the problems which have confronted them. Yet there are certain fundamental movements and forces which are sometimes easily overlooked unless one's attention is particularly directed towards them, the losing sight of which may lead to the waste of a good deal of useless effort; and the attempt is here made to indicate clearly what these basic movements, forces and tendencies are. The traders or the trading nations which most readily and quickly put themselves in line with forces already operating are the ones which will be the most likely to accomplish permanent results.

The object of this book, therefore, is not to give mere information or to present a mass of facts but to use the material gathered for the purpose of illustrating tendencies. It is hoped that such a presentation may prove to be suggestive to business men who have or may have dealings with the countries in question or are interested in forming some opinion concerning the possible or probable commercial influence of the new canal. At the same time, the discussion of the problem may not be void of interest to the general reader or the student of commercial or economic history or geography. The business man who looks through the following pages with a view to getting specific information concerning some particular line of trade in which he may be interested will probably meet with disappointment, but he may nevertheless be able to find suggestions which, 
in the light of his fuller practical experience in the business world he may expand and make use of.

The materials for the book have been gathered through a series of years during which the author has made a study of the commercial problems of Latin-America and the Pacific Ocean countries generally. The statistics used have been compiled from official sources for all of the countries which publish such data. Most of the facts and statements of a more general nature are based upon the writer's personal observations in the course of a series of visits to all of the countries mentioned and conversations with men actively engaged in commercial dealings in those countries. In the chapter on the effect of the canal on trade routes the report of the Isthmian Canal Commission on Panama Traffic and Tolls by Professor E. R. Johnson, has been extensively drawn upon; and here and there use has been made of articles and reports previously published by the present writer. Among these latter are: Trade Conditions in South and Central America, Washington, I906-07; The Panama Canal and Foreign Trade Competition, Daily Consular and Trade Reports, January, I9I3; The Panama Canal and Competition for Trade in Latin America, the Orient, and Australasia, Journal of the Royal Statistical Society, London, March, I9I3; New Opportunities in the Pacific, Yale Review, July, I9I4; Voyage Costs via Panama and other Routes, American Economic Review, September, I9I4. The author also takes this occasion to express his appreciation of the courteous and efficient assistance rendered him by the American and other consular and diplo- 
matic officers in the various countries visited by him in the prosecution of this work and to friends at home who have given aid in the form of suggestive criticism.

\section{LiNCOLN HUTCHENSON.}

Berkeley, Caltrornia, June, IgI4. 


\section{CONTENTS}

CHAPTER
PAGE

I. Introduction . . . . . . . . . . . . . . . . .

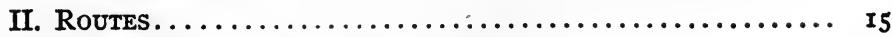

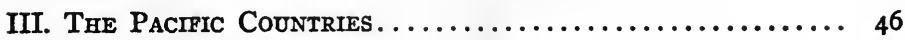

IV. The Atlantic Codntries................... 70

V. Recent Trade Movement.................... 98

VI. Classes of Exports to the Pacific Countries......... 132

VII. Details of Exports to the Pacific Countries.......... I55

VIII. DetaIls of Imports from the PactFic CoUntries........ 2 I5

IX. Conclusion............................ 24I

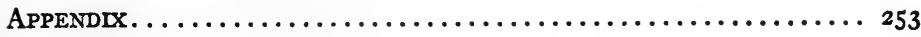

$\operatorname{INDEX} \ldots \ldots \ldots \ldots \ldots \ldots \ldots \ldots \ldots \ldots \ldots \ldots \ldots \ldots \ldots \ldots \ldots \ldots{ }_{26}$ 

THE PANAMA CANAL AND INTERNATIONAL TRADE COMPETITION 



\section{THE PANAMA CANAL AND INTERNATIONAL TRADE COMPETITION}

\section{CHAPTER I}

INTRODUCTION

Ever since Balboa's discovery that only a narrow strip of land blocked the passage from the Atlantic to the Pacific the traders of the world have looked forward to a time when this obstruction would be removed. The goal of the mediæval merchant's ambition was the fabulously wealthy East. The only routes thither in the sixteenth century were either overland through Asia, or by the long and hazardous sea voyage via Cape Horn or the Cape of Good Hope. The Asiatic route was infested by the Turks: the voyage around Africa was beset by serious perils of storm and Arab pirates: the route via Magellan or Cape Horn presented the handicap of enormously increased distance. The knowledge that a mere forty-mile land barrier at Panama was the only obstacle to a shorter and safer passage to the Eastern treasure house, inevitably prompted men to dream of its removal.

For three centuries and more this hope has lived, but the demand for its fulfillment has been subject to many varia- 
tions in intensity. The need for such a route has on the whole grown less pressing as the world has passed from the mediæval to the modern stage of commercial activity. The economic growth of the countries of western Europe and the settlement and development of the resources of America gradually converted the Atlantic Ocean basin into the greatest commercial area in the world's history. The trade of the Orient, though its value, in absolute amount, was steadily increasing, was relatively of much less moment than during the days of da Gama and Albuquerque. European commerce with Asia and the Indies still longed for a better route than those which existed but the appeal was vastly less general.

Then came de Lesseps' triumph at Suez. European commerce found its easier outlet to the East, and to Europe, at least, the value of a western gateway to the Pacific became even less significant.

This was true, however, only for a short time. During the last quarter of the nineteenth century several new factors made their appearance in the world of international trade and turned men's thoughts again toward the desirability of a more direct communication between the Atlantic and the Pacific. The United States, which until that time had been chiefly an exporter of raw materials and foodstuffs and had not competed seriously with Europe in the sale of manufactured articles, rapidly rose to prominence as an exporter of the latter class of goods. Several of the larger countries of South America, through greater political stability and greater attention to the development of in- 
dustries and resources, rose from their former insignificance as traders and lent new importance to the Pacific as well as to the Atlantic littoral of that continent. A great industrial revolution in Japan, predictions of similar developments in China, American enterprise in the Philippines, increasing population and the exploitation of new resources in Alaska, British Columbia, Australia, New Zealand, and even in Mexico and Central America, gave a new significance to the Pacific Ocean not as a mere route to the Indies, but as a trade area on its own account. The conception of the Isthmus of Panama as a barrier naturally came into prominence once more.

To the United States this aspect of the Isthmus as a barrier, appealed with greatest force. The geographic relations between her great trade centers and the Pacific markets were such as at first sight to make the cutting of the canal seem to offer her greater opportunities in the Pacific than to any European nation. The deeply-rooted conviction of American merchants carrying on trade between the Atlantic and Pacific coasts of the United States itself that they were helplessly the prey of the trans-continental railway freight rate makers added to the demand for a short sea route. And what was coming to be regarded as an economic necessity was suddenly raised to the position of a military necessity as well, by the Spanish war and the spectacular voyage of the "Oregon."

To Americans, then, for the reasons just mentioned, the opening of the Panama Canal appeals as an event of the utmost importance. To Europeans, on the other hand, 
the significance is not thought to be so great; their largest trade interests in the Pacific are already cared for by the Suez or the Cape of Good Hope route. Yet even to them, with the increasing importance of the West Coast of South America, of Central America and Mexico, of the Pacific Coasts of the United States, British North America and Alaska, the facilities offered by the new route must appeal with considerable force. At any rate, whether directly interested or not, their fortunes are seen to be rather deeply concerned, indirectly, through the increased facilities which will be offered to their great new competitor, the United States. It is safe to say that the commercial world as a whole believes in the canal as a potent factor in international trade competition. In America there is a certain tendency to exaggerate its importance; in Europe a certain skepticism as to the extent of its influence; but in general a belief that its completion will have important results. Predictions as to what these results will be would be of great interest to statesmen and of immense value to merchants; and many attempts to forecast the future have been and are being made. These have resulted in so many widely differing and often diametrically opposed opinions that one is tempted to despair of any real solution; yet surely, so profound a geographical change as the cutting of a passage between the Atlantic and Pacific Ocean basins, through a barrier which in extreme north and south length stretches over 6,000 or 7,000 miles, must have some results which we ought to be able to foresee. The differences of opinion may merely be the outcome of too hasty generalization, on the 
one hand, and an exaggerated attention to details, on the other. When the enthusiast makes sweeping statements as to results it is so easy for the specialist to discover glaring exceptions that the whole conclusion becomes discredited.

Much confusion seems to have resulted from our having fallen into the use of a figure of speech. We use the phrasethe canal will "create" a new line of traffic-the cutting of the Isthmus will "do" certain things; forgetting that the canal will be a purely passive factor in the problem and will really "do" nothing at all. Foreign trade, like all trade, is an affair of individuals or groups of individuals, actuated by self-interest, seeking profit by exchanging goods. The motive power lies with the traders of the various countries of the Atlantic and Pacific Ocean basins. The canal will merely open to some of these persons opportunities which did not formerly exist. Whether or not it will open an opportunity to any specified person will depend on many considerations. The canal will be used in any particular trade only if it offers a chance for additional profit to some particular trader or traders. The forces producing trade between Atlantic and Pacific countries already exist and operate: the canal may or may not, in any particular case, offer new facilities for the operation of these forces. The study of the probable results of the opening of the new route becomes an analysis of these causes and the relation between them and the new opportunity.

Foreign trade is essentially a barter, an exchange of surplus commodities. One country exports to another only because it has a surplus of some commodity which it can 
exchange for something of which the second country likewise has a surplus. The transaction is reciprocal in character and the goods exchanged must, in the long run, be equal in value. The exchange may, of course, be, and indeed usually is, indirect or "triangular." Any specific country may export to a second country from which it gets nothing in return, in order to use the credit thus established for the import of goods from a third country, but this does not destroy the reciprocal character of the transaction nor alter the fact that foreign trade is an exchange of commodities. The fundamental prerequisite to the exchange is the production by each of the exchanging countries of a surplus of something which the other peoples want: and the fundamental determining factor is to be found in an analysis of what these peoples want. Imports, in other words, psychologically come first. Export exists only for the purpose of paying for import.

The character of this demand for foreign goods depends on many things. A country producing chiefly foodstuffs must if it would progress economically usually import its manufactured goods: one which is pre-eminent as a manufacturer will usually be in need of foreign food supplies. Another which possesses abundant supplies of iron and facilities for manufacturing it, may find it profitable to purchase abroad its supplies of manufactured textiles.

Given a demand for foreign goods of any class, the determination as to where these shall be purchased, i. e., the origin of the imports, will likewise rest on many considerations, sometimes lying within the decision of the individual trader 
but probably more often settled for him by popular opinion: sometimes determined even by the foreign seller himself. If the goods demanded are bulk goods of uniform quality, or with differences in quality which it is difficult for the uninstructed public to understand, the individual trader may exercise a wide discretion. If the goods be highly specialized manufactures such as "fashion goods," i. e., goods which people learn to know by their size, shape, color, label, etc., the consumers' taste may be the sole determining factor. If the import be connected with some foreign investment of capital for the construction, say, of public works, the foreign lender may dictate in the matter. On the whole there seems to be a movement in international dealings toward an increasing number of transactions which approach the second class. This results from the spread of popular intelligence among the trading nations, a more widespread knowledge of the character of goods and their differences in quality: and it tends to reduce the position of the individual trader more and more to that of a mere agent giving expression to popular demand. Whether such a tendency can be proved to exist or not, it is certain that a very considerable proportion of the international trade dealings of to-day belong to the second class just mentioned. A consequence of this is that in regard to a very large number of the commodities that enter into international exchanges, mere price or cost is only one of many elements which determine the origin of imports. When the individual trader can himself determine where he is to purchase goods, there is a strong incentive for him to purchase in the cheap- 
est market. But when he is merely acting as an agent of popular demand many other less strictly economic factors may decide the point. What we may call sentimental considerations may turn the scale. Racial prejudice against a foreign country may prevent the growth of any large popular demand for its goods; while racial affiliations or political or intellectual rapprochements may create a popular leaning towards goods which may be actually inferior and dearer. The people may insist on having French or German or American goods, merely because the facilities of travel between their homes and one of these countries have produced a greater degree of familiarity with its products. Or the mere fact that people see the flag of a particular nation on its merchant vessels more frequently than that of another may produce a popular impression that it, as a great trader, must have the best goods for sale. It is in such ways that sentiment plays an important part in determining the direction of trade.

The factors determining the direction of trade, resting thus on the elements which make up popular demand for goods, are extremely complex. Prices, transportation charges, postal and telegraphic facilities for placing orders, time required for delivery, conditions of payment and credit, capital investments, racial and social conditions, facilities for personal intercourse through travel, mere habit, and many other things all play a part in determining whence imports are to come.

Much more simple, though still complex, is the question as to the route by which they come. Here the factors are 
almost wholly economic, though the elements which enter into the economic problem are many. The element of popular demand plays a much less important part here than in determining the origin of imports. It is generally a matter of complete indifference to a purchaser whether the goods he buys have reached him by this, that, or the other route: he is concerned merely in getting what he wants at a price which is satisfactory. There are, it is true, a few cases in which this is not altogether true, such as those which arise from the belief of purchasers that goods which travel over certain routes are improved or deteriorated as compared with similar goods coming through other channels. Such for example is the case of tea, which is still in many parts of the world believed to suffer in quality if carried by sea; or of lemons or whiskey, which are supposed to be improved by a sea voyage. Concerning the great mass of ordinary articles of commerce, however, such considerations play no part. The choice of route concerns either the selling merchant, if the price has been made on a c. i. f. basis, or the purchasing distributer, if the price is f. o. b.: and even with them the question is only of indirect importance. The choice of route touches them only through the medium of freight rates. They select the one which offers them the lowest freight-all elements of time, safety, reliability, etc., being considered.

The choice of route is, then, mainly an affair which concerns the transportation companies. Assuming that real competition exists between different companies, it will be their aim to offer to the shipper, transportation of his 
goods by the cheapest, quickest, safest means which will yield current rates of profit on the company's investments. Their choice of route will tend to settle upon that one which offers the greatest facilities in these respects.

The problem of the Panama Canal is thus really a twofold one. The origin of imports, the determination where they shall be purchased, depends upon one set of factors; the route by which they shall come depends upon quite a different set. The problem we are considering is primarily the former; we are only indirectly concerned with the latter. We are not considering the Panama Canal as a business enterprise; we are not directly concerned with determining whether as a business concern, it will "pay." Our object is to form some idea, if possible, how, if it is used, it will affect the trade of nations. The two questions are, of course, intimately connected with one another. If it is not used at all, it can produce no effect whatever; the extent to which it is used will be an important factor in determining what its results on the interchange of commodities will be. Still, it will conduce to clarity of thought in the matter, if it is remembered that the two problems are distinct from one another.

The origin of imports depends, as already stated, on such considerations as prices, freight rates, postal and telegraphic facilities for placing orders, time required for delivery, conditions of payment and credit, capital investments, racial and social conditions, sentiment, habit, facilities for personal intercourse through travel, etc. The only way the canal can effect changes in the determination of the origin 
of foreign purchases will be through alteration of some or all of these factors. Only in this indirect way are we concerned with the question of route at all. Our concern is an intimate one and yet, after all, it is an indirect one. If we are to form any estimate of the influence of the canal, we must first determine how it is likely to affect routes, and then ask how the changes in routes will react on the factors which determine the place of purchase of goods.

The question is thus one of extreme complexity. It bristles with most formidable difficulties. How will it be possible to analyze the intricate actions and reactions of so heterogeneous a series of factors? Serious differences of opinion exist among men of long experience as to the relative importance of these various factors. If it were possible to assign to each its due weight as a determinant of the direction of demand the whole affair would be far simpler. But who can say in any particular case, what the exact relative influence is of price and sentiment, of capital investments and habit, of easy communication and conditions of credit, in determining whether goods shall be purchased in this, that, or the other country? The most that could be hoped for is a very rough approximation. There is a way, however, out of some, at least, of these difficulties. It lies in adopting a method of investigation which in a certain sense eliminates the necessity of a relative evaluation of the separate factors by seeking to ascertain what the net results of the interaction of all the factors as a whole, is. The countries with which we are concerned have been trading with each other for a long time. All the factors 
which determine the origin of imports have been operating under the old conditions as to routes. If we can determine what the results of their operation in the past have been we may relieve ourselves of the necessity of placing an exact value on any one of them and be able merely to ask ourselves what changes will take place in them. If, for example, it can be shown that the operation of all these factors together under present and past conditions, is such as to cause an increasing demand for, say German goods in Peru-in other words, that the net effect of the interaction of all existing stimuli to German trade in Peru has been to increase Peruvian purchases in Germany; and if it can be shown that the opening of the canal will render one or more of these stimuli more active without decreasing the force of others, it will be safe to predict an increase in German exports to Peru when the new route is available. Only if some of the stimuli were affected positively and others negatively would it be necessary to place definite relative values on them. As between two competing countries, say the United Kingdom and the United States, if it could be shown that the demand for American goods has been on the increase in Japan, and that the opening of the canal would affect the stimuli to American trade without materially altering the forces which have promoted a demand for British goods, it would be reasonable to conclude that the new route would make for an expansion of the American market in Japan.

All difficulties will not, by any means, be removed. Not only in those cases in which the stimuli are altered, some 
of them positively and some negatively, but in those cases in which, as regards two countries, the stimuli which are altered positively are different in the two cases, will it still be necessary to form some judgment as to the relative efficiencies of these stimuli before any prediction can be made as to the results of the change. Nevertheless the fact that the method of investigation proposed offers any simplification of the problem, does give promise of enabling us to make some forecast as to the commercial effects of opening the canal.

It is proposed, therefore, in the following chapters, to examine the trade of the countries which are at all likely to be affected by the changes in trade routes, using the statistics of the past ten or fifteen years, with a view to determining first of all, what the trend of development has been; to plot the curves, so to speak, of growth or decline, and to learn as much as may be of the causes which have led to their assuming the particular forms which we shall find them to possess. Then, having determined the direction and character of the curves, the new factor, the canal, will be introduced, and attention will be centered on the question how this new factor, operating through the various stimuli to trade, may alter the direction or character of movement.

There is nothing novel in this method of investigation. It is one which is already familiar in many sciences, or at least something very similar to it appears in many scientific investigations. It is analogous, for example, to the method which would probably be used by astronomers in 
predicting changes in the orbits of the planets if a new world were suddenly to be introduced into the solar system. The application to a social problem like commerce is of course difficult in the extreme, but if its limitations are recognized, valuable results may nevertheless be attained. 


\section{CHAPTER II}

ROUTES

IT is evident from the analysis presented in the preceding chapter that whatever changes the opening of the Panama Canal will effect in the direction of international trade must be the result of alterations of trade routes. The changes in routes will be the medium through which the trade influence of the canal will be transmitted. Not every modification of routes will alter the geographical distribution of markets, but no alteration in the latter will take place without a change in the former. It becomes necessary, therefore, before taking up an examination of the markets to form some sort of opinion as to the manner and extent to which the opening of the canal will alter the highways of commerce.

The commerce with which we are concerned is that of the Pacific Ocean countries-Chile, Peru, Bolivia (so far as its trade finds an outlet via the Pacific), Ecuador; the Pacific Coasts of Colombia, Central America, Mexico, the United States, and Canada; Alaska; the Pacific Coast of Asiatic Russia; Japan, China, French Indo-China, Siam, the East Indies, New Guinea, Australia, New Zealand, and the Pacific Islands. The trade routes which can conceivably be affected by the opening of the canal are those which con- 
nect these countries with the nations of the Atlantic Ocean basin. The Panama canal route must compete with commercial highways already in existence; and in order to form any judgment as to what success it is likely to have in this competition it will first be necessary to get clearly in mind what these present highways are and the causes which have fixed them where they are. For this purpose, the report of the Isthmian Canal Commission on the shipping and trade of the Pacific Ocean as it existed in 1909-1o is of invaluable assistance. ${ }^{1}$ In the following pages this report has been very extensively drawn upon.

There are to-day three main lines of all-sea communication between the Atlantic and the Pacific regions; by way of the Suez Canal, the Cape of Good Hope, and Magellan Straits. All three of these are used by steamers. A fourth route is used by a decreasing number of sailing vessels, namely that via Cape Horn. The Suez Canal is not made use of by this latter class of vessels because of difficulties of approach and toll charges: nor is the Magellan route, because of dangers of navigation. Sailing vessels reach the Pacific either via Cape Horn or via the Cape of Good Hope.

By far the larger part of the commerce between the two oceans is carried over the all-sea routes, with the exception of the trade between the two coasts of the United States, between the two coasts of British North America, and between the United States and Mexico. Of the all-sea traffic, that of the Pacific Coasts of North and South America is carried on chiefly via the Straits of Magellan. The com-

1E. R. Johnson: Panama Canal Traffic and Tolls; Washington, 1912. 
merce with the eastern coasts of Asia goes mostly via Suez, while that of Australia, New Zealand, Southern Asia and the East Indies uses either the Suez Canal or the Cape of Good Hope route; large, fast steamers carrying passengers and mail ordinarily choosing Suez, while slow freighters prefer the Cape. Many of these freighters make the return voyage via Magellan. Such sailing vessels as are still operating in this trade of course use the Cape route. ${ }^{1}$

It is the general opinion of shipping men, so widely held that it may be accepted without question, that the sailing vessel is rapidly disappearing from international trade. Hence in any discussion of the influence of the Panama Canal on trade routes we may leave them out of consideration, and may simplify our problem by comparing only the three great all-sea routes actually used by steamers.

The factors which determine the choice of ocean routes include such heterogeneous items as distance, ocean currents and winds, weather conditions, dangers of navigation, distances between fuel stations, costs of fuel, wayfreight markets, passenger traffic, toll charges, etc. Any attempt to make a general statement in regard to the merits of a particular route, which shall include an estimate of all of these items, must result in confusion. If, however, we can select from among these numerous factors those which play the most important part we may perhaps get a rough, general guide which will help us in discovering what the

${ }^{1}$ These statements can, of course, be accepted as applying only to what may be called the normal movement of vessels. There are many individual exceptional cases especially those in which a vessel makes the outward voyage by one route and the return by another. 
probabilities of choice would be between two alternative routes. Now it so happens that among these ten or a dozen factors which influence the choice of routes three or four stand out pre-eminently. The first, and the one exercising the most profound influence is obviously distance. If it be assumed that the cost of operating the average freight steamer of 3,000 net registered tons and ten knots speed is $\$ 300$ a day, the saving of a few days' distance must be a much more important consideration, except under very exceptional circumstances, than many of the other items above mentioned. The truth of this statement is brought out if we compare the effects of increased distance with the results of certain other adverse conditions. Suppose, for example, that in order to save a day's distance by some newly opened route a steamer of the sort just mentioned should be obliged to encounter an adverse ocean current. A current of twenty-four knots a day for any considerable distance is an exception in the ocean. In order that the benefit of saving one day's sailing for a ten knot steamer should be counteracted by such a current, the conditions would have to be such that the steamer in choosing the new route must face the current for at least ten days. It is doubtful whether anywhere in the ocean on any possible trade route a current of this extent and average speed could be found. Most currents are far weaker and much more quickly traversed. The few currents that are faster owe their speed largely to the fact that they are much more limited in extent. They are consequently rather easily avoided by unimportant detours. It seems safe to say that 
only in an exceptional case would a steamer be likely to avoid a route which offered even one day's saving of distance, merely to escape an adverse current, or to take advantage of a favorable one.

The most important consideration to the shipowner, after saving of distance, is probably the saving of fuel costs. An ordinary ten knot freighter of the size mentioned burns something like thirty tons of coal per day. The average cost of coal in the chief coaling stations on the world's trade routes is about $\$ 4.70$ a ton. Of the $\$ 300$ average daily cost of operation of the average freight steamer, therefore, no less than $\$ \mathrm{I} 4 \mathrm{I}$, or 47 per cent. is the outlay for fuel. If saving of distance and costs of fuel were the only two considerations determining the choice of two alternative routes, it would, therefore, be an easy matter to reduce the problem to a mathematical statement. On a round trip voyage occupying say sixty days' sailing time each way a new route cutting down the distance by a single day's steaming each way would offer no saving of expense over the old route if the average cost of coal by it were enhanced by only ten cents a ton. On the other hand, a new route cutting down the sailing time of a sixty days' round trip by five days each way would offer a considerable saving even if the cost of coal by the shorter route were fifty cents a ton higher. On long ocean routes, such for instance as those leading to the Orient, the differences in average costs of coal by alternative routes probably do not exceed $\$ 1.20$ a ton. If this be taken as a fair average of extreme differences it is possible to estimate approximately 
the limits of influence of this factor in determining the choice of routes. On a one hundred and twenty day round trip a saving of a little over twelve days each way, by choice of a new route on which the fuel costs were $\$ 1.20$ per ton higher, would leave the costs of the voyage equal by either route. It would probably require a saving of thirteen days to turn the scale in favor of the shorter route. Similarly, other things being equal, a saving of seven days on a sixty day round trip, or of three and one-quarter days on a thirty day trip would be necessary in order to cause a preference for the new route.

Toll charges are likewise one of the large items of expense and their influence in determining choice of route may also be stated in fairly definite form. The estimated cost of operation of ordinary freight steamers stated above at about $\$ 300$ a day is based upon an average which has been calculated at approximately ten cents per day per net registered ton. ${ }^{1}$ The charge for tolls in both the Suez and Panama canals is also based on net tonnage, the rate being practically the same in each case-six francs, twenty-five centimes at Suez and $\$ 1.20$ at Panama-with some slight differences in the method of measuring net tonnage. Between these two routes, therefore, there may be said to be no choice in this respect. But when it comes to a decision whether a particular ship is to use either canal or some other alternative route, the question of preference, other things being equal, becomes one of simple arithmetic. The operating costs being ten cents per ton and the tolls $\$ 1.20$ per ton,

${ }^{1}$ Johnson: Panama Traffic and Tolls, pp. 176-9. 
any route which required more than twelve days longer than the canal route would be abandoned in favor of the canal. In other words, for the average freight steamer it would require a saving of time of at least twelve days, by the use of a canal route, to offset the deterrent effect of a toll of $\$ 1.20$ per net registered ton. It is necessary to emphasize the fact that this statement applies only to the ordinary freighting vessel of say ten knots speed. For faster vessels, such as are now ordinarily used for combined passenger and freight service the per diem costs per net ton are of course larger. For a twelve knot vessel of this class the costs are probably fifteen cents per ton per day: for a fifteen knot boat, they may run up to twenty cents. Obviously, the repelling effect of tolls becomes less for such vessels. For the twelve knot boat, an eight days' saving of time would offset the tolls: for a fifteen knot one, six days would be sufficient.

Much more difficult to reduce to a calculable basis is the effect of opportunities for picking up local freights and passengers. Rates of transportation of both freights and passengers vary greatly, as do also the profits on the business, especially between way ports. It would probably be impossible to form any useful opinion as to the relative value of this sort of business compared with through business, but it may not be impossible to find a basis of comparison in this respect of two competing routes. The amount of local freight and passenger business must bear some more or less definite relation to the number of way ports and the population and commercial activity of the 
countries in which these ports are situated. Of two alternative routes, that one which has the greatest number of stations, with the larger population, and the greatest general commercial activity, must offer the greatest opportunities for local business. So that while it may be impossible in advance to say whether the business of this kind picked up on any particular route will be sufficient to pay the cost of losing one or two or ten days' time in order to take that route rather than a shorter one, it may nevertheless be possible to arrive at some judgment, other things being approximately equal, as to whether one route would be preferable to another in this respect. For example, it may be impossible to say whether local traffic between San Francisco and Yokohoma would yield sufficient return to make it worth while for a vessel bound from Panama to Yokohama to call at San Francisco; yet it is practically certain that there is much greater likelihood of such a stop being profitable than a stop at Honolulu en route from Panama to Yokohama.

The other factors which enter into the determination of the choice of route by vessels are of very minor importance compared to those which have now been discussed. Insurance rates are not likely to be very different on the various alternative routes. The prevalence of storms, unless it be very marked in some particular locality, does not play a great part in altering the routes of steamships. It may cause them on a single voyage to alter their courses somewhat, causing some delay and thus lengthening that voyage, yet, on the whole, in the course of a year, the addi- 
tion to the expense account is obviously very slight. It would determine choice of route only if all other things were quite equal and competition were very close. The same may be said in regard to differences in port charges. At terminal points, charges would of course be identical by either of two alternative routes. Only at way ports at which a vessel might stop to discharge or receive passengers or cargo would differences between the two routes make themselves felt and then they would only form one of the elements in the expenses of way freight and passenger business. Only in those cases where this local business furnished a large part of the income of a shipping company would the question be likely to become one of much concern.

This brief analysis of the relative importance of the elements which go into the determination of choice of trade routes makes it obvious that the most potent factors in determining whether vessels engaged in any particular traffic will abandon the routes which they now use in favor of the Panama route will be the question of distance, the outlay for canal tolls, the cost of fuel supplies, and the possibility of getting way freights and passengers. In the main, the other factors, though operating, will be of much less moment. Only where the relative merits of the canal route and some other are closely balanced would these other factors need serious consideration.

These elements which may be regarded as the chief determinants of the choice of routes naturally fall into two classes; one relating to the operating expenses of the steamship company; the other to its income. On the one side 
must be placed the relative cost of operating a vessel over one route rather than another, including the general operating expenses, the amount of coal consumed, the cost of the coal, and the tolls payable, if any. On the other side of the account will be the income from freights, which will obviously depend upon the amount of cargo which can be carried per voyage, the rates which can be charged, and the number of voyages which can be made during a given period such as one year. To this must be added passenger and mail receipts, way freights, way passenger receipts, etc., for such vessels as carry mails and passengers or which do a way freight business. For many vessels, also, subsidy payments add a large item.

In spite of the elimination of minor items, these factors which remain are, therefore, sufficiently numerous and complex to leave the problem still a most confusing and difficult one. It will be desirable, if possible, to get still further simplification, and this we may do by confining our attention to one class of vessels only.

Speaking broadly, the international trade of the world is carried in two distinct sorts of vessels; liners plying on definite routes on a more or less fixed schedule with sailing dates announced often many months in advance; and tramps, sailing when, and to the port for which, they can get cargo. The liner, in general, is the vessel which, because of its fixed schedule and route, carries the bulk of the passenger traffic of the world and if it is of sufficient speed gets mail contracts and shipping subsidies where such exist. Sailing on definite schedule, whether it has a cargo 
or not, this sort of vessel is the one most likely to have space for and be most interested in seeking way freights. The tramp is far more likely to have full cargo from its port of clearance to its final destination.

It is well known that the bulk of the world's ocean freights are carried by this tramp class of vessel. Just how large the proportion is it is impossible to say with any degree of certainty, but it is probably well over one-half of the total, especially in regions like the Pacific Ocean basin the countries of which export chiefly bulky raw and semi-raw materials. Of the steamers entering and leaving San Francisco, for instance, in the year I9II, over two-thirds belonged to the tramp class and less than one-third to the liner class.

If, therefore, in examining the relative merits of two routes, we confine our attention to tramps, and assume that they sail with full through-cargoes, we shall get comparisons which will cover a considerable share of ocean commerce, and may get results which, although they may not be conclusive, will at least be suggestive. And we shall eliminate from our problem the confusing and intricate factors of mail, passenger, subsidy, and way-freight receipts, leaving only to be considered the expenses of operation and the annual freight receipts.

The average size vessel of this sort is about 3,000 net registered tons, the cargo carrying capacity, about 6,000 tons, speed about ten knots, and the coal consumption about thirty tons per day. ${ }^{1}$ The cost of such a vessel is somewhere in the neighborhood of $\$ 300,000$ and its owners 
aim to make an annual profit of about 25 per cent. on their investment. The general operating expenses; salaries and wages (both in land offices and aboard ship), provisions, maintenance and repairs, insurance, taxes, etc., have been put at an average of $\$ 160$ a day. The only other item of expense, that for fuel, varies with the price of coal at fuel stations. Such an average vessel is at sea under steam approximately two hundred and thirty days in a year and in port the remaining one hundred and thirty-five days. The operating costs while at sea may be taken, therefore, at $\$ 160$ per day for general expenses, plus the cost of thirty tons of coal per day at the prices ruling at the ports where the vessel took on fuel. The operating costs while in port will be merely the $\$ 160$ a day for general expenses.

Using these average figures as the basis for estimating costs via two competing routes it would seem that we might get results which although they would probably not be applicable to any particular vessel, would at least be comparable with one another and help us form some judgment as to the relative merits of the two routes.

This point can best be illustrated by giving a specific instance. A vessel going from Liverpool to Wellington may choose either the Suez or the Cape of Good Hope route. If it takes the former its expense account will be somewhat as follows:

For the round trip: 
108.2 days under steam @ \$160 a day for general expenses.....

Tolls @ 6 frcs. 25 cents. per net registered ton, $\$ 3,600$ each way. .

Coal: Liverpool-Gibraltar..........162 tons @ 25/3 ${ }^{1}$ \$1,023

Gibraltar-Port Said........240 " " $23 / 0 \quad$ I,380

P. Said-Colombo..........429 " " $25 / 6 \quad 2,734$

Colombo-King George Snd. ...423 “ " $26 / 0 \quad 2,749$

King George Snd-Melbourne ..20I “ “ $25 / 6$ I,28I

Melbourne-Sydney......... 72 " " $19 / 6 \quad 35 \mathrm{I}$

Sydney-Wellington \& ret......320" "

Sydney-King George Snd..... 273 " " $16 / 0 \quad 1,092$

King George Snd-Colombo....423 " " $25 / 6 \quad 2,696$

Colombo-P. Said..........429 " " $26 / 0 \quad 2,789$

P. Said-Gibraltar.........240" " $25 / 6 \quad 1,530$

Gibraltar-Liverpool..........162 " " $23 / 0$

Cost per round trip.............. \$44,349

${ }^{1}$ Contract prices, I9I2. See Johnson, pp. I57-I70.

If it chooses, instead, the Cape route, the costs will be:

III.2 days under steam $@ \$$ I60.

$\$ 17,792$

Coal: Liverpool-Durban...........759 tons @ 25/3 \$4,79r

Durban-Sydney...........83 " " $13 / 0$ "2,701

Sydney-Wellington \& ret.....320 " " I6/0 I,280

Sydney-Durban..........83I " " $16 / 0 \quad 3,324$

Durban-Liverpool..........759 " " ${ }_{3 / 3} / 0 \quad 2,467$

$\$ 14,563$

Cost per round trip.............\$32,355

The annual costs for two exactly similar vessels running, one via Suez, and one via the Cape would be:

Via Suez:-2.I2 round trips (230 days) @ \$44,349..... \$93,I33

General expenses in port ( $\mathrm{I} 35$ days @ $\$ 160) . . . \ldots \ldots \ldots .21,600$

Total annual expenses............. \$1 44,733

Via the Cape:-2.07 round trips @ $\$ 32,355 \ldots . \ldots \ldots \ldots . \$ 67,946$

General expenses in port................... $2 \mathrm{I}, 600$

Total annual expenses............. \$89,546 
This gives us a basis for a rough comparison of the annual expenses of the two vessels; but the annual income must also be considered. On the assumption that the vessels will carry full cargoes, each will take on every voyage all the freight it can put into the space not occupied by the necessary coal. The carrying capacity of each is assumed to be 6,000 tons. Each must surrender enough of this space for use as coal bunkers, to give it a sufficient supply of fuel to carry it over the longest distance between stations. On the Suez route the largest amount of space thus sacrificed will be four hundred and twenty-nine tons (coal from Port Said to Colombo): on the Cape route, eight hundred and thirty-one tons (Durban to Sydney). The former, therefore, on a round trip can carry II,I42 tons of freight, and in a year 23,398 tons; the latter, 10,338 tons on a round trip, and 21,710 per annum. Assuming, again, that each would aim at making an annual profit of 25 per cent., and that the capital investment is $\$ 300,000$ per vessel, the Suez vessel would find it necessary to get an

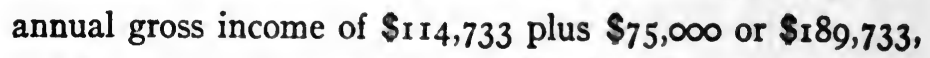
and in order to do so would be obliged to charge an average freight rate of $\$ 8.19$ per ton: the Cape vessel's annual gross income would have to be $\$ 89,546$ plus $\$ 75,000$ or $\$ 164,546$, and its freight rate $\$ 7.5^{8}$ per ton. Clearly, the Cape route would be given preference.

This method of comparison is, obviously, based on a series of rather violent assumptions; that the bulk of ocean freight is carried by tramps, that the average size of such vessels is 3,000 net tons and the carrying capacity 6,000 
tons; that the average speed is ten knots per hour and the coal consumption thirty tons per day; that the average investment is $\$ 300,000$ and the annual profit aimed at, 25 per cent.; that the average number of days at sea is two hundred and thirty per annum and in port one hundred and thirty-five; that the expenses other than for fuel average \$160 per day and that fuel prices are those of I9I2; that full cargoes will always be carried; and that, on the whole, there will be as many vessels moving in one direction as the other on any particular route. It would be absurd, therefore, to imagine that the figures arrived at have any value as absolute quantitative measurements. But, if exactly the same assumptions are made in every case, if the average figures used may be accepted as at least being somewhere near the truth, and if they include allowances for the chief factors which are likely to affect the choice of routes by the particular class of vessel considered, it may not be unreasonable to believe that the calculations furnish a fairly correct basis of comparison between such routes.

In the illustration given above concerning the routes from Liverpool to Wellington, the figures arrived at for freight rates between the two ports, of $\$ 8.19$ per ton via Suez and $\$ 7.58$ via the Cape have of course no validity in themselves, but as units upon which to base a comparative estimate of the relative merits of the two routes, they are at least significant. They focus within themselves, so to speak, the more important elements of the problem, time (distance), fuel costs, general operating expenses, toll charges, income, and normal profits. If we, therefore, 
make a comparison of the various all-sea routes from the Atlantic to the Pacific based upon figures reached by this method, we shall be likely to get results which will at least be suggestive.

The all-sea routes from the Atlantic to the Pacific, to-day, are, as has already been stated, three in number: via Suez, via the Cape of Good Hope, and via Magellan Straits. The new Panama route will enter into competition with all of these. In order to get a complete estimate of the facilities offered by the new canal it would be necessary to examine the costs and receipts on every specific route from every Atlantic port to every Pacific port between which trade is being or may be carried on. Obviously such an estimate would necessitate a large amount of labor and would be likely to result in confusion through the multiplicity of details. Again, a simplification by elimination has been attempted. The bulk of the trade from the Atlantic to the Pacific originates in the Atlantic States of the United States or in Northwestern Europe. New York handles most of the American trade and half a dozen ports like Liverpool, Southampton, London, Havre, Rotterdam, and Hamburg, handle the European. If we analyze conditions for New York we shall get a fair idea of the relation of the canal to routes from America. Similarly, if we analyze conditions for any one of the European ports just mentioned we shall get a fair idea of its relations to Europe; for the effects of the canal on the routes from these various European ports will not greatly differ. They are so situated that distances, costs, etc., from any one of them will be about the same 
as from any other. We shall not go far wrong, then, if we choose Liverpool as the typical European port, and make our comparisons for New York on one side of the Atlantic and Liverpool on the other.

On the Pacific end of the routes such a complete simplification is impossible. The best we can do is to select from the hundreds of ports a few which may be regarded as representing the more important regions. The following may be regarded as the typical Pacific Ocean ports:-for Southern Chile, Coronel; Central Chile, Valparaiso; Northern Chile, Iquique; Peru, Callao; Ecuador, Guayaquil; Central America, San Josê de Guatemala; Western Mexico, Acapulco; Pacific Coast of the United States and British Columbia, San Diego, San Francisco, and Seattle; Japan, Yokohama; Northern China, Shanghai; Southern China, Hongkong; Philippine Islands, Manila; Straits Settlements, Singapore; East Indies, Batavia; Southern Australia, Melbourne; Eastern Australia, Sydney; and New Zealand, Wellington.

Calculations, made as already indicated, for the various routes from New York and Liverpool to these nineteen Pacific ports give the results shown in Tables I, II, III and IV in the Appendix.

If we assume that in general (for vessels of the type we have been considering) that route will be chosen which gives the lowest rate per ton, calculated in the manner indicated, then the Panama route will be used (if toll rates remain as at present fixed, at $\$$ I.20 per net registered ton) as follows: 
From Liverpool

To

Coronel

Valparaiso

Iquique

Callao

Guayaquil

San José de Guatemala

Acapulco

San Francisco

Seattle

Wellington

The Suez route will be used

From Liverpool

To

Yokohama

Shanghai

Hongkong

Manila

Singapore

Batavia
From New York

To

Coronel

Valparaiso

Iquique

Callao

Guayaquil

San José de Guatemala

Acapulco

San Francisco

Seattle

Yokohama

Shanghai

Melbourne

Sydney

Wellington

1 Manila

${ }^{1}$ No difference between the Suez and Panams routes.

The Cape route will continue to be used from Liverpool to Melbourne and Sydney.

For vessels of a larger, faster type, the passenger and mail steamers of to-day, a different set of calculations is required. Such vessels in use on routes to the Pacific Ocean basin average approximately 5,000 net registered tons in size, have a speed of about fifteen knots, and burn about seventy tons of coal a day. The average running expenses 
reach about $\$ 700$ a day exclusive of fuel. The average capital cost of such vessels is taken at $\$ 800,000$.

Calculations, exactly similar to those above, for vessels of this class give the results shown in Tables V, VI, VII and and VIII in the Appendix.

These tables show that if no other elements than those included in the calculations entered into the problem, we might be justified in concluding that the Panama Canal would be chosen by vessels of the fifteen knot class on practically the same routes as those preferred by the ten knot vessels. But the receipts from passenger traffic, mail contracts, way freights, and subsidies will here play an important part and will in many cases be a determining factor. For example, according to our calculations for a fifteen knot vessel, the Cape of Good Hope route is ninetyfour cents a ton or Io per cent. cheaper than the Suez route on the voyage from Liverpool to Melbourne, and twenty-four cents, or 3 per cent. cheaper, from Liverpool to Sydney; yet it is a well-known fact that such vessels prefer the Suez route. In other words, the Suez route to-day offers inducements of a sort not included in our calculations sufficient to counterbalance a io per cent. advantage in the Cape route. On the only routes from Liverpool in which the Panama Canal may compete with Suez (to Wellington), the advantage of Panama is only sixty cents a ton or less than 7 per cent. and it is probable, therefore, that the Suez route will continue to be used.

For fifteen knot vessels from New York, the advantages of the Panama route, where any advantage exists, are in 
every case well over ro per cent.; to Shanghai, 2 per cent.; to Yokohama, 25 per cent.; to Melbourne, 21 per cent.; to Sydney, 27 per cent.; and to Wellington, 36 per cent. It is not unlikely, therefore, that the Panama route will be chosen by vessels bound for these ports in spite of mail, passenger, and way-freight attractions of the Suez route. To Hongkong, on the other hand, the calculations putting the two routes on an exact equality, it is probable that the Suez route will be chosen in many cases at least.

On the American shores of the Pacific, the advantages of the Panama over the Magellan route are, on the whole, too great to be overcome by other considerations. From New York, even to the southernmost port on the list, Coronel, the Panama route shows a rate of 39 per cent. cheaper than the Magellan: to Guayaquil, the advantage of the Panama route becomes 70 per cent. Only in regard to vessels from Liverpool to the southern South American ports would there seem to be any doubt. The advantage of the Panama over the Magellan route to Coronel is only II per cent. and to Valparaiso, 16 per cent. It may well be that the way-freight and passenger business on the east coast of South America, at Buenos Aires, Montevideo, Rio de Janeiro, etc., will furnish sufficient attractions to keep these vessels in their present channels.

On the whole, then, it may not be far from the truth to conclude that for vessels of the fifteen knot class the situation after the competition of the Panama Canal shall have made itself felt will be about as follows: 
The Panama route will be used

From Liverpool

To

Iquique

Callao

Guayaquil

San José

Acapulco

San Diego

San Francisco

Seattle
From New York

To

Coronel

Valparaiso

Iquique

Callao

Guayaquil

San José

Acapulco

San Diego

San Francisco

Seattle

Yokohama

Shanghai

Melbourne

Sydney

Wellington

The Suez route will be used

From Liverpool

To

Yokohama

Shanghai

Hongkong

Manila

Singapore

Batavia

Melbourne

Sydney

Wellington
From New York

To

Singapore

Batavia

Doubtful will be: the routes from Liverpool to Coronel and Valparaiso, and from New York to Hongkong and Manila.

From the facts thus brought out concerning the probable routes of the two classes of vessels, if it be assumed that they are even approximately correct, several important conclusions may be drawn. They may most clearly be indicated by reference to the following table. 


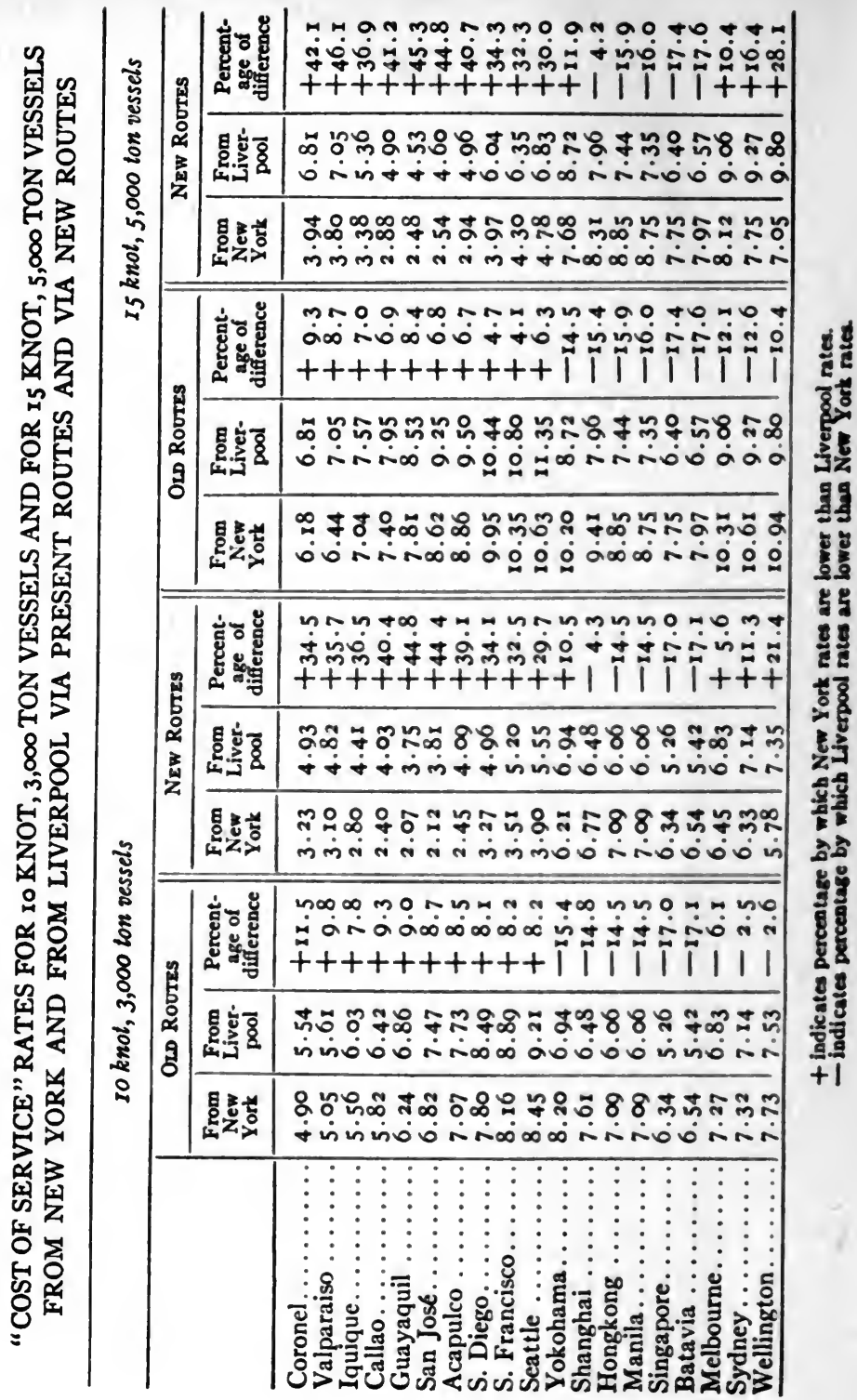


It will be seen at once that the development of the new routes makes a great difference in the relative positions of New York and Liverpool in relation to many of the Pacific markets. The rates which have been obtained by the calculations presented represent comparative costs of service. By the old routes, for both classes of vessels New York has a slight advantage over Liverpool to ports on the west coast of North and South America, ranging from 7.8 per cent. in the case of Iquique to II.5 per cent. in the case of Coronel, for vessels of the ten knot class; and from 4.I per cent. to San Francisco to 9.3 per cent. to Coronel, for fifteen knot vessels. The use of the Panama Canal will increase New York's advantage from five to tenfold, the cost of service becoming from 30 to 46 per cent. cheaper from New York than from Liverpool.

For the Australasian ports New York now stands at a disadvantage compared with Liverpool, ranging from $21 / 2$ to 6 per cent. for ten knot vessels and from $101 / 2$ to I $21 / 2$ per cent. for fifteen knot vessels. The Panama Canal will convert this handicap into an advantage of from $51 / 2$ to $2 \mathrm{I} / 2$ per cent. for the slower, and from $10 \mathrm{r} / 2$ to $28 \mathrm{per}$ cent. for the faster vessels.

For ports in the Orient and the East Indies there will be far less change. For Hongkong, Manila, Singapore, and Batavia, there will be no alteration. For Shanghai, New York will still remain at a disadvantage, but it will be reduced from about I 5 per cent. to a little over 4 per cent. Only in the case of Japan (Yokohama) will the present disadvantage be converted into a distinct advantage. At 
present the costs of service from Liverpool are 15.4 per cent. cheaper than from New York for ten knot, and 14.5 per cent. cheaper for fifteen knot vessels. The new route will make the costs from New York 10 $1 / 2$ per cent. cheaper from New York than from Liverpool for the slower, and 12 per cent. cheaper for the faster ships.

It must again be emphasized here that the figures given have no significance as absolute measurements of the freight rates that are likely to be put in force. Their value is relative merely. It would be absurd, for instance, to imagine, on the basis of the calculations presented, that the freight rate to Wellington on a ten knot vessel will be just the $\$ 5.78$ per ton from New York given in the table, or the $\$ 7.35$ per ton from Liverpool. Actual freight rates depend upon a vast complexity of factors many of which have not been, and could not be included in any calculations such as those that have been presented. For line vessels, in general, it is a well-known fact that cost of service does not determine rates. The numerous shipping "conferences" to which the owners of such vessels are parties, in large measure eliminate competition and the rates are fixed on the monopolistic principle of "what the traffic will bear." Costs of service which are represented roughly by the figures given in the tables, in such cases give only a lower limit beyond which the rates cannot permanently sink: the actual rates may be far higher. It may nevertheless not be unreasonable to expect that whatever rates are actually made by vessels of this class, the cost of service from New York being higher or lower than from Liverpool, there will 
be a tendency at least for these actual rates also to be higher or lower and in somewhat the same proportions as the costs of service.

For tramp vessels, the ten knot class of the tables, the connection between cost of service and actual rates is far closer. The rates here are in most cases highly competitive and therefore tend to sink to the level of cost of service, and the probability becomes far stronger that the actual rates charged will bear a relation to one another fairly close to the ratios arrived at by our calculations.

On the whole, then, it seems justifiable to conclude from the tables given that New York as a result of the opening of the new canal will be likely to get, in the long run, lower freight rates than Liverpool, to the entire west coast of North and South America, to Japan and northern China, and to Australasia.

Another element of possibly even greater importance to the trade is the frequency and rapidity of service in the transmission of goods. The higher and more costly the class of goods the more important, of course, does this factor become.

By present all-sea routes New York is, in general, at a disadvantage compared with Liverpool. A reference to the tables presented in the Appendix shows that the time of delivery from New York to points on the west coast of North and South America is only a day and a half less than from Liverpool for ten knot vessels and one day for fifteen knot vessels. With the new route open goods from New York can be delivered by the slower vessels in about eleven 
days' less time than from Liverpool, and by the faster, in seven days' less time.

In Australasia, New York now labors under a disadvantage compared with Liverpool of something over three days' time for ten knot vessels, and about five and onehalf days' time for fifteen knot vessels (via Suez). The new route will put New York from nine to twelve days nearer to Australia and New Zealand than Liverpool, for the slower class of ships, and from four and one-half to seven days nearer for the faster.

For Batavia, Singapore, Manila, and Hongkong there will be no essential change in this respect, but for northern China and Japan New York's position will be greatly strengthened. Ten knot vessels now require eight days' more time, and fifteen knot vessels, five and one-half days' more time to go from New York than from Liverpool to Shanghai. With the canal open the difference against New York will become less than one day.

By present routes, ten knot ships from New York to Yokohama require about eight days longer than from Liverpool: via the new route New York will be eight days nearer than Liverpool. For the faster vessels New York's present disadvantage of five days will be converted into an advantage of five days.

The analysis of the all-sea routes between the Atlantic and the Pacific Ocean basins presented in the preceding pages makes it evident that so far as the traffic is waterborne, the new canal will offer certain very definite advantages to the shippers of the Atlantic and Gulf coasts of the 
United States that do not now exist. Their position as competitors with Europe for the trade of the west coast of North and South America, of Australasia, of Japan, and of northern China will be materially strengthened. Our examination thus far has, however, been confined merely to the all-sea routes, and will be incomplete unless the relation of the canal to existing land-and-sea routes is also analyzed. Many classes of goods get from the Atlantic States of the United States or from Europe to the Pacific countries either wholly overland or by a combination of overland and sea routes. Many of these commodities, especially those of high value relatively to bulk or weight, will continue to use the channels already established and the effect of the opening of the canal on trade in such commodities will be comparatively slight.

The present land-and-sea or wholly overland routes are those via the Trans-Andine Railway from Buenos Aires to Valparaiso, the Panama Railroad, the Tehuantepec Railway, and the various American and Canadian transcontinental railroads. Of the first three of these little need be said. The Trans-Andine Railway is too far removed from the main channels of Atlantic-Pacific trade, and its cost of operation over the high Andean passes is so great, that it is not likely ever to play an important rôle in the trade under consideration. The Panama Railroad will obviously cease to be a factor as soon as the canal is in full operation and hence need not be considered, and almost the same may be said of the Tehuantepec Railway. The costs of two transshipments on this latter route (from ship to railway at one 
end and from railway to ship at the other) plus the railway freight between Salina Cruz and Puerto Mexico is so great -over $\$ 2.50$ per ton-that in spite of the rather longer distance via Panama to certain Pacific ports and the toll at Panama (about sixty cents per cargo ton) there is little likelihood that it will continue to be used extensively except for local traffic.

The only really important overland competitors of the Panama route will be the great trans-continental railways farther north. The bulk of the traffic between the eastern and western sections of the United States and Canada, a large amount of the trade between Europe and western North America, and a considerable share of the commodity and passenger movement between both Europe and eastern North America and the Orient is carried on these railways. These railways will continue to hold a certain portion of this business and in regard to such traffic as does thus continue to use the old routes, the opening of the canal will, of course, have no effect on the positions of the various competitors for the markets, except so far as it may necessitate a lowering of railway freights. And even if the competition of the canal should force the railroads to lower their rates the effects on the relative positions of the competitors would be unimportant, for so long as rates were uniformly applicable to both domestic and foreign goods, whatever advantages American shippers might get from a reduction their European competitors would also get. In attempting, therefore, to form an opinion as to the influence of the Panama route it will be necessary to arrive at some judg- 
ment as to the extent and character of this traffic on which the canal will have no effect because its routes will not be changed from their present channels.

On this point there is a wide divergence of opinion, and indeed the problem is so intricate that any conclusion that may be arrived at can be accepted only with many reservations. ${ }^{1}$ Such high-priced goods as the tea and silk of China and Japan may continue to be carried as at present, across the Pacific to San Francisco or Vancouver and thence by special freight train to their eastern destination on this continent, or by further transshipment across the Atlantic to European ports. Yet even in regard to these there may be serious doubt. Silk, for example, now reaches New York from Yokohama by the San Francisco route in about twenty-one days, paying a through freight of \$120 per ton of 2,000 pounds. If, on the completion of the new canal, this commodity were to be carried direct from Yokohama to New York in the fastest steamers now plying between Yokohama and San Francisco (about fifteen knots), the delivery time would be extended to 27.2 days. The share of this through rate of $\$ 120$ a ton which goes to the ocean carrier is $\$ 40$ a ton. If the rate from San Francisco to New York via Panama were to be made proportional to this, the through all-sea rate from Yokohama to New York would be in the neighborhood of $\$ 80$ a ton and the shipper would therefore save as an offset to a loss of about six days' time, a sum of $\$ 40$ a ton. This saving would far more than cover the loss of interest for six days on the value of a ton 
of silk which is about $\$ 5,00$. It may well be, therefore, that even so costly an article as silk will seek the new route, and if this be so then there is a strong likelihood that most commodities will do the same except small packages of high value, in the shipment of which haste is the prime consideration.

Similar analysis leads to the conclusion that the bulk of the traffic between the two seaboards of the United States and Canada will also seek the canal route. The through rail rate to-day from New York or Pittsburg to San Francisco on harvesters, reapers, etc., is $\$ 25$ a ton of 2,000 pounds. The cost of service rate for steamers, calculated as in the tables already presented (assuming that toll will be charged at Panama) is $\$ 3.5 \mathrm{I}$ a ton on ten knot vessels and $\$ 4.30$ on fifteen knot vessels. The time of delivery by fast freight is about twenty-one days: by ten knot steamers the sailing time would be twenty-two days, and by fifteen knot vessels, fourteen and one-half days. Even making enormous allowances, therefore, for possible errors in the calculations presented, it would appear quite certain that the Panama route would be given preference. Even on goods of the lowest rate class, such for instance, as nails, spikes, etc., it would seem equally certain that Panama would get most of the traffic, the rail rate from New York to San Francisco being $\$ 14.00$ a ton or several times as high as the cost of service rate of the tables.

Concerning routes from interior points in the eastern and central states to interior points in the Pacific States there is much more uncertainty, for to the all-sea rate from 
the Atlantic to the Pacific port must be added the local freights at either end from the interior point to the seaboard. The general conclusion of the Isthmian Canal Commission's report already referred to ${ }^{1}$ is that freights originating within a few hundred miles of the Atlantic and Gulf coasts and destined for points within a similar distance of Pacific coast ports will in all probability choose the canal route, and vice versa. We shall see, in a later chapter, that the chief demand on the Pacific slope of the United States and Canada is for highly manufactured commodities and that their principal export goods are such as seek a market in densely populated manufacturing regions. Since, therefore, the chief manufacturing sections of the United States are relatively near the Atlantic seaboard and the chief producing regions of the Pacific shore, near the Pacific, it seems probable that the bulk of the interchange between the two sections will take place via the Panama Canal.

In short, therefore, it seems highly probable that so far as the great trade movement from coast to coast of the United States and Canada, or from the Eastern United States to the Orient is concerned, the present all-rail or sea-and-rail routes are likely to be abandoned in favor of the canal route. If this be true, then the conclusions already reached in regard to the all-sea traffic hold good for this traffic as well, and the opening of the canal will tend to strengthen the position of our eastern manufacturing centers as competitors with Europe.

${ }^{1}$ Johnson. 


\section{CHAPTER III}

\section{THE PACIFIC COUNTRIES}

The Panama Canal will open a channel between two great commercial basins. Whatever influence it may have in promoting or stimulating commercial intercourse must be exerted through the alteration of trade routes. The probable changes in routes we have now examined in detail and have arrived at certain conclusions. Our next task must be to try to form some opinion as to the nature and volume of goods which will be carried by the new route. The countries of the Atlantic Ocean basin are sending a stream of goods into the Pacific for distribution to the peoples who live on its borders. The canal will so change routes as to alter the relative advantages and disadvantages of the various competing purchasers and sellers. Whether these alterations will produce changes in the markets for particular classes of goods will depend upon the ability of the purchaser or seller or both to respond to the new opportunities. For example, it has been seen that the canal will give a shipper from New York to Callao certain advantages in competition with an European shipper which he does not now possess. This points to an increased trade between New York and Callao. If, however, the character of goods which the merchants of Callao are demanding are of a sort 
which the merchants of New York cannot supply, or the products of Peru are not in demand in the United States, the opportunity offered by the opening of the canal may remain unutilized. In order to estimate the influence of the canal we must know something of the character of the markets at both ends of the routes which it will serve. This involves a study of the economic and commercial conditions in the countries which the canal will connect.

The countries of the Pacific which may be affected by the opening of the canal include practically all the lands which are touched by Pacific waters except southeastern Asia and the East Indies. Specifically the countries are: Chile, Bolivia, Peru, Ecuador, Colombia, Panama, Costa Rica, Nicaragua, Salvador, Guatemala, Mexico, the Pacific Coast of the United States and Canada, Alaska, Asiatic Russia, Japan, China, the Philippine Islands, Australia, New Zealand, and the Pacific Islands generally. Strictly speaking, several of these countries touch both the Atlantic and the Pacific Ocean basins. Colombia, the Central American States, Mexico, the United States and Canada all touch both oceans, and Bolivia's approaches are also both from the east (through Argentina) and the west (through Chile and Peru), yet they all, or certain parts of them must be regarded as belonging commercially to the Pacific rather than to the Atlantic. Bolivia is approached more easily from Antofagasta or Mollendo than from Argentina and most of her foreign trade already passes through these ports; the Central American States are approachable from both sides, but their Pacific ports will be within much 
easier reach of the great currents of trade than the Atlantic when the new routes through the canal to the west coast of the United States and Canada and to the Orient shall have been established, and the same may be said of Mexico so far as her foreign commerce is sea borne; and the Pacific slope of the United States and Canada within four or five hundred miles of the coast will be more accessible from the Pacific than overland by rail. Colombia, at present, belongs more definitely to the Atlantic basin, most of her foreign trade passing through Caribbean ports, yet there are possibilities of development at Buenaventura and Temuco on the Pacific which may in time alter that condition.

These two score or more of countries of the Pacific Basin offer striking contrasts in economic development. Not only do they differ fundamentally from the great commercial countries of the Atlantic Basin but the contrasts among themselves are enormous. A comparison of their areas, population, foreign commerce, etc., will emphasize this point.

The total area of these Pacific Basin countries, including the five South American countries named, the Central American States, the Pacific States only of Mexico and the United States, British Columbia, Alaska, Japan (and Korea), all of China except Tibet and Chinese Turkestan, the Philippine Islands, New Zealand, and the Australian States of Queensland, New South Wales, Victoria, and South Australia, reaches the enormous total of $9,539,000$ square miles or about one-fifth of the land surface of the earth. 
The aggregate population is $536,000,000$ or one-third of the world's total. The average density of population (56) is therefore greater than the rest of the world as a whole, though it is much less than in the great commercial nations of Europe. Their aggregate foreign trade, however, is relatively insignificant: the grand total of exports and imports $(\$ 2,658,000,000)$ is, for example, only about 40 per cent. of that of the United Kingdom alone. Their per capita trade $(\$ 5)$ is only one twenty-seventh that of the United Kingdom, and only about one-eighth that of the United States. The Pacific Basin therefore as a whole may be regarded as an unexploited area in the matter of international trade dealings.

There are, however, great contrasts among the Pacific countries themselves. The entire Pacific Coast of North and South America is a region of sparse population. The total area of the western countries of South America, Central America, the Pacific States of Mexico and the United States, British Columbia, and Alaska, 4,359,000 square miles, is greater than that of Europe, but the population, 3I,600,000, is less than that of Italy which is just the size of the single state of Nevada. The average density of population is only seven to the square mile. Only one country in the list, little Salvador, reaches what may be considered a dense population, one hundred and forty-eight to the square mile. No other Pacific American country reaches even twenty to the square mile though the State of Washington has seventeen and California fifteen.

As regards density of population Australia and New 
Zealand belong in the same class as these Pacific American countries just mentioned. The Australian Commonwealth as a whole with its $2,975,000$ square miles (equal in size to the United States exclusive of Alaska) has but 4,600,000 inhabitants, or only one and one-half to the square mile. Even its most densely populated states, those on the eastern and southeastern coasts, might almost be classed as uninhabited, with the single exception of the small State of Victoria, and even it has only fifteen persons to the square mile. New South Wales supports a population of only 5.2; South Australia, only I.I; and Queensland, only 0.9, per square mile. Tasmania, the smallest of the states, supports about seven to the square mile. A peculiar feature of the distribution of population is the high percentage of urban population. The Commonwealth may almost be said to be a country of cities. Six capitals, Melbourne, Sydney, Brisbane, Adelaide, Perth, and Hobart, contain over 35 per cent. of the total number of inhabitants of the entire country. The other sixteen towns of over 10,000 each, raise the urban population to about 45 per cent. of the total. The single city of Sydney contains 38 per cent. of the entire population of New South Wales; Melbourne, 45 per cent. of that of Victoria; and Adelaide, 47 per cent. of that of South Australia. Probably no other important country in the world presents such a concentration of population. New Zealand is somewhat more densely peopled but even here the country is relatively uninhabited, 10.5 to the square mile. The concentration is not quite so great as in Australia, the nine cities and 
towns of over 10,000 population aggregating only 38 per cent. of the total.

The contrast between these Australian countries and the Pacific American countries above mentioned, on the one hand, and the Oriental Pacific countries, on the other, is profound. The Chinese Empire, as a whole, supports ror people to the square mile; the Empire, exclusive of those parts which cannot be said to belong to the Pacific Basin (Tibet and Chinese Turkestan), I30 to the square mile; China Proper (the eighteen provinces), 266; Korea, I52; and Japan, the enormous number of 349. Even Manchuria has 44 persons on every square mile. In no other part of the globe of any considerable area (with the possible exception of India) is so dense a population supported chiefly on the products of its own soil. Several countries have a higher density, England for instance (669); the whole United Kingdom (375); Germany (310); Belgium (659); Holland (472), etc.; but these populations depend upon outside peoples for a large part of their supplies. The import trade of the United Kingdom reaches $\$ 73$ per capita per annum; of Germany, $\$ 36$; of Belgium, $\$ \mathrm{Ir}_{4}$; of Holland, $\$ 223$. The imports of Japan, on the other hand, are only $\$ 4.70$ per capita; of China, 70 cents.

The Oriental countries must, therefore, be regarded as inactive in international trade. A comparison, in this respect, with other Pacific countries, is instructive and interesting. The total foreign trade of China (imports and exports together) amounts to $\$ 1.27$ per capita; of Japan, to $\$ 8.95$. None of the Pacific countries on the American 
coast falls as low as this with the single exception of Colombia. Central America, as a whole, and Peru, average \$1 2 per capita; Mexico, \$16; Ecuador, \$17; Bolivia, \$21. Chile reaches a rather higher total of $\$ 76$ on account, largely, of the great value of her nitrate export. These figures seem large in comparison with those of the Oriental countries, but they are far surpassed in the case of Australia whose foreign trade reaches a surprising total of $\$ 142$ per capita, and of New Zealand, with a trade of \$174. The external trade of the Pacific States of the United States and of British Columbia can only be estimated, as so much of it uses land routes, but it probably ranges from $\$ 50$ to $\$$ roo per capita.

These contrasts it is important to bear in mind in attempting to form any judgment as to the commercial possibilities of the Pacific Ocean countries, for they unquestionably rest on causes which go to the very roots of trading activity and it is only through a modification of these fundamental forces that great changes of condition can come. Exactly what these fundamental causes are it is extremely difficult completely to analyze; yet some of them at least seem to be demonstrable. Density of population obviously has no very direct connection with commercial activity for there are as many instances of low density with high activity as there are with high density and high activity. Climatic conditions do seem, however, to be a potent factor. Only one of the tropical American countries which we have been considering has a per capita trade as large as $\$ 17$; and even this figure which belongs to 
Ecuador is due to the fact that the country has a semimonopoly of one important commodity, cacao. Even Mexico, which is partly without the tropics, and Bolivia, which while within the mathematical tropics, is, on account of its altitude, partly temperate, hardly pass this figure, having per capita trade of $\$ 16$ and $\$ 2$ I respectively. Temperate South America (Chile) and temperate North America (Pacific Coast States of the United States) show a much higher activity. Chile's trade reaches $\$ 76$ per capita and the North American countries at least as much and probably more. On the western shores of the Pacific a similar tendency is noticeable. Tropical Australia (Queensland for instance) has a trade of \$rog per capita; the temperate regions much more. New South Wales' figure goes to $\$ 175$, and Victoria's, to \$14I. New Zealand, wholly temperate, has a trade of \$174 per capita. The same condition seems to exist in China. Reliable figures of per capita trade of the various regions are not obtainable, but the total trade of North China (from Shanghai northwards) is more than double that of South China. Japan, wholly temperate except Formosa, is, as we have seen, much more active commercially than any part of China.

Another factor which unquestionably plays a part in stimulating commercial activity is the presence of European populations, especially those belonging to the north European or Teutonic races. The countries with low per capita trade as a rule have a low percentage of such population. None of the tropical countries of the Pacific Coast of North America has a European population of over 20 per cent. of 
the total and many of them have much less. Mexico has I9 per cent. In Chile the percentage goes much higher. In temperate North America as well as in Australia and New Zealand, the people are almost wholly European, while in China and Japan the percentage falls practically to zero. In a very roughly approximate way these differences, it will be observed, correspond with the difference in per capita trading activity.

This European population or population of European origin apparently makes itself felt in the foreign trade of the countries in two or three ways. Native-born Europeans, descendants of early immigrants or colonists, naturally retain something of their taste for European goods and devote their energies to the production of commodities with which they are able to continue their purchases of such goods. With European-born recent immigrants the connection is of the same sort but more direct. They are apt to demand not merely the goods which their European standards of living require, but also the goods of the specific country from which they came. The descendant of the colonists demands European goods; the German or Italian immigrant himself demands German, or Italian goods. Thus the German "colonists" of southern Chile swell the import trade from Germany and the English settler in the Australian bush looks to the United Kingdom for many of his supplies.

Another class, also, of European residents in these foreign countries and colonies exerts a direct influence on trade movements. They are the corporation officials, managers 
of enterprises, agents for this, that or the other activity financed from home. All such enterprises tend to swell the imports from the investing country during the period in which the investment is being made. When German capital, for example, gets a concession for a railway in China, the materials for the building are apt to come in larger measure from Germany than from other countries. After the investment is complete and the enterprise is a "going" concern, the dividends to the investors tend to swell the exports to Europe. The high per capita trade of Australia, New Zealand, Chile, British Columbia, and the Pacific States of America with regions outside their own borders is unquestionably due in part to these investments of the capital which has come to them from the outside.

Yet another factor may be regarded as of undoubted importance. The younger, more sparsely populated countries have a more important trade than the older, more densely populated ones. It seems to be a general law of economic development in the centuries since the middle ages, that new countries, if they have natural resources and an energetic population, rapidly develop a high degree of per capita trading activity. This unquestionably comes about through the fact that, with oversea transportation facilities, such countries at once find it profitable to devote their energy to the production of a surplus of raw materials rather than of the numerous other commodities of which they are in need, and to export the former in exchange for the latter. As, however, population increases, industries requiring a larger employment of labor become profitable 
compared with the extractive industries. A smaller relative production of raw materials follows and a larger relative production of the things which the people had been purchasing abroad; with the result that the per capita interchange of goods with foreign countries declines. Later still a further stage of growth is reached in which with increasing density of population a country is no longer able to supply itself with the needed foodstuffs and raw materials and in procuring these things for itself is forced to purchase them by expanding its foreign markets for manufactured articles, thus again tending to increase its per capita dealings with other nations. The great trading nations of Europe seem to have reached this stage. Their exports are, in the main, manufactured articles, while their imports are predominantly foodstuffs and raw materials. Such countries as Australia, New Zealand, Chile, and the Pacific Coasts of temperate North America are still in the earlier stage where trade is active because their sparse populations are able to produce a large surplus of the raw materials and foodstuffs which their territories supply and to sell them elsewhere in exchange for the finished products which their people demand. The Eastern United States is passing rapidly through a transition from the former to the latter stage.

China and Japan present an interesting exception to this general rule. With them the natural course of development was arrested by the adoption, partly at least through fear of political domination by foreigners, of a policy of isolation. Their abundant natural resources, sufficient for the needs of their earlier more sparse populations, and the exemplary 
industry of their peoples, enabled them for a long period to dispense with the necessity of commercial dealings with outsiders. The growth of population, however, began in time to press upon resources and as the fixed policy and the established habits of the people prevented their meeting their requirements by purchases abroad, physical need forced them into closer attention to procuring at home the necessaries of life-the things with which to feed and clothe their bodies. The result was stagnation. A people who are engaged in a life and death struggle to wring from their soil enough food to keep them from starvation, ceases to be able to produce much to exchange with foreigners, and the consequence is seen in China's foreign trade to-day of \$I.27 per capita, and Japan's of twenty years ago, of \$1.70 per capita. Japan is now, however, struggling out of that condition. Labor, before applied to the struggle to get enough food from the soil to feed the people, is being applied increasingly to the task of producing things which can be exchanged abroad for food. Net per capita imports of food which in 1890 were less than seven cents have risen now to fifty-seven cents, an increase of eightfold, and Japan's total foreign trade has grown from $\$$ r.70 per capita, to $\$ 8.95$. China is in the position which Japan occupied before the recent industrial revolution in the latter country began. The long isolation has resulted in so dire a struggle for existence that no great development can be expected until means are provided whereby the vacuum created by the transfer of labor from the production of food to the production of things which foreign nations require, has been 
filled by providing other sources of foodstuffs, either in foreign countries such as Siberia or in the less populated regions of China itself such as parts of Mongolia, or in Manchuria.

The ability of any country to engage in active commerce with other parts of the world depends fundamentally of course on the character and extent of its natural resources. It must be able to produce in quantity larger than is required by its own people, commodities which other peoples desire. In this respect there are enormous differences between the various regions which surround the Pacific. What these differences are can probably be best indicated by an examination of the export trade of the countries under review. Having made clear what it is that they are able to-day to produce in sufficient surplus to be able to sell abroad we shall be better able to form some judgment as to what part they may be able to play in the future trade of the Pacific.

The trade statistics of many of the Latin-American countries are too incomplete to give reliable figures of their trade, but for Mexico, Costa Rica, Chile, and Peru, at least, we may reach definite conclusions. For China, Japan, Australia, New Zealand, sufficiently reliable figures are available. For the Pacific States of the United States and for British Columbia, because of the fact already alluded to, that much of their extraterritorial trade is carried overland to regions under the same fiscal control as themselves, conclusions must be based on other evidence than that of official trade statistics which do not exist. 
For the countries for which relatively complete statistics are available the figures show the following:-

ANNUAL AVERAGE EXPORTS BY CLASSES OF COMMODITIES

Values in millions of dollars

\begin{tabular}{|c|c|c|c|c|c|c|c|}
\hline & $\begin{array}{l}\text { Forest } \\
\text { prod- } \\
\text { ucts }\end{array}$ & $\begin{array}{l}\text { Animal } \\
\text { prod- } \\
\text { ucts }\end{array}$ & $\begin{array}{c}\text { Agricul- } \\
\text { tural } \\
\text { products }\end{array}$ & $\begin{array}{l}\text { Mining } \\
\text { prod- } \\
\text { ucts }\end{array}$ & $\begin{array}{l}\text { Manu- } \\
\text { factures }\end{array}$ & $\begin{array}{l}\text { Miscel- } \\
\text { laneous }\end{array}$ & Total \\
\hline Mexico ${ }^{1}$ & I.3 & 6.0 & 30.6 & $69 \cdot 7$ & 0.2 & I6.4 & I 24.4 \\
\hline Costa Rica ${ }^{2}$ & 0.1 & O.I & $7 \cdot 3$ & 0.7 & $\ldots$ & O.I & $8 \cdot 3$ \\
\hline Chile $^{3}$. & 0.0 & $2 . I$ & 3.0 & 90.3 & I. 2 & 8.7 & $105 \cdot 3$ \\
\hline Peru 4. & $4 \cdot 4$ & 2.4 & $9.8^{8}$ & 5.0 & 0.9 & 6.0 & 28.5 \\
\hline China $^{1}$. . & $\ldots$ & $70.2^{7}$ & 6ז.8 & $\ldots$ & $34.6^{9}$ & $4 \mathrm{I} .9$ & 208.5 \\
\hline Japan ${ }^{3}$.. & 7.6 & $60.4^{6}$ & 10.8 & I9.9 & $58.9^{10}$ & $39 \cdot 3$ & I96.9 \\
\hline Australia ${ }^{1}$. & 5.8 & I72.4 & 39.0 & $93 \cdot 5$ & 3 I.I & 0.5 & $324 \cdot 3$ \\
\hline New Zealand 1 & 4.2 & 70.7 & 4.8 & 12.0 & I.O & 0.2 & 92.9 \\
\hline Philippines ${ }^{5}$ & ... & $\ldots$ & 30.3 & I. 3 & I.० & I.4 & 34.0 \\
\hline
\end{tabular}

1 I906-1910.
2 I907-I910.
8 I905-r909.
4 I906-1909.
5 I905-I908.

Includes: silk, 56.4 ; and fishery products, 4.0.

Includes: silk, 49.7; and fishery products, I.o.

${ }^{8}$ Includes sugar, $5 \cdot 4$.

9 Includes "medicines," I9.5.

${ }^{10}$ Includes: cotton yarn, I5.I; cotton tissues, 8.8; and silk tissue, I8.I.

Important differences between these countries will at once be noticed. In Mexico and Chile mineral products greatly exceed any other class, in the former constituting $5^{6}$ per cent. of the total and in the latter, 86 per cent. In China, Japan, Australia, and New Zealand, animal products predominate, making 34 per cent., 3 I per cent., 53 per cent., and 76 per cent., respectively, of the total export. Only in the Philippine Islands and Costa Rica do agricultural products exceed all other classes, the percentages in these 
cases being 90 and 80 respectively; but in China, Mexico, Peru, and Australia they are nevertheless important, making 30 per cent., 25 per cent., 34 per cent. and 12 per cent. respectively of the total. Nowhere do forest products rise into prominence except in Peru and even there they make up only 15 per cent. of the total. Manufactures play a very unimportant part except in the two most densely populated Oriental countries; China's exports being 16 per cent. of this sort, and Japan's, 30 per cent. There is this great difference, however, between the manufactures of these two countries that China's are almost wholly the products of small domestic industries while 70 per cent. of Japan's are the output of cotton and silk factories organized on modern lines.

Although, as already stated, statistics of the extraterritorial trade of the Pacific States of the United States and of British Columbia are not available in form to make them valuable for our purpose, yet the character of their products is such as to make it clear that in the export business they occupy a position very similar to that of the other sparsely populated regions of the Pacific. The exports of Canada as a whole are divided among the various classes as follows: forest products, 3 per cent.; animal products (including fishery products), 22 per cent.; agricultural products, 37 per cent.; mineral products, 14 per cent. ; manufactures, 24 per cent.; and miscellaneous products, a small fraction of one per cent. As less than five per cent. of the total capital invested in Canadian manufactures is employed in establishments in British Columbia, it may be assumed 
that the exports of manufactures from this region are negligible. British Columbia produces but 0.2 per cent. of the wheat, 0.1 per cent. of the barley, 0.5 per cent. of the oats, 4 per cent. of the potatoes, and $7 / 2$ per cent. of the flax of the whole Dominion. The agricultural exports of British Columbia cannot, therefore, be large. On the other hand, this province possesses 40 per cent. of the forest area of the Dominion, produces 27 per cent. of the huge fish output, and probably even a higher percentage of the mineral output. The chief exports, therefore, it is safe to say are lumber, fish, and minerals.

In the Pacific Coast States of the United States conditions are very similar except that there is a larger variety of products. These six States, Arizona, California, Nevada, Oregon, Washington, and Idaho have manufacturing establishments whose aggregate capital represents only 5 per cent. of the total capital so employed in the United States as a whole. Their products are mainly the output of the pastoral, agricultural, and mineral industries, and the forests. Together they support 24 per cent. of the sheep of the United States and supply 20 per cent. of the wool clip. They grow I 3 per cent. of the country's wheat, I8 per cent. of its beet sugar, and 26 per cent. of its barley. California is the greatest producer of fruit and wine in the country. Together they supply 37 per cent. of the country's gold, 43 per cent. of the silver, $3^{8}$ per cent. of the copper, $3^{6}$ per cent. of the lead, 47 per cent. of the petroleum, 87 per cent. of the quicksilver, and roo per cent. of the borax. Oregon possesses one-sixth of the standing timber of the nation, but 
the lumber resources of Washington and California are also enormous. The coast and river fisheries produce nearly 50 per cent. of the nation's fish supply.

The "money crop" of the region, therefore,-the things which it has to sell-consists of raw and semi-raw materials and foodstuffs, and economically it belongs in the same class with all the other sparsely populated regions of the Pacific Basin. They are all "young" countries in the economic sense and their industries are complementary to those of the "older" countries of western Europe. Even China and Japan, though their dense population puts them in a somewhat different class by giving them the latent possibilities of a more rapid advance into the "older" class of manufacturing nations, are still chiefly producers for foreign trade of raw and semi-raw materials and foodstuffs.

The specific commodities which this whole vast Pacific Basin is able to furnish for the markets of the world are very varied and naturally differ greatly in different portions of the region. Mexico's exports are $5^{6}$ per cent. metals, in which the largest items are silver (3r per cent.), gold ( 13 per cent.), and copper (ro per cent.). The next largest is textile fibers, making 12 per cent. of the total, five-sixths of this class being hennequin. Live animals and hides ( 5 per cent.) and rubber ( $3 \frac{T}{2}$ per cent.) are the only other large items.

Central America's exports consist chiefly of coffee (about $5^{6}$ per cent.), bananas (about 20 per cent.), gold and silver (about $4 \frac{1}{2}$ per cent.) and hides and skins (about 2 per cent.), with smaller quantities of hardwoods, rubber, etc. 
While Colombia has a variety of resources and sends abroad a considerable number of different commodities, the chief exports are made up of a very few items; coffee ( 36 per cent.), skins ( 9 per cent.), bananas (6 per cent.), and rubber (2 per cent.). Ecuador's foreign sales are even more concentrated into a few classes of goods. Sixty-two per cent. of her total exports are cacao; I4 per cent. ivory nuts; and 6 per cent. rubber.

Farther south on the American coast, mineral exports come into prominence again. Seventeen per cent. of Peru's exports are mineral, mostly copper (II per cent.). Bolivia's are 43 per cent. mineral, mostly tin ( 35 per cent.), and Chile's, 86 per cent., mostly nitrate ( 72 per cent.). Peru, however, furnishes also considerable supplies of other important articles. The largest single item is sugar, about $\$ 5,400,000$ worth per annum; while rubber, $(\$ 4,400,000)$, cotton $(\$ 3,600,000)$, and wool $(\$ 2,000,000)$ are also important.

On the opposite shore of the Pacific, as has already been stated, we find a different set of conditions. Australia and New Zealand belong in the same general class of countries as those already considered, sparsely populated, devoting their energies to a few predominant industries and purchasing their imports by the sale of the products of these few industries; while China and Japan with dense population and great variety of industries have a much larger list of export commodities. In Australia, 40 per cent. of the export is of the single commodity, wool. Wheat ${ }^{1}$ (I4 per

${ }^{1}$ Figures for ×9io. 
cent.) is the only other item which rises above 7 per cent. of the total. Wool, hides, fresh meat, butter, tallow, live animals, and leather, make up 60 per cent. of the total, and minerals (mostly gold) furnish 17 per cent. Wheat and flour together add another 15 per cent. These three groups together, therefore, make up no less than 92 per cent. of the total exports. In New Zealand conditions are not very different. Wool alone constitutes ${ }^{1} 3^{6}$ per cent. of the total export, while wool, meat, butter, tallow, hides and skins, live animals, etc., furnish 76 per cent. of the total. The remaining 24 per cent. is composed mainly of minerals (mostly gold) with 12.5 per cent.; phormium, 3 per cent.; kauri gum, 2.6 per cent.; and lumber, 2 per cent.

The trade of China and Japan with countries of the Atlantic Ocean Basin is largely of the same general character, though the item differs. Seventy per cent. of China's exports are made up of silk, beans and bean cake, tea, cotton, vegetable oils, sesame seeds, straw braid, and hides, skins, and furs. Most of the cotton and a large part of the beans go to Japan and cannot therefore be included among the goods with which purchases are made from Atlantic countries. Japan's export to Europe and the eastern United States is mainly silk and silk manufactures, though copper, tea, earthenware, straw plait, camphor, rice, matting, etc., are also considerable items. The growing export of textile manufactures (chiefly cotton), the output of modern mills, goes chiefly to China and other near by Oriental countries. In the Philippines there is an even greater con-

1 Figures 1906-10. 
centration in the list of export commodities. Ninety-five per cent. of the purchases from Europe and the United States are paid for by exports of five commodities- "hemp," copra, sugar, cigars, and tobacco leaf.

On the whole it is evident that the export commodities of the Pacific countries, in spite of the great contrasts between different sections, have this much in common-that they are goods which in the main are complementary to the products of the industrial regions of the Atlantic such as the eastern United States, England, Germany, France, etc. The Pacific Basin produces a surplus of raw and semi-raw materials and foodstuffs which its peoples are able to use in purchasing the surplus products of the Atlantic countries.

The character of the goods which the Pacific countries receive in exchange for their exports may also be indicated by a brief analysis of their import trade. For purpose of comparison, the imports may be divided into four classes; foodstuffs (including beverages, tobacco and similar luxuries), clothing and clothing materials (textiles, readymade clothing, boots and shoes, etc.), structural and industrial materials (such as are used in construction work and development of industries), and miscellaneous manufactures, etc. Taking the Pacific Basin countries as a whole, their imports at present consist of about I4 per cent. foodstuffs, 24 per cent. clothing, etc., 40 per cent. structural and industrial materials, and 22 per cent. miscellaneous manufactures, etc. Structural and industrial materials and general manufactures therefore predominate, together making up 60 per cent. of the total foreign purchases. And 
they are increasing in relative importance. If we compare the two five-year periods 1902-1906 and 1907-19II we find, for the countries whose foreign trade figures are sufficiently complete ${ }^{1}$ to make the comparison possible, that the following changes have taken place: foodstuffs have dropped from r6.3 per cent. of the total imports to 13.9 per cent.; and clothing and clothing materials, from 28.4 per cent. to 23.8 per cent. Meanwhile industrial and stuctural materials have risen from 37.7 per cent. to 40.4 , and general manufactures, from 17.6 to 21.9 . There is abundant evidence, although complete statistics are not available, that a similar tendency exists in the other Pacific countries.

\section{IMPORTS INTO PACIFIC OCEAN COUNTRIES. BY CLASSES}

Annual averages in millions of dollars

\begin{tabular}{|c|c|c|c|c|c|c|c|c|}
\hline & \multicolumn{2}{|c|}{ Foodstcrrs } & \multicolumn{2}{|c|}{ 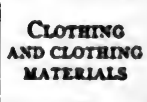 } & \multicolumn{2}{|c|}{ 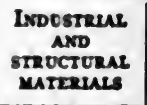 } & \multicolumn{2}{|c|}{$\begin{array}{c}\text { Mrscterna- } \\
\text { NeOOS }\end{array}$} \\
\hline & $\begin{array}{c}\text { Ist } \\
\text { per- } \\
\text { iod }\end{array}$ & $\begin{array}{l}\text { 2nd } \\
\text { per- } \\
\text { iod }\end{array}$ & $\begin{array}{c}\text { rst } \\
\text { per- } \\
\text { iod }\end{array}$ & $\begin{array}{l}\text { 2nd } \\
\text { per- } \\
\text { iod }\end{array}$ & $\begin{array}{c}\text { 1st } \\
\text { per- } \\
\text { iod }\end{array}$ & $\begin{array}{l}\text { 2nd } \\
\text { per- } \\
\text { iod }\end{array}$ & $\begin{array}{c}\text { rst } \\
\text { per- } \\
\text { iod }\end{array}$ & $\begin{array}{l}\text { 2nd } \\
\text { per- } \\
\text { iod }\end{array}$ \\
\hline Mexico. & 5.8 & II. 2 & 12.1 & 13.6 & 29.6 & 40.8 & $24 \cdot 3$ & 36.0 \\
\hline Costa Rica. & 1.0 & 1.0 & 1.0 & 1.5 & 1.0 & 1.5 & 2.4 & 2.9 \\
\hline Peru. . & 1.9 & 2.4 & 4.9 & 5.8 & 6.8 & 8.8 & 6.3 & $7 \cdot 3$ \\
\hline Chile.. & $3 \cdot 4$ & 3.9 & 9.2 & 12.1 & 16.5 & 38.0 & 21.9 & 36.0 \\
\hline China ... & 30.2 & 48.7 & 96.8 & 96.3 & $4 x .4$ & 49.6 & 28.7 & 75.0 \\
\hline Japan... & 33.6 & 31.6 & 11.7 & 17.0 & 77.7 & 129.0 & 22.2 & 39.0 \\
\hline Australia & 33.1 & 31.6 & 59.4 & $79 \cdot 3$ & 84.1 & 318.1 & 13.6 & 21.9 \\
\hline New Zealand. & 6.8 & 10.2 & 14.1 & 88.5 & 26.8 & 36.4 & 10.7 & 12.2 \\
\hline Philippines. & 8.8 & 6.8 & 8.8 & 8.3 & 4.4 & $5 \cdot 4$ & 4.4 & 1.5 \\
\hline Total & 124.6 & 147.4 & 218.0 & 252.4 & 288.3 & 427.6 & 134.5 & 231.8 \\
\hline $\begin{array}{l}\text { Percentage of total im- } \\
\text { ports.............. }\end{array}$ & 16.3 & 13.9 & 28.4 & 23.8 & $37 \cdot 7$ & 40.4 & 17.6 & 21.9 \\
\hline
\end{tabular}

${ }^{1}$ Mexico, Costa Rica, Peru, Chile, China, Japan, Australia, New Zealand, and the Philippines. 
These figures mean that on the whole the Pacific countries are passing through an economic transition. With certain exceptions which will be noted in the proper place, they are developing more fully their domestic production of foodstuffs and depending less on foreign supplies. This does not necessarily indicate, in most cases, that the actual quantity of foodstuffs produced is being increased, but it points rather to $a$ diversification of the industries, a growth in production of certain classes of food, particularly those which result from the more or less elaborate working up of the crude materials (such for instance as wheat) into partly manufactured goods (such as flour). Similarly with clothing and clothing materials the relative decline in the importation of such goods does not indicate that the people are using less or poorer clothing, but that a part of their industrial energy is being turned toward the home production of such goods. In nearly if not all the Pacific countries the chief clothing material is cotton and in a great many of them the first steps toward the introduction of manufacturing have taken the form of an endeavor to develop cotton factories by means of high protective tariffs. The result has been that except on the Pacific Coast of the United States and Canada and a few of the smaller unimportant tropical sections of the Pacific, the manufacture of cotton goods of the cheaper grades which make up the bulk of the clothing materials which the people use, has made sufficient advance to curtail the purchase of foreign supplies.

In short, wherever one turns in the entire list of Pacific Ocean countries there is found a striking tendency of devel- 
opment along roughly similar lines. They are all young countries in respect to modern industrial development. They are all engaged, more or less energetically, in developing their abundant natural resources whether they be the mineral and pastoral resources of Australia; the mineral deposits of South America; the minerals and fruits of Central America; the mineral or pastoral activities, or the textile manufactures of Mexico; the mineral, forest, agricultural and horticultural resources of our Pacific Coast States and Canada; the industrial resources of Japan; or the immense and various latent resources of the huge Chinese Republic. In the process of growth, as a necessary accompaniment and result of it, they are looking to the older industrial regions of the Atlantic Basin-to the eastern United States, to England, Germany, France, Belgium and other European States-for the needed capital and the immense quantities of highly specialized manufactures which the development of new industries demand-structural iron and steel, steel rails, locomotives, railway cars, bridge materials, galvanized iron, wire, agricultural machinery and implements, mining machinery, pumps, windmills, dynamos, general electric machinery and equipment, spinning and weaving machinery, hardware, tools, boilers, pipe, etc., a list which might be extended almost indefinitely. Alongside of this demand-which may be called the direct demand made by growing industries-is an accompanying indirect demand stimulated by more intimate knowledge of the products of the western worldfor articles which in a certain sense partake of the nature of 
luxuries: sewing machines, typewriters and calculating machines, bicycles, automobiles, writing paper, newspaper, printing presses, soap and other toilet requisites, patent medicines, perfumery, glass and glassware, rubber goods, furniture, household utensils, finer grades of textiles, millinery, etc., an almost infinite list of things few of which alone are important in international trade, but which in the aggregate play a considerable part in the sales of our industrial nations.

The general character of the interchange of goods between the Atlantic and the Pacific Coast areas is clearly indicated by the foregoing analysis of Pacific Ocean resources and the tendencies which Pacific Ocean trade has revealed in recent years. Whatever the ultimate commercial results of the opening of the Panama Canal may be, it is obvious that its first effects will be felt in connection with trade as it at present exists. The Pacific Ocean countries are sending to-day to the industrial countries of the Atlantic Basin, increasing quantities of foodstuffs, and raw materials, products of their mines, fields, flocks, and forests. With these exports they are purchasing in return, and also in increasing proportions, the multifarious products of American and European factories. The question to-day of prime interest to the industrial regions of the Atlantic is which of these Atlantic nations is going to be best able under the new conditions to supply the Pacific with these things which its peoples need. 


\section{CHAPTER IV}

\section{THE ATLANTIC COUNTRIES}

NINETy per cent. or more of the foreign trade of the two score of Pacific countries which we have been considering consists of an interchange of goods with countries in the Atlantic basin. Nearly every country whose shores are touched by the Atlantic takes some part in this trade, yet on the whole there is an astonishing concentration in the hands of a very few. In the export trade to Mexico, Central America, and Colombia, for instance, four countries, the United States, the United Kingdom, Germany, and France, hold 94 per cent. of the business; to the west coast countries of South America, the same four countries supply 93 per cent. of the total imports which come from the Atlantic basin. To China the United States, United Kingdom, Germany, Belgium, and Russia supply 96 per cent.; to Japan the United States, United Kingdom, and Germany, 94 per cent.; to Australia and New Zealand, the same three countries, 96 per cent. A similar condition exists in regard to exports from the Pacific countries; all but about 2 per cent. of their sales to Atlantic basin countries go to the United Kingdom, the United States, Germany, and France.

In attempting, therefore, to form an opinion as to the 
future trade between the Atlantic and Pacific it will not be necessary, except in a few specific cases which will be examined in the proper place, to consider as competitors on the Atlantic side any but these few countries. How are these countries situated in respect to their ability to supply to the Pacific lands the goods which the latter are demanding?

All four of these countries are among the great exporters of manufactured goods, but thus far England maintains the lead. No less than 80 per cent. of the huge export of the United Kingdom belongs to this class. Germany comes next in this respect with over 70 per cent. and France is not far behind with $5^{6}$ per cent. The United States has not yet reached such eminence in the export of manufactures, yet this class of goods is assuming a position of great importance. Including manufactured goods ready for consumption and partly manufactured articles for further use in manufacturing, but excluding prepared (manufactured) foodstuffs, the percentage reaches 45 . In absolute figures these exports of manufacturers reach enormous totals; in England \$I,8II,000,000; Germany \$I,200,000,000; France $\$ 680,000,000$; in the United States $\$ 907,000,000$. The grand total for these countries, $\$ 4,598,000,000$, exceeds the exports of the same class from Belgium, Holland, Spain, Portugal, Austro-Hungary, Russia, and all the remaining smaller countries of Europe, six or sevenfold. In regard to the United States it should be noted that the estimate of the relative importance of manufactures stated as above in terms of percentage of total exports is somewhat mis- 
leading, for it fails to recognize the preponderance of manufactures in certain sections. Fifty per cent. of the mechanical power employed in manufactures in the entire country is so used in the New England and Middle Atlantic States. If we add the North Central States this percentage is raised to 78 . In the vast region west of the Mississippi, manufacturing is insignificant. If reliable statistics were obtainable of the exports of goods originating in the Atlantic seaboard States alone, those States which belong unquestionably to the commercial basin of the Atlantic, there can be little question that the ratio of manufactures to other classes of export goods would rise far beyond the 45 per cent. figure for the country as a whole: it would probably reach seventy or eighty per cent.

The relative position of different classes of manufactures in the exports of these four countries is far from being uniform, however. For England 24 per cent. of the total export of manufactures is of iron and steel products and 56 per cent. of textile goods. German export of manufactures is: 25 per cent. of iron and steel, 18 per cent. of other metals, 32 per cent. of textiles, and in per cent. of chemical products. French exports of manufactures are made up chiefly of textiles, articles de Paris, etc. (46 per cent.) and sundry finer grades of what may be called fashion goods. Iron and steel products do not exceed 8 per cent. The United States presents a contrast to all of these. Although textiles stand second in importance among our manufacturing industries (being exceeded only slightly by iron and steel in value of product) they play an insignificant part in 
our export trade in manufactured goods-less than 5 per cent. Iron and steel occupies first place with about 30 per cent. of the total; other metals such as copper (I4 per cent.) occupy second place, while refined oil, leather goods and manufactures of wood make up another 29 per cent.

The relatively unimportant position of France as an exporter of iron and steel products makes it probable at least that her position as a competitor of Pacific trade will decline rather than increase. The strong demand from the western ocean for goods of this particular sort will be likely to bring the United States, England, and Germany even more prominently to the fore as monopolizers of the market. Each possesses certain well-defined advantages in the competition which deserve examination.

In the United States we have a country young and vigorous; one which although still predominantly an agricultural country, has within the last decade or two made marvelous strides in manufactures, until she now ranks as the largest producer of many of the commodities which are in strong demand in the markets which we are considering. Not only are we producing, we are also exporting to such an extent as to put us in the front rank of commercial nations, but to this latter position we have only recently attained. We were large producers long before we were large exporters, and even now, in spite of the enormous growth of our sales abroad, our home markets, until recently protected by a high-tariff wall, remain far more extensive and far more valuable than our foreign. It must be a promising field indeed which tempts an American manufacturer of any particular line of goods 
to make much outlay of time or money for the capture of foreign markets, so long as easy, safe and profitable sales are possible at home. This is a truth often lost sight of, but one which it is essential to recognize before we can make any progress in the understanding of our treatment of foreign markets. The reluctance on the part of American producers to seize what appear to be opportunities for foreign trade must not be charged to any lack of perception or energy. The immense success which they have obtained in home markets, and in those foreign markets to which they have given serious attention, confirms their worldwide reputation for skill and farsightedness. But before they bring these qualities to bear in a campaign for new markets, they must be convinced that the new course is better worth while than the particular one they are already pursuing.

In England we find, in many respects, the very reverse of American conditions - an old country, the pioneer of modern manufacturing, dependent upon her foreign sales of the products of her factories for the very food she eats, long accustomed to pre-eminence in the output of many lines of goods and the control of almost any market which she cared to enter; confident, at least until recently, of the stability of her commanding position, and imbued with a conservatism of method due largely to her long-continued success. Her home market is, of course, immensely valuable, though open to inroads from abroad through the absence of a tariff barrier, but neither in character nor amount is it relatively so important to herself as the home 
markets of the United States are to Americans. The strength of her position lies largely in the relative importance of her foreign markets and in what we may call her vested interests in those markets. The fact that as an exporter she has shown some decline relatively to Germany or the United States must not blind us to the fact that she still holds a commanding position in many important respects.

In Germany, France, Belgium, Spain, Portugal, etc., we find conditions which stand between those existing in the two extremes, America and England, but while the four last-mentioned countries may be regarded as approaching the class of which England is the type, Germany approaches the type represented by the United States. It is a young and progressive country economically; has roused itself in recent years, and is energetically and persistently struggling to capture foreign markets. It, of course, differs widely from the United States so far as concerns the relative value of its domestic market, but it must nevertheless be regarded as belonging to the same general class, because it displays the same spirit of energy and adaptability, and because it, with the United States, is an attacking party in attempting to drive England and other possessors of the market from their commercial entrenchments. Many minor differences, of course, exist between the various competitors, and the above classification can be accepted only in the broadest outline.

A rough measure of the latent ability of the United States, England and Germany, to compete in foreign markets may 
be found in their power to produce the classes of goods demanded there. The fundamental requisites are of course capital, labor, raw materials, and power. The United States has a population approximately equal to that of England and Germany combined, and it is increasing far more rapidly than theirs. In the decade 1900-1910 our census figures show a growth from $76,000,000$ to $92,000,000$ or over 2I per cent. From rgor to Igri the number of inhabitants in the United Kingdom rose only 9.I per cent. and in Germany from 1900 to 1910 , only 15 per cent. There is every reason to expect that this more rapid growth of the United States will continue; the country will become progressively more thickly populated and have an increasing labor force to be applied to manufacturing industry.

Manufactures to-day depend also fundamentally on three sources of power: coal, oil, and water power applied either directly or through conversion into electric energy. American output of coal to-day is not far short in quantity of the amount produced by England and Germany together and is rapidly increasing. Neither England nor Germany possesses any considerable quantity of fuel oil. If they use this fuel for manufacturing purposes they must import it. The United States, on the other hand, is by far the largest producer of this mineral in the world, supplying about twothirds of the total. While approximately one-half of this is used for purposes other than for fuel, the amount applied for the production of power, with the immense output of natural gas as well, probably equals in power equivalence 
over $50,000,000$ tons of coal, thus materially adding to an already enormous supply of fuel.

In water power also the United States is highly favored as compared with either England or Germany. The former uses large quantities of power of this sort in the aggregate, but the total amount not only falls far short of the amount at present used in the United States, but there is not much possibility of further large development. German water possibilities are mainly confined to the southern portion of that country where considerable development has taken place, yet even here neither the present use nor the opportunity for further exploitation compare with those in the United States. In the United States, probably 20 per cent. of the $15,000,000$ horse-power employed in manufacturing industries, is derived from water power and the possibilities of further development, especially in the mountain regions, seem almost unlimited.

Of the raw materials for manufactures it seems hardly necessary to speak, so well known is the pre-eminence of the United States in the supplies of many of the most important of them. Of the most important textile fiber, cotton, the United States produces within its own borders over 60 per cent. of the world's supply. In wool we produce more than twice as much as Great Britain and six or seven times as much as Germany though both of these countries have the advantage in being near the great European sources of supply for what they need in excess of their domestic product, while the United States must get what it imports from distant lands. The lumber resources of 
the United States, of course, are many times as great as those of England and Germany.

In regard to the metal industries, no country of the world is to-day so well supplied with materials. Others, such for instance as China, may possibly have greater resources of this kind, but they still lie dormant. The iron ore production of our country reaches 38 per cent. of the world's total and is nearly equal to that of England and Germany combined. Our pig-iron output goes even higher, rising to 43 per cent. of the world's total and considerably exceeding the production of England and Germany together. In copper, lead, zinc, and several other metals, important in modern manufacture, we also either hold a virtual monopoly of the world's supply or greatly exceed the resources of our European rivals.

With advantages such as have been mentioned above, it is not surprising that the United States has reach ad a position which opens to it the possibility of entering seriously into the competition for markets in foreign countries. We are already the greatest producer in the world of many of the important manufactures which may be regarded as entering into world commerce. Our factories consume a larger quantity of cotton, and of wool, than those of any other country. Our silk factories use nearly twice as much raw silk as those of England and Germany together, and 50 per cent. more than those of France. Our production of steel comes within a few per cent. of equalling that of all the rest of the world; it is 50 per cent. greater than that of England and Germany together. The list of specific 
manufactures in whose production we lead the world would be tedious to enumerate. It includes agricultural machinery and implements, railway equipment of all sorts, wire, automobiles, copper manufactures, leather goods, clothing, rubber goods, hardware, tools, structural iron and steel, all sorts of calculating, registering, and writing machines, pumps, pipes, windmills, printing presses, boilers, etc. The fact that our domestic market for these things has been so overwhelmingly important as to hamper the development of our export of them, leads us often to overlook the fact that our production is so pre-eminent. As a nation we have devoted little energy to the capture of foreign markets for these manufactures, because it has not yet seemed worth while. Now, however, conditions are changing. The filling up of our country, and the demands of our industrial population for foodstuffs, are decreasing our power to export our breadstuffs, provisions, and dairy products. More and more do our factories make claim to our various industrial raw materials and demand the importation of others. We are forced to look more seriously to the possibilities of selling manufactures to the foreigner in exchange for the things which we require from him. The downward revision of our import duties operates both to stimulate and facilitate this movement. In so far as it makes possible the importation of foreign manufactures, it tends to force our own manufacturers to seek a wider market for their products abroad. In so far as it reduces the cost of imported raw materials, it places our factories on a more even footing with European factories in the matter of cost of production 
and gives them a better chance to compete in neutral markets. In turning our manufacturers' attention towards the need of cultivating foreign connections it tends to force them to realize the necessity of good packing, proper invoicing, prompt deliveries, suitable credits, etc., and discourages the pernicious habit of regarding foreign markets merely as a convenient dumping ground in times of glut in the home market.

In respect to these points just mentioned, as well as several other important ones, the position of both England and Germany is at present far stronger than ours. In the care with which they cultivate the export trade, their close attention to details of demand, the character of their agents, the organization of their methods, they are far superior, on the whole; and they have further advantages in such things as banking and shipping facilities.

It is a well-known fact that there are few American banks in any of the Pacific countries while there are many European ones, especially English and German, and our consular reports abound in statements that this lack constitutes a serious handicap to American trade. Yet there are good reasons for believing that our disadvantage in this respect, although it may exist, has been grossly exaggerated.

So far as the actual settlement of balances is concerned - the strictly banking part of the business-it is difficult to see how the nationality of the bank cuts any figure. Most settlements are made by the familiar letter of credit system under which the exporter, say in Liverpool or New York, in shipping his goods to the Pacific country, draws 
at from ninety to one hundred and twenty days on the London account of the importer's bank, and then discounts his draft at his own bank; and it is a matter of complete indifference to him whether the importer's bank which arranges the London credit, is American, French, German, or English. Nor is the importer at the other end interested in the matter; he will get his London credit from any bank that offers him the best facilities, and there is no reason to suppose that an American bank would be in any better position to give such facilities than any other bank.

Another large class of trade exchanges, in dealings with specific countries, are settled by large exporters and importers who themselves conduct a sort of disguised banking business. Where a large concern both imports and exports, or where there are allied concerns, some exporting and others importing, it is in many cases cheapest and simplest for them to arrange for settlements which do not call for the services of a bank proper, at all. Such a method is employed, for instance, in a considerable share of the trade with South America, and where it is employed, the dealers are, naturally, not concerned with the existence or nonexistence of American banks.

In some transactions, but they are usually the smaller ones and their aggregate is probably not large, the exporter in New York may draw directly on his consignee and negotiate his draft at his own bank; or the importer in the foreign country may make his payment by London or New York draft purchased at his bank and forwarded either with his order or upon receipt of the goods. In the former case 
the presence or absence of an American bank in the importer's country obviously plays no part in determining what the exporter will get for his draft; and in the latter there is no reason to suppose that the importer could buy a draft any more cheaply from an American than from a European bank.

So far as concerns the mere banking transactions, therefore, there seems to be no reason to suppose that an American bank in the countries with which we are trading could offer any better facilities or any more favorable methods of settlement than those given by other banks. Yet there are other services performed by banks or by individuals in banks, not strictly connected with the banking business proper, in regard to which the case may be different. Banks are the chief and most reliable source of commercial and credit information. They are in a position to know the financial standing of business houses and to get early "tips" as to large transactions such as the floating of loans for public improvements, etc. A German bank with branches in Chile or Japan is in a somewhat better position to give information of this character to its clients than an American bank with no such connections, and the result is that the German exporter is probably in a better position to give credit to his foreign customer and the German capitalist has earlier advice as to foreign investments. The American exporter's unwillingness to grant long credits to purchasers and the large European capital investments in many Pacific enterprises unquestionably does hamper our trade to some extent. 
There-is also a certain psychological element which deserves mention: the lack of American banks, like the absence of American steamship lines, seriously reduces the commercial prestige of the United States. The mass of the people particularly in the Latin-American countries, do not understand why it is that a country which claims to be one of the largest of exporting nations, can be so backward in banking and shipping, which to the popular mind seem to be all-important manifestations of greatness and power. Argument is useless. The foreigner is convinced that the United States cannot be commercially as great as England or some of the continental countries-if she were she would have banks and ships as they do-and there is created a certain tendency to regard trade connections with them as more desirable than those with the United States.

Another important question which arises in connection with the relative strength of Europe and the United States as competitors in Pacific markets is the influence on our trade of the relatively inferior steamship service between the ports of the United States and those of the western ocean. It is an old question, one to which much attention has been given for years past; and in nearly every discussion of it the conclusion has been either assumed or deduced that the inferiority of the service is a serious handicap to our exporters, and that the establishment of direct lines of large and fast steamers would bring an immediate and enormous increase in our export trade. There are, however, grave reasons for doubting whether such an improvement 
in the service would cause any large results of the sort predicted.

Many of the largest and most experienced importers in the Pacific countries, men who deal in goods from both the United States and from Europe, are inclined to ridicule the idea that American exporters are in need of greater facilities. They claim that they never have any serious difficulty in getting all the goods that are demanded from New York quite as readily, allowing for differences in distances, as from London, Liverpool, or Hamburg, and that the steamers are smaller and the service poorer because there is little freight offering, and not vice versa. And the experience of those countries that control the bulk of the transportation to the Pacific is confusing. The statistics show that in the past ten years some of the countries of Europe which have made the greatest effort to stimulate steamship facilities between their ports and those of the Pacific have been the least successful in holding the trade.

It is a notorious fact that the tonnage of American shipping engaged in foreign trade has been steadily declining until now about 92 per cent. of our exports and imports are carried in foreign bottoms. It is also true that relatively few regular lines under any flag run between the ports of our Atlantic States and the countries of the Pacific Basin. Our government has done little if anything to assist the establishment and maintenance of such direct lines while several of the European nations have found it advisable directly or indirectly to favor connections between their ports and the Orient, South America, and Australasia. 
England, mainly for the purpose of maintaining frequent intercourse with her colonies, and Germany for the avowed purpose of stimulating commerce, have been particularly active in this respect. Yet the statistics of trade development of recent years are far from showing that the efforts toward maintaining direct, regular, and frequent service have really had as great results as anticipated. Comparing the two five-year periods I897-I90I and I907-I9II the figures reveal the fact, not commonly recognized, that on the whole the United States, in spite of the relative lack of shipping facilities, has made greater gains in her exports to Pacific markets than either England or Germany. To Central America and Colombia we sent in I897-I901 37.5 per cent. of all the goods which those countries bought from the great commercial centers of the Atlantic in North America and Europe; in I907-I9II our share had risen to 40.6 per cent. Meantime England's share dropped from 33.3 per cent. to 30.4 per cent., and Germany's increased only from I0.4 per cent. to I3.I per cent. To the west coast countries of South America we increased our percentage from I4.I to I9.4 while English trade declined from 43.6 per cent. to 40.6, and German, from 25.9 to 24.4. In Australia and New Zealand we increased our exports from I4.2 per cent. to $15 \cdot 3$, while Germany increased hers from 6.3 to 7.0 and England's trade dropped from 75.3 per cent. of the total, to 73.5 per cent. To Japan also, England's share in the trade declined from 49.0 per cent. to 45.4 , while Germany's increased from I5.4 per cent. to I9.5, and ours from 26.8 to 29.0. In China, all three countries suffered a decline 


\section{THE PANAMA CANAL}

in their share of the total but Germany's loss was proportionately much larger than that of either the United States or England. Our share dropped from 23.9 to 22.3 per cent., and England's from 50.3 to 48.2 per cent., while Germany's share which in the earlier period was 13.2 per cent. declined to $\mathrm{II} .8$ per cent.

In the face of such figures it is far from safe to assume, without further evidence, that the establishment of direct lines of steamers from the United States to Pacific countries would have results commensurate with the expense involved; and a more complete analysis of the situation becomes necessary. The question is a complicated one, but it readily divides itself into two considerations-the influence upon American trade of ( $\mathrm{r}$ ) the lack of transportation facilities and (2) the lack of passenger and mail facilities. And these two must be considered separately.

First, then, is there an insufficiency in the amount of freight accommodation offered to American shippers to the Pacific, or does the irregularity of sailing and the uncertainty as to exact date of arrival place any serious obstacle in the way of our exporters?

The opinion of men who have had actual experience in the countries in question in importing goods both from the United States and from Europe, is that there is in general sufficient freight space constantly offering to regular shippers from the United States, and that the rates are as low as could be expected in view of the smaller amount of our exports compared with those of Europe and the greater distance to most of the Pacific countries from New York 
than from European ports. For smaller shippers, attempting to build up new connections in the Pacific, the lack of direct and frequent service is probably a much more serious matter. Their shipments are not large enough to warrant the chartering of "tramps" nor regular enough to make possible the definite reservation of space in such vessels as do run. Often, if they would fill orders with reasonable promptness they must resort to round-about routes involving transshipments in order to get their goods to market. A small shipment, for example, from New York to China, unless the goods be sufficiently light and valuable to bear the high freight of the combined rail and steamship route across America and the Pacific, is more than likely to go first to England or Germany for carriage in an English or German vessel. For business involving these smaller shipments, and the aggregate is large, there can be no question that direct steamship connection would stimulate our trade. There is no evidence, however, that the nationality of the carrier is of any consequence whatever in regard to freight rates or facilities for transfer of goods. Neither the importer nor the exporter is concerned in any way with the color or the design of the flag under which his goods are carried.

The question of the frequency and regularity of mail service and passenger service is allied to that of freighting facilities and yet is quite distinct from it. In this respect also the service from the United States is inferior. The results of this inferiority depend upon the size and nature of the particular business affected. Large wholesale dealers 
and commission men who import in considerable quantities at a time, and whose orders are usually for standard grades of goods, probably suffer little inconvenience. Their orders go by cable and are thus independent of the mails, and by timing them carefully they can get the goods shipped promptly from the United States on one of the steamers whose service is regular and certain. With smaller dealers and smaller orders, as well as in all larger orders where full and specific instructions have to be given as to sizes, shapes and weights, and grades of goods, the mails must be used, and there are many complaints as to the inadequacy of the service. In many instances it takes much longer to get such orders from the United States than from Europe. As the United States is entering a comparatively new market, in competition with older countries whose goods have been long established in the field and have fixed themselves in the esteem of the people, a great deal of her trade must be in commodities of the sort just mentioned, made and shipped in such fashions as to conform with the customs and prejudices of a market already established by her rivals. Consequently, in a considerable part of our Pacific trade the mails are an important factor, and there can be no doubt that many orders which might otherwise go to our manufacturers go to Europe instead.

In still another respect the steamship service of the United States is inferior-except between San Francisco and the Orient there are no direct lines of large, fast passenger steamers plying between the United States and the Pacific. The Pacific countries are too little known in our country; 
a closer knowledge of their peoples and their wonderful resources would be a powerful stimulus to commercial relations. But under present conditions the traveling public desirous of first-class accommodation have to go to many Pacific ports via Europe at an additional outlay of time and money and the annoyance of a transfer to a new steamer in the European port. Good service on direct lines running from New York would induce many of our business men and capitalists to make holiday excursions to the Pacific, and personal knowledge of the possibilities lying dormant there would bring tangible results in the form of investments or stimulated trade.

On the whole, then, the superiority of European steamship service does operate adversely to American trade interests. So far as mere freighting facilities are concerned the handicap is one that is likely to remedy itself with time; for, in general, as trade develops, vessels will be found to carry it, especially that large class of traffic which prefers to make use of chartered or "tramp" vessels. As to mail and passenger service, a somewhat greater outlay for mail contracts would probably go a long way towards improving matters. The nationality of the carriers is a point of very minor importance. As in the case of the banks, above mentioned, the influence is a psychological one. There is a general consensus of opinion that the mere appearance in Pacific ports of steamships carrying the American flag would help convince the people that American trade connections are worth cultivating. At present our flag is seldom seen except on an occasional warship, or private yacht, 
or an out-of-date sailing vessel. The mass of the population in many of the lands have but the dimmest notion of the vast economic activities of our people. The markets are peculiarly sensitive to notions of fashion and prestige and most of the population-all except the very few who have traveled in the United States-have exalted ideas as to the greatness of England, France, and Germany, and the "fashionableness" of using commodities produced in those countries. There can be but little question that these impressions are deepened by visible illustrations of the superiority of European merchant marine.

Many sweeping assertions have also been made, from time to time, as to the inferiority of the methods employed by the exporters of the United States to introduce their goods into new markets, and the subject is of such importance as to demand somewhat extended examination. Like all other questions thus far considered, this is a complex one, and general statements are apt to be misleading, for the excellence or the inadequacy of any particular method of doing business obviously depends upon the nature of the commodities involved, the size of the trade, the credit of exporters or importers, and, to a certain extent, their nationality. The various methods employed may be summarized as follows:

(I) Many firms are content with the mere sending out of circulars, either directly to importers or through the consulates. In some cases these circulars are translated into the foreign language, and the weights, measurements, etc., given in terms of the local system. In the majority of 
cases, however, even this slight attention to the peculiar needs of the particular market is omitted; the circulars are printed in English, and the English system of weights and measures used. In any case there cannot be the slightest doubt that the sending of circulars, in the vast majority of instances, is utterly useless, and results only in the waste of postage and stationery. Some of the old-established exporting firms, whose brands of goods are already well known in these markets, may possibly be able to employ circulars with a little success, but such established firms are mainly English and European. For Americans, with one or two insignificant exceptions, mere advertisement is of no value whatever.

(2) The sending out of ordinary commercial travelers. Here again the "prestige" which certain classes and "nationalities" of goods enjoy in the markets, plays a most important part. The American traveler, as a rule, even if he is as well equipped in every way as his English or German competitor, is handicapped. The markets are peculiarly conservative both as to the character of goods demanded and the introduction of any novelties of method, and the casual American traveling agent can make but little headway. This would be true even if the American travelers were, as a class, as efficient men as those sent over from Europe. As a matter of fact they are by no means so efficient. The best of such agents are undoubtedly the Germans, and the shortcomings of the Americans can perhaps best be illustrated by describing the merits of these rivals. In the first place, the best men are expert linguists. They can con- 
verse with equal fluency in English, German, French, Spanish, and other languages. In too many cases American agents attempt to deal with foreign importing houses by employing interpreters. The difficulty of such a method needs no comment. In the second place, the best German agents are technical experts in the lines of goods which they represent. It should always be remembered that American exporters, like the German, are the attacking party in the competition for foreign markets. The field has for many years been in the possession of the English and to a less degree of other Europeans, and the newcomer is obliged to meet long-established customs and prejudices. This he can only do by catering in all minute details (many of them seeemingly absurd) to the peculiar tastes of his customers. To do this properly the agent must know exactly what his principal can do in the manufacture of new grades, sizes, weights, shapes, and colors of goods, or in changes in manner of packing. He must be able to figure accurately what each innovation will cost his firm, and what prices he can therefore quote. In far too numerous instances an American traveler, after getting an order by dint of long persuasion and by agreeing to have some slight change made in the goods, has had his agreement with the importer repudiated by his principal. The annoyance and delay caused to the importer by a single case of this sort may undo all the good accomplished by months of patient effort.

To get men of this caliber is not altogether an easy matter, and of course the inducements offered in the way of salaries must be considerable. Men of this class sent out 
by German firms are paid as high as $\$ 300$ or more per month, plus a commission on their sales, and are allowed traveling expenses without specific limit. It unfortunately seems to be the rule that American exporters are unwilling to incur so great expense as this. They send cheaper men and get inferior service. It should be added, however, that a change is at present going on in this respect, and some of the very best men in the field are working in the interests of American firms. It is greatly to be hoped that all of our exporters will realize the utter futility of sending any but the most efficient travelers even if the expense does seem large at first. If the trade is to be captured at all it must be at the expense of a good deal of time and money.

(3) The usefulness of the ordinary commercial traveler, no matter how thorough his equipment may be, is, however, confined to those lines of export trade in which well-known brands of goods are involved. So far as American export is concerned these classes of goods are rather few in number, for, as already mentioned, a large part of the trade is already in foreign hands. The introduction of new goods absolutely requires the continued presence in the markets of agents whose duty and interest it is to push sales persistently and patiently. These men must know the language and the people, their customs, prejudices, and peculiar tastes; they must advertise, display, and even distribute samples of their goods. They must be always on the spot to demonstrate the superior quality or cheapness of the articles they are seeking to introduce. If it be a bit of new 
machinery or similar article, they must be able to give instructions as to its use, or to make repairs if necessary.

There are several conceivable ways of meeting the requirement of having resident agents on the ground, and there are three chief methods employed-the appointment of some resident firm as a simple "agency," the appointment of a local firm as a "sole agency," and the sending out from home of a special resident agent. The first of these seems to be open to very serious abuses, which, in many cases, at least, render it almost useless. There are well-known cases in which firms advertise extensively as agencies of American houses and actually have appointment as such, without making the slightest apparent effort to push American goods. So great are the difficulties of long-distance supervision that our exporters who rely on this sort of representation are taking many chances and cannot be at all certain that their goods are given fair backing.

A "sole agency" plan by which the agent not only becomes the sole representative of his principal, but also agrees to sell no other goods of the same sort, is open to less serious objection; but it serves its purpose better for European than for American goods for the reason already alluded to, that our products are, many of them, comparative novelties on the market, and more persistent and undivided effort is required for their introduction. The best method of all, therefore, is one which has already been adopted by a few of our larger manufacturers; the sending out of special resident agents whose sole business it is to introduce their goods and who enter into agreements not 
to sell other articles or engage in other trade. If the home concerns are not strong enough to bear the expense alone, several of them, manufacturing entirely different sorts of goods, sometimes combine to support an agency, and this method, though open to some objections, seems to meet with considerable success. And in either case, whichever of the two last-mentioned plans be adopted, the advantage of having in the field a man who thoroughly knows his customers and at the same time is devoted to the interests of his principals is very great. In the matter of arranging credits alone it is almost indispensable. In many of the markets, there is absolutely no possibility of doing any large business on the cash basis, and credit can be allowed only with the utmost caution. Men who have had longest experience in the field emphasize this point most strongly. After decades of residence they find themselves making losses through misplaced confidence, and resort to the courts involves expense and delay which are generally prohibitive. A resident agent, always on the alert and having direct access to the principal source of information (the banks), can do much to lessen the risks.

The chief reason for the inferiority of American methods of placing goods in the markets is unquestionably our general inexperience in this sort of business. For a hundred years the United States was largely an exporter of bulk goods-foodstuffs and raw materials-which in a sense sold themselves. Our recent advance to a position as an exporter of highly manufactured goods to markets in which the names and products of our factories were unknown, 
has introduced an entirely new element into the problem. Such goods, until they get established, do not sell themselves; they have to be sold, and persistent effort is necessary if they are to get a real foothold. During the past twenty years in which this transition has taken place, the need for a foreign outlet for manufactures has made itself felt but spasmodically, in times of depression in the usually far more valuable home market. In such periods our manufacturers have shown much cleverness in placing goods abroad and have often succeeded in making large sales. But foreign trade does not really thrive on this spasmodic "dumping." We procure temporary purchasers for our goods, but we do not create "customers," and often when a new foreign connection has been made under stress of dullness at home, and then abandoned in a year or two when domestic business was brisk, the final result has been harmful rather than helpful to American interests in the foreign market.

What has been said concerning methods employed by American exporters for placing their manufactures in foreign markets applies equally to their shortcomings, so frequently emphasized by our consuls, in the matter of packing, invoicing, granting of credits, attending to minute instructions as to details of orders, etc. It is inexperience coupled with a certain amount of indifference, and not any lack of adaptability, which lies at the root of the difficulty. In those cases where Americans have seriously and persistently gone out after a foreign market they have easily equalled or surpassed the best methods of their 
European rivals. One has but to recall the success of such concerns as the Standard Oil Company, the Singer Sewing Machine Company, or the International Harvester Company, to dispel any doubts he may hold as to the American's ability to compete in foreign markets, as soon as he is convinced that it is worth his while to do so.

From this sketch of conditions in the three chief countries which have played and are likely to continue to play the predominant part in trade with the Pacific countries it will be evident that, on the whole, the United States is inherently in a position to compete vigorously with her rivals. In resources, in the production of the chief classes of articles which the Pacific regions demand, we stand already at the top, and although it is true that in respect to certain facilities and certain details of method, we are less favorably placed than either England or Germany, yet these disadvantages are of such a nature that there is every reason to believe that they may readily be eliminated. It would be a mistake to hold back merely because of certain relatively unimportant unfavorable circumstances. A vigorous attack on the markets would in itself go a long way toward creating the needed improvements. 


\section{CHAPTER V}

\section{RECENT TRADE MOVEMENT}

IT will be seen from the data presented in the preceding chapters that in the interchange of goods between the Atlantic and Pacific Ocean Basins, the exporters and importers of the eastern seaboard of the United States have been laboring under something of a disadvantage compared with their European rivals. Not only have the obstacles to cheap and quick delivery of goods to many of the Pacific countries been greater, but certain elements in our economic conditions have kept us from entering in whole-souled fashion into the competition and have hindered the development of the best trading methods. Before attempting to form any opinion as to what the new facilities offered by the Panama Canal may or may not do to change the currents of trade, it will be helpful to inquire how, under present and past conditions, those currents have been running.

In investigating such a question, it is necessary first of all to divide it into two parts. Owing to the fact, already alluded to, that no satisfactory figures exist as to the movement of goods overland between the two seaboards of the United States or Canada it is impossible to determine in any really adequate statistical way, how the various com- 
petitors for the trade of the Pacific coasts of either of these countries, have been faring. It would be impossible, for example, to get definite figures as to the total value of goods from Germany or England used by the people of California. Such goods only as are entered through the California customhouses would appear in the statistics for that State. Such conclusions as it is possible to draw as to the relative positions of England and Germany in these markets must consequently be based on other data. With regard to most of the other Pacific countries, however, it is possible, by using the statistical trade publications of the United States and the nations of Europe, to get fairly clear impressions of what the significant movements of the past ten or fifteen years have been. It is proposed, therefore, to examine the trade of these other Pacific countries first and postpone for the present the discussion of the Pacific coasts of the United States and Canada.

The chief countries of the Pacific Basin, outside the United States and Canada, are, as has already been stated, Chile, Bolivia, Peru, Ecuador, Colombia, Central America, Japan, China, the Philippine Islands, Australia, and New Zealand. ${ }^{1}$ These countries naturally fall into rather definite groups, more or less homogeneous with respect to important geographical, economic, and political conditions. Mexico, the Central American States, and Colombia all possess this in common, that their political and social characteristics are

${ }^{1}$ Minor countries like the more eastern East Indies, Hawaii, Samoa, Tahiti, Fiji, Alaska, etc., might properly also be included, but their trade is relatively small and their inclusion would introduce so many complex but unimportant details, that it will be best to omit them from consideration. 
somewhat similar and that, owing to the fact that they front on both oceans, the results to them of the opening of the canal are apt to be indirect rather than direct. Their trade will be stimulated, not so much because their prin-, cipal ports will be made more accessible, as because great trade currents will pass near their doors. Mexico, however, differs essentially from others in this group because of its peculiar geographical relations with the United States. The economically most important parts of this country being a high plateau, with difficult approaches to either ocean, but with easy overland access to the great railway systems of the United States, the commercial connection with the latter country is peculiarly close. It seems advisable, therefore, to consider Mexico separately.

The South American countries whose commercial frontage is on the Pacific-Ecuador, Peru, Bolivia, and Chilemay also be treated as a single unit, because, in the main, they all fall so definitely within the zone of the canal's influence. Before the canal was opened, a considerable percentage of the freight movement between Ecuador and the United States and Europe used the Panama route, being transshipped by rail across the isthmus; but farther south along the coast this route played a smaller and smaller part and the proportion of freight moving through the Straits of Magellan rapidly increased until at the southernmost Pacific ports, such as Valdivia, the Panama route entirely disappeared as a competitor.

When the canal is in full operation these conditions will be greatly changed. It is safe to say that nearly all the 
traffic between the Atlantic seaboard of the United States and these west coast countries will take the Panama route; and that a large part of the European freight movement will follow the same course except some of that which is destined for southern Chile. The opening of the canal will, therefore, effect so profound a change in the commercial relations of all four of these countries that they may reasonably be treated as a single unit.

China, Japan, and the Philippine Islands, while in many respects similar in possessing those social and economic characteristics known as "Oriental" and in lying along the border line between the zones of influence of the Panama and the Suez Canals, yet present so great contrasts in political and commercial development that it seems best to consider them separately. The sudden emergence of Japan from political and economic obscurity into commercial prominence among the nations of the world would alone be sufficient to put her in a different class from her great neighbor on the continent; and the peculiar political and economic relationship which the Spanish-American war brought into being between the Philippine Islands and the United States differentiates that archipelago from both the other Oriental countries mentioned.

New Zealand and Australia, in spite of local contrasts, are sufficiently similar through their possession of an almost exclusively Anglo-Saxon population and through their special economic relationship to England, to make it possible to treat them as a unit.

It is proposed to avoid a confusing multiplication of 
statistics by grouping the countries which it is necessary to consider in the manner just indicated. Instead of examining the score or more countries separately, the number is reduced to seven countries and groups of countries, as follows:-1, Mexico; 2, Central America and Colombia; 3, West coast of South America (excepting Colombia and including Bolivia); 4, China; 5, Japan; 6, British Australasia; 7 , the Philippine Islands.

In the five years 1897-1901 the United States and Europe exported to the above seven groups of countries merchandise to the total value of $\$ 423,000,000^{1}$ per annum. In the five years 1907-I9I I, this average had risen to $\$ 699,000, \infty 00$ per annum, an increase of 65 per cent.

In return the United States and Europe took from the Pacific countries, goods valued at $\$ 541, \infty 00,000$ per annum for the years $1897-1901$ and $\$ 972, \infty 00, \infty 00$ per annum for 1907-1911, an increase of 80 per cent.

The shares of the individual countries of Europe and the United States in these exports and imports are indicated in the following table:

1 These figures for the United States include exports from the Pacific as well as the Atlantic slope of the country, but those from the Pacific slope are insignificant. 
TRADE WITH MEXICO, CENTRAL AMERICA AND COLOMBIA, WEST COAST OF SOUTH AMERICA, CHINA, JAPAN, PHILIPPINE ISLANDS, AND BRITISH AUSTRALASIA 1

Annual averages in millions of dollars

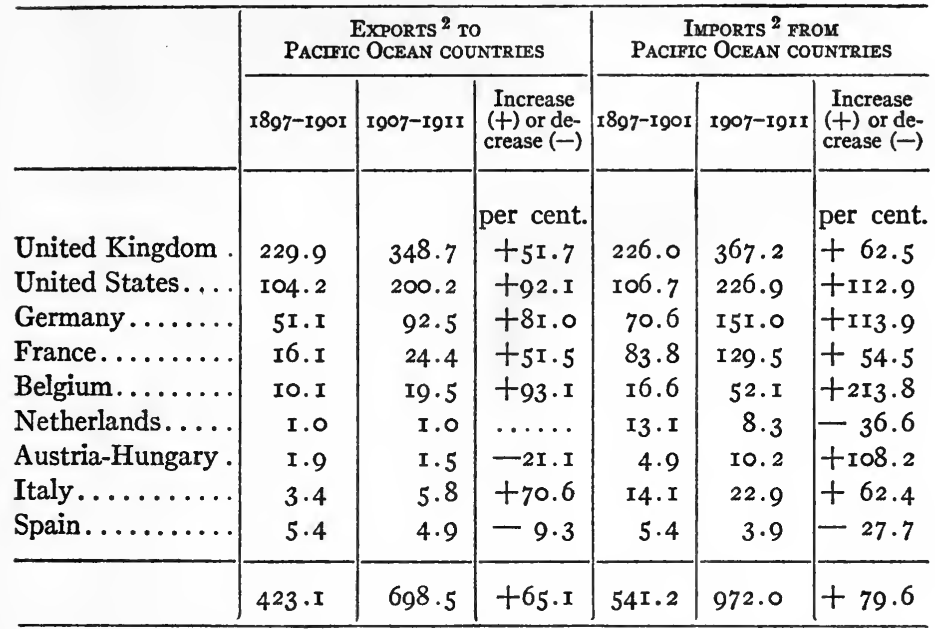

${ }^{1}$ Several other lesser countries of Europe also take some small part in the trade, but the amount is so insignificant that their omission does not alter the conclusions to be drawn from the table.

2 Exclusive of precious metals.

It will be seen at a glance that the United States, the United Kingdom, and Germany really control the trade. Together they supply nearly 92 per cent. of the exports and take 77 per cent. of the imports. If we add France to these three we account for 95 per cent. of the exports and 90 per cent. of the imports. Only in regard to the trade of particular countries, cases which will be mentioned in the proper place, do any of the other countries of Europe compete to a sufficient extent to deserve consideration in the problem of the canal. 
It will be noticed also that among these three or four chief competitors the United States has considerably more than held its own compared with England or France and has just about maintained its position relative to Germany. In 1897-1901 the United Kingdom furnished 54.3 per cent. of the exports to the Pacific countries in question; the United States, 24.6 per cent.; Germany, I 2.8 per cent.; and France, 3.8 per cent. In I $907-$ I9I I the share of the United Kingdom had dropped to 49.9 per cent., and of France to 3.5. Germany's share had risen a little to 13.2 per cent., while that of the United States had gone up to 28.7.

Of the purchases from the Pacific countries, the United States, in 1897-r9or, took only 19.7 per cent., but in 1907I9II, our share had risen to 23.3 per cent. Germany's share meanwhile increased in almost exactly the same proportions, from 13.0 per cent. to 15.6 per cent. Both England and France show a decline, the former from 41.8 per cent. to 37.8 ; and the latter, from 15.5 to 13.3 . The merchants of the United States have no reason to be discouraged with such a showing. England's share of the exports which in the first period were two and one-fifth times as large as ours, are now only about 70 per cent. larger and a very similar change has taken place in regard to imports.

The United States has not, however, been equally successful in all these markets of the Pacific. We shall get a clearer view of the actual conditions if we examine the dealings with the separate countries and groups. We may take the exports and imports separately. 


\section{EXPORTS}

\section{A. Central America and Colombia}

EXPORTS TO CENTRAL AMERICA AND COLOMBIA FROM THE UNITED STATES AND CHIEF EUROPEAN COUNTRIES

Values in millions of dollars

\begin{tabular}{|c|c|c|c|c|c|c|}
\hline \multirow[b]{2}{*}{ Country . } & \multicolumn{2}{|c|}{$1897-1901$} & \multicolumn{2}{|c|}{$1902-1906$} & \multicolumn{2}{|c|}{$1907-1911$} \\
\hline & $\begin{array}{c}\text { Average } \\
\text { export } \\
\text { per } \\
\text { annum }\end{array}$ & $\begin{array}{c}\text { Percent- } \\
\text { age of } \\
\text { total }\end{array}$ & $\begin{array}{l}\text { Average } \\
\text { export } \\
\text { per } \\
\text { annum }\end{array}$ & $\begin{array}{l}\text { Percent- } \\
\text { age of } \\
\text { total }\end{array}$ & $\begin{array}{l}\text { Average } \\
\text { export } \\
\text { per } \\
\text { annum }\end{array}$ & $\begin{array}{l}\text { Percent- } \\
\text { age of } \\
\text { total }\end{array}$ \\
\hline United States.... . & 8.96 & 38.4 & II. I8 & 40.2 & $\mathrm{I} 3.62$ & 40.9 \\
\hline United Kingdom... & $7 \cdot 56$ & 32.4 & 8.12 & 29.2 & 10.40 & $3 I \cdot 2$ \\
\hline Germany....... & 2.52 & 10.8 & $3 \cdot 48$ & I 2.5 & $4.13^{2}$ & 12.4 \\
\hline France...... & 2.86 & $\mathrm{x} 2 \cdot 3$ & 3.00 & I0. 8 & $3.20^{2}$ & 9.6 \\
\hline Italy. . . & 0.98 & 4.2 & I. I4 & $4 \cdot I$ & $1 . \infty 0^{1}$ & 3.0 \\
\hline Spain..... . & 0.32 & I. 3 & 0.62 & 2.2 & $0.57^{2}$ & I.7 \\
\hline Belgium..... & 0.13 & 0.6 & 0.26 & I.O & $0.38^{2}$ & I. 2 \\
\hline Total. . & $23 \cdot 33$ & & 27.80 & & $33 \cdot 30$ & \\
\hline
\end{tabular}

1 Partly estimated.

24 years, r907-rgro, only.

It will be seen at a glance that the United States is well in the lead in this trade. The exports of Italy, Spain, and Belgium are inconsiderable and the only real rivals of the United States are England, Germany, and France. Of these three, England and France have declined somewhat in their percentage of the total sales while Germany shows some increase from the first to the second period but remained practically stationary in the third. The United States is the only country which shows increase in both the second and third periods, though the rise in the third is very slight. 
The explanation of our preponderance in these markets is to be found, in great part, in the advantage of proximity. The ports of Central America and Colombia are some 2,500 miles nearer to New York than to the great European ports, and over 3,000 miles nearer to New Orleans. The opening of the canal will but accentuate the advantage already existing by making accessible the Pacific as well as the Atlantic ports of these Latin-American countries. Commercial activity will probably be stimulated considerably by the general opening of new opportunities but the canal will give the United States no advantage of distance which we do not already possess.

\section{B. Mexico}

The figures of exports to Mexico show the following:

EXPORTS TO MEXICO FROM THE UNITED STATES AND CHIEF EUROPEAN COUNTRIES

Values in millions of dollars

\begin{tabular}{|c|c|c|c|c|c|c|}
\hline \multirow[b]{2}{*}{ CoUntay } & \multicolumn{2}{|c|}{$1807-1001$} & \multicolumn{2}{|c|}{$1002-1006$} & \multicolumn{2}{|c|}{$1007-1918$} \\
\hline & $\begin{array}{l}\text { Averase } \\
\text { export } \\
\text { per } \\
\text { annum }\end{array}$ & $\begin{array}{l}\text { Percent- } \\
\text { age of } \\
\text { total }\end{array}$ & $\begin{array}{c}\text { Average } \\
\text { export } \\
\text { per } \\
\text { annum }\end{array}$ & $\begin{array}{l}\text { Percent- } \\
\text { ase of } \\
\text { total }\end{array}$ & $\begin{array}{l}\text { Average } \\
\text { export } \\
\text { pet } \\
\text { annum }\end{array}$ & $\begin{array}{l}\text { Percent- } \\
\text { ase of } \\
\text { colal }\end{array}$ \\
\hline United States. . . . . . . . & 27.40 & 56.0 & $45 \cdot 46$ & 59.0 & 57.40 & 62.1 \\
\hline United Kingdom. . & 8.66 & 17.7 & 9.82 & 12.8 & 11.58 & 12.5 \\
\hline Germany....... & $5 \cdot 44$ & II. I & 9.94 & 12.9 & $10.75^{2}$ & 11.6 \\
\hline France......... & $4 \cdot 5^{8}$ & 9.4 & 5.98 & 7.8 & $7 \cdot 58^{2}$ & 8.2 \\
\hline Spain... . & $1 \cdot 34$ & 2.8 & 2.62 & 3.4 & $2.48^{2}$ & 2.7 \\
\hline Belgium. . & $1 \cdot 32$ & 2.7 & 2.06 & 2.7 & $1.63^{2}$ & 1.8 \\
\hline Italy....... & 0.16 & 0.3 & 1.12 & $\mathrm{I} .4$ & $1 . \infty^{1}$ & 1.1 \\
\hline Total. & 48.90 & & $77 . \infty$ & & 92.42 & \\
\hline
\end{tabular}

1 Partly estimated.

24 years, 1907-1910, only. 
As might be expected from the peculiar geographical relations between the United States and Mexico, we hold more of this trade than all of our competitors combined; indeed, our share is rapidly approaching two-thirds of the total. The bulk of the population of our southern neighbor, and most of her economic activities, are to be found in the high plateau region. From the coast, either on the Atlantic or the Pacific side, to this plateau, the approaches are diffcult and the gradients high. Transportation from the few good ports which do exist, is therefore costly; and routes of travel and trade naturally follow the lines of least resistance which carry them, by easier and cheaper routes, over moderate slopes, across the northern borders into connection with the great traffic lines of the United States. We are further helped by the great investments of American capital in Mexican enterprises in which respect we also probably far exceed any other nation.

England and Germany hold about equal shares of the trade at present, but both show a tendency to decline, especially the former, whose percentage of the total has dropped from 17.7 per cent. to 12.5 per cent. between the first and the third period. France, Spain, Belgium, and Italy, which together contribute about one-seventh of the total export, remain approximately stationary. The gains of the United States, therefore, seem to be made chiefly at the expense of England, a fact which is probably accounted for in part by the substitution in recent years of American for English capital in Mexican investments.

American control of the market is likely to be strength- 
ened rather than weakened as time goes by, but, as in the case of Central America and Colombia, it does not seem probable that the opening of the Panama Canal will exert any direct influence in this direction; for even with the new routes in operation we will possess no advantages here which are not already ours, save that which will come indirectly through the passing of more frequent freight carriers from Atlantic and Gulf ports of the United States along the Pacific coast of Mexico, with a consequent improvement of shipping facilities to ports on that coast. As the same, however, will be true, though possibly to a somewhat less extent, in regard to vessels coming from European ports, it is not at all certain that the United States will gain any relative advantage in consequence.

C. West Coast of South America: Bolivia, Chile, Ecuador, and Peru

It is frequently stated, in somewhat general terms, that the United States is losing ground in the trade with these countries, and the figures, therefore, are of somewhat peculiar interest. They are:- 
EXPORTS FROM THE UNITED STATES AND CHIEF EUROPEAN COUNTRIES TO THE WEST COAST OF SOUTH AMERICA

Values in millions of dollars

\begin{tabular}{|c|c|c|c|c|c|c|}
\hline \multirow[b]{2}{*}{ CoUntry } & \multicolumn{2}{|c|}{$1897-I 901$} & \multicolumn{2}{|c|}{$1902-1906$} & \multicolumn{2}{|c|}{ I907-I9II } \\
\hline & $\begin{array}{c}\text { Average } \\
\text { export } \\
\text { per } \\
\text { annum }\end{array}$ & $\begin{array}{c}\text { Percent- } \\
\text { age of } \\
\text { total }\end{array}$ & $\begin{array}{c}\text { Average } \\
\text { export per } \\
\text { annum }\end{array}$ & $\begin{array}{l}\text { Percent- } \\
\text { age of } \\
\text { total }\end{array}$ & $\begin{array}{l}\text { Average } \\
\text { export per } \\
\text { annum }\end{array}$ & $\begin{array}{c}\text { Percent- } \\
\text { age of } \\
\text { total }\end{array}$ \\
\hline United States. . . . . & 6.03 & $14 \cdot 5$ & 10.59 & $\mathrm{r} 6.6$ & $\mathrm{I7} .4 \mathrm{I}$ & $19 \cdot 3$ \\
\hline United Kingdom........ & 18. I8 & 44.0 & 26.30 & $4 I \cdot 3$ & 36.68 & 40.6 \\
\hline Germany...... & 10.64 & $25 \cdot 7$ & I6. 24 & 25.6 & $21.77^{2}$ & $24 . I$ \\
\hline France.... & 3.66 & 8.9 & 4.68 & $7 \cdot 4$ & $7 \cdot 43^{2}$ & 8.2 \\
\hline Belgium. . & I.38 & $3 \cdot 3$ & $3 \cdot 78$ & $5 \cdot 9$ & $4.04^{2}$ & $4 \cdot 5$ \\
\hline Italy......... & I. 48 & 3.6 & 2.04 & 3.2 & $3.00^{1}$ & $3 \cdot 3$ \\
\hline Total. & $4 \mathrm{I} \cdot 37$ & & 63.63 & & 90.33 & \\
\hline
\end{tabular}

1 Partly estimated.

24 years, 1907-r9io, only.

In respect to the bulk of this trade, the United States has held no great advantage in the matter of distance. Some goods, it is true, have gone to the West Coast ports via Panama if the saving in time was sufficient to overcome the disadvantage of transshipment across the Isthmus. In Ecuador and the extreme northern part of Peru, the proportion of freight preferring this route has been fairly large. It has decreased rapidly towards the south in Peru and has been practically nil in Chile; and as the imports of Ecuador and northern Peru form but an insignificant part of the totals stated above, the relative proximity of Panama to New Orleans or New York has played but a small part in determining the sources of supply of these West Coast countries as a whole. Most of the freight from the United States, as from Europe, has chosen the route through the Straits of 
Magellan. The distance to these West Coast ports via this route is from New York only three hundred sixty-seven miles less, while from New Orleans, it is forty-nine miles more than from Liverpool.

Examining the table given above, it will be noticed that although England and Germany both hold a larger proportion of the trade than the United States, yet the share of each of them is declining (from 44.0 per cent. to 40.6 per cent. for the former, and from 25.7 per cent. to 24.1 per cent. for the latter) while the United States has seen her share of the business grow from 14.5 per cent. to 19.3 per cent. France, Belgium, and Italy together hold less than one-sixth of the trade, and there has been no increase in percentage except in the case of Belgium, which shows a slight gain.

The figures for the separate countries of this group do not reveal any materially different tendencies from those revealed by the above table for the four countries combined. Chile's imports from the United States and Europe, which averaged $\$ 27,420,000$ per annum for the period 1897-roor, have risen to $\$ 6_{3}, 165, \infty 00$. England's share has decreased from 44.9 per cent. to 42.9 per cent. and Germany's from 25.9 per cent. to 24.7 per cent. In the same time the United States has increased her proportion from II.5 per cent. to I4.3 per cent. In Peru the imports have similarly increased from a total of $\$ 9,3 \infty 0, \infty 00$ to $\$ 18,995, \infty \infty$. The share coming from England has been reduced from 44.7 per cent. to 38.6 per cent.; and Germany has suffered a falling off from 21.3 per cent. to 7 .5 per cent. The United States, on the other 
hand, has raised her percentage from I8.3 per cent. to 29.I per cent., now occupying second place among the competitors. Ecuador's imports are very small, but they reveal the same tendencies. Of a total import of $\$ 3,920,000$ from the United States and Europe for the five years, r897-1901, the United Kingdom supplied 43.9 per cent.; the United States, 29.I per cent.; and Germany, 22.4 per cent. For I907-I9I I the total had grown to $\$ 5,605,000$ per annum; but England's share of this had fallen to 39.6 per cent., and Germany's, to 2r.o per cent.; while the share of the United States had risen to 35.0 per cent., being now but slightly behind England's and approaching a figure which is double that of Germany.

The opening of the Panama Canal will effect a profound change in our relations with these west coast countries. With it we shall have an all-sea route which will be from 2,500 to 3,000 miles shorter than routes from Europe. Even with high canal tolls, the saving in freights and the expediting of commercial transactions will be so great that practically all of our goods going to these countries will choose the Panama, and abandon the Magellan route. The volume of trade will unquestionably increase rapidly and the growth of our share of it will be even more marked. It cannot be more than a few years before we shall have passed both England and Germany.

\section{China}

In China during the past twenty years a series of events of world-wide importance have occurred to check what 
might be called the normal development of trade relations. The Chino-Japanese War, the Boxer Rebellion, the RussoJapanese War, and more recently, the Revolution, have all left their mark on the statistics of foreign trade in such a way as to make it more difficult than usual to draw conclusions from the figures. A resumé of these figures appears in the following table:

EXPORTS TO CHINA (INCLUDING HONGKONG) FROM THE UNITED STATES AND CHIEF EUROPEAN COUNTRIES

Values in millions of dollars

\begin{tabular}{|c|c|c|c|c|c|c|}
\hline \multirow[b]{2}{*}{ Countrx } & \multicolumn{2}{|c|}{$1897-8908$} & \multicolumn{2}{|c|}{$1902-1006$} & \multicolumn{2}{|c|}{$1907-8918$} \\
\hline & $\begin{array}{c}\text { Average } \\
\text { export } \\
\text { per } \\
\text { annum }\end{array}$ & $\begin{array}{l}\text { Per cent- } \\
\text { age of } \\
\text { total }\end{array}$ & $\begin{array}{c}\text { Average } \\
\text { export } \\
\text { per } \\
\text { ansum }\end{array}$ & $\begin{array}{l}\text { Percent- } \\
\text { afe of } \\
\text { total }\end{array}$ & $\begin{array}{c}\text { Average } \\
\text { export } \\
\text { per } \\
\text { anaum }\end{array}$ & $\begin{array}{l}\text { Percent- } \\
\text { age of } \\
\text { cotal }\end{array}$ \\
\hline United States. . . . . . . . & 19.62 & $24 \cdot 3$ & 39.60 & 27.2 & 30.30 & 22.5 \\
\hline United Kingdom. . . . . . . & 40.70 & 50.3 & 62.30 & 42.9 & 65.26 & 48.4 \\
\hline Germany ............. & $11 . \infty$ & 13.6 & 16.68 & 11.5 & $16.15^{2}$ & 12.0 \\
\hline Russia......... & $3 \cdot 78$ & $4 \cdot 7$ & 14.82 & 10.2 & $12.27^{1}$ & 9.1 \\
\hline Belgium... & $3 \cdot 30$ & $4 \cdot 1$ & $7 \cdot 22$ & $4 \cdot 9$ & $6.15^{1}$ & $4 \cdot 5$ \\
\hline France.... & 1.52 & 1.9 & $2.5^{8}$ & 1.8 & $2.90^{1}$ & 2.2 \\
\hline Holland.... & 0.53 & 0.6 & I. 16 & 0.8 & I. $10^{1}$ & 0.8 \\
\hline Aust.-Hungary. . . & 0.40 & 0.5 & $1 . \infty$ & 0.7 & 0.66 & 0.5 \\
\hline Total. & 80.85 & & $145 \cdot 3^{6}$ & & $134 \cdot 79$ & \\
\hline
\end{tabular}

14 years, 1907-1910, only.

The Russo-Japanese War, occurring in the second of the five-year periods under consideration (1902-1906) was so disturbing an element in the trade of the Orient that we shall probably get a fairer view of the more permanent lines of development by comparing merely the first and third periods. The war acted as a powerful stimulant to 
Chinese import trade because, in order to escape naval or military dangers, many goods which were intended for use by one or the other belligerent nations, were undoubtedly sent to Chinese ports for transshipment to their final destination, thus accounting for the fact that imports during the second period (I902-1906) were considerably larger than during the third (I907-I9II).

Comparing, then, the first with the third period, it will be noticed that all of the three greatest exporters of fifteen years ago have shown a decline in the latest group of years, in the shares which they held in the market. England has fallen from 50.3 per cent. of the total, to 48.4 per cent.; the United States from 24.3 per cent. to 22.5 per cent.; and Germany, from I3.6 per cent. to 12.0 per cent. Belgium, France, Holland, and Austro-Hungary, on the other hand, have all risen slightly. Together, they held 7.I per cent. of the business in $1897-$ r9or and this had increased to 8.0 per cent. in r907-I9Ir. Probably the most striking item in the table is the sudden rise of Russia into considerable prominence as an exporter. Her $\$ 3,780,000$ worth of sales per annum in I897-I90I, or 4.7 per cent. of the total, jumped to $\$ 14,820,000$ or 10.2 per cent. in 1902-1906, and have remained at $\$ 12,270,000$ or 9.I per cent. for 1907 -I9II. The sudden increase in the second period unquestionably has some important connection with the military necessities of the period, but the maintenance of the trade at a high level since the close of the war must be explained in some other way. It is probably closely connected with Russian activities in Manchuria. 
Concerning the trend of trade development as affecting the three most important competitors, England, Germany, and the United States, the figures under review give but little indication. The three are just about maintaining their relative positions. In this respect they will start on equal terms under the new conditions which will be brought about by the opening of the canal. And the opening of the new route will not change the conditions of the competition in China in any such great degree as is often stated. The distance from Europe, via Panama, to Chinese ports is so much greater than via Suez that it is not probable that any considerable share of the traffic would follow the new highway even if it were toll-free. Even from New York the relative distances are such that vessels bound for Hongkong will probably use the Panama route only if all other conditions are favorable. Hongkong stands very close to the dividing line between the zones of influence of the two canals. With equal tolls the traffic will probably divide itself between the two routes. Any future success which the United States is to achieve in gaining a larger share of the business of Southern China must, therefore, depend chiefly on other factors than any direct advantage we are likely to derive from the opening of the Panama Canal. In Northern China the new route will exert a greater influence but not by any means so important as in the South American States.

\section{E. Japan}

With Japan the situation is different. The canal will be of much greater assistance to us here, and, our present 
position being stronger, we make a better start. The export figures for the fifteen years, I897-I9I I, show the following:

\section{EXPORTS TO JAPAN FROM THE UNITED STATES AND CHIEF EUROPEAN COUNTRIES}

Values in millions of dollars

\begin{tabular}{|c|c|c|c|c|c|c|}
\hline \multirow[b]{2}{*}{ CoUntry } & \multicolumn{2}{|c|}{ r897-rgor } & \multicolumn{2}{|c|}{$1902-1906$} & \multicolumn{2}{|c|}{ I907-I9rI } \\
\hline & $\begin{array}{c}\text { Average } \\
\text { export } \\
\text { per } \\
\text { annum }\end{array}$ & $\begin{array}{c}\text { Percent- } \\
\text { age of } \\
\text { total }\end{array}$ & $\begin{array}{c}\text { Average } \\
\text { export } \\
\text { per } \\
\text { annum }\end{array}$ & $\begin{array}{c}\text { Percent- } \\
\text { age of } \\
\text { total }\end{array}$ & $\begin{array}{c}\text { Average } \\
\text { export } \\
\text { per } \\
\text { annum }\end{array}$ & $\begin{array}{l}\text { Percent- } \\
\text { age of } \\
\text { total }\end{array}$ \\
\hline United States......... & I9.64 & 27.0 & $31 \cdot x 6$ & 35.2 & $3^{2} .92$ & $29 \cdot 3$ \\
\hline United Kingdom....... & $35 \cdot 5^{8}$ & 48.9 & 36.12 & 40.7 & 51.02 & $45 \cdot 3$ \\
\hline Germany.......... & II. 36 & 15.6 & I5.26 & 17.2 & $21.83^{1}$ & $\mathrm{I} 9.4$ \\
\hline Belgium. & 2.28 & $3 . I$ & 3.72 & 4.2 & $4.03^{1}$ & 3.6 \\
\hline France... & 2.16 & 3.0 & I. 02 & I. 2 & I. $68^{1}$ & I. 5 \\
\hline Austro-Hungary. . . & I. 53 & $2 . I$ & 0.98 & I.I & $0.90^{1}$ & 0.8 \\
\hline Holland........ & 0.25 & 0.3 & 0.38 & 0.4 & $0.15^{1}$ & 0.1 \\
\hline Total. & 72.80 & & 88.64 & & $\operatorname{Ir2.53}$ & \\
\hline
\end{tabular}

${ }^{1} 4$ years, r9o7-r9ro, only.

In this market as in the others which we have considered, only the United States, the United Kingdom, and Germany play any considerable part. Together they control 94 per cent. of the trade. Belgium, France, Austria-Hungary, and Holland hold only the remaining 6 per cent. and their shares are declining, except in the case of Belgium, which shows a slight rise between the first and third periods, from 3.I per cent. to 3.6 per cent. The real competitors of the United States are, therefore, only England and Germany.

As in the case of China, the trend of normal development was disturbed during the second period, I902-I906, be- 
cause of the Russo-Japanese War. In this period American sales to Japan were greatly stimulated. Our geographical position is such that our commerce could not be very carefully scrutinized for infractions of the laws of neutrality. With England and Germany, however, especially the former, there was far less opportunity for evasion. Probably nearly all of their questionable exports to Japan during this period went first to China, and explain the enormous apparent growth of their exports to that country-from $\$ 51,700,000$ per annum in $1897-1901$ to $\$ 78,980,000$ in 1902-1906, an increase of 53 per cent. Their exports to Japan in the same time increased only $\$ 4,400,000$ or 9 per cent.

In the case of the United States, both the direct and indirect methods of getting goods to Japan were used, for exports to Japan increased 59 per cent. and those to China I02 per cent. between 1897-1901 and 1902-1906. Thus the normal development of the Japanese market, like the Chinese, can best be studied by disregarding the middle period, and comparing only the first and third.

England, the United States, and Germany all show a growth in absolute value of exports, but only the United States and Germany, in percentage of the total trade. In other words, England holds a smaller share of the business for 1907-1911 than in 1897-1901. What England, with France, Austria-Hungary, and Holland, has lost the United States and Germany have gained. The United States has increased from $\$ 19,640,000$ per annum to $\$ 32,920,000$ or 68 per cent., but Germany has done even better, rising from $\$ 11,360,000$ to $\$ 21,830,000$ or 92 per 
cent. Thus, although Germany still occupies third place in the competition, she has been meeting with considerably greater success than the United States.

The opening of the Panama Canal will, however, materially alter the conditions of the competition. It will bring Liverpool and Hamburg no nearer to Yokohama, for the Suez route, as we have already seen, will, in the main, continue to be used. New York and New Orleans, on the contrary, will find themselves enabled to use a route which in the case of the former city is 3,768 miles, and in the case of the latter, 5,705 miles shorter than the one now followed. New York, instead of being I,888 miles farther from Japan, by sea route, than Liverpool, will find herself $\mathrm{I}, 880$ miles nearer. Compared with German ports, New York's advantage will be even greater. The choice of routes will not, of course, depend solely upon distance saved. Other factors, which were examined in an earlier chapter, such as distances between coaling stations, cost of fuel, availability of way freights, relative insurance rates, etc., will also play a part, but an advantage in distance of nearly 3,800 miles would be difficult to overcome even if other elements were all adverse. It is altogether probable that the opening of the new route will be followed by a stimulation of our Japanese trade which will soon put us in close rivalry with England for the first place.

\section{F. Australasia}

Of the seven groups of countries which we have under consideration Australasia is the most important purchaser 
of American and European goods, the total imports from the United States, England, Germany, France, Belgium, and Italy (the only important contributors) being over $\$ 225,000,000$ per annum. This exceeds Chinese trade by $\$ 90, \infty 00,000$ and Japanese by $\$ 112,500,000$, and is not much less than the two latter combined. It is greater by $\$ 9,000,000$ than the combined trade of Mexico, Central America, and the West Coast of South America. The development of trade is shown in the following figures:

EXPORTS TO AUSTRALASIA FROM THE UNTTED STATES AND CHIEF EUROPEAN COUNTRIES

Values in millions of dollars

\begin{tabular}{|c|c|c|c|c|c|c|}
\hline \multirow[b]{2}{*}{ Cotntrey } & \multicolumn{2}{|c|}{$1897-1901$} & \multicolumn{2}{|c|}{$1902-1906$} & \multicolumn{2}{|c|}{$1907-19 \times 1$} \\
\hline & $\begin{array}{c}\text { Average } \\
\text { export } \\
\text { per } \\
\text { annum }\end{array}$ & $\begin{array}{l}\text { Percent- } \\
\text { age of } \\
\text { total }\end{array}$ & $\begin{array}{l}\text { Average } \\
\text { export } \\
\text { per } \\
\text { annum }\end{array}$ & $\begin{array}{l}\text { Percent- } \\
\text { age of } \\
\text { total }\end{array}$ & $\begin{array}{c}\text { Average } \\
\text { export } \\
\text { per } \\
\text { anoum }\end{array}$ & $\begin{array}{l}\text { Percent- } \\
\text { ase of } \\
\text { total }\end{array}$ \\
\hline United States..... & 21.94 & $14 \cdot 5$ & 28.66 & $17 \cdot 5$ & 34.84 & $15 \cdot 5$ \\
\hline United Kingdom..... & 115.72 & 76.3 & 119.14 & 72.6 & 168.42 & $74 \cdot 7$ \\
\hline Germany........... & 9.60 & 6.3 & $11 \cdot 30$ & 6.9 & $15.95^{2}$ & $7 \cdot 1$ \\
\hline France...... & $1 \cdot 3^{8}$ & 0.9 & $1 \cdot 34$ & 0.8 & $1.63^{2}$ & 0.7 \\
\hline Belgium. . & 2.16 & 1.4 & 2.54 & I.5 & $3.45^{2}$ & 1.5 \\
\hline Italy....... & 0.84 & 0.6 & 1.10 & 0.7 & I. $20^{1}$ & 0.5 \\
\hline Total. & 151.64 & & 164.08 & & 225.49 & \\
\hline
\end{tabular}

1 Partly estimated.

24 years, 1907-1910, only.

Here again England, the United States, and Germany hold so important a place in the trade that the other countries are negligible. France, Belgium and Italy together, in 1897-1901, controlled but 2.9 per cent. of the business, and in 1907-1911 this had sunk to 2.7 per cent. 
Even Germany's share is so small-6.3 per cent., 6.9 per cent., and 7.I per cent. in the three periods respectivelythat it seems unnecessary to consider her seriously as a competitor even though her percentage has increased slightly. England and the United States hold the center of the stage, with the latter, however, playing a very minor rôle.

Between 1897-1901 and 1902-1906, the United States showed signs of a considerable increase, her share having risen from 14.5 per cent. to 17.5 per cent. of the total sales, while England's declined in about the same ratio, from 76.3 per cent. to 72.6 per cent. It was probably, to a considerable extent, this partial American success which led to the adoption of preferential tariff rates by both Australia and New Zealand in the period I907-r9II; and the reversal of the development in this third period may be considered, roughly, as a measure of the success of the new policy. Our share in the total trade has dropped from 17.5 per cent. to 5.5 per cent., while England's has risen in almost the same proportions, from 72.6 per cent. to 74.7 per cent.

\section{G. The Philippine Islands}

Here, as already pointed out, the United States stands in somewhat the same position of advantage as England does in relation to New Zealand and Australia. In fact our position is stronger, for we have more definite control in the matter of tariff policy. Our occupation and development of the Islands are already having their marked effects. These are clearly shown in the following table: 
EXPORTS TO THE PHILIPPINE ISLANDS FROM THE UNITED STATES AND CHIEF EUROPEAN COUNTRIES

Values in millions of dollars

\begin{tabular}{|c|c|c|c|c|c|c|}
\hline \multirow[b]{2}{*}{ Cookrey } & \multicolumn{2}{|c|}{$1897-1901$} & \multicolumn{2}{|c|}{$1902-1006$} & \multicolumn{2}{|c|}{$1907-1911$} \\
\hline & $\begin{array}{c}\text { Average } \\
\text { exports } \\
\text { per } \\
\text { annum }\end{array}$ & $\begin{array}{c}\text { Percent- } \\
\text { age of } \\
\text { total }\end{array}$ & $\begin{array}{c}\text { Average } \\
\text { exports } \\
\text { per } \\
\text { annum }\end{array}$ & $\begin{array}{l}\text { Percent- } \\
\text { age of } \\
\text { total }\end{array}$ & $\begin{array}{l}\text { Average } \\
\text { exports } \\
\text { per } \\
\text { annum }\end{array}$ & $\begin{array}{c}\text { Percent- } \\
\text { age of } \\
\text { total }\end{array}$ \\
\hline United States.... & I. 44 & 16.1 & 5.16 & $34 \cdot 9$ & $13 \cdot 5^{8}$ & 60.1 \\
\hline United Kingdom. . & 2.96 & 33.1 & 6.38 & 43.1 & $5 \cdot 42$ & 24.0 \\
\hline Germany.............. & 0.98 & $\mathbf{I 1 . 0}$ & 1.30 & 8.8 & $1.60^{1}$ & $7 \cdot 1$ \\
\hline 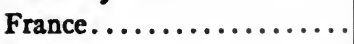 & 0.04 & 0.4 & 0.08 & 0.5 & 0. $10^{1}$ & 0.4 \\
\hline Spain. . . . . . . . & $3 \cdot 5^{2}$ & 39.4 & 1.88 & 12.7 & $1.90^{\prime}$ & 8.4 \\
\hline Total. & 8.94 & & 14.80 & & 22.60 & \\
\hline
\end{tabular}

14 years, 1907-1910, only.

The figures require but little comment. The total trade has increased enormously (153 per cent.), and of the four competitors of any consequence, the United States, England, Germany, and Spain, all except the last mentioned have increased the absolute value of their sales between 1897-1901 and 1907-191r. The preponderance of the United States in the market is, however, becoming daily more marked, and she already holds the lion's share of the business. From 16.I per cent. of the trade in 1897-1901, we jumped to 34.9 per cent. in 1902-1906, and 60.1 per cent. in 1907-1911; England meantime dropping from 33.I per cent. to 24.0 per cent.; Germany, from 11.0 to 7.1 per cent. and Spain from first place with 39.4 per cent. to third place, with 8.4 per cent. Whatever advantages in this market, therefore, may come through the opening of the 
canal will merely accelerate a movement which is already well under way.

The general conclusion which may be drawn from this analysis of American and European exports to the countries which will be affected by the opening of the Panama Canal must be that the position of the United States is a peculiarly strong one. Even without the canal, without a mercantile marine, without extensive direct banking connections, and in spite of our inexperience as an exporter of manufactured goods, we are more than holding our own in most of the groups of countries considered. In Central America, Colombia, Mexico, and the Philippine Islands our advantages are such that the canal will merely hasten and make more complete a condition of commercial supremacy which is already an established fact. In Bolivia, Chile, Ecuador, Peru, Australia, New Zealand, Japan, and, to a certain extent, in China, the canal will do much to remove a handicap of distance under which our Atlantic ports have labored in competition with Liverpool or Hamburg. In the most unfavorable of these markets, in spite of the handicap, we have in the past fifteen years, nearly held our own and in several of them we have considerably strengthened our position. If, now that the canal is opened, our merchants and manufacturers are ready to seize the opportunity presented to them, we may expect to see a great expansion of our trade in the directions indicated. 


\section{IMPORTS}

\section{A. Central America and Colombia}

IMPORTS OF MERCHANDISE INTO THE UNTTED STATES AND CHIEF EUROPEAN COUNTRIES

Annual averages in millions of dollars

\begin{tabular}{|c|c|c|c|c|}
\hline \multirow[b]{2}{*}{ Into } & \multicolumn{2}{|c|}{$8897-3901$} & \multicolumn{2}{|c|}{ 1907-2918 } \\
\hline & Value & $\begin{array}{l}\text { Percentage } \\
\text { of total }\end{array}$ & Value & $\begin{array}{l}\text { Percentage } \\
\text { of total }\end{array}$ \\
\hline United States $1 \ldots \ldots \ldots$ & 13.1 & 40.9 & 18.0 & 43.0 \\
\hline United Kingdom ${ }^{2} \ldots \ldots$ & 6.8 & 21.2 & 7.8 & 18.6 \\
\hline 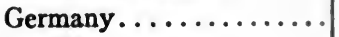 & $8.8^{3}$ & $27 \cdot 3$ & 11.2 & 26.7 \\
\hline France................ & 1.9 & 6.1 & $x .9$ & $4 \cdot 7$ \\
\hline Holland.............. & $\cdots \cdot$ & $\cdots \cdots$ & $\cdots$ & $\cdots$ \\
\hline Austria-Hungary ........ & $\cdots$ & $\cdots$ & 1.5 & $3 \cdot 5$ \\
\hline Belgium . . . . . . . . . . & $\cdots$ & $\cdots$ & 0.5 & $\mathbf{x} .2$ \\
\hline Italy........... & 0.5 & 1.5 & 0.5 & I. 2 \\
\hline 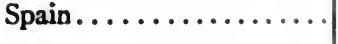 & 1.0 & 3.0 & 0.5 & $\mathbf{x} \cdot \mathbf{x}$ \\
\hline 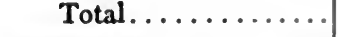 & 32.1 & & 41.9 & \\
\hline
\end{tabular}

${ }^{3} 1898-1901$ and $1907-1910$.

2 Figures include imports from Panama.

${ }^{3}$ Includes precious metals, 0.1 .

The United States holds nearly as much of this trade as her two greatest rivals, England and Germany, together, and, as in the case of exports, is slowly increasing her share. Germany and the United Kingdom both declined, as did all the other countries in Europe except Austria-Hungary and Belgium, while our share increased, from 40.9 per cent. of the total to 43.0 per cent. 


\section{B. Mexico}

IMPORTS OF MERCHANDISE INTO THE UNITED STATES AND CHIEF EUROPEAN COUNTRIES

Annual averages in millions of dollars

\begin{tabular}{|c|c|c|c|c|}
\hline \multirow{2}{*}{ INTo } & \multicolumn{2}{|c|}{ I897-I90I } & \multicolumn{2}{|c|}{ I907-rgII } \\
\hline & Value & $\begin{array}{l}\text { Percentage } \\
\text { of total }\end{array}$ & Value & $\begin{array}{l}\text { Percentage } \\
\text { of total }\end{array}$ \\
\hline United States.......... & 24.9 & 73.9 & 52.6 & $69 \cdot 7$ \\
\hline United Kingdom........ & I.9 & 5.8 & 9.2 & $12 \cdot 3$ \\
\hline Germany ${ }^{1} \ldots \ldots \ldots \ldots$ & 2.9 & 8.7 & $5 \cdot 9$ & $7 \cdot 7$ \\
\hline 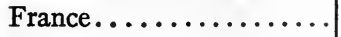 & 2.4 & 7.2 & $4 \cdot 9$ & 6.5 \\
\hline Holland.............. & $\cdots$ & $\cdots$ & $\cdots$ & $\cdots$ \\
\hline Austria-Hungary ........ & $\cdots$ & $\cdots$ & 0.5 & 0.6 \\
\hline Belgium........ & I.O & 2.9 & I.9 & 2.6 \\
\hline Italy .......... & $\cdots$ & $\cdots$ & $\cdots$ & $\cdots$ \\
\hline Spain................ & 0.5 & $\mathbf{I} \cdot 5$ & 0.5 & 0.6 \\
\hline Total.......... & 33.6 & & $75 \cdot 5$ & \\
\hline
\end{tabular}

${ }^{1}$ Includes precious metals, 0.3 and I. I.

In this case the percentage taken by nearly every country in the list declined between the two periods, the exceptions being Austria-Hungary with a negligible share, and England which more than doubled its proportion, having in the second period about one-eighth of the trade. This change is, however, more apparent than real, for during the last period, closer and more frequent direct steamship connections between England and Mexico led to a change in the route of considerable business which had previously gone to England via the United States but which now goes direct. 


\section{West Coast of South America}

IMPORTS OF MERCHANDISE INTO THE UNTTED STATES AND CHIEF EUROPEAN COUNTRIES

Annual averages in millions of dollars

\begin{tabular}{|c|c|c|c|c|}
\hline \multirow{2}{*}{ Inro } & \multicolumn{2}{|c|}{$1897-1901$} & \multicolumn{2}{|c|}{$8007-1918$} \\
\hline & Value & $\begin{array}{l}\text { Percentage } \\
\text { of total }\end{array}$ & Value & $\begin{array}{l}\text { Percentagse } \\
\text { of total }\end{array}$ \\
\hline United States. . . . . . . . & $8 \cdot 3$ & 8.8 & 26.2 & $15 \cdot 5$ \\
\hline United Kingdon. . . . . . . . & 27.8 & 29.4 & 47.6 & 28.2 \\
\hline Germany ${ }^{1} \ldots \ldots \ldots \ldots$ & 24.8 & 26.3 & 47.6 & 28.2 \\
\hline France............ & 14.6 & $15 \cdot 5$ & 20.9 & 12.4 \\
\hline Holland. . . . . & 10.2 & 10.8 & 7.8 & 4.6 \\
\hline Austria-Hungary...$\ldots$. & I.9 & 2.0 & 2.9 & 1.7 \\
\hline Belgium .............. & 5.8 & 6.2 & $13 \cdot 1$ & $7 \cdot 7$ \\
\hline Italy............. & 0.5 & 0.5 & 2.4 & I. 4 \\
\hline 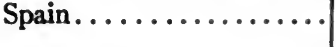 & 0.5 & 0.5 & 0.5 & 0.3 \\
\hline Total............ & $94 \cdot 4$ & & 169.0 & \\
\hline
\end{tabular}

1 Includes precious metals, 3.5 and 0.4 .

There has been a marked increase in the proportion of the exports from these South American countries going to the United States. While the percentage going to England and Germany remained almost stationary, the former showing a slight decline and the latter a slight increase, the share of the United States nearly doubled. France, which in the first period took nearly twice as much as the United States, has now dropped well behind. Holland, Austria-Hungary, Belgium, Italy, and Spain, which together took 20 per cent. of the total, hold now only 15.7 per cent., Belgium and Italy showing some increase and Holland and AustriaHungary a considerable falling off. The percentage going 
to the United States, England, and Germany together has risen from 64.5 to 7 r.9.

\section{China, including Hongkong}

IMPORTS OF MERCHANDISE INTO THE UNITED STATES AND CHIEF EUROPEAN COUNTRIES

Annual averages in millions of dollars

\begin{tabular}{|c|c|c|c|c|}
\hline \multirow{2}{*}{ INTo } & \multicolumn{2}{|c|}{$1897-1901$} & \multicolumn{2}{|c|}{ I907-I9II } \\
\hline & Value & $\begin{array}{l}\text { Percentage } \\
\text { of total }\end{array}$ & Value & $\begin{array}{l}\text { Percentage } \\
\text { of total }\end{array}$ \\
\hline United States. . . . . . . . . & 22.4 & $24 \cdot 9$ & 32.1 & 24.6 \\
\hline United Kingdom . . . . . . . & 16.5 & I8.3 & 20.9 & I6.0 \\
\hline Germany ............ & $5 \cdot 4$ & 6.0 & 19.0 & $14 \cdot 5$ \\
\hline France............... & 32.6 & 36.2 & 38.0 & 29.2 \\
\hline Holland . . . . . . . . . . & 0.5 & 0.6 & 0.5 & 0.4 \\
\hline Austria-Hungary ........ & 1.0 & I.I & 2.4 & I. 8 \\
\hline Belgium . . . . . . . . . . & 1.0 & I.I & $3 \cdot 9$ & 3.0 \\
\hline Italy..... & I0. 2 & II.3 & $13 \cdot I$ & IO.I \\
\hline Spain. . . . . . . . . . . & 0.5 & 0.5 & 0.5 & 0.4 \\
\hline Total $1 \ldots . .$. & $90 . x$ & & 130.4 & \\
\hline
\end{tabular}

1 Russia also takes considerable imports from China, $\$ 22,400,000$ in $1897-$ I90I and $\$ 44,300,000$ in I907-I9II; but as the published figures for the second period include large amounts which do not go to European Russia, but through eastern Russia to Japan, comparisons are vitiated if we include them in the table.

Four countries, the United States, England, Germany, and France, take the bulk of China's exports to the Atlantic basin, 84.3 per cent. in all, France being in the lead through her large purchases of raw silk. Both France and England, however, show considerable relative decline, while the United States has remained practically stationary (in percentage) and Germany has made a remarkable advance, 
chiefly through her increasing purchases of Chinese antimony.

$$
\text { E. Japan }
$$

IMPORTS OF MERCHANDISE INTO THE UNITED STATES AND CHIEF EUROPEAN COUNTRIES

Annual averages in millions of dollars

\begin{tabular}{|c|c|c|c|c|}
\hline \multirow{2}{*}{ INTO } & \multicolumn{2}{|c|}{$8897-1008$} & \multicolumn{2}{|c|}{ 1907-1918 } \\
\hline & Value & $\begin{array}{l}\text { Percentage } \\
\text { of total }\end{array}$ & Value & $\begin{array}{l}\text { Percentape } \\
\text { of total }\end{array}$ \\
\hline United States. & 28.2 & 48.6 & 68.6 & $56 . x$ \\
\hline United Kingdom & $7 \cdot 3$ & 12.6 & 18.0 & 14.7 \\
\hline Germany. . & 3.4 & 5.9 & 7.3 & 6.0 \\
\hline France. & 14.2 & 24.5 & 17.1 & 14.0 \\
\hline Holland. & 1.0 & 1.7 & 0.5 & 0.4 \\
\hline Austria-Hungary & 1.0 & 1.7 & 1.5 & 1.2 \\
\hline Belgium......... & 0.5 & 0.9 & 4.4 & 3.6 \\
\hline Italy $\ldots \ldots \ldots \ldots$ & 2.4 & 4.1 & 4.9 & 4.0 \\
\hline Spain........ & $\ldots$ & $\ldots$ & $\ldots$. & $\ldots$ \\
\hline Total. & 58.0 & & 122.3 & \\
\hline
\end{tabular}

Here again we find the same concentration of trade in the hands of a few Atlantic countries. The United States, England, and France in this case take 84.8 per cent. of the total, Germany, Belgium, and Italy taking nearly all of the remainder. The United States clearly leads as a purchaser, not only holding more than half the total trade but having increased it by 143 per cent. between the two periods. England had increased her much smaller share in about the same proportion, while France has suffered a marked decline. Concerning other countries, the most remarkable case is that of Belgium whose small share has increased 
nearly ninefold. Germany's share has remained relatively unchanged.

$$
\text { F. Australasia }
$$

IMPORTS OF MERCHANDISE INTO THE UNITED STATES AND CHIEF EUROPEAN COUNTRIES

Annual averages in millions of dollars

\begin{tabular}{|c|c|c|c|c|}
\hline \multirow{2}{*}{ InTo } & \multicolumn{2}{|c|}{ I897-I90I } & \multicolumn{2}{|c|}{$1907-I 9 I I$} \\
\hline & Value & $\begin{array}{l}\text { Percentage } \\
\text { of total }\end{array}$ & Value & $\begin{array}{l}\text { Percentage } \\
\text { of total }\end{array}$ \\
\hline United States........ & $4 \cdot 9$ & $2 \cdot 3$ & 17.0 & $4 \cdot 2$ \\
\hline United Kingdom...... & 157.2 & $73 \cdot 4$ & 255.0 & 62.8 \\
\hline Germany............. & 24.8 & II. 6 & $57 \cdot 9$ & 14.2 \\
\hline 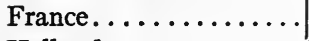 & I6.0 & $7 \cdot 5$ & $4 I \cdot 3$ & IO. 2 \\
\hline Holland............ & $\mathbf{I} .0$ & 0.5 & 2.9 & 0.7 \\
\hline Austria-Hungary ...... & $\mathbf{r . 0}$ & 0.5 & $\mathrm{I} \cdot 5$ & 0.4 \\
\hline Belgium............ & 8.3 & 3.8 & 27.8 & 6.9 \\
\hline Italy..... & 0.5 & 0.2 & $x .9$ & 0.5 \\
\hline Spain............... & 0.5 & 0.2 & 0.5 & 0.1 \\
\hline Total........ & $2 \mathrm{r} 4 \cdot 2$ & & 405.8 & \\
\hline
\end{tabular}

The chief products of Australasia, provisions and foodstuffs, are of course not extensively purchased by the United States, our percentage of the trade consequently being very small. Almost five-eighths of the exports to the Atlantic basin go to England; Germany, France, and Belgium following in the order named, and taking together almost one-third of the total. A noteworthy feature is the relative decline of England between the two periods: in 1897-rgor England took more than three times as much of the trade as Germany, France, and Belgium combined, and in 1907-I9I I her share was only just double theirs. 


\section{G. The Philippine Islands}

IMPORTS OF MERCHANDISE INTO THE UNITED STATES AND CHIEF EUROPEAN COUNTRIES

Anmual averages in millions of dollars

\begin{tabular}{|c|c|c|c|c|}
\hline \multirow[b]{2}{*}{ Inro } & \multicolumn{2}{|c|}{$1897-1908$} & \multicolumn{2}{|c|}{$1907-1911$} \\
\hline & Value & $\begin{array}{l}\text { Percentage } \\
\text { of total }\end{array}$ & Value & $\begin{array}{l}\text { Percentape } \\
\text { of tota }\end{array}$ \\
\hline United States.......... & $4 \cdot 9$ & 27.0 & 12.2 & 39.7 \\
\hline United Kingdom. . . . . . . & 8.3 & $45 \cdot 9$ & 8.3 & 27.0 \\
\hline Germany.............. & 0.5 & 2.7 & 1.0 & 3.2 \\
\hline France................ & I.9 & 10.9 & 5.4 & $17 \cdot 4$ \\
\hline Holland. . . . . . . . . & $\cdots \cdot$ & $\cdots$ & $\cdots \cdots$ & ... \\
\hline Austria-Hungary ........ & $\cdots$ & $\ldots$ & $\cdots$ & -.. \\
\hline Belgium......... & $\cdots$ & $\cdots$ & 0.5 & 1.6 \\
\hline Italy $\ldots \ldots \ldots \ldots \ldots \ldots$ & $\cdots$ & $\cdots$ & $\cdots$ & $\cdots$ \\
\hline 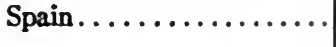 & 2.4 & $13 \cdot 5$ & $3 \cdot 4$ & 11.1 \\
\hline Total............. & 18.0 & & 30.8 & \\
\hline
\end{tabular}

As might be expected, the closer political relations between the Philippine Islands and the United States resulting from the Spanish War, have led to a profound change in the direction of the trade. In 1897-1901 73 per cent. of the purchases were made by England, Spain, France, and Germany, in the order named. Now Spain's share, and England's, have declined, the latter most markedly. Germany and France both show an increase, but they are now far outstripped by the United States. Our imports have increased 149 per cent. between the two periods, and are approaching an amount equal to the imports of all other Atlantic basin countries together.

This analysis of the imports from the Pacific countries 
into the nations bordering the Atlantic leads to conclusions very similar to those derived from an examination of the export figures. There is a strong concentration of the trade in the hands of a very small group of countries. From most of the countries the United States imports less than do her European rivals, for the commodities which many of the Pacific countries have to sell are of the sort produced in abundance in the United States. From Japan, however, with its great production of silk and tea we purchase more than all European countries combined and the same is true in regard to Mexico and Central America whose mineral and tropical vegetable products we can use to advantage. Philippine products are also supplementary to our own and this fact combined with our partial political control, has placed us in the first rank as a market for Philippine exports. Even in the import trade from those countries in which we play a smaller part, our purchases are in general increasing more rapidly than those of Europe. This is true for the entire west coast of South America, and even for Australasia. In China we are more than holding our own with regard to England and France, but Germany seems to be threatening to overtake us. On the whole our position in both the export and import trade is being materially strengthened.

Turning now to the trade of the Pacific slope of the United States and Canada, it will be found impossible to present any such definite figures as those given in the preceding tables, but there are indications that the trend of commercial activity is very similar to that noted above. 
The commerce of Alaska is almost wholly in American hands. In British Columbia the origin of a large part of the imports and the destination of most of the exports is unquestionably in eastern Canada or in the mother country, yet the recent large emigration of Americans across the northwest border into the less settled regions of the Canadian West is undoubtedly causing a relative increase of American commerce there. The imports and exports of the Pacific States of the United States are mainly from and to the more densely populated regions of our Atlantic seaboard. Their amount has been estimated at some $\$ 350,000,000$. Compared with this figure the value of exports and imports to and from Europe is very small $(\$ 36,100,000$ for 1911$)$. Of the exports to Europe, England gets the lion's share, $\$ 18,100, \infty 0$ in rgrr out of a total of $\$ 23,300,000$ or nearly 78 per cent. Germany gets II per cent. and France 7 per cent. In imports from Europe, England also leads, but by a much smaller margin. Of the total imports from the eastern shores of the Atlantic $(\$ 12,800,000$ in 1911) England supplied $\$ 3,700,000$ or 29 per cent., while Germany sent 22 per cent., France 15, and Italy 12. On the whole, then, it is safe to conclude that the eastern United States holds a quasi monopoly of the trade of the Pacific Coast States of our country and of Alaska, with England a poor second and the other European countries utterly unimportant competitors except as regards certain imports from Germany and France. For western Canada the trade is almost wholly divided between England and eastern Canada, on the one hand, and the United States, 
on the other, with the United States holding the smaller but increasing proportion. About 60 per cent. of the European sea-borne trade of the Pacific States of the United States centers in San Francisco and practically Ioo per cent. of the similar trade of British Columbia, in Vancouver.

The above analysis of the trade movements between the Atlantic and the Pacific makes it clear that the position of the United States on the whole is by no means so weak as is sometimes claimed by those who can see no promise for the future of our foreign trade unless or until the handicaps discussed in an earlier chapter under which we labor are removed. A full understanding of our position, however, cannot be reached by a mere examination of the figures of total trade such as have been given. Equally important is the question of the composition of the trade, and it will be necessary, therefore, to carry our inquiry farther and to ask what the trade tendencies are in respect to specific sorts of goods. In doing this, it will promote clearness and avoid the confusion resulting from the presentation of too large a mass of details if we first examine the interchange of commodities grouped together into great classes and then turn our attention to only the more significant items within these classes. In the pages which follow, therefore, exports and imports are first examined by classes and afterwards important details are taken up in separate chapters. 


\section{CHAPTER VI}

CLASSES OF EXPORTS TO THE PACIFIC COUNTRIES

Down to this point attention has been directed chiefly to the statistics of total trade in all commodities. There seems to be a wide-spread opinion, however, that although it may be true that the United States has been making a good showing in the total value of her trade with the Pacific Ocean countries, her success has been due rather to increasing export of such raw and semi-raw materials as cotton, foodstuffs, mineral oil, etc., than to any great expansion of her markets for fully manufactured goods. We have already seen in earlier chapters that the center of gravity, so to speak, of the import trade of the Pacific countries is shifting rapidly toward such manufactured goods. In order, therefore, to determine the real position of the United States in these markets and to appreciate the possibilities of future growth, it will be necessary to determine what success we have been having in trade in these specific commodities. For this purpose it will be convenient to use the classification of exports adopted in an earlier chapter into foodstuffs, clothing and clothing materials, structural and industrial materials, and miscellaneous manufactures.

In order to simplify the problem by avoiding a multiplicity of relatively unimportant details, attention may be confined to those Atlantic countries only which are the 
chief competitors for trade, namely, the United States, England, and Germany, with occasional reference to other countries such as France and Belgium, in those few specific cases in which their competition is active.

I. Foodstuffs:-including such items only as breadstuffs (raw or manufactured), provisions, dairy products, fruits, preserves, etc.

In Central America and Colombia the United States controls the bulk of this trade. The value of exports from I 902 to 1906 averaged $\$ 3$, I I 5, 000 per annum. In I907-r I9 I I the figures were almost unchanged, being $\$ 3,158,000$. Germany sold in the same two periods $\$ 458,000$ and $\$ 455,000$ per annum, respectively; and England, $\$ 32,000$ and $\$ 70,000$. In addition to these items which, strictly speaking, are the only ones which should be included under the caption "foodstuffs" are such luxuries as wines, spirits, beer, tobacco, etc., which the Pacific countries purchase in considerable quantities. Of these articles the United States sold to Central America and Colombia $\$ 285,000$ worth per annum in I902-rgo6 and $\$ 242,000$ worth in I907-r9II, a slight decrease. France, Germany, and England, on the other hand all increased their exports of such goods, together sending $\$ 3 \mathrm{I} 4,000$ worth per annum in 1902-1906, and $\$ 456,000$ worth in I907-I9II. For Central America and Colombia, therefore, in spite of the fact that the bulk of the foodstuffs that are imported come from the United States, it is far from true that our increase in trade in recent years has been due to growing traffic in commodities of this sort. Foodstuffs made up 30 per cent. of our total exports to those 
countries in the earlier period, but have declined to 25 per cent. for the second.

To Mexico, there does appear, it is true, a certain tendency toward greater importance of foodstuffs exports. Here again only England, Germany, and France may be said to compete with us at all, and the total of their export is only about one-sixth as great as ours. All of them show an increase, but none of them approaches the United States in the rapidity of the growth of trade. In 1902-1906, the United States sold Mexico foodstuffs to the value of $\$ 5,472,000$ per annum; in 1907-1911 this business had grown to $\$ 9,173, \infty 00$, an increase of 70 per cent. France, Germany, and England together contributed only $\$ 1,127, \infty 00$ and $\$ 1,528,000$ per annum for the two periods, an increase of only 35 per cent. Nevertheless, it would be incorrect to say that the great development of our export trade to Mexico is due to these increasing sales of foodstuffs, for this class of goods makes up only 16 per cent. of our Mexican export business. It is probable, also, that Mexico's relative increase in foreign purchases of foodstuffs is a temporary phenomenon, due to decreased home production resulting from the political disturbances which have devastated large areas of that country.

On the west coast of South America, as in Central America and Colombia, the growth of American trade in foodstuffs also fails to explain the development of our general exports. In 1902-1906, 15 per cent. of our exports to these countries were of this class of goods; in 1907-191r, only $13 \frac{1}{2}$ per cent. The annual average for 1902-1906 was 
$\$ 1,649,000$; in 1907-r9rr, $\$ 2,389,000$, an increase of 45 per cent.; but in the same time, Germany, France, and England, together, increased their exports from $\$ \mathrm{I}, 399,000$ per annum, to $\$ 3,004,000$ or I I 5 per cent. These figures include wines, liquors, beer, tobacco, etc. Excluding such items, American exports for the two periods rose from $\$ 1,632,000$ per annum, to $\$ 2,362,000$ or 45 per cent., while the three competitors mentioned increased their sales from $\$ 878,000$ to $\$ 1,95^{8,000}$ or 123 per cent.

China ${ }^{1}$ in $1897-1901$ received from the United States foodstuffs (excluding tobacco, etc.) to the value of $\$ 4,742,000$ per annum; and in I907-I9II, to the value of $\$ 6,519,000$. In the earlier period this figure represented 24 per cent. of our total sales to that country; in the later, 23 per cent. England's sales stand next to ours with a total of $\$ 667,000$ per annum in the first period, and $\$ 624,000$ in the second. Germany sold $\$ 206,000$ worth in $1897-1901$, and $\$ 386,000$ in I907-I9Ir. In regard to China, therefore, it does appear to be true that our increasing sale of foodstuffs plays a part in upholding the figures for our total trade.

In the import trade of Japan foodstuffs purchased from Europe and the United States are much less important than in the case of China. The United States furnishes the major part of such goods, sending annually five times as much as England and Germany together. But the $\$ 3,572,000$ worth per annum which we sold in I907-I9II made up only ro per cent. of our total exports to that country, compared with nearly I3 per cent. for 1897-r9or. ${ }^{1}$ For the period between

${ }^{1}$ For China and Japan we get a clearer view of the trend of things by com- 
these two, 1902-1906, probably as a result of the demand for foodstuffs during the Russian war, our exports of this sort rose enormously, reaching an annual value of $\$ 6,389,000$ or over 20 per cent. of our total export. In more normal times like the present, Japan is getting increasing quantities of her growing import of foods not from the Atlantic countries but from nearer lands such as Manchuria, Korea, etc.

Countries such as those which make up the Australasian group naturally import but relatively small quantities of foodstuffs proper. For beer, alcohol, wine, spirits, tobacco, etc., they are obliged to turn to some extent to foreign markets, but in provisions, breadstuffs, and dairy products they not only supply their own needs but have a large excess for export. Certain special grades like prepared breakfast foods, fine hams and bacons, biscuits, etc., and such articles as fine jams, preserves, sauces, etc., they do import, but the total is relatively small. German exports of this sort amounted to $\$ 833,000$ per annum from 1907 to 1911 ; English, to $\$ 4,622, \infty \infty$; and those from the United States, to $\$ 1,643, \infty 00$. The German and English figures both show considerable increase over those of 1902-1906 while the American show a decline of 45 per cent. Australasia's total import of all these commodities from Atlantic countriesall "foodstuffs" including wines, beers, spirits, tobacco, etc.-make up only about 7 per cent. of the total import business and are therefore relatively unimportant.

paring the two periods $1897-1901$ and $1907-1911$ than by using the figures for 1902-1906 and 1907-1911, because of the disturbing influences in 19021906, of the Russo-Japanese war. 
Similar conditions exist in the Philippine Islands. The imports of "foodstuffs" from Europe and the United States represent not over ro per cent. of the business, but such trade as does exist has rapidly become concentrated in American hands since the annexation of the Islands, just as the bulk of the Australasia trade is controlled by England. In I907-I9I I the United States sent to the Philippines nearly ten times as much (in value) of these goods, as Germany and England combined. The figures, however, $\$ 1,124,000$ per annum in I902-I906, and $\$ 1,978,000$ in I907-I9II represent but 22 per cent. and I5 per cent. of our total export to these Islands.

On the whole it is clear, then, that the hold which the United States has been able to get and retain on the Pacific Ocean markets is not the result of any considerable advance in our exports of foodstuffs. Only in Mexico does it appear that our exports of such commodities have grown more rapidly than of other goods, and the growth is probably explained by the abnormally increased demand there resulting from civil disturbances and the fact that the United States is the most accessible source of supply of the foodstuffs and provisions needed. To Australasia, Japan, the west coast of South America, and Philippine Islands, our exports of foods are relatively unimportant and in Central America and Colombia, although such goods make up a large share (25 per cent.) of our exports, yet they show a relative decline, having reached 30 per cent. of the total in the earlier period considered.

II. Clothing and clothing materials:-including textile 
piece goods, readymade clothing, boots and shoes, millinery, fancy goods, etc.

Central America and Colombia import almost wholly from the United States, England, Germany, and France; about $8 \mathrm{I}$ per cent. of the total being made up of cotton piece goods and clothing. The United Kingdom sells 30 per cent. more than her three chief competitors combined. The United States comes second but her share is only about 40 per cent. of that of England and has increased between r902-1906 and 1907-1911 only from $\$ 2,600,000$ per annum to $\$ 2,800,000$ or about 8 per cent. while England's has grown from $\$ 5,53$ I, 000 to $\$ 6,695, \infty 00$ or 2 I per cent. Germany and France together sell considerably less than the United States, each showing a slight increase (ro per cent.) between the two periods.

In Mexico the same four countries are competing, but the predominance of England is by no means so marked, her export of $\$ 4,315,000$ per annum, being only 60 per cent. as large as those of her three competitors together. The United States, France, and Germany, follow in the order named, American sales $(\$ 2,757, \infty 00$ per annum) being 6 per cent. larger than France's and 50 per cent. larger than Germany's. English trade has grown by 1 I per cent. between the two periods 1902-1906 and 1907-1911; German has declined by 3 per cent.; while American has increased 34 per cent. and French $3 \mathrm{r}$ per cent. There is a tendency, therefore, for Germany and England to lose ground to France and the United States, but as our exports of these goods amount to less than 5 per cent. of our total sales to 
Mexico, the change is not important as influencing greatly the total volume of our trade.

On the west coast of South America the United States takes but a very minor part in the clothing trade. France sells annually nearly three times; Germany, nearly seven times; and England about fourteen times as much as we. Our small export, $\$ 1,036,000$ per annum in I907-I9II is almost wholly of cotton goods and clothing and it makes up but 6 per cent. of our total sales to these west coast countries. The business has grown slightly since $1902-1906$, about I $41 / 2$ per cent.; but England's sales have increased in the same time 27 per cent., Germany's 30 per cent. and France's 60 per cent. England's exports are chiefly cottons and woolens; Germany's are about one-half cottons and one-third woolens; and France's about 40 per cent. silks. For all three of these European countries the trade in these goods is a large item in their total sales to the west coast of South America. For England they make up 40 per cent. of the total sales; for Germany, 30 per cent.; for France, 37 per cent.; for the United States only 6 per cent.

China's imports of clothing and clothing materials from the Atlantic countries are a far more important item in her foreign purchases than is the case with most of the Pacific lands. Of the total imports from the United States, England, and Germany, no less than 48 per cent. or $\$ 53,536,000$ consists of this class of goods. Of this amount $\$ 47,03 \mathrm{I}, 000$ or nearly $9 \circ$ per cent. are cottons. England is the chief provider: indeed she may be said to have almost a monop- 
oly of the market, for her export of all goods of this class in r907-rgir averaged $\$ 44,794,000$ per annum, while the United States and Germany together sent only $\$ 8,742, \infty 00$ per annum. In cottons alone the British monopoly is even more complete; her sales being $\$ 40,494, \infty 00$ per annum, while those of the United States and Germany combined were only $\$ 6,537, \infty 00$. The trade is a growing one in spite of Japanese competition, but the United States is losing rather than gaining ground. Between $1897-1901$ and 1907I9I I England's sales increased by $\$ 16,801,000$ per annum, or 60 per cent.; and Germany's by $\$ 754,000$, or 39 per cent. American sales, on the other hand, decreased from $\$ 7,195,000$ to $\$ 6,055,000$ or 16 per cent. American exports are almost wholly cottons and England's are $9 \circ$ per cent. cottons. Germany, on the other hand, sells rather more of woolens than of cottons though her trade in the former is declining. England shows an increase in both cottons and woolens.

The extensive development in Japan, in recent years, of modern textile mills, has caused a decline in the relative importance of Japanese foreign purchases of clothing and clothing materials. In 1907-1911, such goods made up only 16 per cent. of the country's purchases from the United States, Germany, and England. Here as in China, the United Kingdom holds the bulk of the trade, $\$ 13,427,000$ per annum for 1907-191 I. Germany sells about one-fourth of this amount and American sales are insignificant, only $\$$ II 7,000 in 1907-19II. English sales are mostly of cottons, $\$ 7,923,000$ out of the $\$ 13,427, \infty 00$; and German, textiles 
other than cottons (mostly woolens), $\$ 3,308,000$ out of $\$ 3,670,000$. The small export of the United States is almost wholly of cottons.

As might be expected, British Australasia purchases practically the whole of its foreign supplies of textiles and clothing from the mother country. England exported to Australia and New Zealand in I907-rgrr more than twelve times as much of these goods as Germany and the United States combined; and this virtual monopoly seems to be strengthening, for in 1902-1906 the English exports had been only about ten times as much as those of Germany and the United States. As in all other Pacific countries, the largest import of this class is of cottons (about 47 per cent.) though woolens are also of considerable importance (about 29 per cent.). German exports though small show a slight tendency to increase in absolute amount while those of the United States are stationary.

Of all the Pacific countries, the Philippine Islands is the only one in which the United States controls the largest share of the trade in clothing and clothing materials. This position we have reached only in recent years. In 1897r90I England sold nearly forty times as much of these goods as we; and Germany six times as much. Even in 1902-1906, after American occupation, English sales were nearly four times ours, though we had passed Germany slightly. In I907-I9II, however, the United States sent 30 per cent. more than England and eight times as much as Germany. The total value of the trade, however, is small; $\$ 7, \mathrm{I} 37,000$ per annum for I907-I9I I, from England, Germany, and the 
United States together or about 35 per cent. of their total exports to the Philippines.

It is clear from the foregoing analysis of the trade in clothing and clothing materials that these goods do not play an important part in the exports from the United States to the Pacific Ocean countries. Of our total exports to all the countries considered above in the years 1902-1906 ( $\$ 172,000,000$ per annum) I 5.6 per cent. or $\$ 26,800,000$ was of this class of goods: in 1907-1911, the percentage had declined to about nine. The fact is, as stated in a previous chapter, that the importation of clothing and clothing materials into the Pacific countries is a declining business. While the aggregate value continues to grow the ratio to total imports is decreasing. This is undoubtedly due to the fact that nearly every one of the countries in question is developing a domestic manufacture of such goods under the stimulus of protective tariffs, and is filling a larger share of their own demand for cheaper grades of goods. The finer goods continue to be imported but they come from the older textile manufacturing countries such as England and Germany rather than from the United States.

III. Mineral oil, raw cottons, lumber, etc.

Writers who are inclined to pessimism concerning the future possibilities of American export trade in manufactures frequently state that one of the important causes of the growth of our export figures is the increasing sale of such raw materials as cotton and crude oil and such partly manufactured articles as refined oil. In regard to the Pacific countries the statistics do not bear out such a statement. 
To only one of these countries do we sell any considerable quantity of raw cotton; to Japan. Our exports in I897-I901 amounted to $\$ 6,460,000$ per annum, or 33 per cent. of our total sales to that country; and in I907-rgrr, to $\$ 10,900,000$ or 33 per cent. of the total. Thus, although this is a large item in our exports to Japan it does not appear to be increasing in relative importance.

Mineral oil we send in larger or smaller quantities to all of the Pacific countries, our aggregate export to them reaching a value of $\$ 15,524,000$ per annum in $1902-1906$ and $\$ 20,263,000$ in $1907-1911$. In the first period this export made up 9.I per cent. of our grand total export to the same countries; in the second period, ro.4 per cent. There has therefore been a slight increase in relative importance. This is due chiefly to an increased export to China which takes a larger quantity of oil from us than any other Pacific country.

Another large item in our export trade which is sometimes mentioned in explanation of the growing aggregate of our sales to Pacific countries is lumber. Much of this of course goes out from our Pacific Coast States and hence should properly be excluded from the figures for trade between the Atlantic and Pacific basins. Yet even when these Pacific States exports are included our total sales to the Pacific countries are relatively small, $\$ 9,059,000$ per annum in 1902-1906 and \$10,559,000 in 1907-r9II, or only about 5 per cent. of our aggregate sales in each of the two periods. They have not increased in relative importance.

IV. Iron and steel manufactures. 
The great development of the total export trade of the United States with the Pacific countries evidently cannot be explained as being due to an expansion in our sales of any classes of goods thus far examined in the present chapter. Most of the growth is due to increasing sales of sundry manufactured goods among which the most important are iron and steel products. Our total exports to all of the Pacific countries of these manufactures were valued at $\$ 45,943,000$ per annum from 1902 to 1906 , and $\$ 67,969,000$ from 1907 to $191 \mathrm{r}$, an increase of 48 per cent. In the former period they made up 27 per cent. of our total export and in the latter 35 per cent. In the same time England's sales rose from $\$ 60,358, \infty 00$ per annum, to $\$ 89,946, \infty 00$ (an increase of 48 per cent.) and Germany's, from $\$ 20,914,000$ to $\$ 30,569,000$ (or 46 per cent.). So far, therefore, as the total sales to Pacific countries are concerned there has been little change in the relative position of these three chief competitors. In regard to the specific groups of countries, however, important differences are to be noted.

To Central America and Colombia the United States sold in 1902-1906, 50 per cent. more of iron and steel manufactures than England and Germany together. By 1907-I9I I our business had increased so rapidly that our total was just double theirs. England's export is nearly double Germany's and is increasing a little more rapidly than that country's though much less than half as fast as that of the United States.

In Mexico the preponderance of the United States is even more striking as is also the rapidity with which we 
are increasing our hold on the market. Our sales of iron and steel in 1907-I9II were nearly three and one-half times as large as Germany's and England's together, amounting to $\$ 22,000,000$, and had risen over $1902-1906$ by 36 per cent. while England's had risen by only in per cent. and Germany's by only 22 per cent. In absolute amount England's and Germany's exports are about equal $(\$ 3,300,000$ and $\$ 3,500,000$ ).

On the west coast of South America our business is relatively smaller. England in I907-I9II sold, here, iron and steel to the value of $\$ 10,237,000$ per annum; Germany, $\$ 6,630,000$ and the United States, $\$ 6,023,000$. England's sales, however, had grown by only 39 per cent. over 1902r 906 , and Germany's by $5 \circ$ per cent., but those of the United States had risen over 66 per cent. It would appear, therefore, that England is losing ground, her loss being taken up by Germany and the United States, and that as between the last two countries, the United States is gaining ground. Our sales which in 1902-1906 amounted to only 82 per cent. of Germany's, in I907-I9I reached 9r per cent. of hers.

Our exports of iron and steel to China are small. In I907I9II England exported $\$ 6,9$ I 5,000 worth of such goods per annum to China, and Germany, $\$ 5, \mathrm{I} 3 \mathrm{I}, 000$ worth. American exports reached only $\$ 1,743,000$. Yet even here there are encouraging signs of development. American sales increased from 1897-I90I to I907-I9II by nearly 9 I per cent., England's, by $3^{8}$ per cent., and Germany's, by only 2I per cent.

In Japan our position is stronger, our sales being about 
one-half those of England and somewhat more than those of Germany. The business as a whole is much larger than that of China, the value of iron and steel exports to Japan from the three chief competitors being $\$ 36,779,000$ per annum, while to China they reach only $\$ 13,789, \infty 00$. Of this total export to Japan, of $\$ 37, \infty 00, \infty 00$, England furnished in 1907-I9r I 52 per cent., the United States, 25 per cent., and Germany, 23 per cent. In this case, however, Germany's sales are increasing more rapidly than those of either of the two other competitors, having grown between 1897-1901 and 1907-191 I, by 164 per cent. American export increased in the same period ro4 per cent., and British, 95 per cent.

As with most of the other classes of goods which we have been considering, British Australasia is the largest purchaser of iron and steel products among the Pacific countries, the imports from England, Germany, and the United States averaging for the years $1907-1911, \$ 66,824,000$ per annum. Of this amount, as might be expected, by far the larger part-nearly 72 per cent.-comes from England. Germany supplies only 9 per cent.; the United States, a little over 19 per cent. Down to the time of the adoption by Australia and New Zealand, a few years ago, of preferential import duties on British goods, both the United States and Germany showed signs of making some headway against this English monopoly of the market, but now the mother country is strengthening its hold again. Between I902-1906 and I907-I9I I British exports increased by 6r per cent.; American, by 37 per cent.; and German, by 33 per 
cent. No other country holds any important share in the trade.

In the Philippine Islands, the relative positions which England and the United States hold in Australasia are almost reversed. Prior to the annexation of the islands American share in the iron and steel exports had been small; less than half those of England, and only about equal to Germany's. Even after our purchase from Spain, England held for a time her leadership in the market, her exports for 1902-I906 being $\$ 2,659,000$ per annum, against our $\$ 1,058,000$. German trade, however, had declined relatively and in that period amounted to less than one-third of ours. But by 1907-I9II a great change had come. American exports jumped to $\$ 3,653,000$ or over 250 per cent., while England's declined to $\$ 955,000$ or only about one-fourth of ours. Germany increased the absolute amount of her sales somewhat-to $\$ 462,000$-but they are now less than one-eighth of ours.

The above figures of the iron and steel trade fully justify the conclusion that the United States is fairly well holding its position in the competition. In those countries in which the American exporters have had an advantage of proximity to the markets,-Mexico, Central America, and Colombia,- they have almost succeeded in reaching a monopoly of the business and are increasing their lead. In countries farther removed (by the old routes) our position is much weaker, yet in several of them at least, there is shown a tendency towards successful competition. On the west coast of South America, in China, and in Japan, our sales are in- 
creasing more rapidly than those of our chief competitor, England; and in all of these countries, except Japan, more rapidly also than Germany's. In the Philippine Islands as in Mexico and Central America, we are rapidly approaching a position of monopoly. Only in British Australasia are we losing ground, and even there our loss is relatively less than Germany's.

\section{General manufactures.}

One more of the great classes of goods purchased by the Pacific countries remains to be considered in the present chapter-general manufactures. The United States, England, and Germany sold these goods to the Pacific countries to the value of $\$ 114,626,000$ per annum in the period 19021906 and $\$ 146,649,000$ in $1907-1911$. Of this amount for 1907-191 I, England supplied nearly 56 per cent.; the United States, 23 per cent., and Germany, 2 I per cent. The United States therefore occupies second place, having about twofifths as much of the trade as England and leading Germany slightly. But relatively we are losing ground. England's sales have increased between the two periods, 39 per cent.; Germany's, 3I per cent.; ours, only 9 per cent.

In one or two of the separate markets, however, our position has been strengthened, notably on the west coast of South America, and in the Philippine Islands. To the former we sold in 1902-1906 \$1,906,000 worth per annum of these goods and in 1907-1911 \$3,144,000 worth; an increase of 65 per cent. England and Germany also both increased their sales, the former at about the same rate (67 per cent.) but the latter much more slowly (only 27 
per cent.). France also, with a smaller total, made a noteworthy increase between the two periods, of 48 per cent. In the Philippine Islands, the same tendency is to be noticed in regard to this class of general manufactures as in the other classes examined, an increasing concentration of the business in American hands. Between 1902-I906 and I907-I9II exports from the United States increased over fourfold; those of England declined by nearly $5 \circ$ per cent., and Germany's increased by about fifty per cent. We now sell nearly as much of these goods as England and Germany combined.

In Central America and Colombia and in Mexico we continue to hold most of the trade, in the former about as much as England, Germany and France together; and in the latter, considerably more than those three combined. But relatively we have lost ground. In Central America and Colombia our sales have increased only 24 per cent. to England's 52 per cent. Germany and France have remained almost stationary. In Mexico our sales have remained practically unchanged as have also those of Germany and France; but England's, though only one-fifth of ours in absolute amount, have increased by 50 per cent.

Australasian trade is almost a British monopoly, for the purchases from the United Kingdom are four times as large as those from the United States and Germany together and have increased by $4 \mathrm{I}$ per cent., while those from Germany have risen 28 per cent., and from the United States, I2 per cent.

The figures for China and Japan for I902-I906 and I907- 
I9I I show a considerable relative decline in the trade of the United States, but a comparison of $1897-1901$ with 1907I9I I, eliminating the disturbed period of the RussoJapanese war, gives a very different picture of the success of American exporters. Between 1897-1901 and 1907-1911 our sales to China, of general manufactures, increased from $\$ 1,420,000$ to $\$ 3,5$ I3,000 or I47 per cent.; England's grew from $\$ 5,839,000$ to $\$ 6,229, \infty 00$ or 7 per cent.; and Germany's, from $\$ 3,909, \infty 00$ to $\$ 6,016, \infty 00$, or 54 per cent. We have therefore greatly strengthened our position relatively to both England and Germany. To Japan, our exports of general manufactures grew rapidly from $1897-1901$ to 1907-191 I, from $\$ 1,814,000$ per annum, to $\$ 4,062,000$, or I 24 per cent.; while England's declined from $\$ 22,070,000$ to $\$ 15,876,000$ or 28 per cent.; and Germany's rose from $\$ 3,243,000$ to $\$ 9,371,000$, or 189 per cent. Compared with England, therefore, the United States has made a remarkable gain, though we have lost ground relatively to Germany.

A résumé of the figures presented concerning the five great classes of exports examined in the preceding pages, reveals some noteworthy facts. They may be summarized as follows:

I. The chief gain which the United States has made in recent years in the Pacific markets has been in iron and steel goods.

2. In foodstuffs, though the United States is still, and seems likely to remain, the chief provider of such foreign supplies as the Pacific countries require, the business is in general a declining one. 
3. In clothing and clothing materials, England and Germany (and to some extent France) supply the bulk of the demand but the business is declining in relative importance.

4. For such raw and semi-raw materials as lumber, mineral oil, etc., the United States being the largest producer is and is likely to remain, for some time at least, the largest seller to Pacific countries. The United States is also naturally the largest Atlantic seller of raw cotton (mainly to Japan). Increasing supplies from India, the East Indies, and China, are however tending to reduce the proportion purchased from the Atlantic basin, the Pacific being increasingly able to supply its own demand in this respect.

5. The sales by the United States of general manufactures is small, and in several of the countries there is a tendency for American exports to fall behind in the competition, yet on the whole there is enough evidence of increasing business to create at least a possibility that with improved facilities for delivery, etc., our manufacturers may be able to turn the trade in their favor.

6. The popular opinion which one hears so often expressed that Germany is our most active competitor in foreign markets is far from being confirmed by the facts. The following table shows the situation at a glance: 


\begin{tabular}{|c|c|c|}
\hline \multirow{3}{*}{ 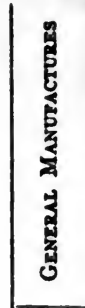 } & 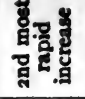 & 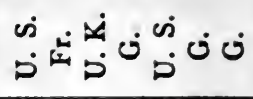 \\
\hline & 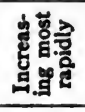 & 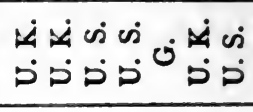 \\
\hline & 莺 & 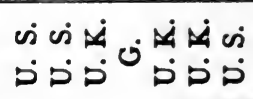 \\
\hline \multirow{3}{*}{ 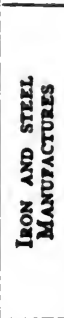 } & 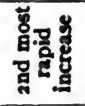 & ن ن ن ن ن ن ن ن ن ن ن ن \\
\hline & 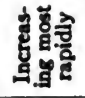 & 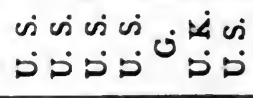 \\
\hline & 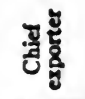 & 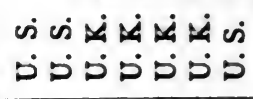 \\
\hline \multirow{3}{*}{ 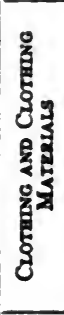 } & 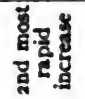 & نّ ن ن ن ن ن ن ن ن ن \\
\hline & 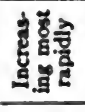 & 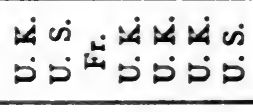 \\
\hline & 竎 & 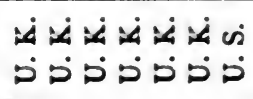 \\
\hline \multirow{3}{*}{ 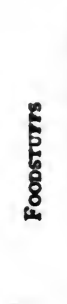 } & 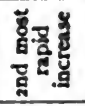 & 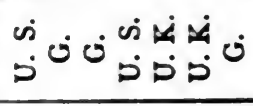 \\
\hline & 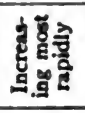 & 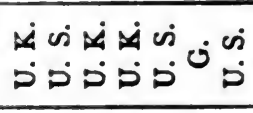 \\
\hline & 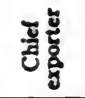 & 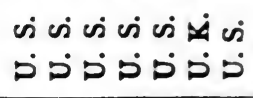 \\
\hline & & 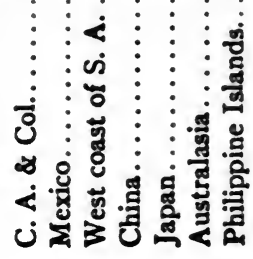 \\
\hline
\end{tabular}


In foodstuffs the United States is the chief exporter to all the Pacific countries except Australasia, but only in Mexico, Japan, and the Philippine Islands is our lead being increased. In Central America and Colombia, on the west coast of South America, and in China, England is making the most rapid advance. Only in Australasia, and on the west coast of South America, is Germany making more rapid progress than the United States. In Mexico and the Philippines, Germany's increase stands next in rapidity to ours.

In clothing and clothing materials England leads in every country except the Philippines. In Central America and Colombia, in China, in Japan, and in Australasia her sales are also increasing more rapidly than those of either the United States or Germany. In Mexico American trade is growing fastest, with France the next most rapid. In the Philippines the United Kingdom stands next to the United States in the rate of growth. Germany is increasing her sales to Central America and Colombia, to China, Japan, and Australasia, more rapidly than we, but not so rapidly as the United Kingdom; and also to the west coast of South America, but not so rapidly as France.

The United States holds the largest share of the trade in iron and steel products with Central America and Colombia, Mexico, and the Philippines, and is increasing the lead. In Central America and Colombia the chief competition, measured in terms of rapidity of increase, comes from England; in Mexico and the Philippines, from Germany. On the west coast of South America, and in China, the 
United States, though far from being in the lead, is increasing more rapidly than any of her competitors. In the former, Germany is the next competitor; and in the latter, England. In none of the countries, with the single exception of Japan, are German sales increasing more rapidly than those of the United States.

In general manufactures the United States is leading exporter to the same countries as in iron and steel-to Central America and Colombia, to Mexico, and to the Philippines. The United Kingdom leads in all the others except China where Germany stands first. English sales are increasing more rapidly than American in Central America and Colombia, in Mexico, and in Australasia; and American more rapidly than English, on the west coast of South America, in China, and in the Philippines. Only in Japan and in Australasia are German sales increasing more rapidly than ours.

Any general statement, therefore, as to which of the European nations is our most formidable competitor in the Pacific markets is misleading. Much depends on the particular class of goods one is considering, or the particular country or group of countries in the Pacific. If any general statement were, however, to be made, it would be far nearer the truth to say that England and not Germany is our chief rival. 


\section{CHAPTER VII}

DETAILS OF EXPORTS TO THE PACIFIC COUNTRIES

THE analysis of exports presented in the preceding chapter has been useful in giving a general idea of the character of the competition for markets in the Pacific countries and the direction in which the various competitors may look for greatest success, yet even such an examination of the trade by general classes would fail to be of great use to a manufacturer or exporter dealing only in specific articles within any class. The individual exporter will wish to know what the prospects may be for the particular commodity which he has to sell.

Unfortunately the difficulties which stand in the way of anything like a complete analysis of trade in specific goods are very great, for the trade statistics of the various commercial nations abound in differences of classification which often prevent statements in figures which are at all comparable with one another. In spite of such limitations, however, an examination in detail, of the exports of the United States and the more important competitors-England and Germany, and in certain cases France-yields results of considerable value. It is the purpose of the present chapter to present a comparison of the trade in all important specific commodities for which comparable 
figures are obtainable. This can best be done by giving first the exports from the United States and then comparing the American business with that of our competitors in each specific line. And we shall get the clearest view by examining each Pacific country or group of countries separately.

\section{Central America and Colombia}

\section{A. Foodstuffs, etc.}

In 1902-1906 the United States exported to Central America and Colombia, foodstuffs ${ }^{1}$ to the value of $\$ 2,775,000$ per annum; in 1907-1911, of $\$ 2,515, \infty 00$. The most important item in the list was breadstuffs, reaching a value of $\$ 1,572,000$ and $\$ 1,436, \infty 00$ per annum for the two periods respectively. By far the largest single item of this sort is wheat flour, $\$ 1,325,000$ and $\$ 1,187,000$ per annum. Next most important are provisions and dairy products, $\$ 650,000$ and $\$ 562, \infty 00$, made up chiefly of lard, lard compound, and tallow, $\$ 401, \infty 00$ and $\$ 342, \infty 00$. Canned goodssalmon and other fish, fruit, vegetables (except canned meats) account for $\$ 53, \infty 00$ and $\$ 47, \infty 00$ for the two periods; and wines, spirits, beer, etc., $\$ 198, \infty 00$ and $\$ 146, \infty 00$. These items, which together make up nearly 90 per cent. of the business, have all shown a decline between the two periods. The only items in the entire list of foodstuffs which had shown an increase are refined sugar and confectionery, but the amounts are so small that the increase is of no significance.

I Including beverages, tobacco, etc. 
English exports of foodstuffs are made up of very different items from the above. They are in the order of their importance: biscuit and cakes, beer and ale, and confectionery and jams. They all are increasing; biscuit and cakes from $\$ 14,000$ per annum in I902-I906 to $\$ 42,000$ per annum in I907-I9II; beer and ale from $\$ 19,000$ to $\$ 30,000$; and confectionery and jams, from $\$ 19,000$ to $\$ 29,000$. The totals are so small however as to be insignificant except as indicating the character of English goods demanded.

Germany like England has but a small export trade in foodstuffs, sending to Central America and Colombia about $\$ 500,000$ worth per annum with a slight tendency to increase. A large item is wines and beer, though confectionery and sugar may also be mentioned.

So far, therefore, as there is any competition with the United States in foodstuffs, it is in the sale of beer, wine, spirits, etc., and jams, preserves, confectionery, etc., of which German and English brands are much better known than the American. French export, $\$ 424,000$ in 1907-I9II, is almost wholly of wines and spirits.

\section{B. Clothing and Clothing Materials}

The total American sales of this class of goods to Central America and Colombia amounted in I907-I9I to $\$ 2,754,000$ per annum, a slight increase over the preceding five years. About 82 per cent. of this total is of cotton goods and $I 7$ per cent. shoe leather and boots and shoes. In silks and woolens our trade is practically nil. The sales of leather and boots and shoes, though small, show a remarkable in- 
crease from $\$ 286,000$ per annum to $\$ 470,000$ or 64 per cent. The trade in boots and shoes alone has remained stationary at $\$ 176,000$ per annum, but that in shoe leather has risen from $\$ 109,000$ to $\$ 295, \infty \infty$, indicating an increase of domestic manufacture of boots and shoes in the countries in question. Our cotton sales are made up almost wholly of three items: colored cotton cloth, $\$ 1,303,000$ per annum; uncolored cotton cloth, \$579,000; and cotton wearing apparel, \$137,00. All three are increasing, the percentages of growth between the two periods being respectively 9, 10, and 49.

English exports to these countries of clothing materials are nearly two and one-half times as large as ours. Like ours they are mainly of cotton goods -88 per cent. of the total. Another 8 per cent. is of woolen goods, the remainder being made up of several small items such as linen goods, hats, and apparel. The sale of woolen goods is practically at a standstill, having increased less than 5 per cent. between the two periods. The cotton trade, however, is increasing, and has risen 23 per cent. between the two periods. The classification in the records is less complete than the American, rendering full comparison impossible. "Piece goods" and "other manufactures" are the only two items, the former being from five to six times greater in value than the latter. Both have increased at about the same rate.

The German sales of clothing to Central America and Colombia are much smaller than those of either England or the United States and are therefore relatively unimportant. Yet one or two points of interest may be noted; the relatively greater importance of woolen goods, which make up 
22 per cent., and of silk goods, which make up ro per cent. of the total. As in the case of England the sale of woolen goods is declining while silks, on the other hand, are showing a rapid increase. The total amount, however, is small; only $\$$ I I9,000 per annum in I907-I9II.

French exports are about equal to those of Germany, \$I,I55,000 per annum, made up almost equally of cottons, woolens, and "vetements." Silk sales, curiously, are smaller than those of Germany, only $\$ 45,000$ per annum, but are increasing rapidly. Cottons and "vetements" remained stationary between the two periods, but French woolens alone among those sent to Central America and Colombia are increasing (20 per cent.). Their amount however is small (\$340,000 per annum) though larger than the German sales.

The United States is so large a manufacturer of readymade clothing that it is of especial interest to compare the figures for trade in these goods. Central America and Colombia purchased clothing from the United States, England, Germany, and France to the value of $\$ 889,000$ per annum from I902 to I906 and $\$ I, I 96,000$ from I907-I9II. Of these totals $\$ 458,000$ worth in I902-I906 and $\$ 684,000$ in I907-I9I I came from the United States; \$292,000 and $\$ 352,000$ from France; and $\$ 139,000$ and $\$ 160,000$ from England and Germany together. The business though small is a growing one and American share in it is increasing. Our sales increased 49 per cent. between the two periods, while France, our nearest competitor, raised her exports by only 20 per cent. English sales are also increasing rapidly, 
32 per cent., but the amount is still very small (less than one-ninth of ours). German sales are stationary.

\section{Iron and Sleel Manufactures}

The chief items of iron and steel goods purchased by such newly developing countries as those of the Pacific basin may be divided into two or three general classes; general structural material, railway material, and machinery. The first would include under the American customs classification such items as bar iron and steel; hoop, band, and scroll iron; iron and steel sheets and plates; structural iron and steel; wire; castings; nails; spikes, etc.; pipes and fittings; hardware, etc. Of these goods we are selling to Central America \$651,000 worth per annum (1907-19ri), an increase of $7 \mathrm{I}$ per cent. over the preceding five years.

Railway material would include steel rails, cars, ${ }^{1}$ car wheels, and locomotives. Our sales for 1902-1906 were valued at $\$ 272,000$ per annum: in 1907-1911 they had increased 49 per cent., to $\$ 405, \infty 0$.

Under machinery and tools may be included agricultural implements and machinery, ${ }^{2}$ automobiles, cycles, carpenters' tools, etc., firearms, electrical machinery, metal working machinery, printing presses, pumps and pumping machinery, laundry machinery, shoe machinery, sewing machines, stationary engines, boilers and parts of engines,

1 Included here under iron and steel, because the chief material (in values) is probably iron and steel.

2 Included in iron and steel because the chief value is probably due to the iron and steel components. 
sugar machinery, woodworking machinery, fire engines, refrigerating machinery, typewriters, cash registers, adding machines, windmills, scales and balances, mining machinery, etc. Our exports of this sort in 1902-1906 were $\$ 705,000$ per annum, but had increased in I907-I9I I to $\$ \mathrm{I}, \mathrm{I} 70,000$, or 66 per cent.

Besides the items which make up these three general classes are numerous smaller ones which are grouped together under the heading of "all other iron and steel and manufactures thereof." Our sales of these in I902-I906 were \$210,000 per annum, and in 1907-I9II, \$29I,000, an increase of 39 per cent.

It is evident, therefore, that the increase in our iron and steel business with Central America and Colombia is due mostly to a growing export of general structural materials and of machinery.

Complete comparisons with European countries are impossible to make because of differences in classification, yet fairly definite conclusions may be drawn from such comparisons as are possible. England, for instance, exports to Central America and Colombia, "machinery," "implements and tools," "cutlery," "arms," etc. (a group of classes which correspond approximately with what we have embraced above under the term machinery and tools) to the value of $\$ 586,000$ per annum (I907-I9II). This is an increase of 54 per cent. over the sales for the preceding five years $(\$ 379,000)$. Germany has a separate class which is stated as "instruments, machinery, and vehicles" which likewise includes roughly the same items as the above. 
The exports for the first period averaged $\$ 128,000$ per annum and for the second, $\$ 188, \infty \infty$, an increase of 47 per cent. French sales of "machinery and tools," "arms," and "vehicles" are small, reaching a total of less than $\$ 1 \infty, \infty 00$ per annum.

Other export items for England, Germany, and France are with a few unimportant exceptions grouped together under a general heading as "iron and steel manufactures." French export is insignificant. England sells a larger quantity than any country except the United States, the average for the years 1907-191 I being $\$ 500,000$ per annum. The business is declining slightly, the export for 19021906 having been $\$ 536,000$ per annum. German sales are somewhat less than the English, reaching $\$ 449,000$ per annum: they are also declining slightly (from $\$ 454,000$ in the earlier period).

On the whole, then, the position in regard to the competition for the iron and steel market in Central America and Colombia is as follows:-In machinery and tools the United States is well in the lead, our exports reaching $\$ 1,170,000$ per annum while those of England and Germany together amount to only $\$ 774, \infty$. Ours have increased 66 per cent. between the two periods; England's 54 per cent., and Germany's 47 per cent. In general structural material, railway material, and miscellaneous manufactures, likewise, we hold the bulk of the trade and are increasing the lead. Our exports amount to $\$ r, 347, \infty 00$ per annum and have increased 56 per cent. between the two periods. Germany and England together sell only $\$ 949,000$ worth per annum, 
and their sales are practically stationary, having declined 3 per cent. since the first period.

\section{Miscellaneous Manufactures}

The figures for the total trade in these other manufactures have already been given in a previous chapter. They show an increase in American business similar to that in our export of iron and steel. The items which make up the total are so miscellaneous that comparison in detail with European countries is unfortunately impossible except as regards a few classes of articles. Among these may be mentioned candles, glass and glassware, chemicals and chemical preparations, medicines, drugs, etc., paints and varnishes, soap, rubber manufactures, cement, copper manufactures, paper and paper manufactures, etc. So far as comparisons are possible the condition of the trade in these goods is shown in the following table: 
EXPORTS OF MISCELLANEOUS MANUFACTURES TO CENTRAL AMERICA AND COLOMBIA

Annual averages in thousands of dollars

\begin{tabular}{|c|c|c|c|c|c|c|c|c|}
\hline & \multicolumn{2}{|c|}{ Untrze States } & \multicolumn{2}{|c|}{ UNITED KNGDOM } & \multicolumn{2}{|c|}{ Grewury } & \multicolumn{2}{|c|}{ Francz } \\
\hline & $\begin{array}{c}\text { Ist } \\
\text { period }\end{array}$ & $\begin{array}{l}\text { 2nd } \\
\text { period }\end{array}$ & $\begin{array}{c}\text { rst } \\
\text { period }\end{array}$ & $\begin{array}{l}\text { and } \\
\text { reriod }\end{array}$ & $\begin{array}{c}\text { rst } \\
\text { period }\end{array}$ & $\begin{array}{l}\text { and } \\
\text { period }\end{array}$ & $\begin{array}{c}\text { rst } \\
\text { period }\end{array}$ & $\begin{array}{l}\text { and } \\
\text { period }\end{array}$ \\
\hline Candles....... & 30 & 32 & 45 & 27 & 5 & 0 & & \\
\hline Soap......... & $125^{2}$ & $100^{2}$ & ro & 37 & $24^{2}$ & $5^{2}$ & $61^{2}$ & $94^{2}$ \\
\hline $\begin{array}{c}\text { Glass and } \\
\text { Glassware. }\end{array}$ & 51 & 45 & 9 & 15 & 39 & 64 & $36^{1}$ & $6 x^{1}$ \\
\hline $\begin{array}{r}\text { Chemicals and } \\
\text { c b e m i c a l } \\
\text { preparations. }\end{array}$ & $\begin{array}{l}180^{\circ} \\
206\end{array}$ & $\begin{array}{l}255 \\
276\end{array}$ & 22 & 64 & & & 4 & 9 \\
\hline $\begin{array}{l}\text { Drugs, medi- } \\
\text { cines, etc... }\end{array}$ & 146 & 258 & 38 & 46 & 106 & 237 & 262 & 274 \\
\hline Paints, etc. ... & 59 & 76 & 21 & 28 & 5 & 4 & & \\
\hline Rubber mfs... & $3 x$ & so & 22 & 18 & $4 x$ & 32 & 0 & 2 \\
\hline Cement...... & 13 & 31 & $1 / 2$ & 0 & 15 & 28 & & \\
\hline $\begin{array}{l}\text { Copper mfs... } \\
\text { Paper and pa. }\end{array}$ & $94^{3}$ & $170^{2}$ & 19 & 16 & 133 & so & & \\
\hline per mfs..... & 132 & 147 & & & 80 & 164 & 69 & 124 \\
\hline
\end{tabular}

1 Includes pottery.

2 Includes perfumery.

- Includes brass and electrical instruments and appliances.

- Explosives.

The most important items of export from the United States, of this general class of miscellaneous manufactures, are chemicals and chemical preparations, drugs, medicines, etc., our sales reaching $\$ 532,000$ and $\$ 789,000$ per annum for the two periods 1902-1906 and 1907-191 I respectively. These amounts considerably exceed the sales of England, Germany, and France together. But our business, though increasing more rapidly than the French, is losing ground relatively to the English and German. Between the two 
periods our exports increased 48 per cent.; England's, 83 per cent.; and Germany's, I23 per cent.

Our next largest item is copper manufactures. In this we are far more than holding our own. In the first period our sales were less than two-thirds as large as England's and Germany's: in the second, we sent two-and-one-half times as much as those two countries together.

In the paper trade we are losing ground. Our sales increased it is true, between the two periods, but the rate of increase is only II per cent., while French sales nearly doubled in value, and German more than doubled.

In candles, soap, paints, rubber manufactures, and cement we also hold a larger share of the trade than any other single country, and in all of them except soap our sales are gaining ground. Our sales of soap have declined in absolute amount while English and French have increased so rapidly that the two together now exceed ours by over 30 per cent. In glassware also our trade has declined while English, French, and German have all largely increased; 67 per cent. for England; 64 for Germany; and 70 for France.

So far, therefore, as comparisons are possible concerning the separate items of miscellaneous manufactures, the figures indicate that the United States is successfully competing only in chemicals, medicines, etc., paints, copper manufactures, rubber manufactures, and candles. Germany and France are absorbing a larger share of the glass traie and the paper trade; and France and England, of the soap trade. 


\section{MeXico}

\section{A. Foodstuffs}

American exports of this sort to Mexico averaged $\$ 5,472,000$ per annum in 1902-1906 and $\$ 9,173,000$ in 1907I9I I. The largest items are breadstuffs, $\$ 3,860,000$ in 1907I9II; provisions and dairy products, $\$ 2,047, \infty 00$; and cotton seed oil, $\$ 1,500, \infty 00$. All three are increasing, but the greatest gain is in breadstuffs- 19 per cent. between the two periods. Provisions and dairy products have increased 72 per cent.; and cotton seed oil 56 per cent. Corn and wheat account for the greatest increase in breadstuffs; bacon, ham, lard, and lard compounds, in provisions; and butter, in dairy products.

English sales are so small as to be practically negligible, the only item of this general class deserving mention being spirits which were exported to the value of $\$ 44,000$ per annum in 1902-1906 and $\$ 54,000$ in 1907-1911. Germany's small export of $\$ 320,000$ and $\$ 430,000$ per annum for the two periods respectively is chiefly made up beer and wine; and those of France, $\$ 8 \infty, \infty \infty$ and $\$ 1, \infty \infty, \infty \infty$, mostly of wines and spirits.

There is, therefore, but little competition between the United States and Europe. American exports of beer, wines, and spirits are small and declining, the aggregate of these items being \$241,000 per annum in 1902-1906 and only $\$ 159,000$ in 1907-1911. French, German, and English exports of this kind increased from $\$ 1,164,000$ to $\$ 1,584, \infty 00$. 


\section{B. Clothing and Clothing Materials}

Somewhat over one-half of the American export under this heading consists of boots and shoes. About one-fourth of the total is cotton goods and the remainder mainly woolen and silk goods. All are increasing, but none rapidly except boots and shoes. These have grown from an average of $\$ 940,000$ per annum in I902-I906 to $\$ 1,480,000$ in I907rgrr. The chief items and the trend of competition are shown in the following table:

\section{EXPORTS TO MEXICO OF CLOTHING AND CLOTHING MATERIALS}

Annual averages in thousands of dollars

\begin{tabular}{|c|c|c|c|c|c|c|c|c|}
\hline & \multicolumn{2}{|c|}{ United States } & \multicolumn{2}{|c|}{ UNITED KINGDOM } & \multicolumn{2}{|c|}{ GERMANY } & \multicolumn{2}{|c|}{ France } \\
\hline & $\begin{array}{c}\text { Ist } \\
\text { period }\end{array}$ & $\begin{array}{c}2 \text { nd } \\
\text { period }\end{array}$ & $\begin{array}{c}\text { Ist } \\
\text { period }\end{array}$ & $\begin{array}{l}\text { 2nd } \\
\text { period }\end{array}$ & period & $\begin{array}{l}\text { 2nd } \\
\text { period }\end{array}$ & $\begin{array}{c}\text { rst } \\
\text { period }\end{array}$ & $\begin{array}{c}\text { 2nd } \\
\text { period }\end{array}$ \\
\hline Cotton cloths. & 240 & 220 & 2047 & 2.268 & 020 & 038 & 560 & 8 II \\
\hline Other cotton mfs... & 280 & 260 & 2,941 & 3,200 & $y<9$ & 930 & 500 & 012 \\
\hline Silk manufactures... & 84 & II 7 & 39 & 44 & 225 & 338 & $3^{67}$ & 309 \\
\hline Woolen mfs. & 300 & 380 & 633 & 740 & 605 & 443 & $6 \mathrm{r} 8$ & 914 \\
\hline Clothing.... & $220^{1}$ & $300^{1}$ & $39^{2}$ & $58^{2}$ & $146^{2}$ & I $24^{2}$ & $309^{2}$ & $328^{2}$ \\
\hline Boots and shoes..... & 940 & $\mathrm{I}, 480$ & & & & & I74 3 & $x \times 6^{3}$ \\
\hline
\end{tabular}

${ }^{1}$ Cotton clothing.

${ }^{2}$ All clothing.

${ }^{3}$ All leather and manufactures of.

In the total export of all these goods together England exceeds any other country by a considerable margin. This is mainly due to the large sales of cotton manufactures. In silk manufactures Germany leads; in woolens, France; and in boots and shoes, the United States. The figures for clothing also show France in the lead, but as the French 
figures include all clothing while the American are for cotton clothing alone, and as America's exports appear as being but slightly behind the French, it is probable that if American exports of other clothing were separately stated and could be included, the United States would be found to be in the lead. In cottons, the United States is distinctly losing ground, our sales having declined even in absolute amount (from $\$ 520,000$ per annum to $\$ 480, \infty 00$ ) while English, French, and German sales have increased I1, 45, and I per cent., respectively. The great advance of France in the face of English and German competition is noteworthy.

Equally noteworthy is Germany's advance in the silk trade. France, which in the first period, held the first place, suffered a considerable falling off in the second period ( 6 per cent.), while Germany increased its share by 50 per cent., and took the lead. The English business is small, but increasing somewhat; the American is about one-third of Germany's but is increasing nearly as fast as that country's.

French advance in woolens is also surprising. The United States, England, and France have all three increased their business, but France by far the most rapidly. From second place, with sales slightly behind those of England and slightly ahead of those of Germany, France rose in the second period to first place with an export nearly a quarter larger than England's and more than twice as large as Germany's. The United States is gaining relatively to England and Germany but losing relatively to France. Our 
sales are about one-half as large as England's and nearly as large as Germany's.

In clothing, as already stated, the figures are not altogether comparable as our figures include only cotton clothing while those of the other countries are for cotton, woolen, silk, and linen clothing as well. It is clear, however, that the United States is making good headway in this line. Our chief competitor is France, but American sales have increased 36 per cent., while French have risen by only 6 per cent.

In boots and shoes we appear to have no serious competitor. English and German exports are not separately stated, but are small. The French figures which include all leather manufactures and therefore are larger than they should be, are only about one-thirteenth of ours and are declining. Ours, on the other hand, show a remarkable increase of 57 per cent. between the two periods.

On the whole, then, it is apparent that the United States is more than holding its own in boots and shoes and readymade clothing, and is making headway against England and Germany, but not against France, in woolen goods. In silks also our position is not discouraging. England is losing relatively in all the items, and Germany, in all but silks. France is making a remarkable gain in both cottons and woolens.

\section{Iron and Steel Manufactures}

Again it will be found useful to divide into several classes in making our comparisons: general structural materials, 
railway materials, machinery and tools, and miscellaneous manufactures.

EXPORTS OF IRON AND STEEL MANUFACTURES TO MEXICO Annual averages in thousands of dollars

\begin{tabular}{|c|c|c|c|c|c|c|}
\hline & \multicolumn{2}{|c|}{ Untrzo Statzs } & \multicolumn{2}{|c|}{ UnTrED KmaDOM } & \multicolumn{2}{|c|}{ Geneaxy } \\
\hline & $\begin{array}{c}\text { rst } \\
\text { period }\end{array}$ & $\begin{array}{l}\text { and } \\
\text { period }\end{array}$ & $\begin{array}{c}\text { Ist } \\
\text { period }\end{array}$ & $\begin{array}{l}\text { 2nd } \\
\text { period }\end{array}$ & $\begin{array}{c}\text { rst } \\
\text { period }\end{array}$ & $\begin{array}{l}\text { and } \\
\text { period }\end{array}$ \\
\hline General structural materials & 2,494 & 4,074 & & & & \\
\hline Railway materials. . . . . . . . & 2,720 & 3,720 & & & & \\
\hline Machinery and tools....... & 8,166 & 10,639 & $\mathbf{1}, 373$ & 1,831 & 862 & $\mathbf{r}, 6 \mathbf{1 8}$ \\
\hline Miscellaneous manufactures & 2,800 & 3,600 & 1,817 & 1,714 & $\mathbf{1}, 827$ & $x, 676$ \\
\hline Total.... & 16,180 & 22,033 & 3,190 & 3,545 & 2,689 & 3,294 \\
\hline
\end{tabular}

French exports are so small compared with those of the United States, England, and Germany that they may be omitted. Of these three competitors England is obviously losing ground relatively to the others. The classification is so incomplete as to render it impossible to make satisfactory comparisons except as to machinery, tools, etc. In this trade the United States, although exporting three times as much as England and Germany together, is losing a little relatively. Our sales have increased between the two periods only 30 per cent., while England's have risen 33 per cent., and Germany's 88 per cent. But in general structural materials, railway materials, and miscellaneous manufactures together, England and Germany not only have a very small share of the business (less than onethird that of the United States) but even this small share is declining, England's 6 per cent, and Germany's 8 per 
cent., while ours has grown by 42 per cent. The largest part of this growth is due to general structural materials, the sales having increased 63 per cent., while railway materials rose 37 per cent., and miscellaneous manufactures, 29 per cent.

The separate items which make up these general classes of American export to Mexico are of interest because they show more clearly the specific lines along which we are able to meet European competition under favorable conditions. The following table gives the most important of them. 
EXPORTS OF IRON AND STEEL FROM THE UNITED STATES TO MEXICO

Annual averages in thousands of dollars

\begin{tabular}{|c|c|c|c|}
\hline & $1002-1006$ & $1907-1918$ & $\begin{array}{l}\text { Percentage } \\
\text { of iacrease }\end{array}$ \\
\hline \multicolumn{4}{|l|}{ General structural materials: } \\
\hline 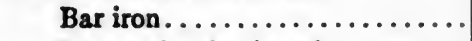 & 97 & 77 & \\
\hline Bars and rods of steel. .......... & 77 & 117 & 52 \\
\hline Structural iron and steel. . . . . . . & 420 & 960 & 128 \\
\hline 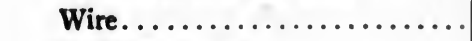 & 500 & 820 & 64 \\
\hline Castings, n. e. s. . . . . . . . . . . & 200 & 200 & \\
\hline Nails and spikes............. & 180 & 260 & 44 \\
\hline Pipes and fittings........... & 1,020 & $x, 640$ & 61 \\
\hline \multicolumn{4}{|l|}{ Railway materials: } \\
\hline Cars for steam railways. ....... & 900 & $x, 160$ & 29 \\
\hline Cars for other railways......... & 140 & 260 & 86 \\
\hline Steel rails............... & 760 & 1,580 & 108 \\
\hline 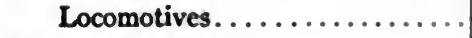 & 920 & 720 & \\
\hline \multicolumn{4}{|l|}{ Machinery, lools, elc.: } \\
\hline $\begin{array}{l}\text { Plows and cultivators........... } \\
\text { All other agricultural implements }\end{array}$ & 120 & 180 & 50 \\
\hline 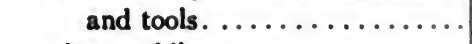 & 240 & 340 & 42 \\
\hline 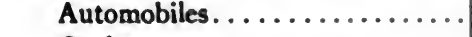 & 140 & 540 & 286 \\
\hline Cycles.................... & $5 \mathrm{I}$ & 74 & 45 \\
\hline "All other" cars, carriages, etc. . & 440 & 500 & 14 \\
\hline Saws, tools and hardware ${ }^{1} . . .$. & 820 & 1,120 & 37 \\
\hline Firearms................. & 140 & 200 & 43 \\
\hline Electrical machinery....... & 660 & $1, \infty 0$ & 6I \\
\hline Metal working machinery....... & 75 & $\mathbf{I 2 2}$ & 63 \\
\hline Pumps and pumping machinery . & 520 & 580 & 12 \\
\hline Sewing machines......... & 540 & 583 & 8 \\
\hline "Other" steam engines. . & 460 & 560 & 22 \\
\hline Typewriters........... & 220 & 320 & 45 \\
\hline Mining machinery. .... & 3 & 2,180 & ) \\
\hline All other machinery $\ldots \ldots \ldots \ldots$ & 3,740 & 2,280 & 19 \\
\hline Miscellaneous manufactures. . . . . . . . & 2,800 & 3,600 & 29 \\
\hline Tot & 16,180 & 22,033 & \\
\hline
\end{tabular}

1 Hardware should, of course, properly be included in structural material, but is not separately stated.

"Included in "all other machinery" in the first period. 
It will be noticed that in the entire list only two items, bar iron and locomotives, fail to show an increase; and that for most of the items the growth has been very rapid. On the whole the export business in iron and steel with Mexico is in a flourishing condition.

\section{Miscellaneous Manufactures}

Here, as in the case of Central America, it is impossible to make complete comparisons as to many details, because of the incompleteness of the statistics, but in regard to a number of the items concerning which the figures are reasonably full, the United States seems to be making good headway. The figures are: 
EXPORTS TO MEXICO OF MISCELLANEOUS MANUFACTURES

Annual averages in thousands of dollars

\begin{tabular}{|c|c|c|c|c|c|c|c|c|}
\hline & \multicolumn{2}{|c|}{ United States } & \multicolumn{2}{|c|}{$\begin{array}{c}\text { UNITED } \\
\text { KINGDOM }\end{array}$} & \multicolumn{2}{|c|}{ Graxary } & \multicolumn{2}{|c|}{ Fenvers } \\
\hline & $\begin{array}{c}\text { sst } \\
\text { period }\end{array}$ & $\begin{array}{l}\text { 2nd } \\
\text { period }\end{array}$ & $\begin{array}{c}\text { Ist } \\
\text { period }\end{array}$ & $\begin{array}{l}\text { and } \\
\text { period }\end{array}$ & $\begin{array}{c}\text { ist } \\
\text { period }\end{array}$ & $\begin{array}{l}\text { 2nd } \\
\text { period }\end{array}$ & period & period \\
\hline 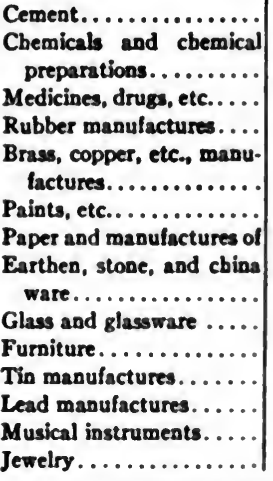 & $\begin{array}{l}100 \\
2,015^{1} \\
220 \\
300 \\
580 \\
160 \\
731 \\
120 \\
420 \\
640 \\
105 \\
80 \\
178 \\
61\end{array}$ & $\begin{array}{c}200 \\
2,202 \\
300 \\
580 \\
620 \\
220 \\
860 \\
260 \\
160 \\
780 \\
102 \\
180 \\
212 \\
72\end{array}$ & $\begin{array}{r}63 \\
536 \\
29 \\
107 \\
44 \\
4\end{array}$ & $\begin{array}{r}161 \\
1.070 \\
34 \\
54 \\
54 \\
54\end{array}$ & $\begin{array}{c}95 \\
700 \\
138 \\
378 \\
242 \\
195 \\
368 \\
20 \\
27 \\
9203\end{array}$ & $\begin{array}{r}242 \\
1,205 \\
100 \\
240 \\
352 \\
148 \\
368 \\
22 \\
14 \\
362\end{array}$ & $\begin{array}{c}155^{2} \\
58\end{array}$ & $\begin{array}{r}58 \\
465 \\
77 \\
38 \\
990\end{array}$ \\
\hline
\end{tabular}

1 Includes explosives, $\$ 1,120,000$ and $\$ 920,000$ for the two periods respectively.

Includes pottery.

Includes all manufactures of the precious metals.

- Changes in classification render a comparison particularly difficult, but the German business is probably somewhat larger than the American$\$ 219,000$ per annum in 1902-1905.

The largest items are chemicals, drugs, medicines, etc. The sales of the United States are far ahead of those of any other country; but there is a tendency to decline. American exports increased between the two periods by only 12 per cent., while the English rose 95 per cent.; the German, 72; and the French, 8o. English and German gains are in chemicals; those of France, in drugs and medicines. In copper and brass, paints, earthenware, etc., glass, furniture, lead, and musical instruments, the United States not only 
leads but is also more than holding its own against those countries for which comparisons are possible. In paper and tin, on the other hand, though we still lead, others are gaining. In regard to paper our sales are larger than German and French combined, yet while ours have increased only I8 per cent., Germany's have risen 46 per cent., and France's 36 per cent.

\section{The West Coast of South America}

In trade with the two groups of countries thus far examined the United States possesses certain rather important advantages due to greater proximity than the European competitors. It is not surprising therefore that American exporters have on the whole been making a good showing there. With regard to the west coast of South America, however, such advantages hitherto have not existed except in trade in light and valuable goods which have gone from our Atlantic sea board to Ecuador and northern Peru via Panama. Facilities, on the whole, may be regarded as being much more evenly divided between the American and European competitors in these markets than in Mexico and Central America, and an examination of their activities in recent years is, therefore, of particular interest.

\section{A. Foodstuffs}

The chief American export of foodstuffs to these countries is, naturally, of breadstuffs, $\$ 894,000$ per annum in I902-1906, and $\$ 1,099,000$ in I907-I9II. Provisions, dairy products, etc., make up most of the remainder, 
reaching the value of $\$ 695, \infty 00$ and $\$ 1,248,000$ per annum for the two periods respectively. In addition there are small amounts of tobacco manufactures, wines, etc. These figures are very significant of an important change which is going on. Not only is it evident that breadstuffs play a far less important part in our exports of foodstuffs to these South American countries than to Mexico, Central America, and Colombia, but that they are also declining relatively to other foodstuffs. In the first period they constituted 54 per cent. of our foodstuffs export; in the second, only 46 per cent. Meantime provisions, dairy products, etc., rose from 42 per cent. of the total, to 52 per cent. The chief item in this growing trade in provisions, etc., is lard, which rose from $\$ 433, \infty 00$ per annum to $\$ 694, \infty \infty$. Fish, of which the chief item is canned salmon, comes next, with an increase from $\$ 143,000$ to $\$ 25^{2}, 000$ per annum. Other meat and dairy products are a smaller item but show a good increase, from $\$ 108,000$ to $\$ 280, \infty 00$.

The chief article of British export under this general heading is spirits, the values for the two periods amounting to $\$ 157,000$ and $\$ 244, \infty 00$ per annum. There is also a small but growing trade in biscuit and cakes ( $\$ 49, \infty 00$ per annum), in condensed milk $(\$ 97, \infty \infty)$, in aërated waters $(\$ 39, \infty)$ and in "provisions, unenumerated," $(\$ 24, \infty)$.

Nearly 70 per cent. of the French exports of this class are wines and spirits, the former of course largely predominating. The wine export reaches $\$ 216,000$ and $\$ 289,000$ per annum for the two periods respectively and the spirits export, $\$ 65, \infty 00$ and $\$ 147, \infty 00$. All other items are insignif- 
icant in value, the chief ones being vegetables $(\$ 60,000$ per annum), tobacco manufactures $(\$ 40,000)$, meats $(\$ 36,000)$, and confectionery $(\$ 24, \infty 00)$. All of these show an increasing export.

Neither England nor France, therefore, can be said to compete with the United States in the matter of foodstuffs proper. Germany, however, does; for, excluding wines, spirits, beer, and tobacco, her exports of foods reaches the very considerable totals of $\$ 764,000$ per annum for I902I906, and \$1,587,000 for 1907-r9r I. The American figures excluding the small exports of wines, spirits, tobacco, etc., and of breadstuffs in which Germany does not compete, are $\$ 736,000$ per annum for 1902-1906 and $\$ 1,264,000$ for 1907-I9II. German trade, therefore, in the commodities in which competition may be said to exist, is somewhat larger than ours and is gaining. American sales have increased 72 per cent.; German, 108 per cent. The chief items in this German trade are: sugar, $\$ 435,000$ per annum; rice and rice starch, $\$ 298,000$; beer, wine, spirits, etc., $\$ 140,000$; the increase between the two periods being due mainly to growing sales of rice and sugar. 


\section{B. Clothing and Clothing Materials}

EXPORTS OF CLOTHING AND CLOTHING MATERIALS TO WEST COAST OF SOUTH AMERICA

Annual averages in thousands of dollars

\begin{tabular}{|c|c|c|c|c|c|c|c|c|}
\hline & \multicolumn{2}{|c|}{ UNTTED STATES } & \multicolumn{2}{|c|}{ Untred Krngdox } & \multicolumn{2}{|c|}{ Germanx } & \multicolumn{2}{|c|}{ Fruver } \\
\hline & $\begin{array}{c}\text { sst } \\
\text { period }\end{array}$ & $\begin{array}{c}\text { 2nd } \\
\text { period }\end{array}$ & $\begin{array}{c}\text { ist } \\
\text { period }\end{array}$ & $\begin{array}{l}\text { 2nd } \\
\text { period }\end{array}$ & $\begin{array}{c}\text { Ist } \\
\text { period }\end{array}$ & $\begin{array}{c}\text { 2nd } \\
\text { period }\end{array}$ & period & $\begin{array}{c}\text { 2nd } \\
\text { period }\end{array}$ \\
\hline Cottons, colored. . . & 272 & 185 & & & & & & \\
\hline Cottons, uncolored. & 608 & 758 & 8,605 & 10,134 & 3,019 & 3,425 & 672 & 822 \\
\hline Cottons, other.... & 51 & 95 & & & & & & \\
\hline Boots and shoes '. & 23 & 56 & & & & & & \\
\hline Apparel $2 \ldots . .$. & & & 232 & 356 & 416 & 706 & 379 & 560 \\
\hline Linens. . . . . . . . . . & & & 156 & 268 & & & & \\
\hline Woolens...... . & & & 2,601 & 3,974 & 1.594 & 2,245 & 405 & 876 \\
\hline Haberdashery..... & & & 54 & 43 & & & & \\
\hline Hats........ & & & 63 & 92 & & & $133^{\circ}$ & $128^{\circ}$ \\
\hline Silks........ & & & 58 & 73 & 260 & 522 & $\mathbf{1 3 9}$ & 259 \\
\hline
\end{tabular}

Includes certain other small items of leather manufacture.

2 Includes other than cotton.

- Includes straw for hats.

It is evident that the United States is making but little progress in any branch of this trade. Only in cottons do we seem to have entered the competition at all and even in these goods our sales are insignificant compared with those of England or Germany. Germany's export is over three times as large as ours and England's nearly ten times as large. English sales have increased 18 per cent. between the two periods; German 13 per cent.; American only II per cent. French trade in cottons is even smaller than ours.

The woolen trade is relatively of much greater importance in these countries than in Mexico or Central America. England and Germany are the chief competitors, the former being well in the lead and increasing its advantage 
slightly. Between the two periods English sales increased 53 per cent.; the German, only $4^{2}$ per cent. French exports increased far more rapidly than either of these but the total is small-about one-fifth of England's.

In apparel and in silks, France becomes an important competitor, ranking next to Germany in both these items, while England occupies third place. Both these lines of business are growing rapidly and all these countriesEngland, Germany, and France-are sharing the increase, but on the whole Germany is gaining. German export of apparel rose 70 per cent., and of silks, Ioo per cent., between the two periods. Neither France nor England approached these figures.

The other small items in the table do not require any special comment here.

C. Iron and Steel Manufactures

EXPORTS OF IRON AND STEEL MANUFACTURES TO THE WEST COAST OF SOUTH AMERICA

Annual averages in thousands of dollars

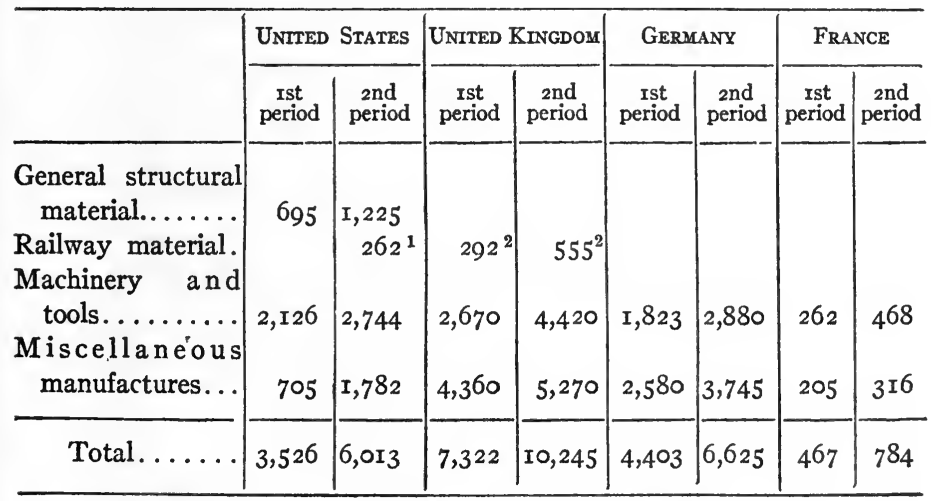

${ }^{1}$ Steel rails.

${ }^{2}$ Carriages for steam railways. 
French competition here is negligible. In regard to the other three countries a direct comparison is possible only in the case of machinery, tools, etc. All three countries are gaining rapidly in absolute value of their sales, but relatively the United States is losing while England and Germany are gaining, the former the more rapidly. English sales increased 65 per cent. between the two periods; German, $5^{8}$ per cent.; American, only 29 per cent. It is in other than machinery exports that the United States is making headway. Our sales of miscellaneous iron and steel and structural and railway materials have grown from $\$ 1,400,000$ per annum to $\$ 3,269, \infty 00$, an increase of 134 per cent. English and German sales of this class are larger than ours but we seem to be rapidly overtaking them, for Germany's have increased only 45 per cent., and England's only 25 per cent. Our sales which in 1902-1906 were only about one-third of England's and not much over one-half of Germany's reached, in 1907-1911, 56 per cent. of England's and 88 per cent. of Germany's. The details of American export so far as separately stated in our trade statistics are: 
EXPORTS OF IRON AND STEEL MANUFACTURES FROM THE UNITED STATES TO THE WEST COAST OF SOUTH AMERICA

Annual averages in thousands of dollars

\begin{tabular}{|c|c|c|}
\hline & $1902-1906$ & I907-I9II \\
\hline Bars or rods of steel. . & $\ldots{ }^{1}$ & 34 \\
\hline Sheets and plates..... & $\ldots 1$ & 86 \\
\hline Structural iron and steel. ................. & 50 & 149 \\
\hline Nails and spikes. ...................... & II5 & 161 \\
\hline Pipes and fittings.$\ldots \ldots \ldots \ldots \ldots \ldots \ldots \ldots$ & $I_{4} \mathrm{I}$ & I85 \\
\hline Locks, hinges, and hardware................ & 248 & 308 \\
\hline Wire.$\ldots \ldots \ldots \ldots \ldots \ldots \ldots \ldots \ldots \ldots \ldots \ldots \ldots \ldots$ & I4I & 302 \\
\hline Steel rails. . . . . . . . . . . . . . . . & $\ldots$ & 262 \\
\hline Agricultural implements, etc............... & 275 & 446 \\
\hline Cycles, cars, carriages, etc............... & 333 & 530 \\
\hline 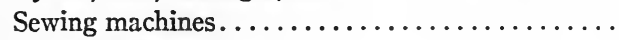 & 92 & I55 \\
\hline Steam engines. . . . . . . . . . . . . . . & 249 & $38 I$ \\
\hline Typewriters...................... & 47 & 95 \\
\hline Electrical machinery................ & 67 & 43 \\
\hline 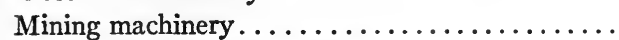 & $\ldots{ }^{2}$ & 77 \\
\hline Pumps and pumping machinery.............. & $\ldots{ }^{2}$ & 38 \\
\hline Other machinery..$\ldots \ldots \ldots \ldots \ldots \ldots \ldots$ & $\mathrm{I}, \mathrm{r} 6_{3}$ & 989 \\
\hline Plated ware $\ldots \ldots \ldots \ldots \ldots \ldots \ldots \ldots \ldots$ & 33 & 38 \\
\hline 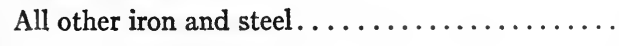 & 672 & $\mathrm{I}, 744$ \\
\hline Total. & 3,626 & 6,023 \\
\hline
\end{tabular}

${ }^{1}$ Included in "all other iron and steel" in r902-1906.

2 Included in "all other machinery" in $1902-1906$.

All of these items except electrical machinery and "all other" machinery show a handsome increase between the two periods and give an indication of the lines along which American business shows a tendency to expand.

\section{Miscellaneous Manufactures}

The figures for such items in this general category as are at all comparable are given in the following table: 
EXPORTS OF MISCELLANEOUS MANUFACTURES TO THE WEST COAST OF SOUTH AMERICA

Annual arerages in thousands of dollars

\begin{tabular}{|c|c|c|c|c|c|c|c|c|}
\hline & \multicolumn{2}{|c|}{$\begin{array}{l}\text { UnTrED } \\
\text { STATES }\end{array}$} & \multicolumn{2}{|c|}{$\begin{array}{c}\text { UNTTED } \\
\text { KINGDOK }\end{array}$} & \multicolumn{2}{|c|}{ Germuxy } & \multicolumn{2}{|c|}{ Feunca } \\
\hline & $\begin{array}{c}\text { sst } \\
\text { period }\end{array}$ & $\begin{array}{l}\text { 2nd } \\
\text { period }\end{array}$ & ist & period & $\begin{array}{c}\text { ist } \\
\text { period }\end{array}$ & $\begin{array}{l}\text { 2nd } \\
\text { period }\end{array}$ & $\begin{array}{c}\text { sst } \\
\text { period }\end{array}$ & period \\
\hline Copper manufactures. & 28 & 33 & $200^{2}$ & $302^{2}$ & 555 & 334 & 4 & 4 \\
\hline Lead manufactures. & 20 & 21 & & & 50 & 71 & & \\
\hline Scientific instruments, & & & & & & & & \\
\hline etc.............. & 211 & 306 & $248^{2}$ & $195^{2}$ & & & 39 & 66 \\
\hline Lamps, chandeliers, etc. & 35 & 39 & & & & & & \\
\hline Clocks and watches.... & 74 & 36 & & & & & 12 & 23 \\
\hline Zinc manufactures..... & & & & & 44 & 39 & & \\
\hline Tin manufactures..... & & & & & 33 & 51 & & \\
\hline Paper manufactures ${ }^{3} .$. & 346 & 549 & 123 & 185 & 640 & 844 & 147 & 205 \\
\hline Medicines, etc. ....... & 230 & 378 & 117 & 142 & & 56 & 147 & 197 \\
\hline Chemicals, etc......... & $192^{4}$ & $35^{\prime}$ & 263 & 312 & 713 & & & 27 \\
\hline Perfumery, cosmetics & & & & & & & & \\
\hline and soap...... & 122 & 179 & $15^{\circ}$ & $14^{\circ}$ & $9 x^{2}$ & $160^{\circ}$ & 85 & 104 \\
\hline Glass and glassware. . . & 38 & 47 & & & 602 & 760 & 1080 & $135^{\circ}$ \\
\hline Rubber manufactures. . & $5 \mathrm{I}$ & 92 & 73 & 88 & 229 & 224 & 23 & 50 \\
\hline Leather............. & $133^{\circ}$ & $472^{\circ}$ & $214^{\circ}$ & $370^{\circ}$ & $655^{\circ}$ & $785^{\circ}$ & $251^{\circ}$ & 530 \\
\hline Candles............... & 4 & 1 & 204 & 375 & & & & \\
\hline Cement.............. & & & 97 & 156 & & & & \\
\hline Paints, etc........... & & & 282 & 380 & & & 19 & 23 \\
\hline China and earthenware. & & & 204 & 332 & 296 & $22 \mathrm{r}$ & & \\
\hline Cordages and twine... & & & 175 & 234 & & & & \\
\hline Jute piece goods. . & & & 195 & 232 & & & & \\
\hline Seed oil. . & & & 141 & 209 & & & & \\
\hline Oil cloth. . & & & 78 & 122 & & & & \\
\hline Stationery (ex. paper). . & & & 117 & 151 & & & & \\
\hline Wood manufactures ... & $103^{11}$ & $248^{11}$ & $\ldots$ & 122 & $158^{7}$ & $242^{7}$ & $440^{20}$ & $0 / 545^{10}$ \\
\hline
\end{tabular}

1 Electrical goods and appliances.

2 Includes brass manufactures.

Includes books, etc.

Includes boots and shoes.

- Includes explosives.

- Soap only.

"Includes other "Schnittstoffe."

- Includes oils, etc.

${ }^{10}$ Furniture, etc., and tabletterie.

- Includes pottery.

u "Other" manufactures of wood. 
The United States, it will be seen, is the largest exporter of only a very few of these articles; scientific instruments and apparatus, lamps and chandeliers, clocks and watches, and perfumery and cosmetics, etc. In scientific instruments, etc., our sales are growing rapidly ( 50 per cent. between the two periods), while those of our chief rival, England, have declined. In lamps and chandeliers we have made a moderate advance, but in clocks and watches we are losing. Our sales of perfumery, cosmetics, etc., have grown rapidly and we still lead, but the exports from England, Germany, and France are advancing at an even greater rate, and seem to be overtaking ours. In the trade in copper, glass, and candles, our share is so small as to be negligible; but in paper, chemicals, medicines and drugs, rubber, leather, and wood we may be said to be really competing-with varying degrees of success. We occupy second place, after Germany, in the paper trade and have increased the business by 59 per cent. between the two periods; while German sales have risen only 32 per cent.; English, 50 per cent.; and French, 39. A similar statement applies to the trade in chemicals, medicines, etc. American exports stand next to German and are increasing more rapidly, so that while Germany still does 50 per cent. more business in these goods than the United States, the latter bids fair to overtake the former. England's smaller export is increasing even more slowly than Germany's; and France's though increasing at about the same rate as Germany's, is also, in comparison with the United States, declining. Our rubber trade is still farther behind Germany's, yet it too gives good 
promise of increase, having risen between the two periods from less than one-fourth of Germany's to somewhat less than one-half. English sales are nearly as large as ours but are increasing much more slowly. In leather and leather manufactures the United States occupies only third place, Germany and France coming first and second respectively. Our exports are making rapid strides, however. In the first period the United States stood fourth. The rapid increase, from $\$ 133,000$ per annum to $\$ 472,000$ has put us almost on the level of France $(\$ 530,000$ per annum in $1907-$ I9I I) and raised our share from one-fifth of that of Germany to three-fifths. Our sales have grown from 38 per cent. less than England's to 28 per cent. more than hers.

The figures for manufactures of wood are not comparable so far as absolute values are concerned for the reason that the classifications in the official documents are very different. Yet they are interesting as furnishing a clue to the relative rates of progress of the chief competitors, France, Germany, and the United States. French sales have increased 24 per cent. between the two periods; German, 53 per cent.; American, 52 per cent. Germany and the United States, therefore, appear to be making about equal progress in this class of business.

Other considerable items of miscellaneous manufactures, in all of which England holds the chief place, and in none of which the United States seriously competes at present, are candles (export from England $\$ 375,000$ per annum), cement $(\$ 156, \infty 0)$, paints, etc. $(\$ 380, \infty)$, china and earthenware $(\$ 332, \infty)$, cordage and twine $(\$ 234, \infty)$, jute piece 
goods $(\$ 232,000)$, seed oil $(\$ 209,000)$, oil cloth $(\$ 122,000)$, and stationery other than paper $(\$ 151, \infty)$. These are all articles in the sale of which the United States might, conceivably, under favorable conditions take a share.

\section{China (Including Hongkong)}

For reasons already stated the best view of the trend of development in Chinese trade can be obtained by comparing periods in which the disturbances caused by the RussoJapanese war did not make themselves felt. In the following tables, therefore, the figures are given for the two periods, I897-I90I and I907-I9II as well as for the period I902-I906 within which the war fell.

\section{A. Foodstuffs}

EXPORTS OF FOODSTUFFS TO CHINA (INCLUDING HONGKONG)

Annual averages in thousands of dollars

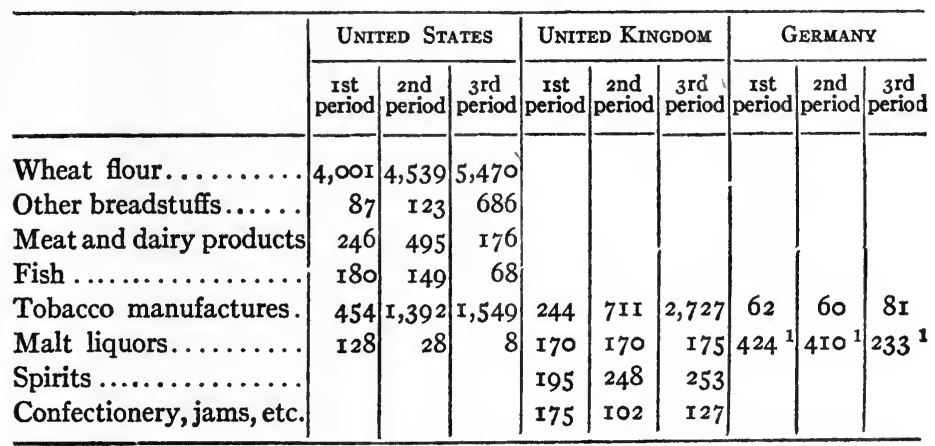

1 Includes wines.

These figures call for but little comment. The United States competes only in breadstuffs, meat and dairy prod- 
ucts, fish and tobacco. Our small trade in malt liquors has practically disappeared and numerous other minor items such as canned and dried fruits and vegetables, spirits, wine, etc., are too small to be considered at present. In breadstuffs, meat and dairy products, and fish, the United States, among the Occidental nations, holds a virtual monopoly. China imports largely from neighboring Oriental nations but with this trade we are not here concerned. In breadstuffs, American trade is growing with considerable rapidity, having increased over 50 per cent. between $1897^{-}$ I90I and 1907-1911; but the trade in meat, dairy products, and fish is declining, the former having dropped 29 per cent., and the latter, 62 per cent. between the two periods. The figures for the tobacco trade are interesting because they reflect the influence on the demand for this stimulant of the suppression of the opium traffic. American sales have increased nearly fourfold and English, over tenfold, the latter country supplying now nearly twice as much as the former. German trade in malt liquors and wines has declined rapidly probably as a result of the competition of Japanese beer, while England's trade in malt liquors and spirits has shown a moderate increase. 


\section{B. Exports of Clothing and Clothing Materials}

EXPORTS OF CLOTHING AND CLOTHING MATERIALS TO CHINA

Annual averages in thousands of dollars

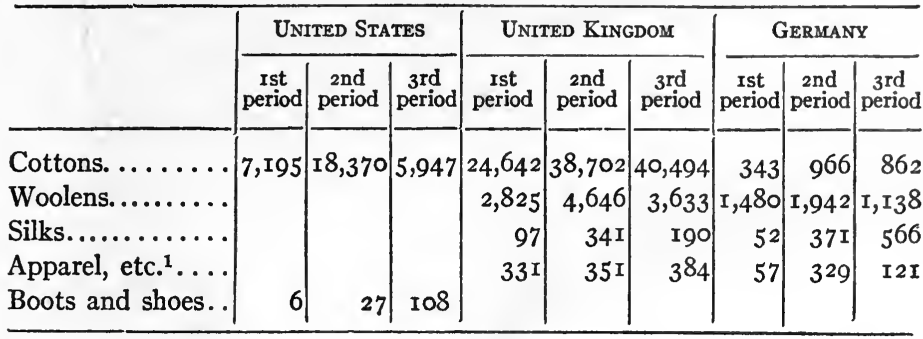

${ }^{1}$ Includes haberdashery.

The only articles of large importance are cottons and woolens, and only in the first of these does the United States play any part worthy of mention. Our trade is declining. In r897-1901, we sold nearly one-third as much as England; in I907-I9I I only one-sixth as much. German trade like England's is increasing but the value is insignificant. In woolens Germany plays a relatively more important part, but her sales are less than one-third as large as England's and are declining, while England's are increasing moderately. 


\section{Iron and Steel Manufactures}

EXPORTS OF IRON AND STEEL MANUFACTURES TO CHINA Annual averages in thousands of dollars

\begin{tabular}{|c|c|c|c|c|c|c|c|c|c|}
\hline & \multicolumn{3}{|c|}{ UNTTED Statrs } & \multicolumn{3}{|c|}{ UNTTED KMADOM } & \multicolumn{3}{|c|}{ Gezwury } \\
\hline & $\begin{array}{c}\text { sst } \\
\text { period }\end{array}$ & $\begin{array}{c}2 \text { ad } \\
\text { period }\end{array}$ & period & $\begin{array}{c}\text { rst } \\
\text { period }\end{array}$ & $\begin{array}{c}\text { and } \\
\text { period }\end{array}$ & period & $\begin{array}{c}\text { rst } \\
\text { period }\end{array}$ & $\begin{array}{c}\text { and } \\
\text { period }\end{array}$ & period \\
\hline $\begin{array}{c}\text { General structural } \\
\text { material........ }\end{array}$ & 131 & 177 & 532 & $161^{1}$ & $244^{1}$ & $204^{\prime}$ & & & \\
\hline Railway material. . & 277 & 145 & 195 & & & & & & \\
\hline Machinery and tools & 74 & 255 & 180 & $1,539^{2}$ & $1,860^{2}$ & $2,305^{2}$ & $\mathbf{x}, \mathbf{1 4 7}$ & 985 & 1,580 \\
\hline $\begin{array}{l}\text { Miscellaneous manu- } \\
\text { factures......... }\end{array}$ & 439 & 756 & 836 & 3,305 & 3,780 & 4,280 & 3,089 & 3,979 & 3,551 \\
\hline Total & 921 & 1,333 & 1,742 & $6, \infty$ & 5,884 & 6,789 & 4,236 & 4,964 & 5,131 \\
\hline
\end{tabular}

1 Hardware.

'Machinery and millwork, and implements and tools.

So far as comparisons are possible they indicate that the United States is making progress in general structural materials and in miscellaneous manufactures. Our trade in machinery and tools is small, Germany and England holding the bulk of the business; yet the increase of American trade from $\$ 74,000$ per annum in $1897-1901$ to $\$ 225,000$ in 1907-191 I indicates a possibility of development under favorable conditions. Our business in railway materials is declining: those of Germany and England are increasing, probably because of railway concessions in China, but the figures are not sufficiently complete to make a statistical comparison possible.

The details of exports of this class.from the United States to China are as follows: 
EXPORTS OF IRON AND STEEL FROM THE UNITED STATES TO CHINA, BY ARTICLES

Annual averages in thousands of dollars

\begin{tabular}{|c|c|c|c|}
\hline & Ist period & 2nd period & 3rd period \\
\hline Structural iron and steel. .......... & I6 & 37 & 47 \\
\hline 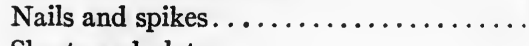 & $\operatorname{Iog}$ & 140 & 230 \\
\hline 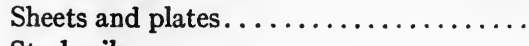 & & & I79 \\
\hline 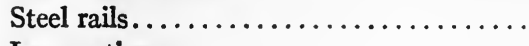 & 22 & 66 & 40 \\
\hline 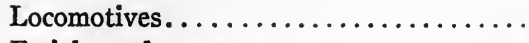 & 255 & 79 & 84 \\
\hline Freight and passenger cars....... & & & $7 \mathrm{I}$ \\
\hline Other cars, etc. . . . . . . . . . . & & & 25 \\
\hline Machinery, etc................ & 74 & 255 & I55 \\
\hline Builders' hardware, etc.............. & & & 76 \\
\hline Other iron and steel.............. & 439 & 756 & 836 \\
\hline
\end{tabular}

The entire business is so small that it would be almost negligible were it not for certain signs of growth. Nails, spikes, hardware, sheets and plates, machinery, etc., and the sundry items included in "all other iron and steel" are increasing with considerable rapidity. They may possibly represent the entering wedges into an important trade if conditions become more favorable.

\section{Miscellaneous Manufactures}

In miscellaneous manufactures as a whole the outlook for American trade would seem to be rather better, but there are many exceptions in regard to specific items. The figures are given in the following table: 


\section{EXPORTS OF MISCELLANEOUS MANUFACTURES TO CEINA}

Annual averages in thousands of dollars

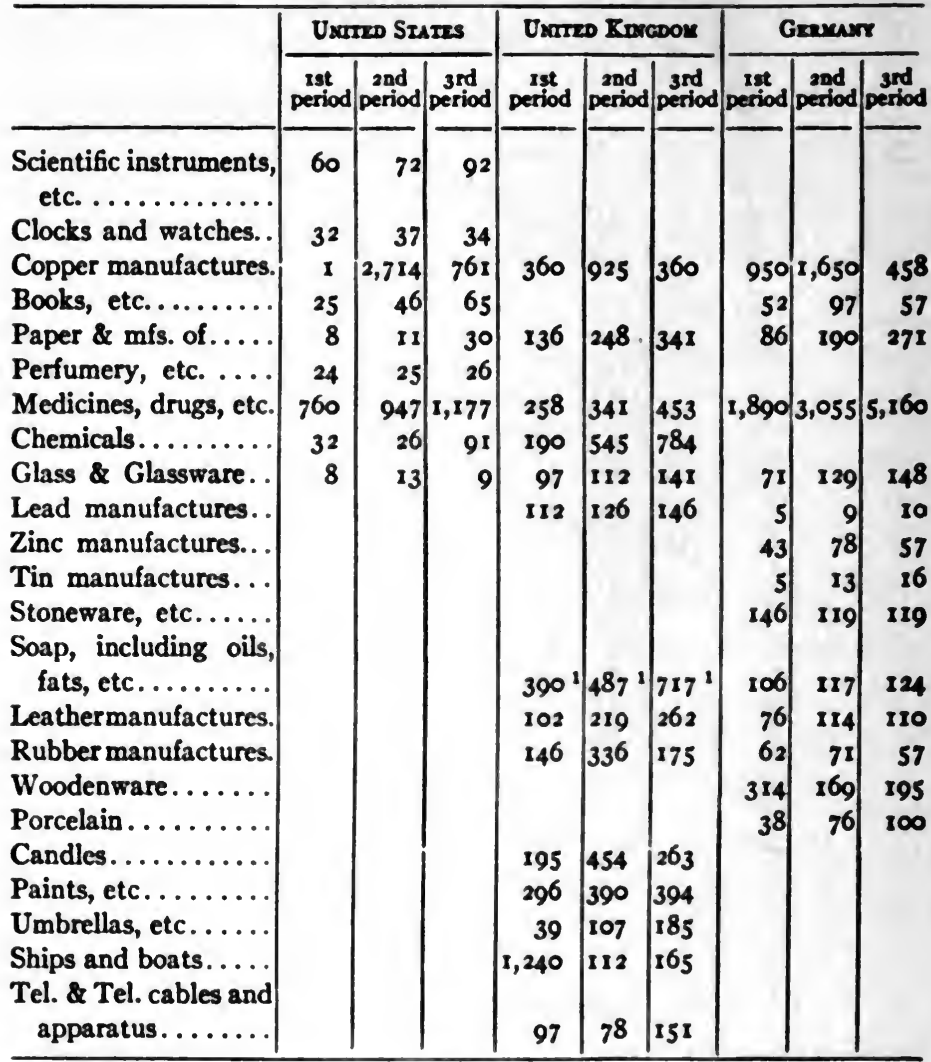

1 Soap only.

The United States, it will be observed, leads in only a few of these items, such as scientific instruments, clocks and watches, copper manufactures, books, and medicines. These are all small with the exception of copper manufactures and medicines; but most of them show a fair increase, and some of them a large increase from 1897-1901 to 1907- 
I9II. Copper manufactures show a great decline from I902-I906 to I907-I9II but this is more apparent than real because in 1902-I906 imports from both England and America were abnormally stimulated by two events: the greatly increased demand in several provinces of China which during this period coined vast quantities of copper "cash", and the Russo-Japanese war which cut off the usual source of supply in Japan. In more normal times such as the last period the supply from the United States, Germany, and England is about $\$ 1,570,000$ per annum of which the United States furnishes nearly as much as the other two countries together. The importation of medicines and drugs is growing rapidly but although this item is the largest in the list of exports from the United States and there has been a rapid increase ( 55 per cent.), yet we are greatly surpassed by Germany whose sales are not only four-and-one-half times as large as ours but have increased since I897-I90I two-and-one-half times as fast as ours. England supplies by far the largest share of chemicals, lead manufactures, soap, general leather goods, rubber goods, candles, paints, umbrellas, etc.; while Germany leads in zinc, stoneware, woodenware, porcelain, etc. The trade in paper and paper manufactures is divided between England and Germany with the former well in the lead.

\section{JAPAN}

A. Foodstuffs, etc.

The United States, as we have already seen, is the largest exporter of foodstuffs to Japan. The chief item is bread- 
stuffs, which we sold in 1897-1901 to the value of $\$ 1,025,000$ per annum. In 1907-I9I this total had risen 166 per cent. to $\$ 2,729,000$ per annum. The middle period which included the war naturally shows much larger purchases of this sort, the value rising to $\$ 4,554, \infty 00$ per annum. Europe does not, of course, compete seriously in this business. Meat and dairy products $(\$ 332, \infty 00$ per annum), refined sugar $(\$ 44, \infty)$, fruit and nuts $(\$ 35, \infty)$, vegetables $(\$ 9, \infty)$, fish, $(\$ 9, \infty)$, wines, spirits and malt liquors $(\$ 38, \infty)$, and tobacco manufactures $\left(\$_{3}, \infty\right)$ are the only other items of this class in our exports to Japan. Our sales of only two of these are increasing; meat and dairy products and refined sugar. The others are stationary or declining. Wines, spirits, and malt liquors, for example, have dropped from $\$ 221,000$ per annum in $1897-1901$ to $\$ 38,000$ in $1907-$ I9I I and the tobacco trade has fallen from $\$ 300,000$ to $\$ 3, \infty 00$.

England sells Japan fairly large and increasing quantities of condensed milk (\$234,000 per annum) and a few other small items, amounting together to $\$ 39,000$ per annum. Germany sells wines, spirits, malt liquors, and tobacco to the value of $\$ 57, \infty 0$ per annum; sugar and malt make up most of the balance of $\$ 400,000$ per annum. German trade in foodstuffs, has, however, dropped from a total of $\$ 1,900$,$\infty 00$ per annum in $1897-1901$ to $\$ 457,000$ in 1907-rgrr.

\section{B. Clothing and Clothing Materials}

The position of the competitors for this trade can best be shown in tabular form. 
EXPORTS OF CLOTHING AND CLOTHING MATERIALS TO JAPAN

Annual averages in thousands of dollars

\begin{tabular}{|c|c|c|c|c|c|c|c|c|c|}
\hline & \multicolumn{3}{|c|}{ United States } & \multicolumn{3}{|c|}{ UNTTED KINGDOM } & \multicolumn{3}{|c|}{ Germany } \\
\hline & $\begin{array}{c}\text { rst } \\
\text { period }\end{array}$ & $\begin{array}{c}\text { 2nd } \\
\text { period }\end{array}$ & $\underset{\text { period }}{\text { 3rd }}$ & $\begin{array}{c}\text { Ist } \\
\text { period }\end{array}$ & $\begin{array}{c}\text { 2nd } \\
\text { period }\end{array}$ & $\underset{\text { period }}{\text { 3rd }}$ & $\begin{array}{c}\text { rst } \\
\text { period }\end{array}$ & $\begin{array}{c}\text { 2nd } \\
\text { period }\end{array}$ & period \\
\hline Cottons. . & 85 & 418 & 97 & $8,864^{1}$ & $7,056^{1}$ & $8,386^{1}$ & $38 \mathrm{I}^{1}$ & $47^{1}$ & $362^{1}$ \\
\hline Woolens. . . . . . . . & & & & 2,435 & 4,534 & 4,402 & $2,26 \mathrm{I}^{1}$ & $3,046^{1}$ & $2,989^{1}$ \\
\hline Linens. . . . . . . . . & & & & $259^{1}$ & $809^{1}$ & $726^{1}$ & & & \\
\hline Silks... & & & & 230 & 219 & I70 & $\mathbf{I 3 3}$ & 148 & 267 \\
\hline Leather mfs. ${ }^{2} \ldots$ & I6 & 35 & 20 & 56 & 127 & 175 & 48 & I38 & $\mathrm{I} 24$ \\
\hline Apparel........ & & & & 99 & 78 & 54 & 43 & 77 & 52 \\
\hline Haberdashery, etc. & & & & & 58 & 49 & & & \\
\hline Hats....... & & & & II3 & 122 & 224 & & & \\
\hline Cotton Yarn alone & & & & $3,3 \mathbf{I} 2$ & 847 & 463 & & & \\
\hline Leather ${ }^{4} \ldots$ & 335 & $x, 662$ & 982 & & & & & & \\
\hline
\end{tabular}

${ }^{1}$ Includes yarn.

${ }^{2}$ Includes boots and shoes which are not separately stated.

${ }^{3}$ Included in apparel.

${ }^{4}$ Mostly sole leather.

Little comment is necessary. The exports from the United States are almost negligible, the only item of considerable size being leather (mostly sole leather). This business is a rapidly growing one, our exports in 1907 -I9II being nearly three times as large as in $1897-1901$ and averaging now about $\$ 1,000,000$ per annum. The larger figure for the middle period undoubtedly reflects the stimulus of the Russian war.

The chief items in Japan's imports are cottons and woolens, and England and Germany are the two competitors for the trade, the former leading by a large margin. In woolens England leads Germany by nearly 50 per cent. and her trade has increased between I897-I90I and I907-I9II 
by 81 per cent., while Germany's has grown only 32 per cent. In cottons, England almost monopolizes the market, her sales being nearly twenty-three times as large as Germany's. An interesting fact, in view of the development of Japanese cotton mills is the decline of British exports of cotton yarn. These have dropped from $\$ 3,312,000$ per annum for $1897-1901$ to $\$_{4} 63,000$ for $1907-1911$. On the other hand cotton manufactures proper (excluding yarn) show a considerable increase-from $\$ 5,552,000$ per annum to $\$ 7,923, \infty 00$. The figures of raw cotton imports are of interest in this connection. The exports from the United States in $1897-1901$ reached $\$ 6,460,000$ per annum; in I907-I9r I they had risen 69 per cent. to $\$ 10,899,000$. Even more marked is the import into Japan of raw cotton from India. According to Japanese figures the purchases from this source amounted to $\$ 24, \infty \infty, \infty 00$ per annum from 1905 to 1908 , and rose to $\$ 41,700,000$ per annum in 1909-1911. The imports from China have also grown remarkably, from $\$ 9,300,000$ in $1905-1908$ to $\$ 12,000,000$ in $1909-1911$. The total import, according to Japanese figures, now reaches the large figure of $\$ 69, \infty \infty, \infty \infty$ per annum and is increasing rapidly. 


\section{Iron and Steel Manufactures}

EXPORTS OF IRON AND STEEL MANUFACTURES TO JAPAN

Annual averages in thousands of dollars

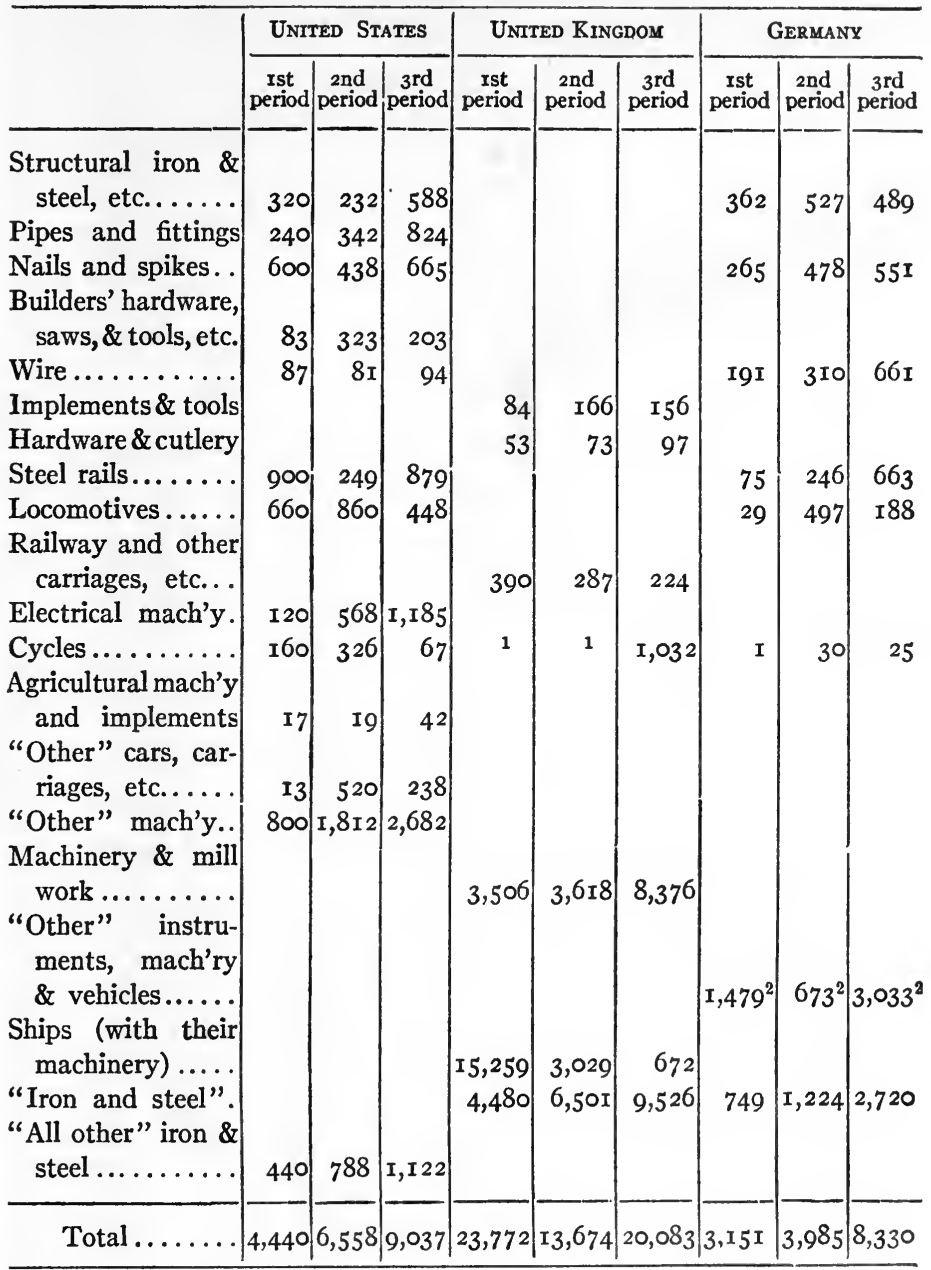

${ }^{1}$ Not separately stated. $\quad{ }^{2}$ The largest items are brewing, metal working, electric, sugar milling, and water power machinery. 
Direct comparisons between the three countries with respect to the separate items are impossible because of the great differences in classification, yet one or two interesting points may be noted. The German classification "Instruments, machinery, and vehicles" includes such items as are separately stated in the American figures under the headings, electrical machinery, agricultural machinery and implements, cars, carriages, etc., and other machinery. The totals for these classes may therefore be compared with the German figures. The total export of these goods from the United States to Japan amounted to $\$ 937,000$ per annum in 1897-1901; to $\$ 2,399,000$ in 1902-1906; and $\$ 3,909,000$ in 1907-1911. German sales for the same three periods respectively were $\$ 1,479, \infty 00, \$ 673, \infty 00$, and $\$ 3,033,000$. So far as this group of goods is concerned, the United States is outstripping Germany. American sales are not only nearly one-third again as large as the German, but the former have increased between 1897-1901 and 1907-r9r1, by 317 per cent., while the latter have grown by only 105 per cent. German exports of locomotives showed a remarkable increase in the middle period but they dropped again in the third, to a position well behind ours. In cycles American sales are still ahead of the German but the latter show a tendency to increase and the former, to decline. The English classification does not permit of direct comparison for this group of goods, for machinery and millwork are stated together and millwork is undoubtedly a large factor. We may however get some impression of relative growth by noting that the three items of British export of this sort, 
cycles, railway and other carriages, and machinery and millwork together show a rapid growth-from $\$ 3,896,000$ per annum in $1897-1901$, to $\$ 9,632,000$ in $1907-1911$, an increase of 147 per cent. How much of this increase is due to millwork it is impossible to say; yet the indications are that machinery export from England is rapidly increasing as in the case of the United States and Germany and that the English figures for machinery alone are probably at least as large as those for the United States.

The items which appear under the headings of structural iron and steel, nails and spikes, wire, and steel rails, reached a total in the American export, in 1897-I90I, of $\$ 1,907,000$ per annum; in 1902-1906, $\$ 1,000,000$; and in 1907-r9II, $\$ 2,226,000$. German sales have increased from $\$ 893,000$ per annum in $1897-1901$ to $\$ 2,364,000$ in $1907-191$. The German increase between the first and third periods was r65 per cent.; the American, only I 7 per cent. In the first period German sales were only 47 per cent. as large as American; in the last period they were 6 per cent. larger than ours. In one only of these four items, structural iron and steel, has the United States made more rapid advance than Germany. In nails and spikes, wire, and steel rails, German progress is far greater than ours. In the British figures these items, as well as pipes and fittings, builders' hardware and tools, and "all other" iron and steel, are all included under the rubrics implements and tools, hardware and cutlery, iron and steel, and machinery and millwork, but here again the impossibility of separating machinery from millwork prevents a comparison of the absolute figures 
and we can only get a rough indication of the rate of growth. The English figures, including these items, are $\$ 8,123, \infty 0$ per annum for 1897-1901; \$10,358,000 for 1902-1906; and $\$ 18,155,000$ for 1907-19Ir; the American, $\$ 2,670, \infty 00$, $\$ 2,45^{2}, 000$, and $\$ 4,375,000$ for the three periods respectively. The British total, therefore, not only greatly exceeds the American, but the growth is also far more rapid.

One more fact deserves note-the decreased sale of ships by England to Japan. From \$1 5,259,000 per annum for the first period, the business has dropped to $\$ 670,000$, a commentary on the growth of Japanese shipyards. 


\section{Miscellaneous Manufactures}

EXPORTS OF MISCELLANEOUS MANUFACTURES TO JAPAN

Annual averages in thousands of dollars

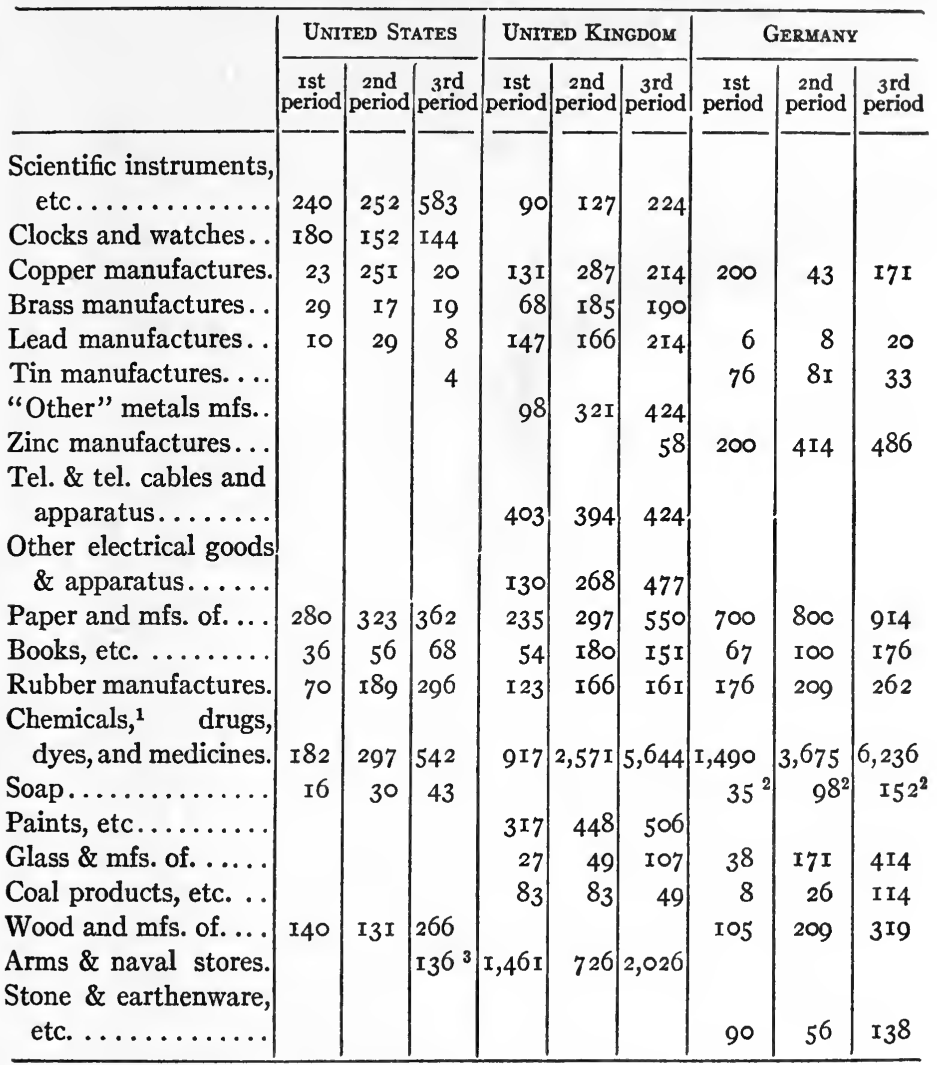

1 Including fertilizers and explosives.

2 Includes also oils, fats, etc.

${ }^{3}$ Naval stores only.

It will be seen that of all these miscellaneous manufactures for which the figures permit of comparisons, the United States leads in only three; scientific instruments and appa- 
ratus, clocks and watches, and rubber goods. In clocks and watches our trade is declining, but in both of the others there is a handsome increase; in scientific instruments from $\$ 240,000$ per annum in $1897-1901$, to $\$ 583,000$ in 1907-1911; and in rubber manufactures, from $\$ 70,000$ to $\$ 296, \infty 00$. Several other items of American trade are, however, also tending to increase in value. Paper and paper manufactures have risen from $\$ 280,000$ per annum to $\$ 362, \infty 00$; books, etc., from $\$ 36, \infty$ o to $\$ 68, \infty$; chemicals, etc., from $\$ 182, \infty 00$ to $\$ 542, \infty \infty$; soap, from $\$ 16, \infty 00$ to $\$ 43, \infty 00$; and wood and woodware, from $\$ 140, \infty 00$ to $\$ 266,000$. Only copper, brass, and lead have declined, but the items are very small. England leads in copper, brass, lead, "other metals," telephone and telegraph cables and appliances, other electrical goods and appliances, paints, and arms; and all are increasing rapidly. In scientific instruments and apparatus, paper, books, rubber, chemicals, etc., and glass, although England does not occupy first place, her sales are also increasing markedly; only in coal products, a small item, has there been a decline. Germany is quite as successful. That country leads in the export of tin, zinc, paper, books, chemicals, etc., soap, etc., glass, coal products, and wood manufactures, and all of these show great increase since $1897-1901$ with the single exception of tin. Another item of German trade that is declining is copper, the German export of which has now fallen below the English. On the whole, in this trade in miscellaneous manufactures, the United States is hardly holding its own, although there is promising growth in some particulars. 


\section{Australasia}

Australasian trade is so nearly monopolized by England and so few items of export from the other Atlantic countries reach figures large enough to be reported separately, that it is especially difficult to make comparisons. Yet there are a few points which may deserve notice as indicating directions in which such rivals of England as the United States and Germany may conceivably compete under improved conditions.

\section{A. Foodstuffs}

EXPORTS OF FOODSTUFF,, ETC. TO AUSTRALASIA

Annual averages in thousands of dollars

\begin{tabular}{|c|c|c|c|c|c|c|}
\hline & \multicolumn{2}{|c|}{ UNITED StaTeS } & \multicolumn{2}{|c|}{ UNITED KINGDOM } & \multicolumn{2}{|c|}{ GERMANY } \\
\hline & $\begin{array}{c}\text { Ist } \\
\text { period }\end{array}$ & $\begin{array}{l}\text { 2nd } \\
\text { period }\end{array}$ & $\begin{array}{c}\text { Ist } \\
\text { period }\end{array}$ & $\begin{array}{c}\text { 2nd } \\
\text { period }\end{array}$ & $\begin{array}{c}\text { rst } \\
\text { period }\end{array}$ & $\begin{array}{l}\text { 2nd } \\
\text { period }\end{array}$ \\
\hline Breadstuffs. . & $\mathbf{I}, 9 \mathbf{I} 3$ & 220 & 453 & 462 & & \\
\hline Fish............ & 520 & 600 & $5 \mathrm{r} 6$ & 649 & & \\
\hline 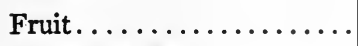 & 280 & 380 & & & & \\
\hline Provisions, etc.......... & 257 & 223 & $6 \mathrm{I}_{4}$ & 579 & & \\
\hline Tobacco, raw........... & 800 & $\mathrm{I}, 700$ & & & & \\
\hline Tobacco manufactures..... & $\mathbf{I}, 540$ & $I, 260$ & 272 & 750 & & \\
\hline Glucose.............. & & 140 & & & & \\
\hline Hops................... & & 80 & & & & \\
\hline 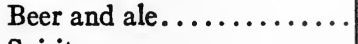 & & & $\mathrm{I}, 4 \mathrm{I} 7$ & $\mathrm{r}, 636$ & & $143^{1}$ \\
\hline Spirits............ & & & 3,570 & 4,384 & & \\
\hline Cocoa, etc............... & & & 385 & 467 & & \\
\hline Condensed milk...... & & & I 26 & 423 & & \\
\hline Pickles, etc............ & & & 779 & 618 & & \\
\hline Salt................ & & & 152 & 170 & & \\
\hline Confectionery, etc........ & & & 740 & $\mathrm{I}, 250$ & & \\
\hline Miscellaneous............ & & & & & 464 & 833 \\
\hline Total. & 5,310 & 4,603 & 9,024 & II, 386 & 464 & 976 \\
\hline
\end{tabular}

${ }^{1}$ Beer and tobacco. 
German export is relatively so small as to be negligible. England and the United States are the real competitors, with the former gaining rapidly, American exports having declined 13 per cent., while English have increased 26 per cent. The largest items of British trade are spirits and beer and ale which together make up more than one-half of the total. In these goods the United States does not compete and is not likely to compete seriously, so we shall get a better comparison of the trade if we omit these two items. With these deductions, British export becomes $\$ 4,037, \infty 0$ and $\$ 5,366, \infty 00$ per annum for the two periods respectively, or about equivalent to the American sales. But even with these omissions English trade is gaining while ours is losing. The loss in American trade is, however, mainly due to one item, breadstuffs, commodities of which Australasia is abundantly able to produce its own supplies. As an article of import it is likely to become less and less important. In regard to the remaining items of export from the United States; fish, fruit, provisions, etc., tobacco and manufactures thereof, glucose, and hops, it may be noted that our trade is gaining, the totals being $\$ 3,397, \infty 00$ and $\$ 4,383,000$ for the respective periods. Significant both of the development of domestic industries in Australia and New Zealand and of the increasing trade of England in more elaborated products are the figures concerning tobacco and tobacco manufactures. Our export of raw tobacco has more than doubled, but our sales of manufactures have declined. England's sales of manufactured tobacco, on the other hand, though small, are gaining. 


\section{B. Clothing and Clothing Materials}

The dominant position of England is shown by the following figures:

EXPORTS TO AUSTRALASIA OF CLOTHING AND CLOTHING MATERIALS

Annual averages in thousands of dollars

\begin{tabular}{|c|c|c|c|c|c|c|}
\hline & \multicolumn{2}{|c|}{ UnTtED States } & \multicolumn{2}{|c|}{ UNITED KINGDOM } & \multicolumn{2}{|c|}{ Germany } \\
\hline & $\begin{array}{c}\text { Ist } \\
\text { period }\end{array}$ & $\begin{array}{c}\text { 2nd } \\
\text { period }\end{array}$ & $\begin{array}{c}\text { rst } \\
\text { period }\end{array}$ & $\begin{array}{l}\text { 2nd } \\
\text { period }\end{array}$ & $\begin{array}{c}\text { rst } \\
\text { period }\end{array}$ & $\begin{array}{l}\text { 2nd } \\
\text { period }\end{array}$ \\
\hline Cottons, colored........ & 360 & 560 & & & & \\
\hline Cottons, uncolored... & 180 & 240 & I 7,900 & 24,050 & $\mathbf{I}, \mathbf{I} \mathbf{I g}$ & $I, 542$ \\
\hline Cottons, other........ & 160 & I8o & & & & \\
\hline Boots and shoes........ & 700 & 280 & & & & \\
\hline Woolens. . . . . . . . . . & & & I0,390 & I4,580 & 604 & 585 \\
\hline Linens.......... & & & 2,455 & $3,2 \mathrm{ro}$ & & \\
\hline Silks.......... & & & 526 & 663 & I3I & 234 \\
\hline Apparel........ & $280^{1}$ & $420^{1}$ & 5,850 & 6,040 & $35^{6}$ & 208 \\
\hline Hats........... & & & $\mathbf{I}, 462$ & $\mathbf{I}, 45^{8}$ & & \\
\hline Haberdashery, etc. . & & & 2,050 & $\mathbf{I}, 438$ & & \\
\hline
\end{tabular}

${ }^{1}$ Cotton apparel only.

The United States cannot be said to have entered the market in woolens, linens, silks, etc., the amount of our export being so insignificant as not to be entered separately in our official statistics. In cottons our trade is also almost negligible, but what little business we have is increasing. Germany occupies almost as insignificant a position as the United States, and her small trade is not increasing quite so fast as ours. England dominates the market and her monopoly seems to be becoming even more complete, for her huge sales are increasing even more rapidly than those of either the United States or Germany. 
The same may be said in regard to woolens, Germany's negligible trade is declining while England's enormous export is increasing rapidly. In silks, on the other hand, Germany though still selling only a little over one-third as much as England, appears to be making promising progress.

Only in cotton clothing does there seem to be any ray of encouragement for American traders. Our sales are insignificant compared with England's, but they are more than double those of Germany and show a promising increase between the two periods. Boots and shoes, in which our trade might be expected to have possibilities of improvement, show an astonishing decline.

\section{Iron and Stecl Manufactures}

The most important class of goods imported by Australia and New Zealand consists of the miscellaneous manufactures of iron and steel. Australia possesses some iron mines and has developed a small protected domestic manufacture, but in the main the supplies needed by the entire population are still and are likely to continue to be purchased from abroad. It is in this trade that the United States, though far behind England, makes the best showing. The details are shown in the following table: 
EXPORTS OF IRON AND STEEL TO BRITISH AUSTRALASIA

Annual averages in thousands of dollars

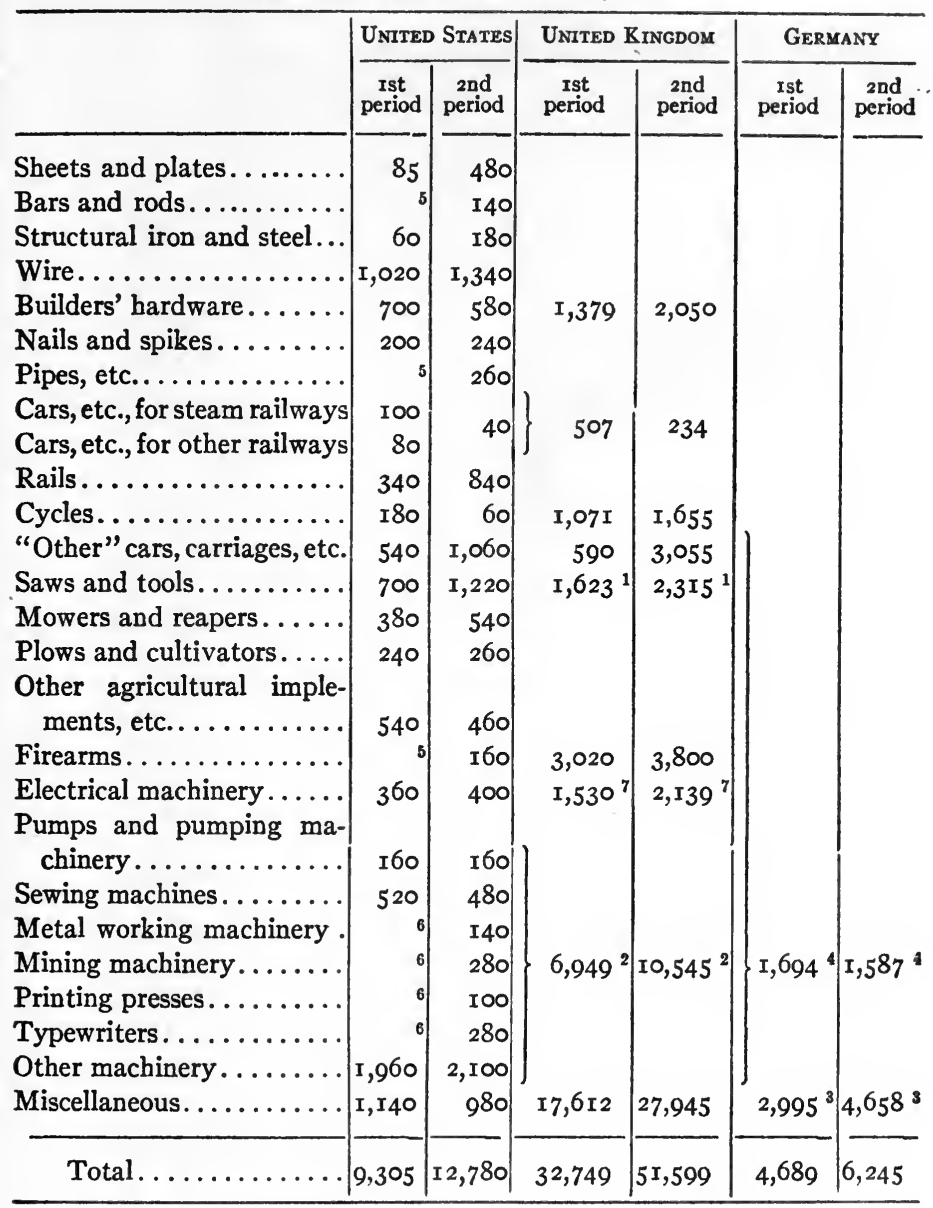

${ }^{1}$ Includes "implements, etc.," and cutlery. ${ }^{2}$ Includes "Steam engines," "agricultural machinery" and "other machinery."

"Includes all except instruments, machines, and vehicles.

"Includes cars, carriages, etc.

${ }^{5}$ Not stated separately.

"Included in "other machinery."

'Includes telephone \& telegraph apparatus \& wire. 
The largest export from the United States is machinery, etc., the annual average for $1902-1906$ being $\$ 5,580,000$ and for I907-I9II $\$ 7,700, \infty 00$, an increase of 38 per cent. German sales in the same time decreased from $\$ 1,694,000$ to $\$ 1,587,000$, or 6 per cent. We are therefore gaining ground compared with Germany. English sales however are not only much larger than ours, $\$ 14,583,000$ and $\$ 23,509,000$ for the respective periods, but their increase is more rapid, 6r per cent. Concerning a few of the specific items in the list of iron and steel goods, direct comparisons with the English figures are possible. In builders' hardware, railway cars, cycles, the United States has increased her sales not only relatively but in absolute amount as well. In cars, carriages, etc. (other than railway cars) American trade has made rapid advance, 96 per cent.; but England's advance has been even greater, $4^{1} 8$ per cent., and her sales are now three times as large as ours. Only in saws and tools do we show a faster growth than England, 74 per cent. to her 43 per cent. Nevertheless, in spite of this unfavorable showing, there are certain items in which, although comparative figures are not available, American trade seems to show some possibilities of development. These are: sheets, plates, bars, rods, and general structural iron and steel; wire, nails and spikes; rails; saws and tools, mowers and reapers, plows and cultivators; electrical, metal-working, and mining machinery; typewriters and printing presses. 


\section{Miscellaneous Manufactures, etc.}

\section{EXPORTS OF MISCELLANEOUS MANUFACTURES TO BRITISH AUSTRALASIA}

Annual averages in thousands of dollars

\begin{tabular}{|c|c|c|c|c|c|c|}
\hline & \multicolumn{2}{|c|}{ Unted States } & \multicolumn{2}{|c|}{ UNITED KINGDOM } & \multicolumn{2}{|c|}{ Germany } \\
\hline & $\begin{array}{c}\text { rst } \\
\text { period }\end{array}$ & $\begin{array}{c}\text { 2nd } \\
\text { period }\end{array}$ & $\begin{array}{c}\text { rst } \\
\text { period }\end{array}$ & $\begin{array}{l}\text { 2nd } \\
\text { period }\end{array}$ & $\begin{array}{c}\text { ist } \\
\text { period }\end{array}$ & $\begin{array}{l}\text { 2nd } \\
\text { period }\end{array}$ \\
\hline $\begin{array}{l}\text { Scientific instruments and ap- } \\
\text { paratus............ }\end{array}$ & 380 & 500 & 361 & 672 & & \\
\hline 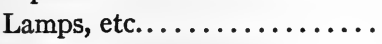 & 180 & 260 & & & & \\
\hline Tin manufactures.......... & 32 & 32 & & & 38 & 53 \\
\hline Copper manufacturers ....... & & 45 & 643 & I,4IO & 248 & 243 \\
\hline Clocks and watches......... & 220 & 300 & & & & \\
\hline Blacking .............. & 100 & 80 & & & & \\
\hline Books, etc. .......... & 220 & 300 & 2,439 & $2,92 I$ & 165 & $5 I$ \\
\hline Printing paper............ & 960 & 300 & & & & \\
\hline Other paper........... & 440 & 460 & 2,332 & 3,572 & 418 & 642 \\
\hline Medicines, etc. . .......... & 300 & 420 & $\mathbf{I}, 292$ & 1,410 & & \\
\hline Explosives.............. & 300 & 280 & & & 917 & 1,230 \\
\hline Other chemicals........... & 460 & 460 & 3,141 & 3,701 & & \\
\hline Glass............... & 200 & 220 & $I, 05^{2}$ & $\mathbf{I}, 258$ & I75 & 391 \\
\hline 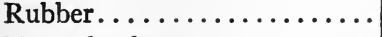 & 260 & 460 & 629 & 785 & I 26 & 85 \\
\hline Upper leather.......... & 660 & 860 & & & 314 & 566 \\
\hline Other leather (ex. boots, etc.).. & 200 & 220 & 2,343 & 3,200 & 314 & \\
\hline Marble and stone mfs........ & 140 & 80 & & & & \\
\hline Musical instruments........ & I 20 & 200 & 375 & 677 & & \\
\hline Spirits of turpentine........ & 240 & 380 & & & & \\
\hline Paints, etc......... & 200 & 360 & 1,525 & 2,222 & & \\
\hline 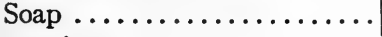 & 180 & I80 & 219 & 282 & & \\
\hline Furniture . . . . . . . . . & 220 & 240 & 316 & $36 r$ & & \\
\hline $\begin{array}{l}\text { Wood manufactures ex. furni- } \\
\text { ture and lumber........... }\end{array}$ & 620 & 700 & 102 & 146 & 373 & 343 \\
\hline Brass manufactures......... & & & $65^{8}$ & $\mathrm{I}, 24 \mathrm{I}$ & & \\
\hline "Other metals;" mfs. of..... & & & 239 & 414 & & \\
\hline Plate and plated ware....... & & & $1, \infty 00$ & $\mathbf{I}, 665$ & & \\
\hline Stationery other than paper.. & & & 1,032 & 1,286 & & \\
\hline Chinaware, etc........... & & & $I, 268$ & 1,720 & $43 I$ & 472 \\
\hline Oil cloth. . & & & $\mathrm{I}, 820$ & 2,725 & & \\
\hline Brooms, etc. ......... & & & 68 & 93 & I06 & 89 \\
\hline
\end{tabular}


The United States leads in the sale of turpentine, wooden furniture, and manufactures of wood other than furniture and lumber. The turpentine business is relatively small, $\$ 380,000$ per annum, but the sales of furniture and other manufactures of wood reach the considerable value of nearly $\$ 1, \infty \infty, \infty \infty$ per annum. In this latter class of goods, however, England is gaining more rapidly than the United States. German business is declining. For all the other items for which the figures permit of comparison, England leads the United States, in most cases by a large margin. German sales exceed those of the United States for four items, copper manufactures, medicines, drugs and chemicals, glass and tin manufactures, but only by small amounts. In no case do German sales equal the English. American sales have been increasing in scientific instruments, etc., lamps, etc., clocks and watches, books, etc., medicines, glass, rubber, musical instruments, turpentine, paints, etc., furniture and wood manufactures; and in several cases in which comparisons are possible, American trade has grown more rapidly than that of either Germany or England. In books, for example, our export has increased 37 per cent., and England's, only 20 per cent., while Germany's has decreased by 70 per cent. In medicines, American trade has increased 40 per cent., and England's less than ro per cent. In rubber manufactures ours has expanded by 77 per cent. ; and England's, by only 25 per cent. Germany's has declined 33 per cent. Our export of paints, etc., has grown 80 per cent., and England's only 46 per cent. There are certain indications, therefore, that in spite of England's 
dominating hold on the market, the United States is able to compete in a considerable number of commodities.

\section{The Philippine Islands}

The United States occupies a position in the Philippine market somewhat similar to that of England in Australia and New Zealand. Since the annexation of the islands, not only has the trade enormously increased but the bulk of it, which was formerly in the hands of England and Spain, has passed into American control and our share while not yet so great as that of England in Australasia is rapidly approaching a quasi monopoly.

$$
\text { A. Foodstuffs, etc. }
$$

EXPORTS OF FOODSTUFFS, ETC., TO THE PHILIPPINE ISLANDS Annual averages in thousands of dollars

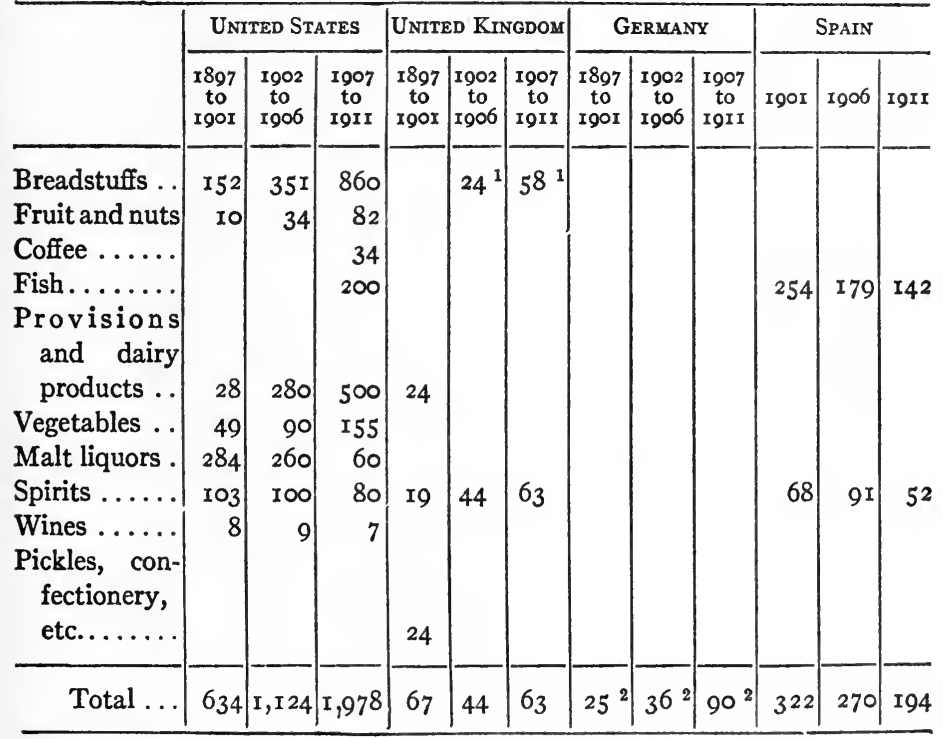

1 Biscuit, etc.

${ }^{2}$ Nearly all wines and liquors. 
The trade is small at best. It was divided chiefly between the United States and Spain prior to annexation but has now passed almost wholly into the hands of the former. The largest single item is breadstuffs, but provisions and dairy products, fish, vegetables, and fruit and nuts are moderately important.

The islands being so largely agricultural, the bulk of the food of the people is of course produced at home and the business in foodstuffs is not likely to reach very large dimensions.

\section{B. Clothing and Clothing Materials}

EXPORTS OF CLOTHING, ETC., TO THE PHILIPPINE ISLANDS

Annual averages in thousands of dollars

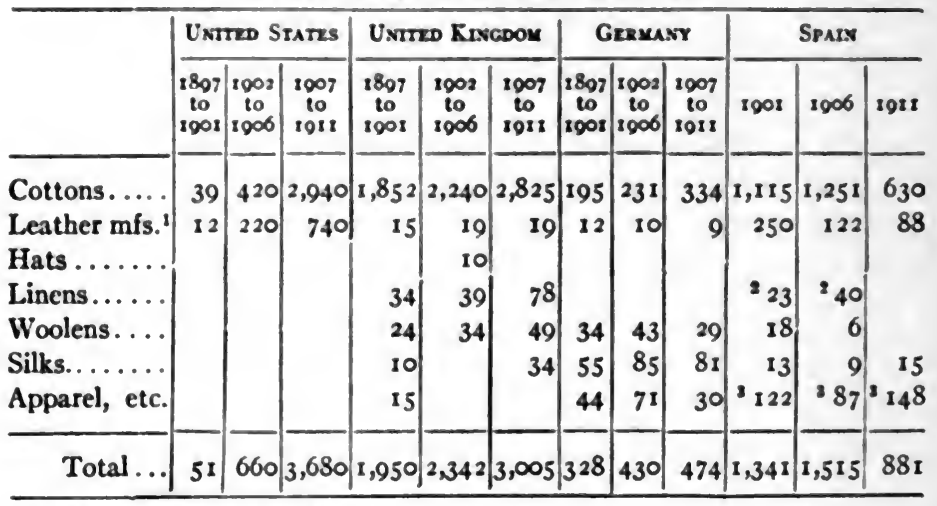

1 Mostly boots and shoes.

2 Includes cordage.

3 Includes hats, etc.

The imports of cottons and of boots and shoes overshadow all other items in this general class. The great change which has taken place in the position of the United States is 
clearly shown in the table. In cottons our export which in I897-I90I was only one-fiftieth as large as England's, one-thirtieth of Spain's, and one-fifth of Germany's, is now slightly larger than England's; nearly five times as large as Spain's; and nearly tenfold that of Germany. Our boot and shoe export which in 1897-rgor was less than onetwentieth that of Spain is now nine times as great as hers. Germany still maintains a lead in silks, but the amount is small.

\section{Iron and Steel Manufactures}

EXPORTS OF IRON AND STEEL MANUFACTURES TO THE PHILIPPINE ISLANDS

Annual averages in thousands of dollars

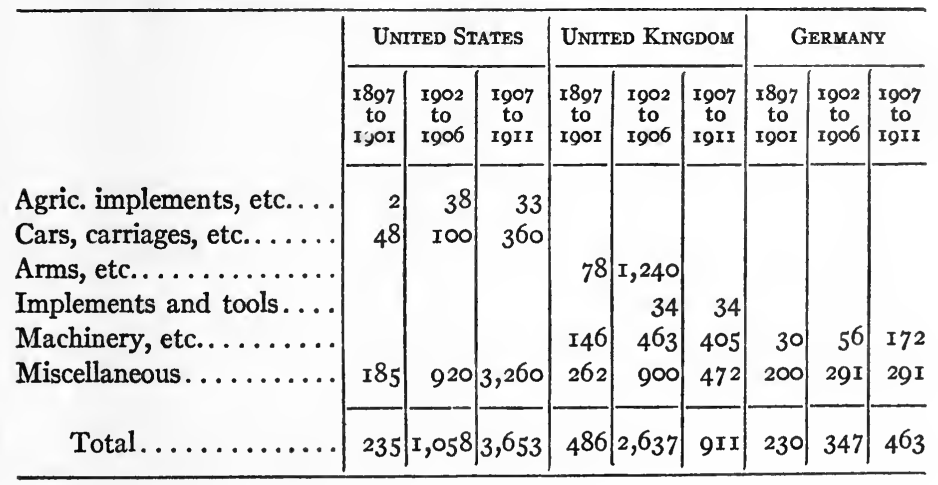

The classification is too incomplete to permit the making of any useful comparisons. The astonishing advance of the United States is, however, clearly emphasized. 


\section{Miscellaneous Manufactures}

EXPORTS OF MISCELLANEOUS MANUFACTURES TO THE PHILIPPINE ISLANDS

Annual averages in thousands of dollars

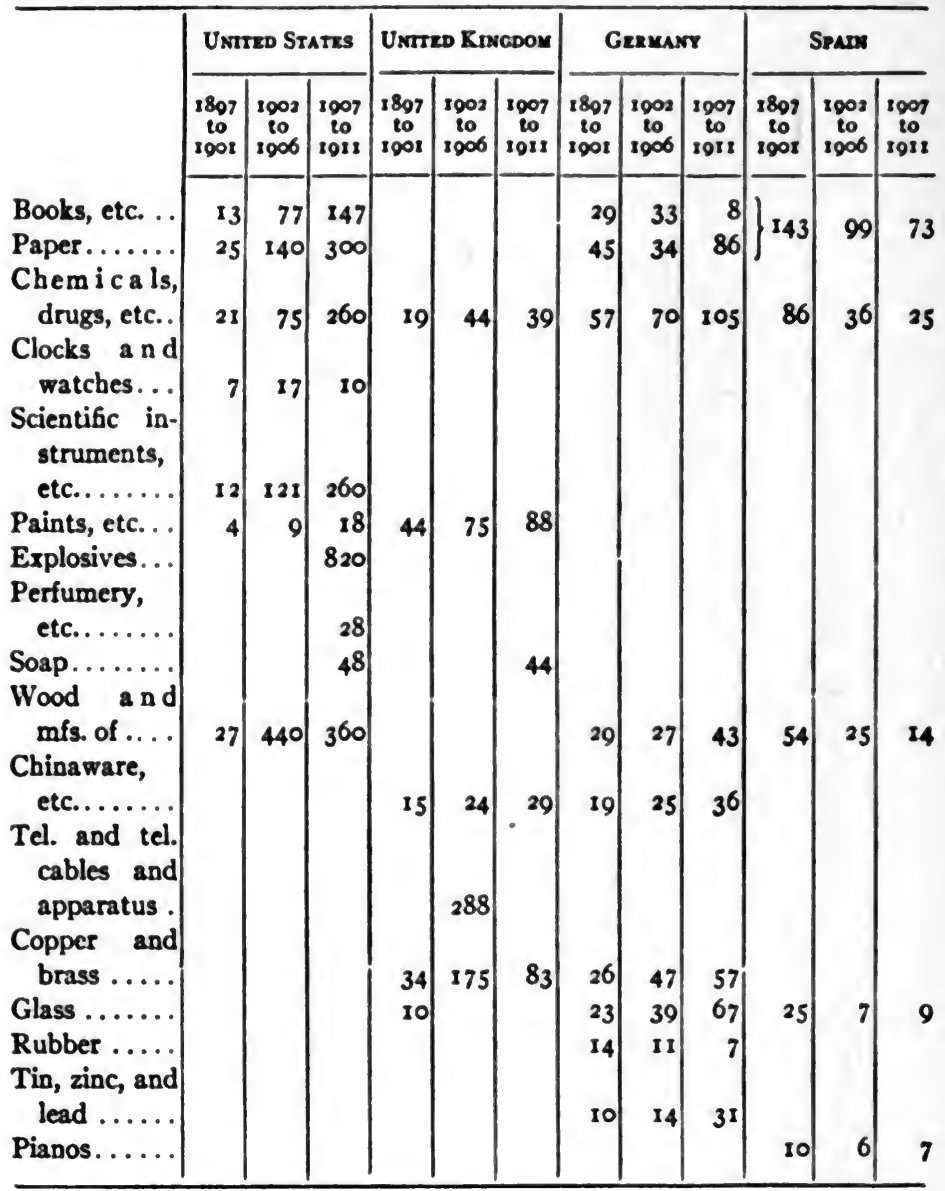


These figures fully bear out the statement already made that since the annexation of the islands by the United States, their trade has tended to drift rapidly into American hands. In every item which is stated separately in the American statistics there has been a marked increase and in all but one, paints, etc., American sales are now larger than those of any of our competitors. Spanish trade has greatly declined in all items, while German has increased in all except books and rubber, but in general not nearly so rapidly as the American. England appears to have made great gains in the earlier years of American occupation (I902-IgO6) but to have suffered a rapid decline since then in all items except paints and chinaware. An interesting feature brought out by the table is the fact that in a considerable number of commodities which the islands purchase from England and Spain, the United States has not yet begun seriously to compete. They are chinaware, copper and brass wares, glass, rubber, tin, zinc, lead, and pianos. The amounts in general are small; yet it might well be worth the while of American merchants to expand their market in these lines.

It is extremely difficult, on the basis of such a mass of details as has been presented in the preceding pages to make any general statement of conclusions. One or two points, however, do seem clear, the most important of which is that the United States is already, in spite of inferior trading facilities, a serious competitor of Europe in many sorts of machinery and in a fair number of miscellaneous manufactures which are in rapidly increasing demand 
in the Pacific countries. It will almost certainly be along lines in which we are already making a good showing that the first and most important results of the opening of the Panama Canal will be felt. Another point which seems clear is that, on the whole, our greatest success is in connection not with the finer, costlier grades or classes of goods, but with the cheaper and coarser sorts calling for large cargo space relatively to value and hence, in general, being rather more suitable for transportation in "tramps" carrying full cargo than the goods sold to the Pacific countries by our European competitors. For traffic of this sort, the possibility of obtaining cargoes is of particular importance and calls for an analysis of the kinds of commodities which the Pacific countries are now sending us and are likely to be able to continue to send us in exchange for these things which they purchase from us. Such an analysis is presented in the next chapter. 


\section{CHAPTER VIII}

\section{DETAILS OF IMPORTS FROM THE PACIFIC COUNTRIES}

As has just been pointed out, a critical examination of imports from the Pacific countries is quite as necessary to a solution of the commercial problem of the Panama Canal as an analysis of the exports to them. This is chiefly due to the intimate dependence of the development of shipping facilities upon the possibility of obtaining adequate return cargoes. But there is also another way in which the question of imports is of great economic significance. International trade consists, in the main, of a barter of goods. A country which exports accepts its pay in the form of imports and in the long run there must be an equivalence of the two. This, of course, does not mean that an exact balance between any two specific countries is likely to be maintained, for the bulk of international dealings is roundabout and indirect, an exporting country often getting its payment in the form of imports from some entirely different portion of the globe from that to which it sells its goods. Yet in the long run the countries of the Pacific must have a dollar's worth of some commodity to sell somewhere in order to pay for each dollar's worth of goods which they purchase anywhere. From the point of view of mere ability to purchase it makes little if any difference where 
they sell their goods: the really important question is whether they have a surplus of goods to sell and whether they are able to find a market for them.

If this were the only question with which we were concerned the examination which has already been presented in Chapter $\mathrm{V}$ of the total figures of the export from the Pacific countries and the general trend of the development there, would be all that is needed. But the direction of export trade is also significant and calls for further analysis. Trade flourishes on mutual understanding of methods and commercial customs, mutual knowledge of the character and qualities of the traders' goods, mutual facilities for exchange, etc., and on the whole, a country is more likely to import things which it needs from a country to which it sells many things than from one with which it otherwise has few dealings. The facilities for movement of goods in one direction are likely to foster a movement in the other. A coffee planter in Central America, for example, who ships his crops to New York is more apt, other things being equal, to make inquiries concerning the purchase of new machinery equipment when he needs it, of his New York connections, than one who markets his product in Hamburg.

It is of some importance, therefore, in a complete analysis of the trade relations of the Atlantic and the Pacific, to give as critical attention to the Atlantic destination of the exports from the Pacific as to the origin of the Pacific purchase of Atlantic goods. The object of the present chapter is to give such an analysis. 


\section{Central America and Colombia}

\section{IMPORTS FROM CENTRAL AMERICA AND COLOMBIA} (items over $\$ 100,000$ only)

Annual averages in millions of dollars

\begin{tabular}{|c|c|c|c|c|c|c|}
\hline & \multicolumn{2}{|c|}{ UnIted States } & \multicolumn{2}{|c|}{ UNITED KINGDOM } & \multicolumn{2}{|c|}{ Germany } \\
\hline & I902-06 & $1907-I I$ & $1902-06$ & $1907-11$ & $1902-06$ & $1907-11$ \\
\hline Cacao .............. & 0.1 & 0.1 & 0.1 & 0.1 & & \\
\hline Coffee...$\ldots \ldots \ldots$ & 8.6 & 9.2 & $4 \cdot I$ & $5 \cdot I$ & $7 \cdot 4$ & $7 \cdot 7$ \\
\hline Bananas . . . . . . . . . & I. 8 & 2.8 & I. 6 & $4 \cdot 2$ & & \\
\hline Fruit, etc. ......... & 2.5 & 2.8 & & & 0.3 & I.O \\
\hline Sugar..$\ldots \ldots \ldots \ldots$ & 0.1 & 0.1 & $0 . \mathrm{r}$ & 0.1 & & \\
\hline Rubber $\ldots \ldots \ldots \ldots \ldots$ & 0.9 & I.O & 0.2 & 0.2 & 0.2 & 0.3 \\
\hline Vegetable ivory ...... & 0.1 & 0.2 & & & & \\
\hline 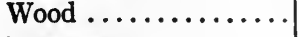 & 0.6 & 0.4 & & & 0.4 & 0.7 \\
\hline Dyes, etc........... & 0.1 & 0.1 & $0.2^{1}$ & 0.1 & & \\
\hline Drugs, etc.......... & & & & & 0.2 & \\
\hline Gold and silver $\ldots \ldots$ & $2 \cdot 7$ & $5 \cdot 4$ & 2.4 & 2.1 & 0.1 & \\
\hline Precious stones, etc.... & & & & 0.1 & 0.1 & \\
\hline Hides..$\ldots \ldots \ldots \ldots$ & I. 6 & I. 2 & 0.2 & 0.2 & 0.4 & 1.0 \\
\hline Hats...$\ldots \ldots \ldots$ & 0.1 & 0.4 & & 0.2 & & $0 . I^{2}$ \\
\hline
\end{tabular}

${ }^{1}$ Mostly indigo.

2 Includes clothing and other ornaments.

The five chief imports into the United States and Europe from these countries are coffee, precious metals, bananas and other fruit, hides, and rubber. They are shipped chiefly to the United States, England, and Germany, the first named being the largest purchaser. We import 80 per cent. more of Central American and Colombian coffee than England, and 20 per cent. more than Germany. Of bananas and other fruit our purchases are 35 per cent. larger than England's and six times as large as Germany's. The largest amounts of the precious metals come to us and our pur- 
chases of hides are five times as large as England's and about io per cent. greater than Germany's.

A notable change, however, is in progress in regard to three of these chief commodities, bananas and fruit, hides, and coffee, particularly the first two:-German and English imports are increasing much more rapidly than ours. In 1902-1906, for example, our purchase of hides was nearly four times as large as Germany's; in 1907-19II ours had declined 25 per cent. while Germany's had risen two-andone-half fold and was a close second to ours. The United States and England share most of the banana and fruit trade but while ours increased between 1902-1906 and 1907-19II from $\$ 4,346, \infty 00$ per annum, to $\$ 5,640, \infty 00$ or 30 per cent., England's rose from $\$ 1,569,000$ to $\$ 4,160,000$ or 165 per cent. Our coffee purchase between the same two periods rose from $\$ 8,628, \infty 00$ per annum to $\$ 9,189, \infty 00$ or about 6 per cent.; but England's increased from $\$ 4,080,000$ to $\$ 5,145, \infty 00,26$ per cent. German import however, increased only 4 per cent. A similar tendency, though less marked, is shown in the rubber trade. American purchases have increased 16 per cent., English, 4 per cent., while the German, though relatively small, have risen 57 per cent.

The cause of this increase in English and German purchases is unquestionably the closer steamship connection established during the past few years through the agency of the Royal Mail Steam Packet Co. and the Hamburg American Steamship Co. Regular and fairly frequent service from Southampton and Hamburg to the Central American 
and Colombian ports has given greater facilities for the European sale of their products.

Among the minor items of Central American and Colombian export, two or three are of some especial interest. Woods, etc., go mainly to the United States and Germany with our purchases declining (from $\$ 665,000$ to $\$ 596,000$ ) and the German increasing (from $\$ 431,000$ to $\$ 655,000$ ). These figures, however, include vegetable ivory and cabinet woods. The purchases of the former, by both the United States and Germany, are increasing rapidly, while those of the latter are declining. Another item of increasing importance is hats (chiefly of the sort known as "Panama") the sales of which to both England and the United States are growing with astonishing rapidity. These two countries alone in the second period purchased to the value of $\$ 679,000$ per annum, an increase of nearly fivefold over the period r902-1906.

It seems clear that in spite of the strong hold which the United States has on these markets, a movement is now going on which is not altogether favorable to the United States. Through increased exports to England and Germany a certain closer business connection is being built up with our commercial rivals. 


\section{MEXICO}

IMPORTS FROM MEXICO

(items over $\$ 1 \infty, \infty 00$ only)

Annual averages in millions of dollars

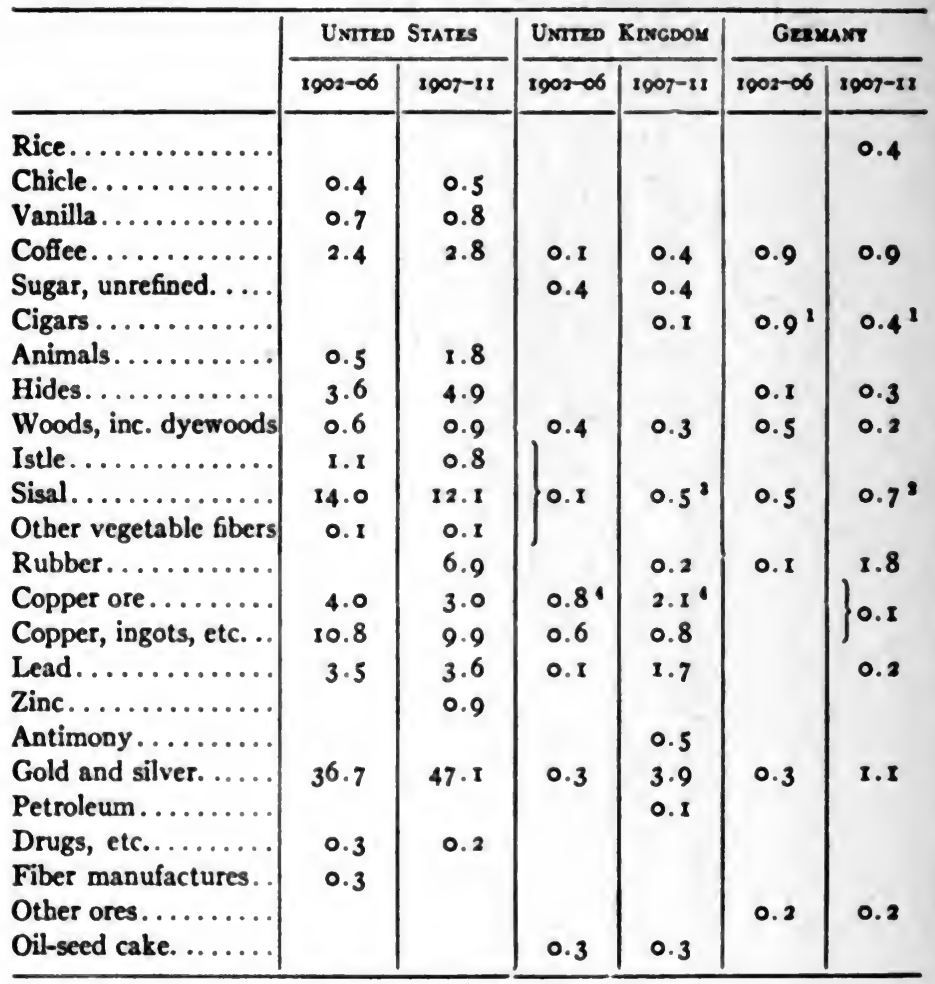

1 Tobacco.

2 Includes Cotton, 0.x.

- Includes Cotton, 0.2.

- Regulus, etc.

The chief exports of Mexico are, of course, minerals, but several other items rise to very considerable importance, 
such as fibers, hides and animals, rubber, and coffee. By far the larger part of these is purchased by the United States. Of the gold, the United States takes practically all, and of the silver about six times as much as England and Germany combined. Germany takes but a small quantity of any of the minerals, but England's share is fairly large and several items, copper, lead, and silver, show an astonishing increase between the two periods, 1902-1906 and I907-I9II. This increase, however, is probably more apparent than real, for the reason that during the second period direct steamship connections were established which had not previously existed and that Mexican minerals which before had gone to England via the United States, now went direct instead. In regard to fibers, the chief of which is sisal, it will be noticed also that neither Germany nor England takes any considerable quantity, the United States being almost the sole market. The same is true of live animals and hides, American purchases of which are not only large but increasing $(\$ 4,240,000$ per annum in I902-I906 and \$6,680,000 in I907-I9II). In coffee, German and English competition is more noticeable, yet together they purchase less than half the amount that we do. English purchases in the second period, however, show a very marked increase (from $\$ 78,000$ to $\$ 409,000$ per annum) probably because of the improved direct steamship connections mentioned above. In the rapidly increasing rubber business Germany is making rapid strides, yet her purchases are only one-fourth of ours.

Minor items are rice, which goes almost wholly to Ger- 
many; chicle, vanilla, and drugs which go to the United States; wood, (including dyewoods), of which the United States takes nearly twice as much as England and Germany together and in which we are increasing our purchases while the English and German are declining; sugar $(\$ 370, \infty)$ which goes almost wholly to England though in decreasing quantities; and oil-seed cake which likewise goes wholly to England.

On the whole, the American hold on the market for Mexican goods is almost complete and there seems to be no reason to expect any change in the situation except possibly in regard to a few specific items. 


\section{The West Coast of South America}

IMPORTS FROM THE WEST COAST OF SOUTH AMERICA (items of $\$ 100,000$ and over only)

Annual averages in millions of dollars

\begin{tabular}{|c|c|c|c|c|c|c|}
\hline & \multicolumn{2}{|c|}{ United States } & \multicolumn{2}{|c|}{ UNITED KINGDOM } & \multicolumn{2}{|c|}{ Germany } \\
\hline & $1902-06$ & I907-II & $1902-06$ & $1907-\mathrm{II}$ & $1902-06$ & $1907-I I$ \\
\hline Nitrate.......... & 9.0 & I4. I & 5.1 & $5 \cdot 7$ & 22.2 & 30.9 \\
\hline Guano............ & 0.1 & 0.2 & 0.5 & 0.5 & 0.5 & 0.9 \\
\hline Other fertilizers.... & & & & & & \\
\hline $\begin{array}{c}\text { Other chemicals and } \\
\text { drugs } \ldots \ldots \ldots\end{array}$ & I.I & 0.8 & 1.0 & I.I & I.9 & 2.5 \\
\hline Fruits and nuts..... & 0.1 & 0.1 & & & & \\
\hline Vegetable ivory.... & 0.2 & 0.3 & & O.I & 0.4 & 0.5 \\
\hline Rubber........... & 0.5 & 0.9 & 2.0 & $4 \cdot I$ & 0.7 & I. 7 \\
\hline Cacao............. & I. 2 & I. 5 & 0.6 & I. 6 & I.9 & I. 5 \\
\hline Coffee............ & 0.1 & 0.1 & 0.1 & 0.1 & 0.1 & ... \\
\hline Sugar............. & I. 2 & 0.4 & I.8 & 2.1 & & \\
\hline Cereals........... & & & I. 6 & $3 \cdot 4$ & 0.3 & 0.5 \\
\hline Honey............ & & & & & 0.1 & 0.1 \\
\hline Meat............. & & & O.I & 0.8 & & \\
\hline Other foodstuffs.... & & & & & $\cdots$ & 2.9 \\
\hline Cotton........... & 0.5 & 0.8 & I. 6 & $3 \cdot 4$ & $\cdots$ & 0.2 \\
\hline Wool.......... & 0.3 & 0.3 & $4 \cdot I$ & $5 \cdot 5$ & 0.2 & 0.9 \\
\hline Fur and fur skins. . & 0.2 & 0.1 & 06 & 00 & & \\
\hline Hides and skins.... & 0.6 & 0.4 & & 0.9 & 0.3 & 0.4 \\
\hline Horns, etc........ & & & & & 0.1 & $\cdots$ \\
\hline Leather.......... & & & & & 0.7 & 0.9 \\
\hline Copper...... & 0.8 & 6.8 & 8.6 & 8.1 & 0.5 & 0.4 \\
\hline Lead......... & 0.1 & $0 . I$ & 0.1 & 0.1 & & \\
\hline Gold and silver. ... & 0.8 & 2.8 & 2.4 & 2.3 & $3 \cdot 5$ & 0.4 \\
\hline Tin $\ldots . . . .$. & & & $4 \cdot 9$ & $7 \cdot 5$ & $\mathrm{I} \cdot 3$ & $5 \cdot 0$ \\
\hline Other metals \& ores & & & 0.1 & 0.3 & 0.5 & I. 2 \\
\hline 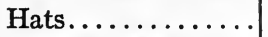 & 0.3 & 0.3 & 0.1 & 0.8 & $\ldots$ & 0.4 \\
\hline Fish oil and shells. . & & & $\ldots$ & 0.2 & & \\
\hline Wax........... & & & $\cdots$ & 0.1 & & \\
\hline Seeds and seed cake & & & 0.7 & 0.8 & & \\
\hline Clays, etc........ & & & & & 0.1 & 0.4 \\
\hline
\end{tabular}


Turning from Mexico and the Central American States to the countries on the west coast of South America, we find at once not only a greater variety of export products to Europe and the United States but also a great difference in respect to the destination of these exports. Mineral products still predominate, but the greater part of them are purchased not by the United States but by Europe. Of only three of these mineral products, nitrate, copper, and silver, does the United States take any large quantities and even in these we are surpassed by Germany or England or both. The largest single item of minerals is nitrate (almost wholly from Chile). Germany in 1907-19r1 purchased to the value of $\$ 30,000, \infty 00$ per annum. The United States took less than one-half as much $(\$ 14,060, \infty \infty)$ and England less than one-fifth as much $\left(\$ 5,66_{5}, \infty\right)$. An interesting fact because of its relation to the question of getting cargoes from the west coast, is the rapid increase of American purchases of this article. Between 1902-1906 and 190719II American purchases increased from $\$ 9,000,000$ to $\$ 14,060, \infty 00$, or 56 per cent., while England's rose only ro per cent. and Germany's 39 per cent. Our relative increase is probably due to the fact that our population has now reached a degree of density which is making more intensive methods of cultivating and fertilizing in agriculture necessary.

Next to nitrate, copper is the most important mineral purchased from these west coast countries. England takes the largest share of this $(\$ 8,125, \infty 00$ per annum), but a remarkable change is making itself felt, for the United States is rapidly becoming a serious competitor. England's 
purchases have actually declined both relatively and absolutely, having fallen $\$ 505,000$ or 6 per cent. between the periods I902-I906 and I907-I9II; ours meantime having jumped nearly ninefold, from $\$ 783,000$ per annum in 1902-r906 to $\$ 6,760,000$ in r907-r9II: they are now not far behind England's. Germany's purchases are insignificant and are declining. As in the case of nitrate, this development in American trade is particularly significant in connection with the question of return cargoes.

The important trade in tin is one in which the United States as yet plays so small a part that the imports from the west coast countries are not entered separately in our published trade statistics. England and Germany take nearly all of the output of about $\$ 13,000,000$ worth. A noteworthy feature is the rapid development of Germany's purchases. In 1902-I906 Germany took not much over one-fourth as much as England ( $\$ 1,305,000$ per annum and $\$ 4,960,000$ respectively). In I907-I9II, in spite of the growth of England's purchases, to $\$ 7,520,000$ per annum, German import had advanced with such phenomenal strides (nearly fourfold) that her purchases reached a value two-thirds as large as England's.

Of the precious metals, silver is of course the most important product of the west coast countries. The United States and England share most of it between them, with the former increasing and the latter declining. Germany's purchases have declined by about 90 per cent. between the two periods, and are now unimportant. The smaller gold output goes chiefly to the United States. 
Other metals and ores including manganese, lead, etc., are taken mainly by Germany and England with the former increasingly in the lead but the total value is small compared with the items already considered.

After mineral products, certain foodstuffs are the next most important export of the west coast countries, the principal items being cereals (mostly from Chile), sugar (from Peru), cacao (from Ecuador), and fruit, nuts, coffee, honey, meat, etc. England takes practically all the cereals $(\$ 3,360,000$ per annum in 1907-1911), and a large share of the sugar $(\$ 2,105, \infty)$ and cacao $(\$ 1,604, \infty)$. The large item of "other foodstuffs" imported into Germany is probably made up mostly of meat and meat products from the German settlements in southern Chile. The United States takes a large share of the cacao $(\$ 1,485,000$ per annum, compared to England's $\$ 1,604,000$ and Germany's $\$ 1,512, \infty 0)$. Germany's purchases of cacao which in 19021906 were by far the largest have materially declined; ours are growing (25 per cent. increase between the two periods) but England's have advanced phenomenally, and now stand in the first place. In the earlier period the United States took considerable quantities of sugar but our purchases have now declined (probably as a result of the rapid development of Cuban sugar production) to such an extent that our imports are only about one-fifth as large as England's.

Of the forest products, the most important are rubber and vegetable ivory. Of the former, England purchases by far the larger part (about 50 per cent. more than Germany and the United States together); and of the latter, Germany 
(considerable more than the United States and England together). Our imports of vegetable ivory are growing rapidly (about 7o per cent. between the two periods) and bid fair soon to pass Germany's, but in rubber both England and Germany are strengthening their hold on the market, the latter country somewhat the more rapidly although her purchases are still only about 40 per cent. as large as England's.

Two other large items, cotton and wool, deserve especial mention. As might be expected, England takes the bulk of the export (of cotton more than three times, and of wool, more than four times as much as Germany and the United States together). The business is increasing rapidly. England's import of cotton increased more than two fold between I902-I906 and I907-I9II, reaching in the latter period an annual value of $\$ 3,37 \mathrm{I}, 000$; and of wool, about 30 per cent., with a total in the second period of $\$ 5,460,000$ per annum. Both of these commodities come chiefly from Peru and furnish an important "return cargo."

It will be noticed in regard to all of these more important exports from the west coast of South America except the precious metals, that they are articles of relatively large bulk and small value. The aggregate value of these articles, excepting gold and silver, imported into the United States from the South American countries averaged \$13,937,000 per annum in I902-1906. In I907-I9II the total rose to $\$ 25,253,000$ per annum, an increase of 82 per cent. Germany's imports of the same items rose in the same time from $\$ 27,744,000$ to $\$ 44,702,000$ per annum, or 6 I per cent.; 
and England's, from $\$ 30,630,000$ to $\$ 42,358,000$ or 38 per cent. If these figures of relative values may be taken as a rough measure of relative quantities as well, the important conclusion would seem to be justified that the development of the trade is tending to strengthen the position of the United States in the matter of return cargoes. It has long been recognized that one of the most serious handicaps under which American exporters to the west coast of South America have labored for many years, has been the inability of vessels delivering goods from our Atlantic seaboard to get remunerative freights for the return trip. Any development which promises relief from this situation must be regarded as one of great significance. 


\section{China}

\section{IMPORTS FROM CHINA}

(items of $\$ 100,000$ and over only)

Annual averages in millions of dollars

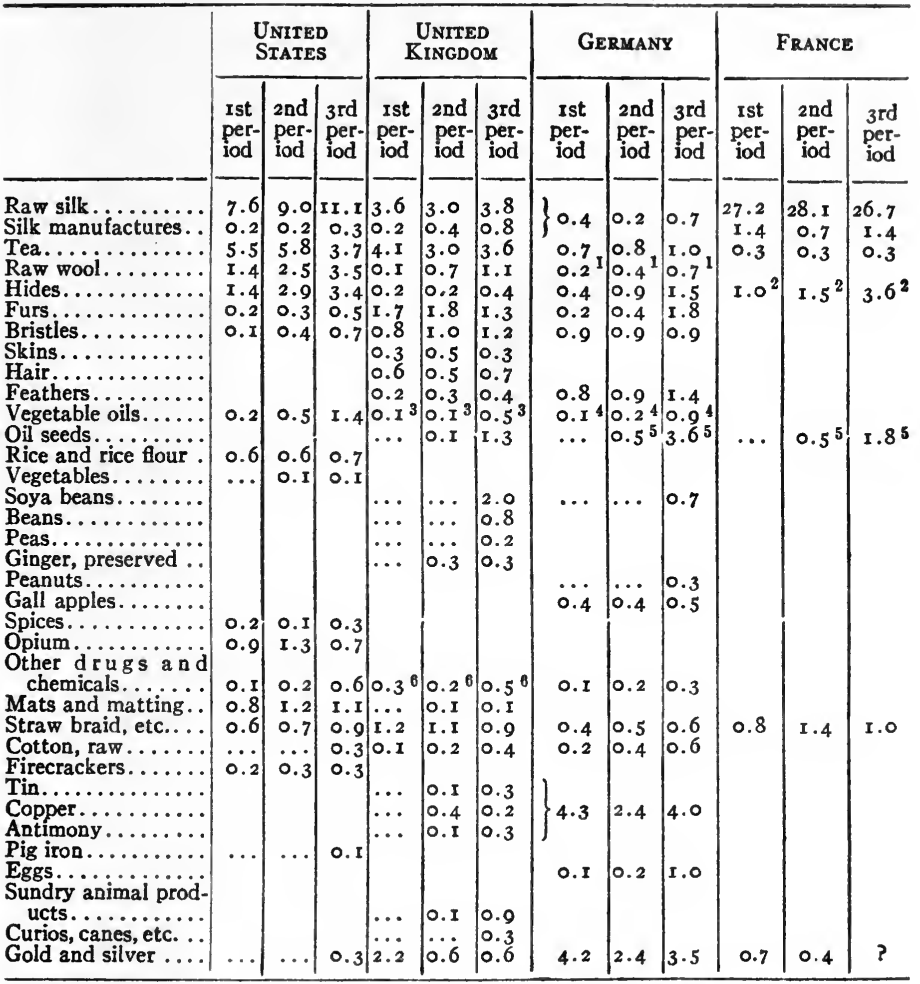

1 Sheep pelts.

2 Includes leather also.

3 All oils.
4 Fats and oils, including ethereal oils.

5 Sesame seeds.

6 All drugs and chemicals.

The largest single item of China's export to Europe and America, silk, is one of relatively high value to small bulk. Several other items also fall into the same class: tea, spices, drugs, etc. The more bulky commodities, more suitable to fill space in return cargoes, include among many other 
things such items as wool, hides, furs, hair, skins, and bristles; oils, rice, and pulse; mats, matting, and braid; and sundry minerals such as tin, antimony, and iron.

The imports of the first class of commodities into the United States in $1897-1901$ averaged $\$ 14,560,000$ per annum; 1907-I9II showed a moderate increase of 14 per cent., to $\$_{16,740, \infty}$ per annum. England's imports of the same kind grew meantime from $\$ 8,279,000$ to $\$ 9,107, \infty 00$, or 10 per cent.; Germany's from $\$ 1,556, \infty 00$ to $\$ 2,489, \infty 00$, or 60 per cent.; France's declined slightly from $\$ 28,950,000$ to $\$ 28,390,000$.

American imports of the second or bulky class averaged $\$ 5,600,000$ per annum in $1897-1901$, and $\$ 13,056,000$ in 1906-1911; the English, $\$ 5,381, \infty 00$ and $\$ 13,435,000$ for the two periods respectively; the German, $\$ 7,463, \infty 00$ and $\$ 17,998, \infty 00$; and the French, $\$ 1,911, \infty 00$ and $\$ 6,485, \infty 00$. The increase in American imports was therefore 133 per cent.; English, 149 per cent.; German, 141 per cent.; and French, 239 per cent. Thus although American imports of this sort have increased enormously, our position in respect to return cargoes would appear to be somewhat less favorable relatively than fifteen years ago.

In spite of this rather unfavorable comparison, however, there are certain indications that the United States may be on the way towards the development of a satisfactory return cargo trade. The chief items in China's export of bulky cheap commodities are, as already stated, wool, hides and skins, furs, bristles, vegetable oils, oil seeds, mats and matting, straw braid, and ores; and in many of these chief 
items, American imports are showing more marked advance than those of her chief European rivals. For example, we are already the chief importers of wool, vegetable oils (chiefly "wood oil"), and mats and matting, and stand close to the top in hides (in which we are slightly surpassed by France), and straw braid (in which we are on a practical equality with England and not far behind France). Our imports of wool have grown from a value of $\$ 1,420,000$ per annum in $1897-1901$ to $\$ 3,460,000$ in $1907-1911$ and are three times as large as those of our nearest competitor, England, and more than five times as large as Germany's. In vegetable oils our imports have increased nearly seven fold since r897-r9or and are larger than England's and Germany's combined. Our imports of bristles have increased more than seven fold, while England's, though still somewhat larger than ours, have grown but fifty per cent., and Germany's have remained stationary.

The chief mineral exports of China are tin, copper, and antimony, the last named being far in the lead. The tin and copper go mostly to England and the antimony almost entirely to Germany, which holds certain concessions in connection with the great deposits in the Yangtsze Valley. Pig iron is also beginning to appear as a considerable export from China but under recent contracts most of the output not required for home use goes to Japan. There is, however, a small but growing export to the Pacific Coast of the United States which at least suggests the possibility of important future development.

On the whole it would appear that China is exporting a 
sufficient quantity of the heavy bulky materials of a sort for which the United States could readily furnish a market to make it reasonably certain that vessels carrying out manufactured goods from our shores to the Orient need not return empty.

\section{JAPAN}

IMPORTS FROM JAPAN

(items of $\$ 10,0 \infty$ and over only)

Annual averages in millions of dollars

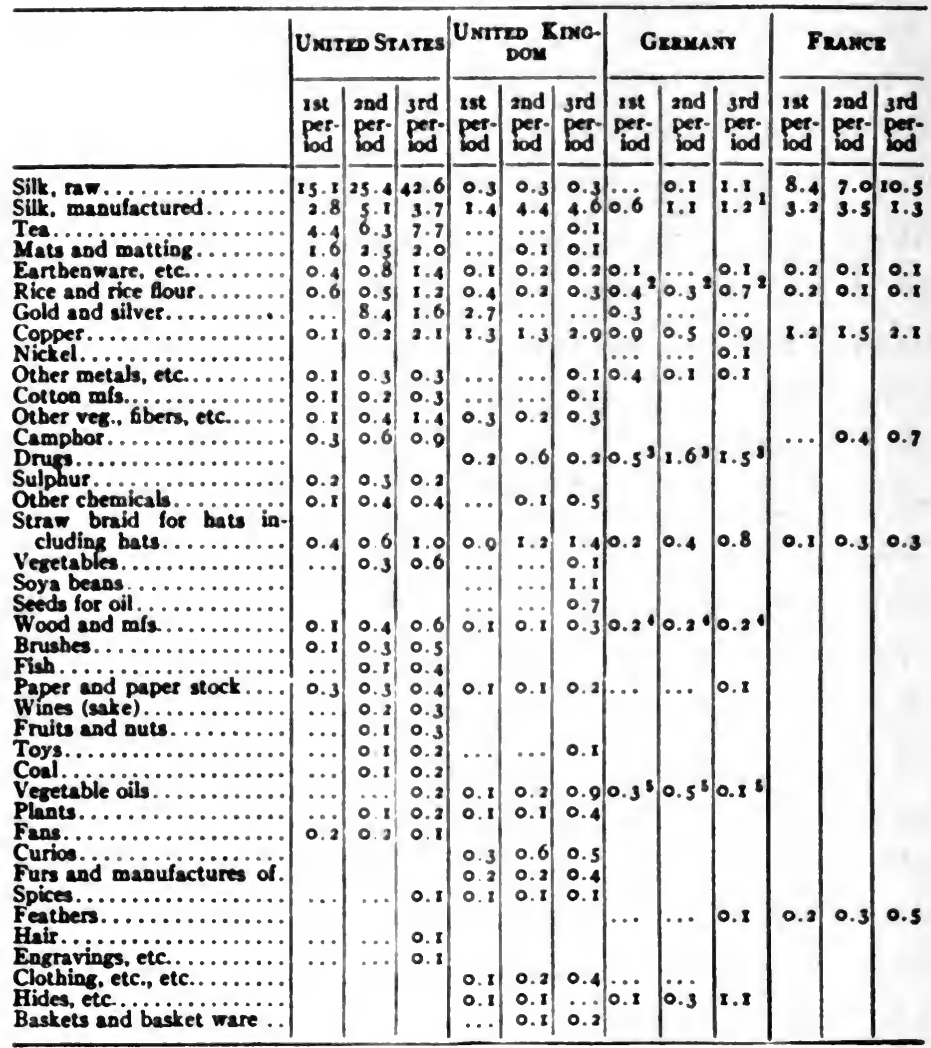

ISpecial trade only.
Includes other grains, etc. "Fostly camphor.

- Includes fats. 
What has just been said in regard to China applies equally to Japan. Japanese exports to Europe and America, if measured in values, consist mainly of silk and tea, goods of high value per unit of weight; yet there is nevertheless a long list of the bulkier cheaper sort of goods which find a ready market among the western nations and which are in rapidly increasing demand. Some of the more important of these are mats and matting, earthenware, rice, copper and other metals, sundry vegetable fibers, straw braid, wood and woodenware, fish, paper and paper stock, sake, etc. For all of these commodities as well as for a number of less important ones, the United States either is or is tending rapidly to become the chief market. In mats and matting, earthenware, rice, vegetable fibers, vegetables, wood and woodenware, fish, paper, sake, and several others, we import more, and in some cases much more than England, Germany, and France combined; and our trade is rapidly growing. Between I897-I90I and I907-I9II our imports of mats and matting rose 22 per cent.; of earthenware, 274 per cent.; of rice, roo per cent.; of fibers, 885 per cent.; of vegetables, I4I 2 per cent.; of wood and woodenware, 3I4 per cent.; of fish, I627 per cent.; of paper and paper stock, I3 per cent.; of sake, 730 per cent. A similar growth is shown even in those articles for which the United States does not yet furnish the chief market. England, for example, purchases more of the Japanese copper output than does the United States, but while England's import has grown since I897-Igor from an annual average value of $\$ 1,339,000$ to $\$ 2,878,000$. in 1907-rgII, the American pur- 
chases have risen from an insignificant $\$ 78,000$ to $\$ 2,060,000$, a figure which is not far behind England's. Even in 1902Igo6 our copper imports were far behind either England's, Germany's, or France's; yet we have now far passed Germany, are on an equality with France, and, as already stated, not far behind England. Similarly, while England is still a larger purchaser than the United States of straw braid, etc., our imports have grown 169 per cent. since 1897-1901 and England's only 67 per cent. German imports have increased more rapidly even than ours, but our purchases still exceed Germany's by nearly one-fourth.

There are several other items of this cheap bulky class of goods in which the American market might easily be expanded. Such, for instance, are vegetable oils, plants, furs, and baskets and basket ware, the bulk of which at present go to England; or feathers, most of which now go to France; or hides, which are purchased by Germany to the value of over $\$ r, \infty \infty, \infty)$ per annum. These are articles which the United States is importing in large quantities from various parts of the world and there seems to be no reason why under favorable conditions Japan should not be added to our sources of supply.

Turning now for a moment to the other class of goods, those which are light and highly valuable, we find still further indication of the growing importance of the United States as a market of Japanese products. We are purchasing raw silk and silk manufactures to the value of $\$ 46,320,000$ per annum, a sum which is more than twoand-one-half times as large as the purchases of England, 
Germany, and France together: in 1897-1901 our purchases were only about 5o per cent. larger than those of France alone. Japanese tea finds almost its sole market in the United States and our imports have increased from $\$ 4,420,000$ per annum in 1897 -1901 to $\$ 7,720,000$ in $1907-$ I9II, or 75 per cent. Only in such relatively unimportant items as camphor and other drugs, chemicals, curios, clothing, etc., do any European countries exceed us in their purchases and even in several of these articles our trade is expanding rapidly, though in some cases the increase is not so large as that of our European rivals. The aggregate value of the Japanese export of these items, however, does not reach more than a small fraction of the value of the silk and tea trade. 


\section{Australia and New Zealand}

IMPORTS FROM AUSTRALIA AND NEW ZEALAND

(items of $\$ 100,000$ and over only)

Annual averages in millions of dollars

\begin{tabular}{|c|c|c|c|c|c|c|}
\hline & \multicolumn{2}{|c|}{ Uxtred States } & \multicolumn{2}{|c|}{ UntrED KrNGDOM } & \multicolumn{2}{|c|}{ Gexum } \\
\hline & $1902-\infty$ & $1907-11$ & $1902-\infty 6$ & $1907-11$ & $1003-\infty$ & $2007-12$ \\
\hline 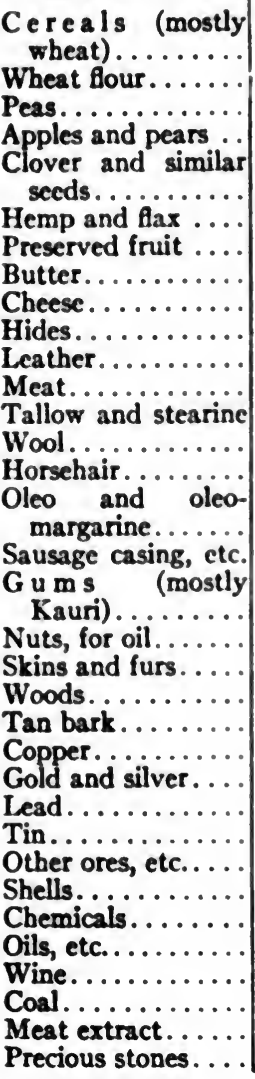 & $\begin{array}{l}0.2 \\
0.8 \\
0.2\end{array}$ & $\begin{array}{l}\cdots \\
1.5 \\
0.5\end{array}$ & $\begin{array}{r}12.8 \\
1.2 \\
\ldots \ldots \\
1.1 \\
0.3 \\
3.0 \\
0.2 \\
14.7 \\
1.1 \\
0.3 \\
2.2 \\
26.5 \\
5.8 \\
74.2 \\
\ldots \ldots \\
\\
\ldots . .3 \\
0.3 \\
1.7 \\
0.6 \\
6.7 \\
1.7 \\
0.2 \\
5.7 \\
27.6 \\
4.2 \\
3.1 \\
0.5 \\
1.9 \\
0.1 \\
0.6 \\
0.6\end{array}$ & $\begin{array}{r}22.9 \\
0.9 \\
0.1 \\
1.7 \\
0.3 \\
2.2 \\
17.8 \\
22.8 \\
4.9 \\
1.2 \\
2.1 \\
39.1 \\
9.7 \\
104.0 \\
0.1 \\
\\
0.3 \\
0.6 \\
\\
2.8 \\
1.9 \\
10.8 \\
1.0 \\
12.0 \\
7.7 \\
17.4 \\
4.2 \\
3.6 \\
0.6 \\
1.5 \\
0.1 \\
0.7 \\
0.6\end{array}$ & $\begin{array}{l}0.1 \\
0.3 \\
0.3 \\
0.2 \\
0.9 \\
0.3 \\
4.81 \\
\\
0.1 \\
0.1 \\
0.5\end{array}$ & $\begin{array}{l}0.2 \\
1.7 \\
5.9 \\
1.1 \\
8.5^{1}\end{array}$ \\
\hline
\end{tabular}

1 About $\frac{1}{8}$ lead and $\frac{1}{8}$ zinc. 
The United States plays but a very insignificant part as a market for Australasian products. The reason, of course, is partly political through the colonial relations of Australia and New Zealand with the mother country, but mainly economic through the similarity of products of these countries and the United States. Of many of the export commodities of both New Zealand and Australia-agricultural, pastoral, and mineral products - the United States is also a large producer and exporter. In spite of the fact that we are rapidly approaching a time when our enormous supplies of foodstuffs will be needed by our own population, it is likely that many years must elapse before we shall be obliged to import any considerable quantities of cereals, meats, or dairy products except for the purpose of supplying local demand in such sections of our country as the Pacific Coast where supplies of this sort are relatively small. Whatever possibilities of development in the near future may exist, would seem to be connected with expanded demand for certain Australasian minerals for use in our metal manufactures and such pastoral products as wool, hides, furs, and skins. These are all, except the precious metals, cheap and bulky commodities and would furnish abundant return cargo for any vessels which might carry out American manufactures if only there were sufficient demand for them in the markets of the United States. This, in turn, will depend upon whether the American fiscal policy can be made permanently and definitely to favor importation by permitting the entry of these goods into the United States as freely as they enter England. Wool, 
hides, skins, and furs, and copper may be regarded as the chief offerings for return cargo and it is interesting to note that in spite of the fact that our trade in these commodities is so insignificant, our imports are already on the rise. Our import of hides has grown from $\$ 1,180,000$ per annum in 1902-1906 to $\$ 1,500,000$ in 1907-1911; of wools, from $\$ 4,020,000$ to $\$ 7,200,000$; of skins and furs, from $\$ 240,000$ to $\$ 540, \infty 00$; and of copper from a figure so small as not to be separately stated in our records to nearly $\$ 3, \infty 00,000$ per annum. These are, of course, but the merest beginnings. Our imports of wool are only about one-fifteenth as large as England's and one-fifth as large as Germany's. England's purchases of skins and furs are twenty-one times as large as ours. Germany purchases a much larger quantity of Australasian hides than we do and England nearly three times as much copper. Nevertheless the figures are at least significant as indicating possible lines of development.

The other items of American import from Australia do not offer much promise of expansion with the possible exception of Kauri gum from New Zealand. Our imports have grown from $\$ 840,000$ per annum to $\$ 1,460,000$, and although our purchases are still only one-half those of England they are gaining rather more rapidly. This item is, however, a relatively small one in the list of Australasian exports and does not promise great future development as the supplies of the gum are limited. 


\section{The Philippine Islands}

\section{IMPORTS FROM THE PHILIPPINE ISLANDS}

(items of $\$ 100,000$ and over only)

Annual averages in millions of dollars

\begin{tabular}{|c|c|c|c|c|c|c|c|c|c|}
\hline & \multicolumn{3}{|c|}{ United States } & \multicolumn{3}{|c|}{ UNITED KINGDOM } & \multicolumn{3}{|c|}{ Germany } \\
\hline & $1897-01$ & $1902-6$ & $1907-11$ & I897-OI & $\mid 902-6$ & $\mid 1907-11$ & I897-0I & $|1902-6|$ & $\mid 1907-11$ \\
\hline Manila..... & $3 \cdot 7$ & 10.0 & 9.2 & 6.5 & 9.2 & $7 \cdot 7$ & 0.4 & 0.4 & 0.6 \\
\hline Other vegeta- & & & & & & & & & \\
\hline ble fibers. & 0.1 & $\cdots$ & O.I & & & & & & \\
\hline $\begin{array}{r}\text { Tobacco and } \\
\text { mfs. of ... }\end{array}$ & 0.7 & & & & & & & & \\
\hline Sugar ...... & $\ldots$ & 0.9 & 2.7 & I.I & $0 . \mathrm{I}$ & 0.2 & & & \\
\hline Cocoanuts .. & .. & $\ldots$ & 0.4 & & & & & & \\
\hline Cocoanut oil & & & & 0.2 & 0.2 & 0.4 & $\cdots$ & $\cdots$ & 0.2 \\
\hline
\end{tabular}

The figures of imports from the Philippines call for but little comment. Almost the only things which these islands produce for export are manila, sugar, cocoanuts and cocoanut oil, and tobacco and manufactures thereof. The first three are well suited to supply return cargo possibilities and the United States is rapidly becoming the chief and in some cases the sole market for them. In 1897-I90I England took nearly twice as much of the output of manila as we; now our purchases exceed hers by over 20 per cent. In I897-I90I England took practically all the Philippine sugar; now the United States gets all but a small fraction. In the earlier period, American purchases of cocoanuts and cocoanut oil were too insignificant to be entered separately in our records; they now equal England's. Unless conditions should be altered seriously, there would seem to 
be every probability that as Philippine production increases, the products will be such as the United States is ready to buy and that the trade will be more and more concentrated in American hands.

This analysis of the details of the import trade from the Pacific countries, taken in connection with the facts previously brought out in regard to the development of exports to them, make clear several points of the utmost significance to the future of our commerce. Our export trade is undergoing a transformation which is reducing the relative importance of our sales of mere bulk commodities and raw materials and increasing the proportion of more highly manufactured goods. At the same time the character of our import trade is changing and we are receiving in exchange for our exports an increasing proportion of heavier, bulkier articles and a declining proportion of lighter, higherpriced goods. These two tendencies together are bringing and are likely to continue to bring about a closer correspondence between outward and inward cargo space demands, and hence are making for the removal of one of the important handicaps under which American exporters have labored. The growth of our import trade in general, both as regards the total value of our purchases and in the greater number and variety of the products of the Pacific countries for which we are able to furnish a market is another factor favorable, in the manner indicated in the early pages of this chapter, to the further expansion of our trade. 


\section{CHAPTER IX}

\section{CONCLUSION}

Never since the completion of the Suez Canal has an event occurred in the field of international commerce so fraught with new opportunities as the opening of the waterway across the Isthmus of Panama. A vast region bordering the Pacific, with huge population and enormous resources, crying out for economic development, is being brought into a new relationship with the older economic sections of the world best able to aid them in the fulfillment of their desires. These Pacific countries all need European and American capital. All of them except the Oriental ones need immigrant population; all except Australia and New Zealand and the Pacific States of the United States and British Columbia need the stimulus and direction of American or European enterprise. Their latent resources can only be made full use of by the development of transportation facilities, railways, roads, harbor and street improvements, modern sanitation, public works of all sorts. Their industries need the introduction of modern equipment and methods. Little of progress can come until these needs are provided for.

Many of the countries in question recognize these facts already and are moving in this direction; many others need 
an awakening to their own shortcomings: it is the economic mission of the older regions like Europe and the United States to furnish aid to these younger nations. Capital, instruction, equipment, stimulus, management - even population-must be supplied to the Pacific by the Atlantic. Already the movement is in this direction. The statistical record of the past ten or fifteen years reveals the fact and every consular report or traveller's record confirms it. Europe and the United States are supplying the Pacific countries in increasing proportions with these things which they most need.

Into the midst of a movement already under way, a new factor, the Panama Canal, is being introduced. A new facility of intercourse has suddenly been created. Goods, tourists, agents, mails, emigrants, can, by the new waterway, more quickly and conveniently reach many of the Pacific countries. New growth of economic, commercial, social, intellectual, political intercourse must inevitably follow. The opening of the canal must, therefore, first of all, be the harbinger of new opportunities and new development in the Pacific countries themselves: it will be the economic privilege of Europe and the United States to respond to their call.

The geographical position of the canal and the trend of development in the Pacific countries are such that the eastern United States, of all Atlantic countries, is the one most favorably situated to play a part in this new growth. With reference to many Pacific regions the United States has hitherto been at a disadvantage compared to Europe: 
with most of these the handicap is either converted into an advantage by the canal, or greatly reduced. In those regions where the United States has already held some advantage, our position is greatly strengthened by the facilities offered by the new route. We are in a position to become, if we choose to seize the opportunity, the dominant factor in the economic and commercial development of a large part of this Pacific area.

Whether or not the United States will grasp this opportunity depends upon numerous factors many of which, however, rest within the determination of our manufacturers and traders themselves. The chief obstacle to the expansion of American foreign trade has been for many years, and to a large extent still is, the superior attractiveness of our domestic markets. The internal trade of the country exceeds many fold the total foreign trade of all the countries of the world together and until recently this huge market has seemed to offer possibilities of almost indefinite expansion. Protected by a high tariff wall, largely independent of foreign supplies of many materials through the extent and variety of natural resources, catering to a rapidly increasing home population, our manufacturers' chief business has naturally been to supply needs arising within our own borders. But experience has abundantly shown that foreign trade does not permanently flourish as a mere by-industry. The development of a really great commerce with the countries of the Pacific can only come if our great traders and manufacturers have reached a stage in the development of their business in which they 
will find it worth while to go out after foreign trade with the same energy and determination which has characterized their pursuit of the domestic markets.

The next pre-requisite to the development of a really large commerce with the Pacific will be the wise choosing of the lines along which energy is to be directed. It is relatively hopeless to attempt great expansion in regions in which all the economic conditions are favorable to our rivals or in lines of goods in which the market, even though large, does not show a capacity for growth. Conversely, the most promising policy for the trader or manufacturer to pursue is to make his attack in those regions where natural conditions are favorable and in those classes of goods which are singled out as a result of economic development in the market countries as being in the line of necessary growth.

The preceding chapters of this book have attempted to present the material upon which to base some judgment as to the direction and character of the trade which lies most ready to hand and gives most promise of easy development. The countries where our advantages become greatest, as a result of the opening of the Panama Canal, are those which border the eastern shores of the Pacific. To all points, from Chile north to Alaska, the canal will give the people of our Atlantic and Gulf States enormously increased facilities, quick service, lower freights, new knowledge through increased personal intercourse, new opportunities for investment. It will probably be in our relations with these countries that the most immediate effects of the opening of the canal will be felt. To a less degree Japan and Australasia 
will also offer opportunities, and even northern China and northeastern Asia generally; but the relative strength of the United States and Europe, here, will be much more evenly balanced, and any advance which we may make toward a more abundant control of the markets must be the result of much more conscious and persistent effort on our part. In southern China, Siam, the East Indies, and southeastern Asia generally, there is no reason to suppose that the canal will exercise any considerable influence. There may, in time, come a growth of our trade there; but it is far more likely to be as an indirect result of a general expansion of our business than as a direct consequence of the opening of a new waterway. Direct effort there for the development of trade is not likely to have any results which would be commensurate with the reward which would come from similar effort directed toward some of the other countries mentioned.

The tables and comments which have been presented covering the character and growth of the export and import trade of the Pacific countries give many pointed indications as to the character of goods in which our traders might reasonably expect to meet with success. The United States has long sent large quantities of foodstuffs to the Pacific countries; we once sent considerable amounts of cotton goods and clothing and we have from time to time spent large amounts of money and time in endeavors to discover why our trade in these goods was declining or in attempts to revive it. The truth is that, as a whole, the Pacific region is moving economically in a direction which will bring it 
into a position of relative independence of both Europe and the United States for goods of this sort. All the Pacific countries except China, Japan and Alaska are abundantly able to feed themselves and are making increasing provisions to do so. Commerce in foods will undoubtedly continue, but it will not deal with the great mass of bulk foodstuffs, but confine itself to supplying certain sections of the Pacific area, notably the tropical regions, with canned and other preserved foods which the warm climates cannot produce. The tropical Pacific lands within the zone of influence of the Panama Canal, are the smallest in area and population and give least promise of economic growth. In Japan, if that country's astonishing industrial development continues; and in China if the long-promised industrial awakening really comes; large quantities of foreign foodstuffs, especially breadstuffs, will unquestionably be required. But all the indications point against any great or lasting dependence upon the United States for such supplies. On the one hand, American breadstuff export is declining and is likely to continue to decline; and, on the other, both Japan and China are developing new sources of supply in Korea, Manchuria, Mongolia, and Siberia.

Concerning cotton goods and clothing very similar conditions exist. Nearly every country bordering the Pacific produces raw cotton or some other fiber suitable to furnish the material for the clothing of the mass of the people, and is showing itself determined and able to produce, under the protection of a tariff wall, an ever increasing proportion of the goods of this sort which its people require. The im- 
portant exceptions are the Pacific States of the United States, British Columbia, Alaska, Australia and New Zealand. These do and will continue to import large quantities of cottons but there appears to be no reason to expect that American mills will supply any but the most insignificant part of the demand except to the Pacific slopes of the United States itself, and possibly to some degree, to British Columbia. The greatest of all these markets, the Australasian, belongs so definitely to the mother country through long custom, a preferential duty, and lower prices of British goods, that the slight advantage which will be given to American shippers through the opening of the Panama Canal is not at all likely to make any alteration.

The great opportunity for the development of American trade with the Pacific countries lies in the possibility of our seizing a larger share of the rapidly increasing commerce in the numerous products of other than the textile manufacturing industries. The direction of growth seems already to be clearly apparent. The statistics of trade reveal innumerable instances of increasing purchases of goods of this kind and there is every reason to believe that the same sort of development will continue and be stimulated by the opening of the canal. A stir of new economic life, the growth of closer intercourse with Europe and the United States, and new European immigration will all tend to make necessary or to create a taste for the multitudinous highly specialized products of European and American factories, goods which it is utterly impossible for any of the Pacific countries to produce in any but insignificant quantities. They will, in 
all probability, be purchased from Europe and America in even more rapidly increasing amounts than during the ten or fifteen years for which statistics have been presented. The United States is clearly in a position to supply many of the goods in question, for she is already the largest producer in the world of many of them.

Pre-eminent among manufactures of this sort are clearly the various materials of construction, especially of iron and steel. In spite of the progress which has been made in several of the Pacific countries in the past decade or two, enormous amounts of constructive engineering work remains to be done and will be a necessary part of the general economic development. Railroads, bridges, dams, warehouses, docks, quays, lighthouses, factories, etc., are being and will continue to be built. Iron and steel are increasingly the basis of modern construction, yet not one of the Pacific countries produces them in any considerable quantity or is likely to produce them in the near future. One country, only, in the entire list-China-is known to possess large quantities of both iron ore and fuel. The time may conceivably come when this country will be able to turn out iron and steel in competition even with the United States, England, or Germany, and many enthusiastic predictions have been made as to the rapidity with which such a period is likely to arrive, yet the fact remains that in spite of some years of development at Hankow, the output remains insignificant. Several other Pacific countries have the ore but lack the fuel, as in California, or have the fuel and lack the ore, as in Japan, but none, with the 
possible exception on a small scale, of Australia, has both. For a long time to come, if not indefinitely, the Pacific countries must depend on the United States and Europe for the supply of these goods.

Closely allied to these structural iron and steel materials are general railway materials and all sorts of machinery. Railway construction on a large scale must come in all the Pacific countries. With the exception of a small portion of Australia, parts of the Pacific coast of the United States, and Japan, the whole Pacific region is wretchedly supplied with transportation facilities of this sort. The growth of the needed roads will bring a demand not only for the construction materials such as rails but for locomotives, cars, carwheels, etc. Street railway development will call similarly for cars and motor machinery. The reorganization on modern lines of the industries of the various countries, from the extractive industries of Chile, Peru, or Mexico to the more elaborate textile industries of Japan or China, will likewise increase the demand for machines; and so on through a long list. Industrial development of whatever sort will call increasingly for machine equipment: mining machinery for the great mineral region extending from southern Chile to Alaska; agricultural machinery for the valleys of southern and central Chile and the western region of the United States, for Australia and New Zealand; weaving and spinning machinery for Japan and China; machinery for the growing dairying industry of New Zealand; refrigerating machinery for the meat industry in Australasia or Chile; pumps, windmills, electric motors, 
computing machines, for the ranches or the offices in many of the Pacific lands; machine equipment for the shops and factories of Japan or southeastern Australia; all these are but illustrations of the lines of trade which may be developed. Materials for electric lighting and electric power plants, telegraph and telephone lines, wireless stations, irrigation works, water supply plants; wire, hardware, tools, vehicles of all sorts: these are all things which must be had which the United States can supply. In addition there are numerous commodities less directly connected with industrial development but inevitably increasing in demand as an accompaniment of economic growth; books, paper, cosmetics, rubber goods, household utensils, furniture and cabinet ware, medicines, porcelain, glassware, paints and varnishes, brooms and brushes, leather goods, etc., and many of these also the United States might supply.

Already in a goodly number of these goods the United States has been making a fair showing, the degree of success varying in different commodities and in different countries. Success under past conditions gives an indication of what may be called the lines of least resistance-the lines along which, if our exporters make up their minds to enter seriously and deliberately into the competition for the markets, it will probably be wisest to make the first attacks. Success along a few well chosen lines will then operate as a stimulus along others as well, and in time give the United States a large share of the market for a very considerable number of the commodities enumerated.

The prime requisites are that American manufacturers 
and traders should choose their point of attack wisely, should embark in the new enterprise deliberately, and should make up their minds to persevere until success has been attained. There has been too much holding back to await a time when every element should be favorable; too much complaint about lack of shipping facilities or banking facilities, or risks involved in the lack of reliable commercial and credit information, or the difficulty of obtaining return cargoes. These things do represent handicaps under which the American exporter labors; they can not be lightly disregarded; yet the experience of such American concerns as have operated persistently and perseveringly in foreign markets abundantly proves that with the development of trade these difficulties in a way take care of themselves. The growth of trade brings with it the development of the other things. If regular trade offers ships will be found to carry it, banking connections will be developed to handle it, new commercial and credit information will accompany it. Only in the early stages will the difficulties be so great as to be likely to result in loss. Small exporters, operating individually, naturally cannot take the risks involved, but large exporters, or large combinations of small exporters, able and willing to face initial losses, and going into the enterprise only after careful investigation of the markets and all the elements of the situation will unquestionably find that profitable business awaits them.

The United States is clearly entering upon a new era in foreign trade. The rapid transition of the past twenty years, which has transformed us from a foodstuff and raw 
material exporter into a manufactures exporter, is forcing upon us a new interest in foreign markets; and, as a sort of climax, the completion of the great engineering feat at Panama is at this moment opening to us as a nation a great new opportunity by bringing a huge rapidly growing trade area more definitely within our commercial reach. 


\section{APPENDIX}





\begin{tabular}{|c|c|c|}
\hline 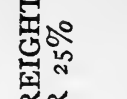 & 雚苋 & 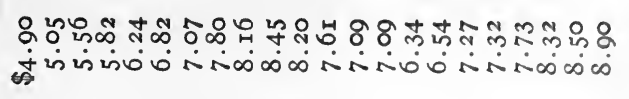 \\
\hline 8 & 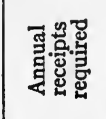 & 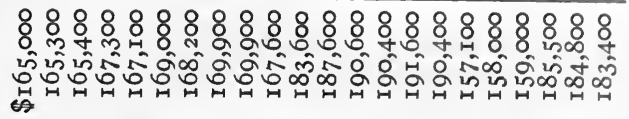 \\
\hline 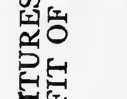 & 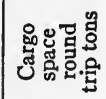 & 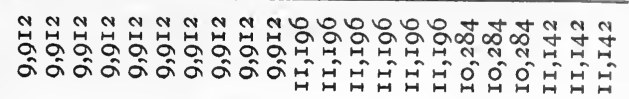 \\
\hline or & 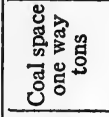 & 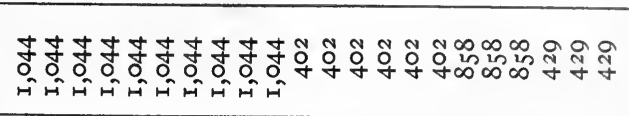 \\
\hline 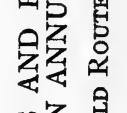 & 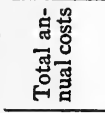 & 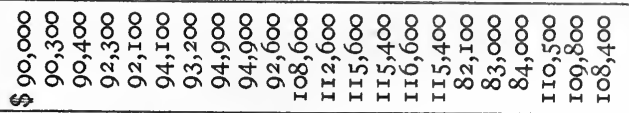 \\
\hline 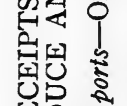 & 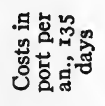 & 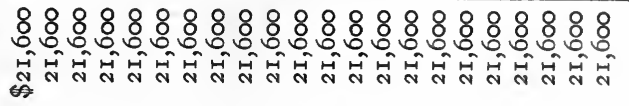 \\
\hline 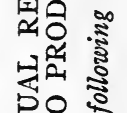 & 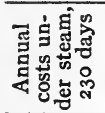 & 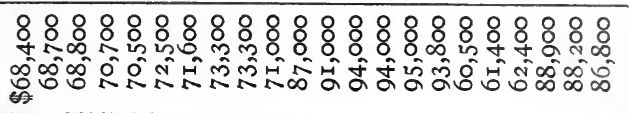 \\
\hline 要 & 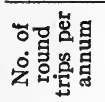 & 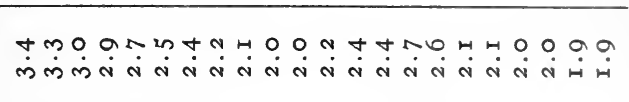 \\
\hline : & 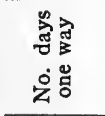 & 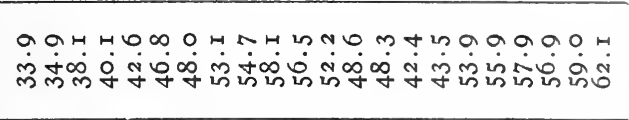 \\
\hline जी & 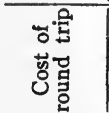 & 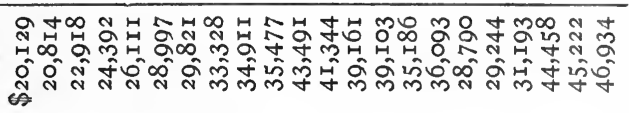 \\
\hline & 竞 & 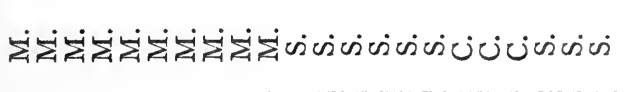 \\
\hline 8 & & 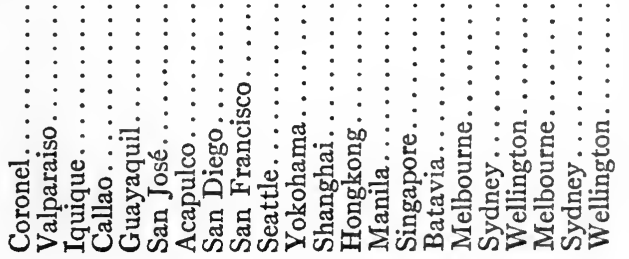 \\
\hline
\end{tabular}




\begin{tabular}{|c|c|c|}
\hline$\sum$ & 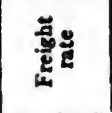 & 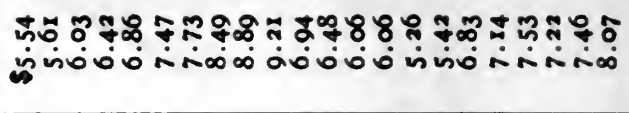 \\
\hline 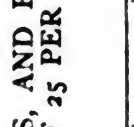 & 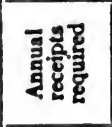 & 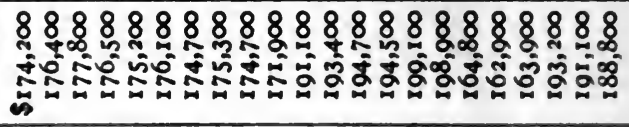 \\
\hline & 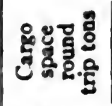 & 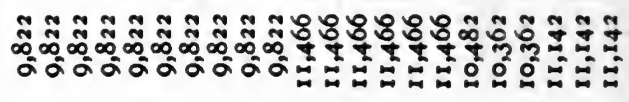 \\
\hline 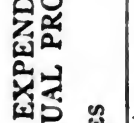 & 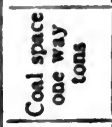 & 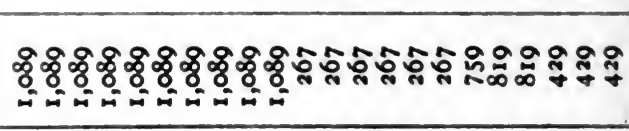 \\
\hline 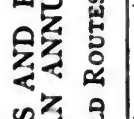 & 这亭 & 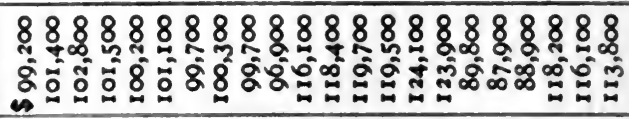 \\
\hline 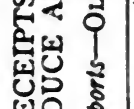 & 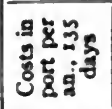 & 8888888888888888888888 \\
\hline 密 & 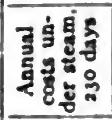 & 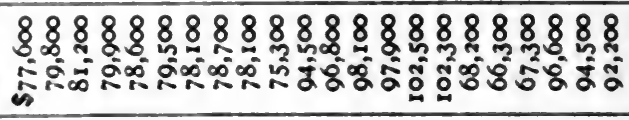 \\
\hline$\frac{1}{8}$ & 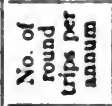 & 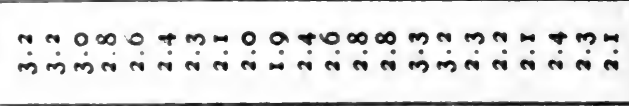 \\
\hline 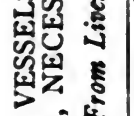 & 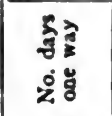 & 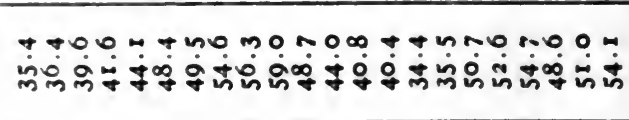 \\
\hline & 证 & 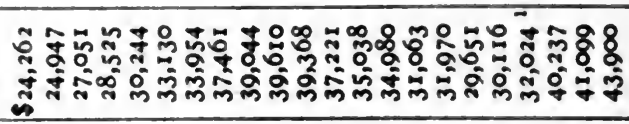 \\
\hline & 产 & 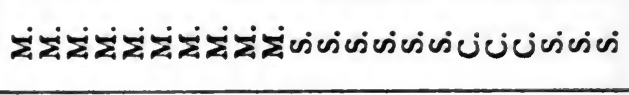 \\
\hline & & 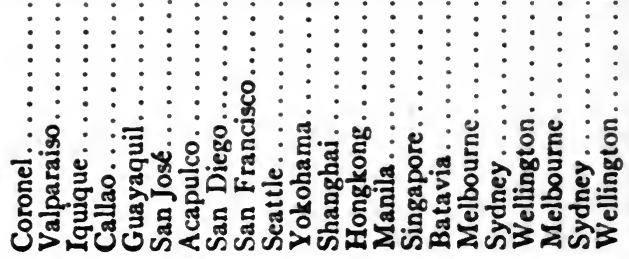 \\
\hline
\end{tabular}




\begin{tabular}{|c|c|c|}
\hline \\
\hline \multirow{10}{*}{ 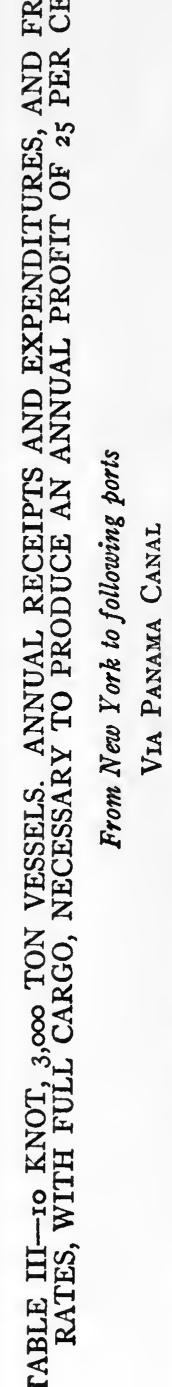 } & 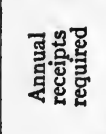 & 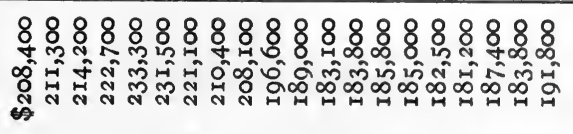 \\
\hline & 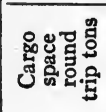 & 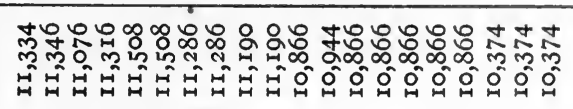 \\
\hline & 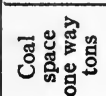 & 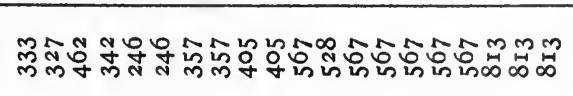 \\
\hline & 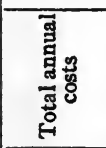 & 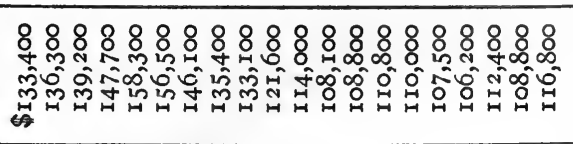 \\
\hline & 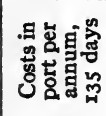 & 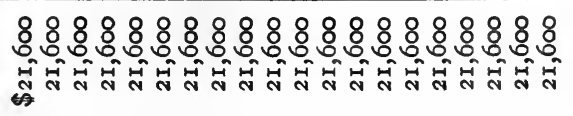 \\
\hline & 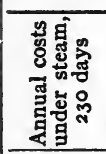 & 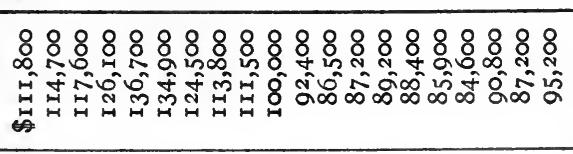 \\
\hline & 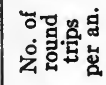 & 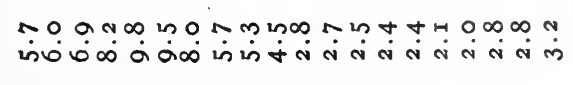 \\
\hline & 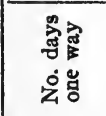 & 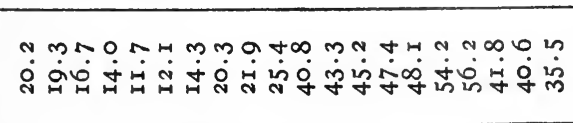 \\
\hline & 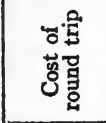 & 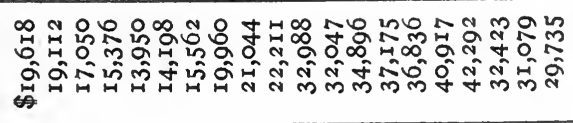 \\
\hline & & 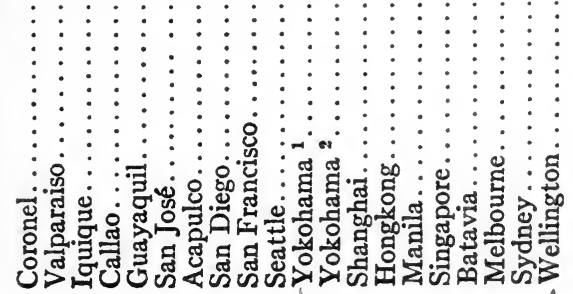 \\
\hline
\end{tabular}


菢

资

in

幽

5

본

要

हद

에

Uن

มุ

쇼요

숭

帘

z.

$\alpha$

نं

곤

.

ติบ

돈

중요

83

ind

is

이

$z$

资

0

$>$

to

잉

象

\&

\begin{tabular}{|c|c|}
\hline 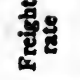 & 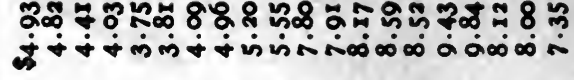 \\
\hline 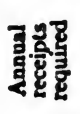 & 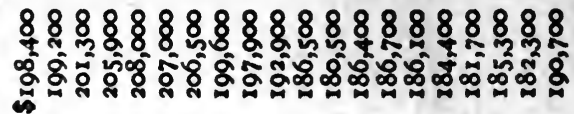 \\
\hline
\end{tabular}

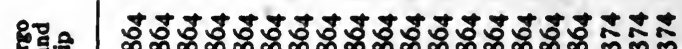
క్ 000000000000000000

牙青

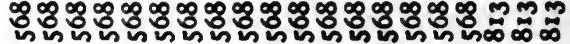

要 888888888888888888

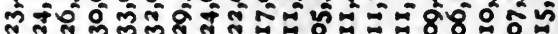

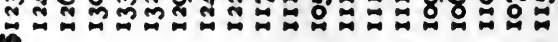

3

7. 88888888888888888888

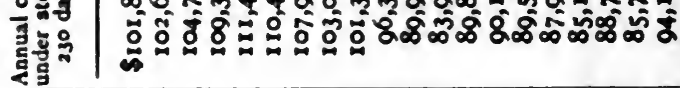

no $N$ No 0 n

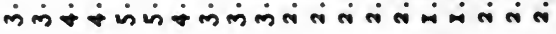

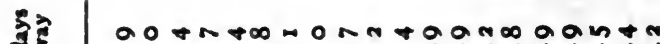

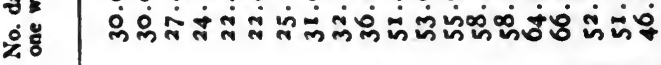

-

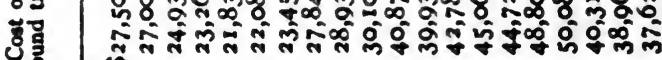
8 


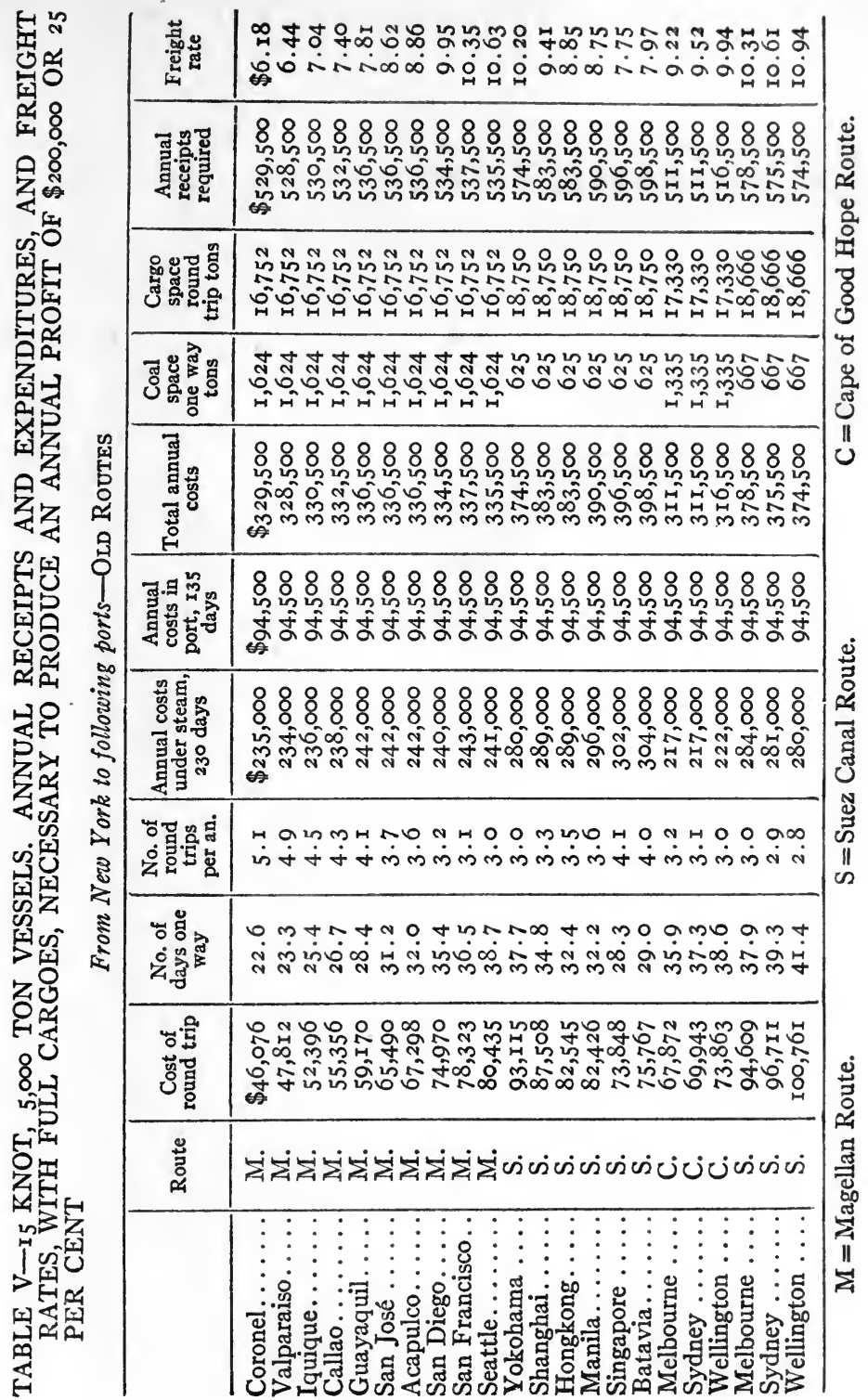




\begin{tabular}{|c|c|c|}
\hline $\bar{z}$ & 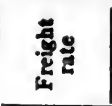 & 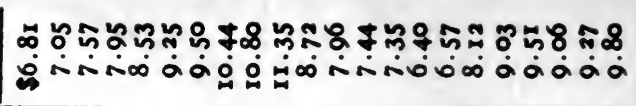 \\
\hline a) & 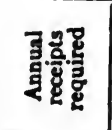 & 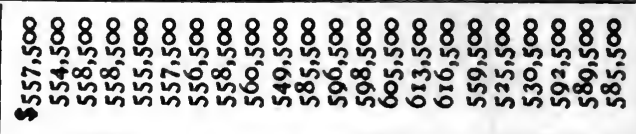 \\
\hline 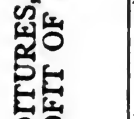 & 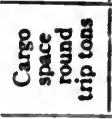 & 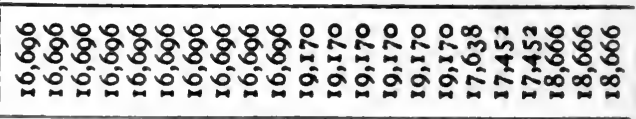 \\
\hline r & 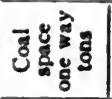 & 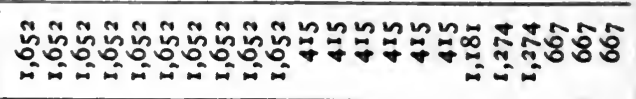 \\
\hline 递 & 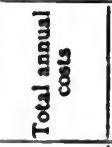 & 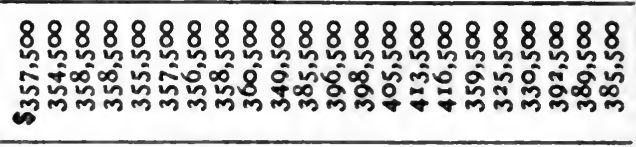 \\
\hline I & 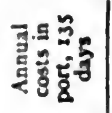 & 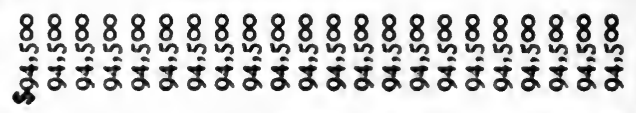 \\
\hline 0 & 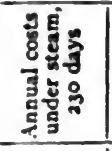 & 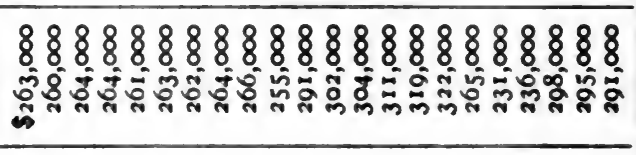 \\
\hline$\tilde{E}$ & 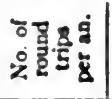 & 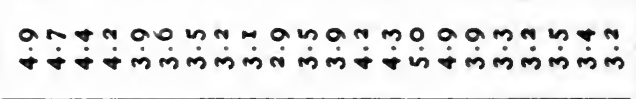 \\
\hline & 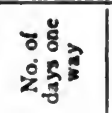 & 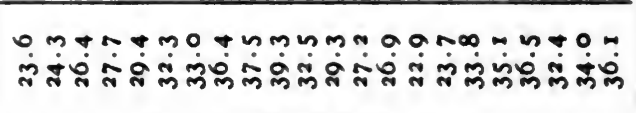 \\
\hline & है: & 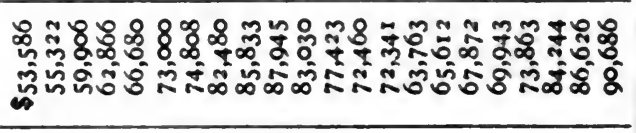 \\
\hline & 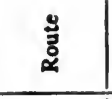 & 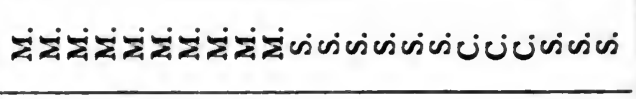 \\
\hline & & 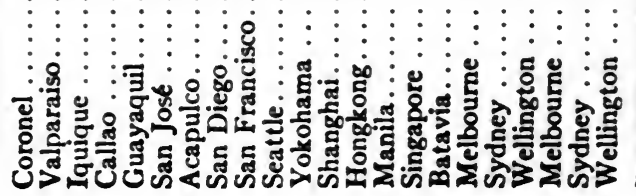 \\
\hline
\end{tabular}




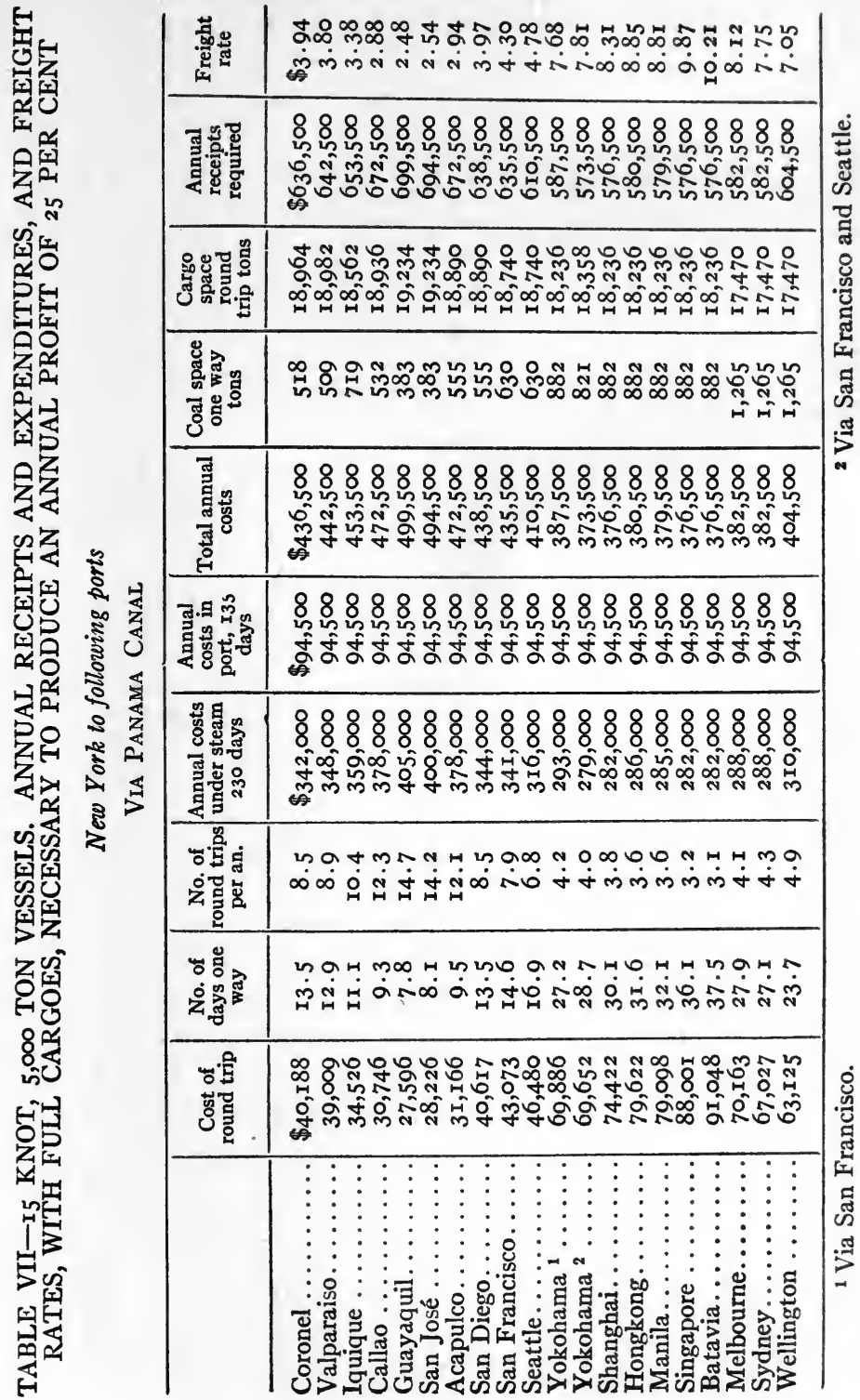




\begin{tabular}{|c|c|c|}
\hline$t$ & 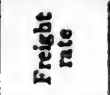 & 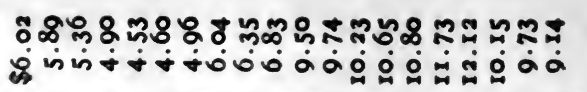 \\
\hline 2 & 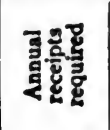 & 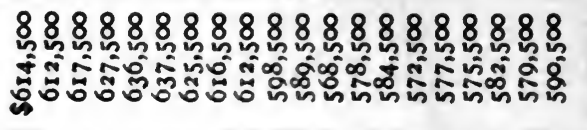 \\
\hline & 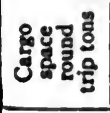 & 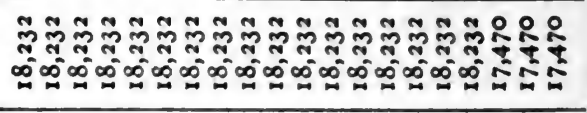 \\
\hline 4 & 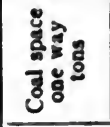 & 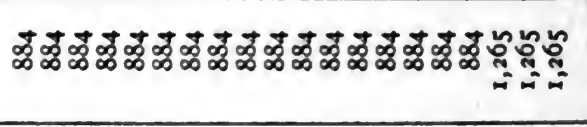 \\
\hline 交 & 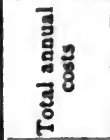 & 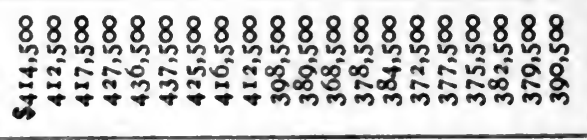 \\
\hline 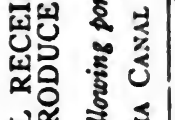 & 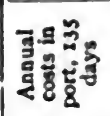 & 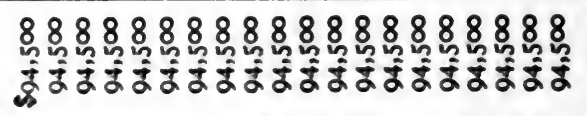 \\
\hline 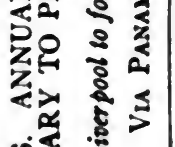 & 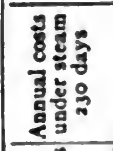 & 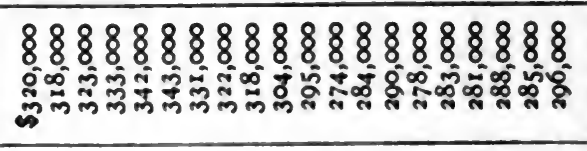 \\
\hline 串 & 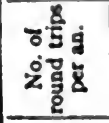 & 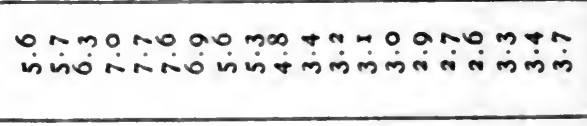 \\
\hline & 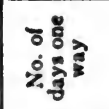 & 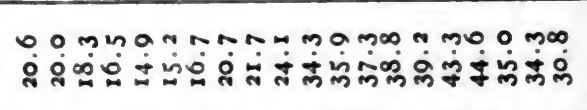 \\
\hline بُ & 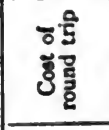 & 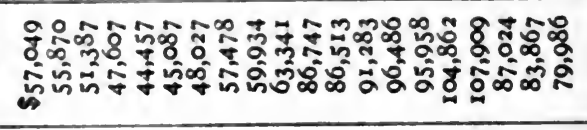 \\
\hline$E$ & & 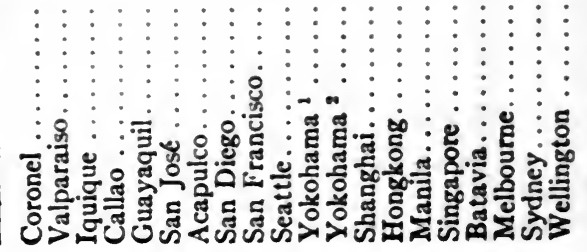 \\
\hline
\end{tabular}




\section{INDEX}

\section{A}

Acapulco, choice of routes to, from Liverpool and from New York, $32,35,36$ ff., 255-262

Adding machines. See Machinery and tools

Advertising, futility of sole reliance on, for pushing American goods in Pacific countries, 90-9I

Aërated waters, exports of, from England to west coast of South America, 176

Agents of foreign business houses in Pacific countries, 93-95

Agricultural implements. See Machinery and tools

Alaska, American control of commerce of, 130

Animals, exportation of, from Australia, 64; imports of, into United States from Mexico, 220, 22I

Antimony, imports of, into England from Mexico, 220; imports into England and Germany from China, 229, 23I

Apparel, exports of, from Atlantic countries to: west coast of South America, I78, I79; China, I87; Japan, I93; Australasia, 203, 204; Philippine Islands, 210, 2 I I

Australasia, British, statistics of trade between Atlantic countries and (I897-I9II), IO3-IO4, II7II9, I27; variety of foodstuffs imported by, and countries which supply, 136; importation of cloth- ing and clothing materials from England chiefly, I4I, I52; sources of imports of iron and steel manufactures, I46-I47, I52; sources of imports of general manufactures, I49, I52; details of export trade of different Atlantic countries to, in: foodstuffs, $20 \mathrm{I}-202$, clothing and clothing materials, 203-204, iron and steel manufactures, 204-206, miscellaneous manufactures, 207-209; analysis of imports from, into Atlantic countries, $236-238$

Australia, rate of population in, per square mile, 49-5I; per capita foreign trade of, 52; character and value of exports of, 59-60, $63-64$; character and value of imports of, 66; countries with which chief trade takes place, 70; distribution of import trade of, 85 ; clothing and clothing material imported principally from England, I4I, 152. See Australasia

Austria-Hungary, statistics as to trade of, with Pacific countries (I897-I9II), IO2-I3I

Automobiles. See Machinery and tools

\section{B}

Bananas, imports of, into Atlantic countries from Central America and Colombia, 62, 217, 218 
Banks, question of disadvantages from lack of American, in Pacific countries, $80-83$

Bar iron and steel. See General structural material

Baskets and basket ware, imports of, into Atlantic countries from Japan, 232, 234

Batavia, choice of routes to, from Liverpool and from New York, $32,35,36,255-262$

Beans and bean cakes, exports of, from China, 64, 229

Beer. See Wine, spirits, and beer

Belgium, statistics as to trade of, with Pacific countries (1897-1911), 102-131

Biscuits and cakes, exports of, from England to: Central America and Colombia, 157; west coast of South America, 176; Philippine Islands, 209

Blacking, export of, from United States to Australasia, 207

Bolivia, per capita foreign trade of, 52; character and value of exports of, 63. See West coast of South America

Books, exports of, from Atlantic countries to: west coast of South America, 182; China, 190; Japan, 199, 200; Australasia, 207, 208; Philippine Islands, 212

Boots and shoes, imports of, into Pacific countries, 65-69; into Central America and Colombia, 157 , 158; into Mexico, 167-168, 169; into west coast of South America, 178; into China, 187; into Japan, 193; into Australasia, 203, 204; into Philippine Islands, 210,211

Borax, production of, by Pacific Coast States, 68
Brass manufactures, exports of, from Atlantic countries to: Japan, 199, 200; Australasia, 207, 208; Philippine Islands, 212, 213

Breadstuffs, exports of, from Atlantic countries to: Central America and Colombia, 156; Mexico, 166; west coast of South America, 175, 177 ; China, 185-186; Japan, 191-192; Philippine Islands, 209; from United Kingdom and United States to Australasia, 201, 202

Bristles, imports of, into Atlantic countries from China, 229, 230, 231

British Columbia, character and value of exports of, $60-6 \mathrm{r}$; commerce of, divided between England and eastern Canada, and United States, 130-131

Brooms, export of, from England and Germany to Australasia, 207

Brushes, import of, into United States from Japan, 232

Butter, export of, from Australia, 64 . See Dairy products

\section{C}

Cabinet woods, imports of, into United States and Germany from Central America and Colombia, 219

Cacao, imports of, into Atlantic countries from: west coast of South America (chiefly Ecuador), 63, 223, 226; Central America and Colombia, 217

California, fruit and wine produced by, 61

Callao, choice of routes to, from Liverpool and from New York, 32, $35,36,255^{-262}$

Camphor, imports of, into United 
States and France from Japan, 64 , 232, 235

Canada, character and value of export trade of, 60-6I

Candles, exports of, from Atlantic countries to: Central America and Colombia, 164, 165; west coast of South America, I82, I84; China, I90, I9I

Canned goods, exports of, from United States to Central America and Colombia, 156

Carpenters' tools. See Machinery and tools

Cars and car wheels. See Railway materials

Cash registers. See Machinery and tools

Castings. See General structural material

Cement, exports of, from Atlantic countries to: Central America and Colombia, I64, I65; Mexico, I74; west coast of South America, 182, I84

Central America, extent of foreign trade of, 52 ; character and value of exports of, 59,62

Central America and Colombia, distribution of import trade of, 85; statistics of trade between Atlantic countries and (I897-IgII), I02-I06, I 22; countries from which foodstuffs were imported into, I33-I34, I52; sources of imports of clothing and clothing materials, 138, 152; sources of imports of iron and steel manufactures, 144, I52; sources of imports of general manufactures, I49, I52; details of exports of different Atlantic countries to, in: foodstuffs, $156-157$, clothing and clothing materials, 157-r6o, iron and steel manufactures, $160-163$, miscellaneous manufactures, I63-I65; analysis of imports from, into Atlantic countries, 2I7-219

Cereals, imports of, into Atlantic countries from: west coast of South America, 223, 226; Australia and New Zealand, 236

Cheese. See Dairy products

Chemicals, imports of, into Atlantic countries from: west coast of South America, 223, 224; China, 229; Japan, 232, 235; Australia and New Zealand, 236

Chemicals and chemical preparations, countries which export, to Pacific countries, 72; exports of, to: Central America and Colombia, I64, I65, Mexico, I74, west coast of South America, I82, I83, China, I90, I9I, Japan, I99, 200, Australasia, 207, 208, Philippine Islands, 2 I 2

Chicle, imports of, into United States from Mexico, 220, 222

Chile, per capita foreign trade of, 52 ; character and value of exports of, 59-60, 63; character and value of imports of, 66; nitrate exports, 223, 224; imports of meat products from, into Germany, 226. See West coast of South America

China, density of population in, $5 \mathrm{I}$; extent of foreign trade of, $5 \mathrm{I}$; conditions affecting foreign trade conditions in, 56-58; character and value of exports of, 59-60, 64; character and value of imports of, 66; countries with which chief trade exists, 70; distribution of import trade of, $85-86$; statistics 
of trade between Atlantic countries and (1897-1911), 103-104, 11x-114, 125; countries exporting foodstuffs to, 135, 152; sources of imports of clothing and clothing materials, 139-140, 152; sources of imports of iron and steel manufactures, 145, 152; sources of imports of general manufactures, 149-150, 152; details of export trade of different Atlantic countries with, in: foodstufis, $185-187$, clothing and clothing materials, 187, iron and steel manufactures, 188-189, miscellaneous manufactures, $189-191$; imports into Japan from, 194; analysis of imports from, into Atlantic countries, 229-232; supplies of iron ore and fuel in, 248

Chinaware. See Farthenware, stoneware, and chinaware

Cigars, imports of, into Atlantic countries from: Philippine Islands, 65; Mexico, 220. See Tobacco manufactures

Circulars, hopelessness of sole dependence on, for selling American goods in Pacific countries, 90-9r

Clays, imports of, into Germany from west coast of South America, 223

Climate, relation between commercial activity and, 52-53

Clocks and watches, exports of, from United States and France to west coast of South America, 182, 183; from United States to: China, 190, Japan, 199, 200, Australasia, 207, 208, Philippine Islands, 212

Clothing and clothing materials, imports of, into Pacific coun- tries, 65-69; increasing manufacture of, by Pacific countries, 67; distribution of trade in, to Pacific countries, 137-142, 152; importation of, to Pacific countries a declining business, 142, 151; analysis of trade of different Atlantic countries in, with: Central America and Colombia, 157-160, Mexico, 167-169, west const of South America, 178-179, China, 187, Japan, 192-194, Australasia, 203-204, Philippine Islands, 210211

Clothing, ready-made. See Readymade clothing

Coal, as a factor in considering manufacturing possibilities of different countries, 76-77; imports of, into United States from Japan, 232; imports of, into Atlantic countries from Australia and New Zealand, 236

Coal products, exports of, from Atlantic countries to Japan, 199, 200 Cocoa, exports of, from United Kingdom to Australasia, 201, 202 Cocoanuts and cocoanut oil, imports of, into Atlantic countries from Philippine Islands, 239

Coffec, imports of, into Atlantic countries from: Central America and Colombia, 62, 63, 217, 218; Mexico, 220, 221; west coast of South America, 223, 226

Colombia, character and value of exports of, 63. See Central Ameri$c a$ and Colombia

Commercial travelers, class of, necessary to send to Pacific countries, $91-93$

Condensed mill, exports of, from England to: west coast of South 
America, 176; Australasia, .20r, 202

Confectionery, exports of, from Atlantic countries to: Central America and Colombia, I56, I57; west coast of South America, I77; China, I85, r86; Australasia, 20r; Philippine Islands, 209

Copper, production of, by Pacific Coast States, 6r; imports of, into Atlantic countries from: Mexico, $62,220,221$, west coast of South America, 63, 223, 224-225, Japan, 64, 232, 233, China, 229, 23r, Australia and New Zealand, 236, 238; exportation of, by United States to Pacific countries, 73; advantage to manufactures in United States, from production of, 78

Copper manufactures, exports of, from Atlantic countries to: Central America and Colombia, I64, I65; Mexico, 174; west coast of South America, I82, I83; China, I9o; Japan, I99, 200; Australasia, 207, 208; Philippine Islands, 21 2, 213

Copra, exportation of, from Philippines, 65

Cordage, exports of, from Atlantic countries to: west coast of South America, 182, 184; Philippine Islands, 2 ro

Corn. See Breadstuffs

Coronel, choice of routes to, from Liverpool and from New York, 32, 34 ff., 255-262

Costa Rica, character and value of exports of, 59-60; character and value of imports of, 66

Cost of service rates from New York and from Liverpool to Pacific ports via present and via new routes, 36
Cotton, imports of, into Atlantic countries from: west coast of South America, 63, 223, 227, China, 64, 229; advantage of United States in production of, for manufacturing purposes, 77 ; export trade of United States in, to Japan, I42-I43; imports of, to Japan from India, I94

Cotton goods, increasing manufacture of, by Pacific countries, 67; exports of, from Atlantic countries to: Central America and Colombia, I57, I58, I59, Mexico, 167, I68, r69, west coast of South America, I78, China, I87, Japan, I93, I94, Australasia, 203, 204, Philippine Islands, 210-2II; imports of, into Atlantic countries from Japan, 232; decreasing demand for, by Pacific countries, 246-247

Cotton-seed oil, export of, from United States to Mexico, I66

Cotton yarn, exports of, from United Kingdom to Japan, I93

Curios, imports of, into England from: China, 229; Japan, 232

Currents, a negligible factor in choice of ocean routes, I8-I9

Cycles. See Machinery and tools

D

Dairy products, exports of, from United States to: Central America and Colombia, I56, Mexico, I66, west coast of South America, I75r76, China, I85, I86, Japan, I92; imports of, into England from Australia and New Zealand, 236, 237

Drugs, imports of, into Germany from Central America and Colom- 
bia (1902-1906), 217; imports into United States from Mexico, 220, 222; imports into Atlantic countries from: west coast of South America, 223, 224, China, 229, Japan, 232, 235. See also Medicines

Dyes, imports of, into Atlantic countries from: Central America and Colombia, 217, 218; Mexico, 220,

222

\section{$\mathbf{E}$}

Earthenware, stoneware, and chinaware, imports of, into Atlantic countries from Japan, 64, 232, 233; exports of, from Atlantic countrics to: Mexico, 174, west coast of South America, 182, 184, China, 190, 191, Japan, 199, 200, Australasia, 207, Philippine Islands, 212, $2 \times 3$

Ecuador, per capita foreign trade of, 52; character and value of exports of, 63. See West coast of South America

Eggs, imports of, into Germany from China, 229

Electrical equipment. See Machinery and tools

Engines. See Machinery and tools

England, export of manufactured goods to Pacific countries by, 71-72; classes of manufactures exported by, 72; position of, in regard to export of manufactures, as compared with United States and Germany, 74-75; steamship service of, to Pacific countries, 85, 218-219; statistics of trade of, with Pacific countries ( $1897-1911$ ), 102-r31; share of, in exports of foodstuffs to Pacific countries,
133-137, 152; share in exports of clothing and clothing materials, 138-142, 152; share in exports of iron and steel manufactures, 144 148, 152; share in exports of general manufactures, 148-150, 152; details of trade of, with Central America and Colombia, in: foodstuffs, 157, clothing and clothing materials, 158, iron and steel manufactures, $161-163$, miscellaneous manufactures, 163-165; details of trade with Mexico in: foodstuffs, 166, clothing and clothing materials, 167-169, iron and steel manufactures, 169-171, miscellaneous manufactures, 174-175; details of trade with west coast of South America in: foodstuffs, $175^{-177}$, clothing and clothing materials, 178-179, iron and steel manufactures, 179-180, miscellaneous manufactures, $18 \mathrm{i}-185$; details of trade with China in: foodstuffs, 185-186, clothing and clothing materials, 187 , iron and steel manufactures, 188, miscellaneous manufactures, 190-191; details of trade with Japan in: foodstuffs, 191-192, clothing and clothing materials, 192-194, iron and steel manufactures, 195-198, miscellaneous manufactures, 199200; details of trade with Australasia in: foodstuffs, 201-202, clothing and clothing materials, 203-204, iron and steel manufactures, 204-206, miscellaneous manufactures, 207-209; details of trade with Philippine Islands in: foodstuffs, 209 , clothing and clothing materials, 210-211, iron and steel manufactures, 211, miscel- 
laneous manufactures, 2I 2-213; imports into, from: Central America and Colombia, 217-219, Mexico, 220-222, west coast of South America, 223-228, China, 229-23r, Japan, 232-235, Australia and New Zealand, 236-238, Philippine Islands, 239

European populations, effect of, in Pacific countries, on commercial activity, 53-55

Explosives, exports of, from Atlantic countries to: Australasia, 207, 208; Philippine Islands, 212. See Chemicals and chemical preparations

\section{F}

Fans, imports of, into United States from Japan, 232

Fashion goods, consumers' taste a determining factor in origin of, 7 ; exportation of, by France to Pacific countries, 72

Feathers, imports of, into Atlantic countries from: China, 229; Japan, 232

Fertilizers, imports of, into Atlantic countries from west coast of South America, 223, 224

Fiber products, imports of, into Atlantic countries from: Mexico, 220, 22I; Japan, 232; Philippine Islands, 239

Firearms. See Machinery and tools Firecrackers, imports of, into United States from China, 229

Fish, production of, in British Columbia, 6r; exports of, from United States to: west coast of South America, I76, China, I85186, Japan, 192, Philippine Islands, 209; from United States and
United Kingdom to Australasia, 201, 202; imports of, into United States from Japan, 232

Fish oil, exports of, into England from west coast of South America, 223

Flag, trade and the, $8,83,89-90$

Foodstuffs, imports of, into Pacific Ocean countries, 65-69; distribution of trade in, to Pacific countries, I33-r37, I52; analysis of trade of different Atlantic countries in: with Central America and

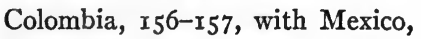
I66, with west coast of South America, 175-I77, with China, 185-r86, with Japan, I9I-I92, with Australasia, 20r-202, with Philippine Islands, 209-210; reasons for decreasing demand for, by Pacific countries, $245^{-246}$

Foreign exchange business of traders to Pacific countries, $80-82$

Forest products, exports of, from Pacific countries, 59-65. See Woods

France, exports of manufactured goods to Pacific countries by, $7 \mathrm{I}-$ 72 ; classes of manufactures exported by, 72; statistics as to trade of, with Pacific countries (I897I9II), IO2-I3I; share of, in exports of foodstuffs to Pacific countries, I33-I37; share in exports of clothing and clothing materials, $\mathrm{I}_{3} 8-\mathrm{I}_{4} 2$, I52; share in exports of general manufactures, I48-I50, I52; trade of, with Central America and Colombia, in: wines and spirits, 157, clothing and clothing materials, I59, iron and steel manufactures, 162 , miscellaneous manufactures, I64-I65; trade with 
Mexico, in: wines and spirits, 166 , boots and shoes, $167-168$, clothing and clothing materials, 167-169, miscellaneous manufactures, 174175; trade with west coast of South America in: wines and spirits, 176-177, clothing and clothing materials, 178-179, iron and steel manufactures, 179-180, miscellaneous manufactures, $181-$ 185; imports into, from: China, 229-231; Japan, 232-235

Freight accommodation for American shippers to Pacific countries, 86-87

Freights, local, effect of, on choice of ocean routes, $21-22$

Fruits, exports of, from United States to: Japan, 192, Australasia, 201, 202, Philippine Islands, 209; imports of, into Atlantic countries from: Central America and Colombia, 217,218 , west const of South America, 223, Japan, 232, Australia and New Zealand, 236

Fuel costs as a factor in choice of ocean routes, 19-20

Furniture, exports of, from United States to Mexico, 174 ; from United States and England to Australasia, 207, 208

Furs, imports of, into Atlantic countries from: China, 64, 229, 230; west coast of South America, 223; Japan, 232, 234

\section{G}

Gall apples, imports of, into Germany from China, 229

General structural material, items included under, 160; exports of, from Atlantic countries to: Cen- tral America and Colombia, $160-$ 163. Mexico, 170-171, west coast of South America, 179-180, China, 188, 189, Japan, 195-198, Australasia, 204-206, Philippine Islands, 211; exports from United States alone to Mexico, 172; exports from United States alone to west cosst of South America, 181; opportunity for development of American trade in, 248-249

Germany, export of manufactured goods to Pacific countries by, 71-72; classes of manufactures exported by, 72; position of, in regard to export of manufactures, as compared with United States, Fingland, and other countries, 75 fi.; stcamship service of, to Pacific countries, 85, 218-219; statistics as to trade of, with Pacific countries (1897-1911), 102131 ; share of, in exports of foodstuffs to Pacific countries, 133-137, 152 ; share in exports of clothing and clothing materials, 138-142, 152; share in exports of iron and steel manufactures, 144-148, 152 ; share in exports of general manufactures, 148-150, 152; details of trade of, with Central America and Colombia, in: foodstufis, 157 , clothing and clothing materials, 158-159, iron and steel manufactures, $161-163$, miscellaneous manufactures, 164-165; details of trade with Mexico in: foodstuffs, 166 , clothing and clothing materials, 167-169, iron and steel manufactures, 169-171, miscellaneous manufactures, 174-175; details of trade with west coast of South America in: foodstuffs, 177, cloth- 
ing and clothing materials, $178-$ I79, iron and steel manufactures, 179-180, miscellaneous manufactures, 18I-I85; details of trade with China in: foodstuffs, $185-186$, clothing and clothing materials, r87, iron and steel manufactures, I88, miscellaneous manufactures, r90-I9I; details of trade with Japan in: foodstuffs, 192, clothing and clothing materials, 192-r94, iron and steel manufactures, 195r98, miscellaneous manufactures, 199-200; details of trade with Australasia in: foodstuffs, 20I, clothing and clothing materials, 203-204, iron and steel manufactures, 204-206, miscellaneous manufactures, 207-209; details of trade with Philippine Islands in: foodstuffs, 209, clothing and clothing materials, 210-2II, iron and steel manufactures, 2Ir, miscellaneous manufactures, 212-213; imports into, from: Central America and Colombia, 217-219, Mexico, 220-222, west coast of South America, 223-228, China, 229-23I, Japan, 232-235, Australia and New Zealand, 236-238, Philippine Islands, 239

Ginger (preserved), imports of, into England from China, 229

Glass and glassware, exports of, from Atlantic countries to: Central America and Colombia, I64, I65; Mexico, I74; west coast of South America, I82, I83; China, I90, I9I; Japan, I99, 200; Australasia, 207, 208; Philippine Islands, 21 2, 213

Glucose, exports of, from United States to Australasia, $20 \mathrm{r}$
Gold, production of, by Pacific coast States, 6I; imports of, into Atlantic countries from: Central America and Colombia, 62, 217, Australia and New Zealand, 64, 236, Mexico, 62, 220, west coast of South America, 223, 225, China, 229, Japan, 232

Grains, production of, in British Colombia and Pacific States of United States, 6I; imports of, into Atlantic countries from Australia and New Zealand, 236

Guano, imports of, into Atlantic countries from west coast of South America, 223, 224

Guayaquil, choice of routes to, from Liverpool and from New York, 32, 34 ff., 255-262

Gums, imports of, into Atlantic countries from Australia and New Zealand, 236, 238

\section{H}

Haberdashery, exports of, from Atlantic countries to: west coast of South America, I78; Japan, I93; Australasia, 203

Hair, imports of, into England from China, 229; into United States from Japan, 232

Ham. See Provisions

Hardware. See General structural material

Hardwoods, exported from Central America, 62

Hats, exports of, from Atlantic countries to: west coast of South America, 178, Japan, I93, Australasia, 203, Philippine Islands, 210; imports of, into Atlantic countries from: Central America 
and Colombia, 217, 259, west coast of South America, 223, Japan, 232, 233

Hemp, export of, from Philippines, 65

Hennequin, export of, from Mexico, 62

Hides, imports of, into Atlantic countries from: Central America and Colombia, 62, 217, 218; Mexiico, 62, 220, 221; China, 64, 229, 231; Australia and New Zealand, 64, 236, 238; west coast of South America, 223; Japan, 232, 234

Honey, imports of, into Germany from west coast of South America, 223

Hongkong, choice of routes to, from Liverpool and from New York, 32, 34 ff., 255-262

Horns, imports of, into Germany from west coast of South America, 223

\section{I}

Imports, factors which determine character of demand for, 6 ; considerations influencing decision as to place of purchase, 6-8; choice of route for, 8-10; effect of density of population on, 48-52; effect of differing climatic conditions, 52-53; effect of presence of European populations, 53-55; effect of age of countries, 55-58; influence of a country's natural resources upon, 58-69; importance attached to question of origin of, 215-216; analysis of, from different Pacific countries, 217-240

India, import of raw cotton from, into Japan, 194

Iquique, choice of routes to, from
Liverpool and from New York, 32 fi., 255-262

Iron, advantage of United States, in production of, 78

Iron and steel manufactures, countries which export, to Pacific countries, 72-73; distribution of trade in, 143-148, 152; analysis of trade of different Atlantic countries in, with: Central America and Colombia, 160-163, Mexico, $170-173$, west coast of South America, 179-181, China, 188-189, Japan, 195-198, Australasia, 204206, Philippine Islands, 211; opportunity for development of American trade in, 248-250

Istle, imports of, into Atlantic countries from Mexico, 220

Italy, statistics as to trade of, with Pacific countries ( $1897-1911$ ), 102131

Ivory nuts, exported from Ecuador, 63

\section{J}

Jams, exports of, from England to: Central America and Colombia, 157; China, 185

Japan, extent of foreign trade of, 51 ; matters affecting foreign trade conditions in, 56-58; character and value of exports of, 39-60, 64; character and value of imports of, 66; countries with which chief trade exists, 70; distribution of import trade of, 85 ; statistics of trade between Atlantic countries and (1897-1911), 103-104, 114117 , 126; countries exporting food-

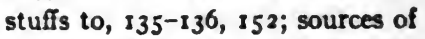
imports of clothing and clothing materials, 139-141, 152; exporta- 
tion of cotton from United States to, 143; sources of imports of iron and steel manufactures, $145-146$, I52; sources of imports of general manufactures, I49-150, 152; details of export trade of Atlantic countries with, in: foodstuffs, rgI192, clothing and clothing materials, I92-I94, iron and steel manufactures, I95-I98, miscellaneous manufactures, I99-200; import into, of raw cotton from India, I94; imports from China, I94; growth of shipyards in, shown by decreased sale of ships to, by England, I98; analysis of imports from, into Atlantic countries, 232235

Jewelry, exports of, from Atlantic countries to Mexico, I 74

Johnson, E. R., "Panama Canal Traffic and Tolls," cited, I6, 20, $27,43,45$

Jute piece goods, exports of, from England to west coast of South America, I82, I84

\section{$\mathbf{K}$}

Kauri gum, imports of, into Atlantic countries from New Zealand, 64, 236,238

\section{$\mathbf{L}$}

Lamps, chandeliers, etc., exports of, from United States to: west coast of South America, I82, 183; Australasia, 207, 208

Lard and lard products. See Provisions

Lead, production of, by Pacific Coast States, 6r; advantage to manufactures in United States from pro- duction of, 78; imports of, into Atlantic countries from: Mexico, 220, 22I; west coast of South America, 223, 226; Australia and New Zealand, 236

Lead manufactures, exports of, from Atlantic countries to: Mexico, I 74; west coast of South America, 182 , 183; China, r9o, I9r; Japan, 199, 200; Philippine Islands, 2I 2, 2 I3

Leather, exports of, from Australia and New Zealand, 64, 236, 238; imports of, into Japan, I93; imports of, into Germany from west coast of South America, 223

Leather manufactures, export trade of United States in, 73; exports of, from Atlantic countries to: west coast of South America, 182, I84, China, I90, I9I, Japan, I93, Australasia, 207, 208, Philippine Islands, 2IO, 2 II

Linen goods, exports of, from Atlantic countries to: west coast of South America, I78; Japan, I93; Australasia, 203; Philippine Islands, 2 ro

Liverpool, calculations concerning choice of routes from, to Pacific ports, 32-4I, 256, 258, 260, 262; changes effected in cost of service rates from, to Pacific ports, by Panama Canal, 36-39; advantages given to New York over, in point of time of delivery to Pacific ports by new route, $39-40$

Local freight and passenger business, effect of, on choice of ocean routes, 2I-22

Locomotives. See Railway materials

Lumber, production and export of, by Pacific countries, 59-65; expor- 
tation of, from New Zealand, 64; advantage of United States, in its resources for, for manufacturing purposes, 77-78; exportation of, from United States to Pacific countries, 143

\section{$\mathbf{M}$}

Machinery and tools, items included under, 160; exports of, from Atlantic countries to: Central America and Colombia, 160-163, Mexico, 170-171, west coast of South America, 179-180, China, 188, 189, Japan, 195-198, Australasia, 204-206, Philippine Islands, 211; exports from United States alone to Mexico, 272; exports from United States alone to west coast of South America, 181; opportunity for development of American trade in, 249-250

Mail service, lack of, from United States to Pacific countries, 86, 8788

Malt liquors, exports of, from Atlantic countries to: China, 885 , 186, Japan, 192; from United States to Philippine Islands, 209. See also Wines, spirits, and beer

Manganese, imports of, into Eng. land and Germany, from west coast of South America, 226

Manila, Philippine Islands, choice of routes to, from Liverpool and from New York, 32 ff., 255-262

Manila, imports of, into Atlantic countries from Philippinc Islands, 239

Manufactures, exports of, from $\mathrm{Pa}$ cific countries, $59-65$; imports of, into Pacific countries, 65-68; demand for, by Pacific countries, 68-
69; principal countries which export, to Pacific countries, $71-74$; position of different Atlantic countries in regard to coal, oil, and water power for, 76-77; advantages of United States in possession of raw materials for, $77-78$; relative position of United States, England, and continental countries in regard to exports of, $78 \mathrm{ff}$; list of, in which United States lcads the world, 78-79; distribution of trade in iron and steel, to Pacific countries, 143-148, 152; distribution of trade in general manufactures, 148-150, 152; analysis of trade of different Atlantic countries in miscellaneous, with: Central America and Colombia, 164-165, Mexico, 173-175, west coast of South America, 181-185, China, 189-191, Japan, 199-200, Australasia, 207-209, Philippine Islands, 212-214; opportunity for development of American trade in, 247-250

Marble and stone manufactures, exports of, from United States to Australasia, 207

Mats and matting, exports of, to Atlantic countries, from: Japan, 64, 232, 233; China, 229, 230, 23I Meat, exports of, from Australia, 64; exports of, from United States to: China, 185-186, Japan, 192; imports of, into England from west coast of South America, 223

Medicines and drugs, exports of, from Atlantic countries to: Central America and Colombia, 164, I65; Mexico, 174; west coast of South America, 182, 183; China, 190, 191; Japan, 199, 200; Aus- 
tralasia, 207, 208; Philippine Islands, $2 \mathrm{I} 2$

Melbourne, choice of routes to, from Liverpool and from New York, 32, 34 ff., 255-262

Mexico, per capita foreign trade of, 52 ; character and value of exports of, 59-60, 62; character and value of imports of, 66; statistics as to trade between Atlantic countries and (1897-I9II), I02-104, 106ro8, I23; countries exporting foodstuffs to, I34, I52; sources of imports of clothing and clothing materials, I38-I39, 'I52; sources of imports of iron and steel manufactures, I44-I45, I52; sources of imports of general manufactures, I49, 152; details of exports of different Atlantic countries to, in: foodstuffs, I66, clothing and clothing materials, $167-169$, iron and steel manufactures, I69-173, miscellaneous manufactures, I73175; analysis of imports from, into Atlantic countries, 220-222

Mineral oil, trade of United States in, to Pacific countries, I42-I43

Minerals, exports of, from Pacific countries, 59-65; advantage of United States in supply of, for manufacturing purposes, 78 ; imports of, into Atlantic countries from: Mexico, 220, 221, west coast of South America, 223, 224226, Australia and New Zealand, 236, 237

Miscellaneous iron and steel manufactures, items included under, I6I; exports of, from Atlantic countries to: Central America and Colombia, I6I-I62, Mexico, I70-I7I, west coast of South
America, I79-180, China, I88, I89, Japan, I95-I98, Australasia, 204206, Philippine Islands, 2II; exports from United States alone to Mexico, I72; exports from United States alone to west coast of South America, I8I

Musical instruments, exports of, from Atlantic countries to Mexico, I74; from United States and England to Australasia, 207, 208

\section{N}

Nails, spikes, etc. See General structural material

Natural gas, advantage of United States in possessing, for manufacturing purposes, 76-77

Natural resources, relation of a country's, to its trade, 58-69

Naval stores, exports of, from United States and England to Japan, I99

Netherlands, statistics as to trade of, with Pacific countries (I897I9II), IO2-I3I

New South Wales, population of, 50

New York, calculations concerning choice of routes from, to Pacific ports, 32-4I, 255-262; changes effected by Panama Canal in cost of service rates to Pacific ports from, 36-39; effect of new route on time of delivery to Pacific ports from, 39-40

New Zealand, density of population in, 50-5I; per capita foreign trade of, 52; character and value of exports of, $59-60,63,64$; character and value of imports of, 66; countries with which chief trade takes place, 70; distribution of 
import trade of, 85; clothing and clothing material imported chiefly from England, 14I, 152. See Australasia

Nickel, imports of, into Germany from Japan, 232

Nitrate, exportation of, from Chile, $63,223,224$

Nuts, exports of, from United States to Japan, 192; imports of, into United States from: Philippine Islands, 209, west coast of South America, 223, Japan, 232

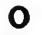

Oil, exports of, from United States to Pacific countries, 73, 142-143; as a factor in considering manufacturing possibilities of different countries, 76-77. See Petroleum

Oilcloth, exports of, from England to Australasia, 207

Oil-seed cake, imports of, into England from Mexico, 220, 222

Oil sceds, imports of, into Atlantic countries from China, 229

Oleo and oleomargarine, imports of, into England from Australia and New Zealand, 236

Operating expenses of steamers, a chief determinant in choice of ocean routes, 23-25; estimates and comparisons of, by different routes, 25-45, 255-262

Opium, imports of, into United States from China, 229

Origin of imports, considerations determining, 6-8

\section{$\mathbf{P}$}

Pacific States of United States, per capita external trade of, 52; character and value of export trade of,
60, 6r-62, 130; exportation of lumber from, $x 43$

Paints, exports of, from Athutic countries to: Central America and Colombia, 164, 165; Mexico, 174; west coast of South America, 182, 184; China, 190, 191; Japan, 199, 200; Australasia, 207, 208; Philippine Islands, 212, 213

Panama Canal, toll changes in, 20

Panama hats, imports of, into United States and England from Central America and Colombia, 219

Panama Railroad, a negligible quantity in considering trade routes, 41 Panama route, comparison of advantages of, with other all-sea routes, between Liverpool and New York and Pacific ports, 30-41, 255-262; overland and land-and-sea routes compared with, 4t-45; influence of, on trade between United States and countries on west coast of South America, 100-101, 106, 109, III, I 2I; effect on trade of United States with Central America, Colombia, and Mexico, 106, 108, 121; effect on trade with China, 114, 121 ; benefits of, to trade with Japan, 114, 117, 121; effect on American trade with Pacific countries in miscellaneous manufactures, 284

Paper and paper manufactures, exports of, from Atlantic countries to: Central America and Colombia, 164, 165, Mexico, 174, 175, west coast of South America, 182, 183 , China, 190, Japan, 199, 200, Australasia, 207, 208, Philippine Islands, 212; imports of, into Atlantic countries from Japan, 232 
Passengers, local, influence of, on choice of ocean routes, $2 \mathrm{I}-22$

Passenger service, lack of, from United States to Pacific countries, $86,87-88$

Peanuts, imports of, into Germany from China, 229

Peas, imports of, into England from: China, 229; Australia and New Zealand, 236

Perfumery, exports of, from Atlantic countries to: west coast of South America, 182, I83; China, r9o; Philippine Islands, 21 2. See also Soap

Peru, extent of foreign trade of, 52; character and value of exports of, 59-6o, 63; character and value of imports of, 66. See West coast of South America

Petroleum oil, production of, by Pacific Coast States, 6r; imports of, into England from: Mexico, 220, Australia and New Zealand, 236

Philippine Islands, character and value of exports of, 59-6o, 64-65; character and value of imports of, 66; statistics of trade between Atlantic countries and ( $1897^{-}$ I9II), I03-I04, II9-I2I, I 28; kind of foodstuffs imported by, and source of supply, r37; sources of imports of clothing and clothing material, $\mathrm{I}_{4} \mathrm{I}-\mathrm{r} 42, \mathrm{I}_{5}$; sources of imports of iron and steel manufactures, 147,152 ; sources of imports of general manufactures, 148-I49, I52; details of export trade of different Atlantic countries with, in: foodstuffs, 209-2ro, clothing and clothing materials, 2IO-2II, iron and steel manufac- tures, 2 I r, miscellaneous manufactures, 21 2-214; analysis of imports from, into Atlantic countries, 239240

Phormium, an export of New Zealand, 64

Pianos, export of, from Spain to Philippine Islands, 2 I 2

Pickles, exports of, from United Kingdom to: Australasia, 20I, 202; Philippine Islands, 209

Pig iron, output of United States in, 78 ; imports of, into United States from China, 229; into Japan from China, 23I

Pipes and fittings. See General structural material

Plants, imports of, into Atlantic countries from Japan, 232

Plate and plated ware, exports of, from England to Australasia, 207

Population, relation between density of, and commercial activity, 48-52 Porcelain, exports of, from Germany to China, rgo, rgr

Precious stones, imports of, into Atlantic countries from: Central America and Colombia, 217; Australasia, 236

Preserves, exports of, from Atlantic countries to Central America and Colombia, 157

Price as a factor in determining origin of imports, 7-8

Printing paper, exports of, from Atlantic countries to Australasia, 207, 208

Printing presses. See Machinery and tools

Provisions, exports of, from United States to: Central America and Colombia, 156, Mexico, r66, west coast of South America, I75-I76, 
Philippine Islands, 209; from United States and United Kingdom to Australasia, 201, 202

Pumps. See Machinery and tools

\section{Q}

Queensland, density of population of, 50

Quictsilver, production of, by $\mathrm{Pa}$ cific Coast States, 6r

\section{$\mathbf{R}$}

Racial prejudices, bearing of, on international trade, 8

Railway material, items included under, 160; exports of, from Atlantic countries to: Central America and Colombia, 160-163, Mexico, 170-171, west coast of South America, 179-180, China, 188, 189, Japan, 195-198, Australasia, 204-206, Philippine Islands, 211; exports from United States alone to Mexico, 172; exports from United States alone to west coast of South America, 181 ; opportunity for development of American trade in, 249-250

Railways, trans-continental, considered as competitors of Panama route, 42-45

Ready-made clothing, exports of, from Atlantic countries to: Central America and Colombia, 159160; Mexico, 169

Resident agents of foreign business houses trading with Pacific countries, 94-95

Return cargoes, importance of, 227 , 228

Rice, imports of, into Atlantic coun- tries from: Japan, 64, 232, 233; Mexico, 220, 221-222; China, 229 Rice and rice starch, exports of, from Germany to west coast of South America, 177

Rice Alour, imports of, into United States from: China, 229; Japen, 232, 233

Routes, matters which affect choice of, in international trade, 8-10, 61-23; calculations as to choice of, via Suez, Cape of Good Hope, Straits of Magellan, or Panama, 26-41, 255-262

Rubber, imports of, into Atlantic countries from: Mexico, 62, 220, 221; Central America and Colombia, 62, 63, 217, 218; west coast of South America, 63, 223, 226

Rubber manufactures, exports of, from Atlantic countries to: Central America and Colombia, 164, 165; Mexico, 174; west coast of South America, 182, 183; China, 190, 191; Japan, 199, 200; Australasia, 207, 208; Philippine Islands, 212, 213

Russia, exports from, to China (1897-1911), 112-113; notable rise of, as an exporter, 113

$\mathbf{S}$

Salt, exports of, from United Kingdom to Australasia, 201

San Francisco, choice of routes to, from Liverpool and from New York, 32 ff., 255-262

San Jose de Guatemala, choice of routes to, from Liverpool and from New York, 32 ff., 255-262

Scales. Sce Machinery and tools

Scientific instruments, exports of, 
from Atlantic countries to: west coast of South America, I82, 183; China, rgo; Japan, r99, 200; Australasia, 207, 208; Philippine Islands, 212

Seattle, choice of routes to, from Liverpool and from New York, 32 ff., 255-262

Seed cake, imports of, into England from west coast of South America, 223

Seed oil, export of, from England to west coast of South America, 182, 185

Seeds, imports of, into England from west coast of South America, 223

Sentiment, effect of, in determining direction of trade, 8

Sesame seeds, exportation of, from China, 64

Sewing machines. See Machinery and tools

Shanghai, choice of routes to, from Liverpool and from New York, 32, 34 ff., 255-262

Shells, imports of, into England from: west coast of South America, 223; Australia and New Zealand, 236

Shipping, lack of American, and question of disadvantages arising from, 83-90, 218-219

Ships, exports of, from England to China, rgo; decreased sale of, by England to Japan, 198

Shoe leather, exports of, from United States to Central America and Colombia, $157,{ }_{5} 8$

Shoe machinery. See Machinery and tools

Silk, routes for transportation of, 43-44; imports of raw, into Atlantic countries from: China, 64, 229, Japan, 64, 232, 233; imports of manufactured, into Atlantic countries from: China, 229, Japan, 232, 233

Silk manufactures, in United States as compared with England, Germany, and France, 78; exports of, from Atlantic countries to: Central America and Colombia, 157, 158, I59, Mexico, 167, I68, 169, west coast of South America, I78, China, 187, Japan, 193, Australasia, 203, 204, Philippine Islands, 2IO, 2 II

Silver, production of, by Pacific Coast States, 6r; imports of, into Atlantic countries from: Central America and Colombia, 62, 217, Mexico, 62, 220, west coast of South America, 223, 225, China, 229, Japan, 232, Australia and New Zealand, 236

Singapore, choice of routes to, from Liverpool and from New York, 32 ff., $255^{-262}$

Sisal, imports of, into Atlantic countries from Mexico, 220, 221

Skins, exports of, from: Central America and Colombia, 62, 63; Australia and New Zealand, 64, 236, 238; China, 64, 229, 23I; west coast of South America, 223

Soap, exports of, from Atlantic countries to: Central America and Colombia, I64, I65; west coast of South America, I82, I83; China, I9O, I9I; Japan, I99, 200; Australasia, 207, 208; Philippine Islands, $2 \mathrm{I} 2$

"Sole agency" plan employed by business houses trading with $\mathrm{Pa}$ cific countries, 94-95

South Australia, population of, 50

Soya beans, imports of, into Atlantic 
countries from: China, 229; Japan, 232

Spain, statistics as to trade of, with Pacific countrics ( $1897-1911$ ), 102131 ; details of trade with Philippine Islands in: foodstuffs, $200-210$, clothing and clothing materials, $210-211$, miscellaneous manufactures, 21 2-213; decline of trade of, with Philippine Islands, 213

Spices, imports of, into United States from China, 229; into Atlantic countrics from Japan, 232

Spirits. See Wine, spirits, and beer

Stationery, exports of, from England to: west coast of South America, 182, 185; Australasia, 207

Stcamers, disadvantages to United States resulting from lack of service to Pacific countries by American, 83-90, 218-219

Storms, influence of, on choice of occan routes, 22-23

Straw braid, imports of, into Atlantic countries from: China, 64, 229, 230, 231; Japan, 64, 232, 233

Structural and industrial materials, imports of, into Pacific Ocean countries, $65-69$

Suez Canal, toll charges in, 20

Suez route, comparison of, with other all-sea routes, 15-41, 255-262

Sugar, exports of unrefined, from: Peru, 63, Philippine Islands, 65, 239, Central America and Colombia, 217, 218, Mexico, 220, west coast of South America, 223, 226; exports of refined, from Atlantic countries to: Central America and Colombia, 156, 157, west coast of South America, 177, Japan, 192

Sulphur, imports of, into United States from Japan, 232
Sydney, choice of routes to, from Liverpool and from New York, 32, 34 ff., $255-262$

\section{$\mathbf{T}$}

Tallow, exportation of, from Aus tralia, 64

Tan bark, imports of, into England from Australasia, 236

Tarif, cffect of reduction of, upon need of United States manufacturers for a foreign market, 79-80

Tasmania, population of, 50

Tea, imports of, into Atlantic countries from: China, 64, 229, Japan, 64, 232, 233, 235

Tchuantepec Railway, a negligible quantity in considering trade routes, $41-42$

Telegraph and telephone apparatus, exports of, from England to: China, 190; Japan, 199, 200; Philippine Islands, 212

Textile fibers, export of, from Mexico, 62

Textile manufactures, exportation of, from Japan, 64; imports of, into Pacific countries, 65-69; countries which export, to Pacific countries, 72

Tin, exportation of, from Bolivia, 63; imports of, into Atlantic countries from: west coast of South America, 223, 225, China, 229, 231, Australasia, 236

Tin manufactures, exports of, from Atlantic countries to: Merico, 174, 175; west coast of South America, 182, 183; China, 190, 191; Japan, 199, 200; Australasia, 207, 208; Philippine Islands, 212, 213 
Tobacco, imports of, into Atlantic countries from Philippine Islands, 65, 239; exports of, from United States to Australasia, 20I, 202

Tobacco manufactures, exports of, from Atlantic countries to: west coast of South America, I76, I77, China, I85, I86, Japan, I92; from United States and United Kingdom to Australasia, 201, 202; imports of, into Atlantic countries from Philippine Islands, 239

Toll charges in canals, and their influence upon choice of ocean routes, 20-2I

Toys, imports of, into United States and England from Japan, 232

Trade, international, factors which determine character of, in different countries, 6; considerations influencing direction of, 6-8; choice of route, 8-ro; effect of density of population on, 48-52; relation between climatic conditions and, 5253; stimulating effect of European populations on, 53-55; relation between age of countries and, 5558 ; relation between natural resources of countries and, 5869

Trade routes, factors influencing choice of, $17-23$; statistics concerning, 24-25, 255-262

Tramp steamers, proportion of ocean freights carried by, 25

Trans-Andine Railway, 4I

Transportation facilities, influence on American trade of lack of, $83-90$

Turpentine, exports of, from United States to Australasia, 207, 208

Typewriters. See Machinery and tools
ర

Umbrellas, exports of, from England to China, rgo

United Kingdom, figures as to trade of, with Pacific countries (I897I9Ir), 102-13r. See England

United States, export of manufactured goods to Pacific countries by, $7 \mathrm{I}-72$; classes of manufactures exported by, 72-73; position of, in regard to exports of manufactures, $73 \mathrm{ff}$.; advantageous position of, in regard to coal, 76-77; advantages of, in possessing raw materials for manufactures, $77-78$; manufactures in which world leadership is held by, 78-79; new conditions in, pointing to desirability of a foreign market, 79-80; lack of banks of, in Pacific countries, and comparative disadvantages, 80-83; disadvantages to, from lack of shipping, 83-90; question as to inferiority of methods employed by American exporters, 90-97; figures as to trade of, with Pacific countries (I897-I9II), I02-I3I; share of, in exports of foodstuffs to Pacific countries, $133-137,152$; share in exports of clothing and clothing materials, $\mathrm{I}_{37}-\mathrm{I}_{4} 2, \mathrm{I}_{52}$; share in exports of iron and steel manufactures, I44-I48, $\mathrm{I}_{52}$; share in exports of general manufactures, I48-150, I52; details of trade of, with Central America and Colombia in: foodstuffs, 156 , clothing and clothing materials, ${ }_{57}-I_{5} 8$, iron and steel manufactures, $160-$ I6r, I62, miscellaneous manufactures, $163-165$; details of trade 
with Mexico in: foodstuffs, 166, clothing and clothing materials, 167-169, iron and steel manufactures, 169-173, miscellaneous manufactures, 173-175; details of trade with west coast of South America in: foodstuffs, 175-177, clothing and clothing matcrials, 178-179, iron and steel manufactures, 179-181, miscellancous manufactures, 181-185; details of trade with China in: foodstuffs, $185^{-186}$, clothing and clothing materials, 187, iron and steel manufactures, 188-189, miscellaneous manufactures, 189-191; details of trade with Japan in: foodstuffs, $191-19^{2}$, clothing and clothing matcrials, 192-194, iron and steel manufactures, 195-198, miscellaneous manufactures, 199200 ; details of trade with Australasia in: foodstufis, 201-202, clothing and clothing materials, 203-204, iron and stecl manufactures, 204-206, miscellancous manufactures, 207-200; details of trade with Philippine Islands in: foodstuffs, 200-210, clothing and clothing materials, $210-2 x 1$, iron and steel manufactures, 211 , miscellaneous manufactures, $212-213$; imports into, from: Central America and Colombia, 217-219, Mexico, 220-222, west coast of South America, 223-228, China, 229-232, Japan, 232-235, Australia and New Zealand, 236-238, Philippine Islands, 239-240; opportunities open to, in Pacific countries, $242-$ 250 ; chief points to be borne in mind by manufacturers of, 250 251
Valparaiso, choice of routes to, from Liverpool and from New York, 32, 34 ff., 255-262

Vanilla, imports of, into United States from Mexico, 220,222

Vegetable fibers, imports of, into Atlantic countries from: Mexico, 220, 221; Philippine Islands, 239

Vegetable ivory, imports of, into Atlantic countries from Central America and Colombia, 217, 219; into United States from west coast of South America, 223, 226, 227

Vegetable oils, imports of, into Atlantic countries from: China, 64, 229; Japan, 232

Vegetables, exports of, from United States to: Japan, 192, Philippine Islands, 209; imports of, into United States from China, 229; imports into United States and England from Japan, 232

"Vetements," exports of, from France to Central America and Colombia, 159

Victoria, state of, population of, 50

\section{W}

Water power, position of different countries in regard to, for manufacturing purposes, 76-77

Wax, imports of, into England from west coast of South America, 223

Wellington, choice of routes to, from Liverpool and from New York, 32, 33, 34 ff., 255-262

West coast of South America (Ecuador, Peru, Bolivia, and Chile), statistics of trade between Atlantic countries and (1897-1911), 
I03-rO4, ro9-IIr, I24; countries exporting foodstuffs to, $\mathrm{I}_{34}-\mathrm{I} 35$, 152; sources of imports of clothing and clothing materials, $139,1_{52}$; sources of imports of iron and steel manufactures, I45, I52; sources of imports of general manufactures, $148-149,152$; details of export trade of different Atlantic countries with, in: foodstuffs, $175^{-1} 77$, clothing and clothing materials, 178-179, iron and steel manufactures, I79-r8I, miscellaneous manufactures, $18 \mathrm{r}-\mathrm{r} 85$; analysis of imports from, into Atlantic countries, $223-228$

Wheat, exportation of, from British Colombia and Pacific States of United States, 6r; from Australia, 63-54. See Breadstuffs

Wheat flour, exports of, from United

States to Central America and Colombia, 156; imports of, into England from Australia and New Zealand, 236

Windmills. See Machinery and tools Wines, spirits, and beer, exports of, from Atlantic countries to: Central America and Colombia, ${ }_{55} 6$, 157, Mexico, r66, west coast of South America, 176, 177, China, I85, I86, Japan, I92, Australasia, 201, 202, Philippine Islands, 209; imports from: Japan, 232, Australia and New Zealand, 236

Wire. See General structural material

Wood manufactures, exportation of, by United States to Pacific countries, 73; exports of, from Atlantic countries to: west coast of South America, I82, 184, China, 190, I91, Japan, 199, 200, Australasia, 207,
208, Philippine Islands, 212; imports of, into Atlantic countries from Japan, 232, 233

Wood oil, imports of, into Atlantic countries from China, 229, 23 I

Woods, imports of, into Atlantic countries from: Central America and Colombia, 217, 219; Mexico, 220, 222; Australia and New Zealand, 236

Wool, production of, by Pacific Coast States of United States, 6r; exportation of, from Peru, 63 ; from Australia, 63, 64; advantage of United States in production of, for manufacturing purposes, 77; imports of, into Atlantic countries from: west coast of South America, 223, 227, China, 229, 231, Australia and New Zealand, 236, 237-238 Woolen goods, exports of, from Atlantic countries to: Central America and Colombia, 157, 158, 159; Mexico, 167, I68, 169; west coast of South America, I78, I79; China, I87; Japan, r93; Australasia, 203, 204; Philippine Islands, 2ro

\section{$Y$}

Yokohoma, choice of routes to, from Liverpool and from New York, 32, 34 ff., $255^{-262}$

\section{Z}

Zinc, advantage to manufactures in United States from home production of, 78 ; imports of, into United States from Mexico, 220, $22 \mathrm{I}$

Zinc manufactures, exports of, from Germany to: west coast of South America, 182; China, I9o, I9I; Japan, I99, 200; Philippine Islands, 212, 213 



\title{
Panama : the Canal, the Country and the People
}

\author{
Now, Revised and Enlarged Edition \\ By Arthur Bullard \\ (ALBERT EDWARDS)
}

Decorated Cloth, Illustrated, 8vo, \$2.00 net; postage extra

Not only has Mr. Bullard revised such material of the first edition of his book as has been retained in the present issue, but he has added to that two new chapters. These have to do largely with the canal since its completion. This work has probably enjoyed greater popularity than any other volume on Panama, a fact due, no doubt, to its comprehensiveness. It is not confined to any one matter. There are descriptions of the natural beauties of the locality, discussions of the customs and life of its inhabitants; and sections devoted to the canal, its history, construction and those concerned with it. Besides the new text there are also many new and fascinating illustrations.

"A thoroughly satisfactory book for one who is looking for solid information." - Boston Globe.

"A most interesting picture of the country as it is today." -San Francisco Chronicle.

"One of the very few books on any Latin-American country that gives any idea of the whole land and people."

-Los Angeles Times.

"One of the very best of travel books." - Continent.

"Lively and readable, containing the real atmosphere of the tropics." - Minneapolis Tribune.

"A book which every American ought to read, both for pleasure and profit."

-New York Herald.

\section{THE MACMILLAN COMPANY}

\section{Publishers 64-66 Fifth Avenue New York}




\title{
Artificial Waterways of the World
}

\author{
Bx A. Barton HepburN \\ Author of "History of Coinage and Currency" \\ Cloth, Illustrated, $12 \mathrm{mo}$, \$1.25 net; postage extra \\ Now and Rovised Edition
}

This book which contains in concise form the salient facts as to artificial waterways and their relation to commercial development opens with a general consideration of the importance of canals as factors in the natural development and substantial progress of a country and then proceeds to a discussion of the canals of Holland, Belgium, France, Germany, Great Britain, Denmark, Russia, Austria-Hungary, Sweden, Italy, Spain, India and China. The Author follows this with the details in the history of the canal system of New York. He then turns to the Panama Canal and finally to other great American canals - Ambrose Channel, The Cape Cod Canal, Sault Ste. Marie and the various Canadian canals. Preceding the appendix, which is made up of some fifteen tables giving statistics bearing on the subject of canals, is a chapter on the waterways question and the conservation of our resources. Altogether Mr. Hepburn's work is one of the most practical and concise treatments of the entire subject of canals that has been published.

\section{Intemational Trade and Exchange:}

$A$ Study of the Mechanism and Advantages of Commerce BY HARRY GUNNISON BROWN, of Yale University Cloth, $12 \mathrm{mo}, 81.50$ nes

The theory of international and intranational trade with reference to the exchange mechanism and to the effects of government interferences are here covered. The work is divided into two main parts, in the first of which the author deals chiefly with Foreign Exchange, though there are two introductory chapters on Laws of Money and The Nature of Banking. The succeeding chapters of this part take up The Nature and Method of Foreign Exchange, The Rate of Exchange and The Rate of Exchange and the Flow of Specie. Part II begins with a consideration of the gains of trade, turns to the conditions determining the share which each of two or more countries gets from trade between them, and finally discusses such topics as Revenue Tariffs, Protective Tariffs, Bounties, Navigation Acts, Government Construction of Canals for the Free Use of Commercial Interests and Land Grants in Encouragement of Railroad Building.

THE MACMILLAN COMPANY

Publishers

64-66 Fifth Arenue

New York 


\title{
International Commercial Polícies
}

\section{With Special Reference to the United States}

\section{By Dr. GEORGE WYGATT FISK}

\author{
Cloth, $x v i+288$ pp., bibliography, index. 12mo, \$1.25 net
}

\section{SYNOPSIS OF CONTENTS}

I. Introduction - Definition of Terms, Scope, etc.

II. Development of Modern Commercial Politics: The Mercantile System.

III. Development of Modern Commercial Politics: Free Trade.

IV. Development of Modern Commercial Politics: Protection.

v. Customs - General: Import Duties.

VI. Customs - Export and Transit Duties: Prohibition.

VII. Customs - Tariffs and Tariff System.

VIII. Customs - Ad Valorem, Specific and Differential Duties.

IX. Customs - Administrative Institutions.
X. Customs - Internal Taxation: Export and Import Favors.

XI. Commercial Treaties - Their Nature, Form and Contents.

XII. Commercial Treaties - Reciprocity and the Most Favored Nation Clause.

XIII. Public Trade-Promoting Institutions.

XIV. Public Trade-Promoting Institutions (continued).

XV. Quasi-Public and Private TradePromoting Institutions.

XVI. Commercial Statistics: Balance of Trade and Foreign Exchange. XVII. Navigation Politics.

XVIII. Public Navigation-Promoting Institutions.

"It is a treatise likely to be of the utmost interest and value to every man engaged, or about to engage, in commercial pursuits, or desirous of informing himself as to the laws and principles upon which commerce is based."

- Moody's Magazine.

"This volume covers the whole range of tariffs, customs, reciprocity, trade promotion, and navigation. The material is based upon a wholly new plan, which has special reference to the needs of the student and the general reader."

- Review of Reviews.

"Will prove stimulating to college students taking courses in commerce or economics." - The Independent.

"It brings together all the various theories of international trade, and so presents to the reader matter which otherwise he would be compelled to seek in a number of volumes."- Journal of Commerce.

". . Presents a comprehensive and very interesting exposition of the evolution, from its earliest stages, of international commercial policy, and points out ably, with reference especially to the United States, its present general trend." 


\section{The Theory of International Trade}

With Some of Its Applications to Economic Policy

By C. F. Bastable, M.A., LL.D.

Professor of Political Economy in the University of Dublin.

Published in London, 1897. Fourth edition, 1903.

Cloth, 197 \$P., $12 \mathrm{mo}, \$ 1.25$ net

A restatement, in a more complete form, of the doctrines of the classical English school on this important and timely subject.

\section{The Tariff in Our Times}

A Study of Fifty Years' Experience with the Doctrines of Protection

By IDA M. TARBELL

r2mo, s1, so net; postage extra

"There is scarcely a great cvent or a public man of importance in the period covered that does not figure directly or indirectly in this story. The result is a narrative full of dramatic situations, big movements, strenuous fighting, and fine characters."

- Philadelphia Worth American.

"An interesting and exhaustive treatise of the subject of tariff and tariff making." - American Banker.

". . No single volume has brought out the facts and interests connected with tariff and tariff tinkering as does this book in which the story is told in narrative form." - Boston Transcript.

"Miss Tarbell has written a book of high value and great timeliness, in her history of the tariff. . . . Every thoughtful student of the subject should read Miss Tarbell's book, whether he believes in tariff for revenue only, high protection, or free trade."

- Wall Street Journal.

\section{THE MACMILLAN COMPANY}

Probliabers 


\title{
American Railroad Economics :
}

A Textbook for Investors and Students

\author{
By A. M. SAKOLSKI, Pн.D. \\ LECTURER IN NEW YORK UNIVERSITY, SCHOOL OF COMMERCE, \\ FINANCE AND ACCOUNTS
}

Cloth, I2mo, \$1.25 net

The railroads are studied as business enterprises. Their operations and activities are analyzed and interpreted from an economic and financial viewpoint, and on the basis of actual conditions. The book, therefore, contains the latest legal, statistical, and accounting data relating to American railroads.

Among the topics discussed are :

(I) Rates and Rate Regulation.

(2) Railroad Securities.

(3) Railroad System Expansion and Unification.

(4) The Physical Factors in Economic Operation.

(5) Traffic Statistics and Standards for Gauging Operating Economy and Efficiency.

(6) Accounting Problems and the Analysis of Financial Statements, and

(7) Capitalization and Capital Investment.

\section{THE MACMILLAN COMPANY}

Publishers

64-66 Fifth Avenue

New York 


\title{
Sea Insurance According to British Statute
}

By WLLIAM GOW, M.A., Ph.D.

\author{
Author of "Marine Insurance" \\ Clock, 8425 met; postege extre
}

\section{RROM TER PREFACE}

The passing of the Marine Insurance Act of 1906 (6 Edw. VII. Ch. 4r) was the commencement of a new era in the law and practice of Marine Insurance in Britain. . . . It has therefore appeared to the writer that in the present state of opinion the most useful kind of guide to the law and practice of Marine Insurance would be a detailed statement of the provisions of the Marine Insurance Act with a supplement consisting of the essential parts of the leading judgments upon which the Act has confessedly been constructed. It is thought that such a supplement may be of value, not only historically, but as affording an explanation of points in the Act which may in the course of years become less clear than they were to the framers of the Bill and to the various authorities and bodies to whom it was submitted before it assumed its final form.

\section{CONTENTS}

MARINE INSURANCE ACT, IgO6.

Marine insurance (Gambling Policies) ACt, igog.

HistoriCAL SKETCH.

COMMENTARY ON THE MARINE INSURANCE ACT, Ig06.

Note on tue Marine insurance (Gambling Policies) ACt, 1909. Alphabetical list of leading Casfs.

Curonological list of leading Cases.

SUBject List OF LeadiNg CASES.

INDEX OF CASES CITED IN THE COMMENTARY.

INDEX OF EXTRACTS FROM JUDGMRNTS IN LEADING CASES ON MARINE INSURANCE.

EXTRACTS FROM JUDGMENTS IN LRADING CASES.

SUPPLEMENTARY EXTRACTS FROM JUDGMENTS IN LENING CASES on General Averagr.

GENERAL INDEX.

THE MACMILLAN COMPANY

Publinbers 64-66 Fifth Avenue Tev Yort: 



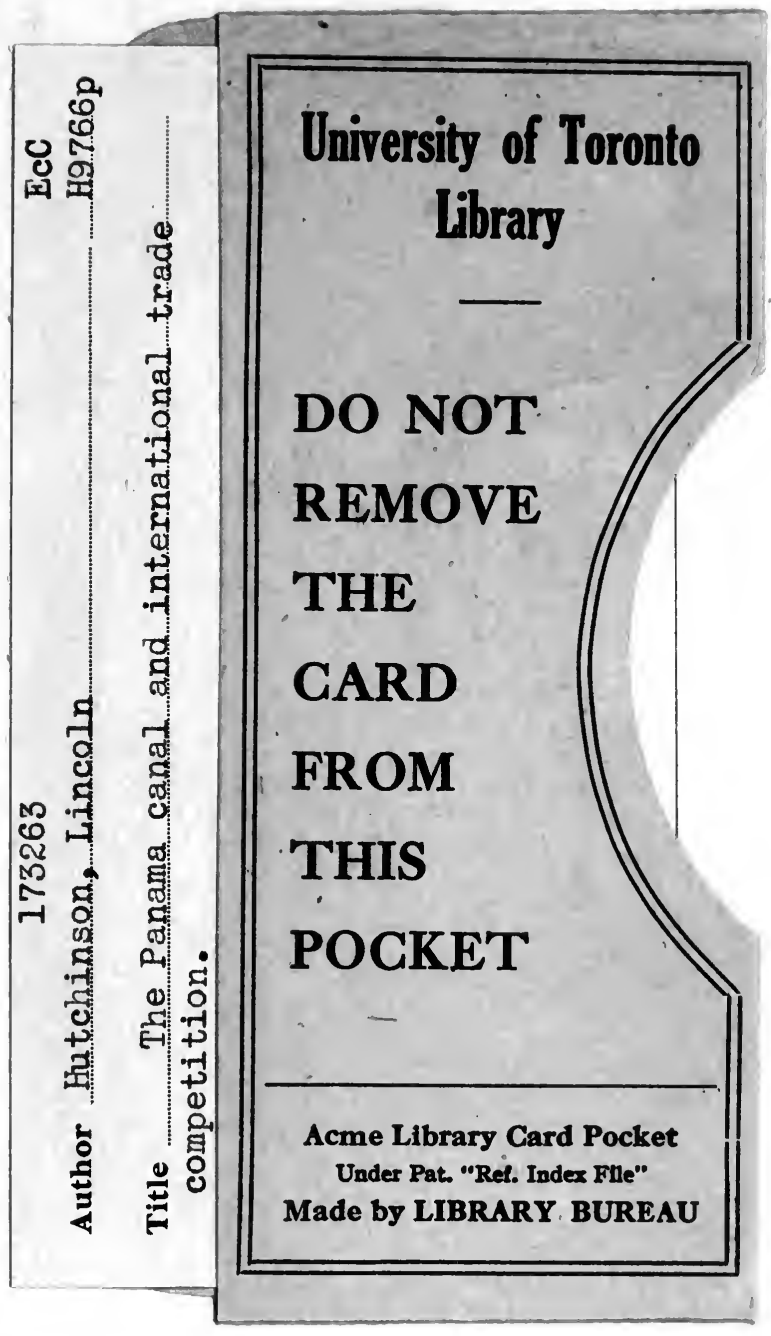


